U. S. DEPARTMENT OF COMMERCE BUREAU OF STANDARDS

\title{
REPORT OF THE TWENTY-THIRD NATIONAL CONFERENCE ON WEIGHTS AND MEASURES
}

ATTENDED BY REPRESENTATIVES FROM VARIOUS STATES

HELD AT THE BUREAU OF STANDARDS WASHINGTON, D. C., JUNE 3,4, 5, AND 6, 1930 


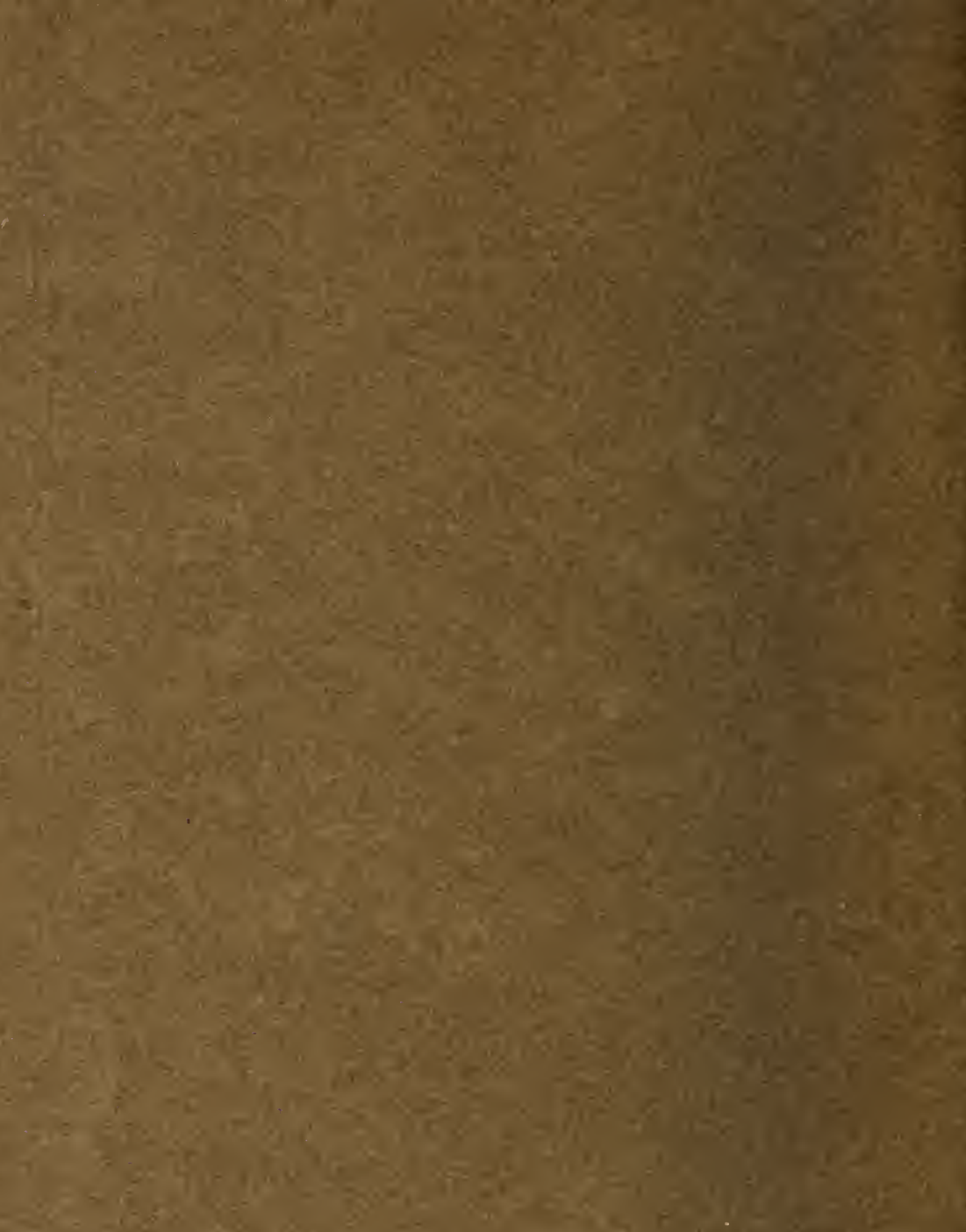

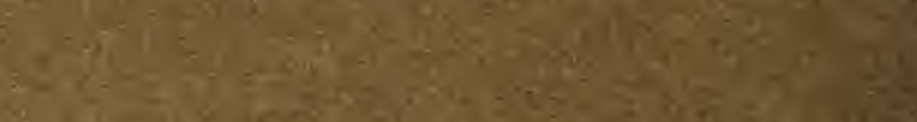

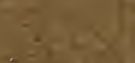

s

$x^{2}+2=0$ 


\section{U. S. DEPARTMENT OF COMMERCE}

\section{R. P. LAMONT, Secretary}

BUREAU OF STANDARDS

GEORGE K. BURGESS, Director

MISCELLANEOUS PUBLICATIONS-No. 116

\section{REPORT OF THE TWENTY-THIRD NATIONAL CONFERENCE}

ON

\section{WEIGHTS AND MEASURES}

\section{ATTENDED BY REPRESENTATIVES}

FROM VARIOUS STATES

HELD AT THE BUREAU OF STANDARDS

WASHINGTON, D. C., JUNE 3, 4, 5, and 6, 1930

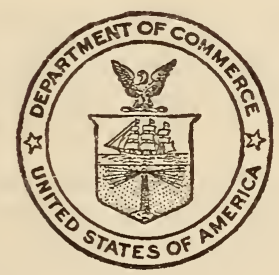

UNITED STATES

GOVERNMENT PRINTING OFFICE

WASHINGTON : 1931 



\section{OFFICERS AND COIMMITTEES}

\section{OFFICERS}

Honorary president, SAMuEl W. Stratton, chairman of the executive committee, Massachusetts Institute of Technology, Cambridge, Mass., and former Director of the Bureau of Standards, Washington, D. C.

(Serving during twenty-third national conference)

President, George K. Burgess, Director, Bureau of Standards, Washington, D. C. First vice president, FrANCIS MEREDITH, director, State division of standards, Boston, Mass.

Second vice president, HowARD S. JARRETT, State commissioner of weights and measures, Charleston, W. Va.

Secretary, F. S. Holprook, Bureau of Standards, Washington, D. C.

Treasurer, GEorge F. Austin, sealer of weights and measures, Detroit, Mich.

(As elected by twenty-third national conference for the ensuing year)

President, George K. Burgess, Director, Bureau of Standards, Washington, D. C. First vice president, HoWARD S. JARRETT, State commissioner of weights and measures, Charleston, W. Va.

Second vice president, ALBERT B. SмIтH, director, State bureau of standard weights and measures, Harrisburg, Pa.

Secretary, F. S. Holвrook, Bureau of Standards, Washington, D. C.

Treasurer, GEonge F. Austin, Jr., assistant supervisor, bureau of weights and measures, Detroit, Mich."

\section{COMMITTEES}

\section{EXECUTIVE COMMITTEE}

(As elected by twenty-third national conference)

Ghorge K. Burgess

HOWARD S. JARRETT

ALBERT B. SMITH

F. S. HOLBROOK

Ex officio.

GEORGE F. Austin, Jr.

WILLIAM F. CLUETT, chief deputy inspector of weights and measures, Chicago, Ill.

E. J. Crouch, director, State bureau of weights and measures, Boise, Idaho.

H. N. Davis, deputy State commissioner of weights and measures, Montpelier, Vt.

C. V. FicketT, sealer of weights and measures, Portland, Me.

Thomas Flaherty, city and county sealer of weights and measures, San Francisco, Calif.

J. HARRY Foley, State superintendent of weights and measures, Trenton, N. J.

William Foster, sealer of weights and measures, Springfleld, Mass.

William A. Graham, State commissioner of agriculture, Raleigh, N. C.

S. T. GRIFFITH, chief, division of weights and measures, Baltimore, Md.

T. F. MAHoNeY, sealer of weights and measures, Chattanooga, Tenn.

EDWARD J. MaroNeY, sealer of weights and measures, New Haven, Conn.

I. L. MLLER, State conrmissioner of weights and measures, Indianapolis, Ind.

C. R. MCFADDEN, sealer of weights and measures of Licking County, Pataskala, Ohio.

WILliam A. PAYNe, sealer of weights and measures of Monroe County, Rochester, N. Y.

B. W. RAGLAND, chief, bureau of weights and measures, Richmond, Va.

GEORGE M. RoBERTs, superintendent of weights, measures, and markets, Washington, D. C.

WILliam F. Steinel, sealer of weights and measures, Milwaukee, Wis.

V. A. Stoval, chief State inspector of weights and measures, Austin, Tex.

HAROLd A. WEBSTER, State commissioner of weights and measures, Concord, N. H.

S. H. Wilson, State oil chemist, Atlanta, Ga. 


\section{COMMITTEE ON SPECIFICATIONS AND TOLERANCES}

\section{(Stauding committee)}

F. S. HolBrooK, Bureau of Standards, Washington, D. C.

WILLIAM F. CLUETT, chief deputy inspector of weights and measures, Chicago, Ill.

CHARLES M. FULLER, city and county sealer of weights and measures, Los Angeles, Calif.

A. IV. SCHWARTz, assistant State superintendent of weights and measures, Elizabeth, N. J.

I. L. Mrlles, State commissioner of weights and measures, Indianapolis. Ind.

COMMITTEE ON UNIFORMITY IN WEIGHTS AND MEASURES REQUIREMENTS

(Standing committee)

J. H. MEEK, director State division of markets, Richmond, Va.

P. D. DukEsherer, director State bureau of foods and standards, Lansing, Mich.

D. E. Fitzgeraln, sealer of weights and measures, Racine. Wis.

Philip T. PrLox, State inspector of weights and measures, Hartford, Comm.

Albert B. SMrth, director State bureau of standard weights and measures, Harrisburg, $\mathrm{Pa}$.

C. P. Surth, sealer of weights and measures of Suffolk County, Riverhead. న. I.

V. A. Stovall, chief State inspecto: of weights and measures. Austin, Tex.

\section{ACTING COMMITTEES FOR THE TWENTY-THIRD NATIONAL CONFERENCE}

Committee on resolutions.-A. B. SMith, P. D. DUkeshrerer, J. H. Foley. S. H. Wilson, Thomas Flahfrty, S. T. Griffith, J. A. Stwerey.

Committee on nominations.-Fratcis Merenith, I. L. Minler, George Warner, W. A. Payne, B. W. Raglatd.

\section{OFFICIAL STENOGRAPHER}

Norman L. Knauss, Bureau of Standards, Washington, D. C. 


\section{IIST OF PERSONS ATTENDING THE CONEERENCE}

\section{DELEGATES-STATE, COUNTY, AND CITY OFFICIAIS}

\section{ALASAIKA}

City : Bilmingbam

R. C. SHARP, chief inspector of weights and measures, room 200. City Hall.

\section{CAIIFORNIA}

City and County :

Los Angeles.

Charles M. Fuller sealer of weights and measures, 230 Court Street, Los Angeles.

San Francisco

THOMAS FrafHFrT, sealer of weights and measures, room 6, City Hall, San Francisco.

\section{CONNECTICUT}

State_-_-_._-_._._. Prim T. PIIox, inspector of weights and measures, 100 Washington Sireet, Hartford.

City :

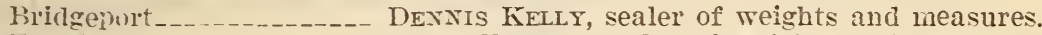

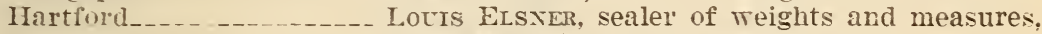
550 Miain street.

New Havell_______- Ent And J. MAroxer, sealer of weights and measures, City Hall.

County :

Fairfield_._._._. William H. Brows, sealer of weights and measures, County Courthouse, Bridgeport.

Hartford

Miro C. Griffix, sealer of weights and measures, 95 Trashington Street, Hartford.

Middlesex________. G. Erxest Hubbard. sealer of weights and measures, Middletown.

New Haren_._____. William P. TrLer. sealer of weights and meas. ures, County Courthouse, New Haven.

\section{DELAWARE}

County : Sussex

DALLAS M. Rogers. regulator of weights and measures, Georgetown.

DISTRICT OF COLUMBIA

District

IV. C. Ditrer, chief inspector of weights, measures, and markets. District Building, Washington.

GEORGE A. Hown, inspector of weights, measures, and markets, District Building, Washington.

G. STCART REEDER, inspector of weights, measures, and markets. District Building, Washington.

\section{GEORGIA}

State

S. H. WIrsox, State oil chemist, room 37, State Capitol, Atlanta.

\section{IDAFO}

State

ERAest J. Crouch, director bureau of weights and measures, room 108, Statehouse, Boise. 


\section{ILIINOIS}

State.

W. T. Fossetr, superintendent of standards, roon 214, State Capitol, Springfield.

Mrs. EtheI PASs, secretary to superintendent of standards, room 214, State Capitol, Springfield.

\section{INDIANA}

State

I. L. MILler, commissioner of weights and measures, room 201, Statehouse Annex, Indianapolis.

City: South Bend

Charles J. Burss, inspector of weights and measures, City Hall.

County: Huntington

DEForest MCLIN, sealer of weights and measures, Huntington.

\section{IENTUCKY}

City : Louisville

E. F. KNAUER, chief inspector of weights and measures, City Hall.

\section{MATNE}

City:

Portland

C. V. Frcketт, sealer of weights and measures, City Building.

Skowhegan

JoSEPH H. MURRAY, sealer of weights and measures.

Waterville_-

Wrlliam A. Jones, sealer of weights and measures.

\section{MARYLAND}

City: Baltimore

S. T. GRIFFITH, chief, division of weights and measures, City Hall.

William A. ClUBB, inspector of weights and measures, City Hall.

Charles G. Crockett, inspector of weights and measules, City Hall.

JAMES T. EVERETT, inspector of weights and measures, City Hall.

WILITAM H. LARRIMORE, inspector of weights and measures, City Hall.

GeORge H. LeithaUSER, insnector of weights and measures, City Hall.

THOMAS J. NAPFEL, inspector of weights and measures, City Hall.

Elmer S. PIERPoNt, inspector of weights and measures, City Hall.

Charles Rustebera, inspector of weights and measures, City Hall.

HeNry Slitzer, assistant inspector of weights and measures, City Hall.

Charles Zuschlag, inspector of weights and measures, City Hall.

\section{MASSACHUSETTS}

State

Francis Meredith, director of standards, room 194, Statehouse, Boston.

ADELBERT L. JONES, inspector of standards, room 194, Statehouse, Boston.

\section{City :}

Arlington

Allan E. CowIE, sealer of weights and measures, Town Hall.

Boston JAMES A. SwEENEY, sealer of weights and measures, City Hall Annex.

Springfield

WILLIAM Foster, sealer of weights and measures, room 9, Administration Building.

Worcester.

HoMER J. MELIDY, deputy sealer of weights and measures, City Hall. 


\section{MICEIGAN}

State and standards, Lansing.

City: Detroit_............. George F. Austin, Jr, assistant supervisor, bureau of weights and measures, 1300 Beaubien Street.

City aud County: Saginaw_-_- GEORGE W. MAHN, sealer of weights and measures, City Hall, Saginaw.

\section{NEW HAMPSHIRE}

City: Manchester

Arthur J. Provencher, sealer of weights and measures.

\section{NEW JERSEY}

State

J. HARRY FoLEY, superintendent of weights and measures, Trenton.

Euliots B. Holton, assistant superintendent of weights and measures, Trenton.

HARRY S. PROVOsT, assistant superintendent of weights and measures. Trenton.

JOSEPH G. RoGERS, assistant superintendent of weights and measures, Trenton.

A. W. SchWARTz, assistant superintendent of weights and measures, Elizabeth.

City :

Bayonne

WALTER J. FLYNN, superintendent of weights and measures, Municipal Building.

Elizabeth

WILLIAM J. BENDER, superintendent of weights and measures, Harmonia Building.

Englewood

James E. Fitzgerald, superintendent of weights and measules, City Hall.

Jersey City

JоHN S. BuRKe, superintendent of weights and measures, City Hall.

Kearny_-_._._._._._. JoHN D. CAsthes, superintendent of weights and measures, Town Hall.

Newark

Patrick J. CaUfield, superintendent of weights and measures, City Hall.

Trenton_.._-_._- FrANcIs J. BLACK, superintendent of weights and measures, City Hall.

County:

Bergen

A. F. BARNARD, superintendent of weights and measures, 29 Main Street, Hackensack.

Cape May

GILBERT S. Smith, superintendent of weights and measures, Avalon.

Gloucester

WilLIAM P. ABDILL, superintendent of weights and measures, Woodbury.

Hudson

THOMAS J. WALDRoN, superintendent of weights and measures, Courthouse, Jersey City.

Mercer

RALPH M. BODENWIESER, superintendent of weights and measures, Courthouse, Trenton.

Middlesex

JosEPH FERTIG, superintendent of weights and measures, 184 Livingston Arenue, New Brunswick.

Monmouth

ROBERT M. MARKS, assistant superintendent of weights and measures, Manasquan.

Morris

HENRY S. WORMAN, superintendent of weights and measures, Boonton.

Sussex

R. LEE SLATER, superintendent of weights and measures, Newton.

Union

ISAAC SEELEY, superintendent of weights and and measures, Courthouse, Elizabeth. 


\section{NEW YORZ}

State

C. P. NORGORD, assistant commissioner of agriculture and markets, Albany.

City : Rochester

J. H. Stephiensox, sealer of weights and measures.

\section{County :}

Allegany

Monroe

Rockland

Suffolk

ALLEx W. Corwin, sealer of weights and measures, 21 Osborn Street, Wellsville.

W. A. PAYNE, sealer of weights and measures, 305 Terminal Building, Rochester.

H. W. Sherman, deputy sealer of weights and measures, 305 Terminal Building, Rochester.

THomas L. SHANKEX, sealer of weights and measures, Haverstraw.

C. P. SмrтH, sealer of weights and measures, Riverhead.

\section{NORTH CAROLINA}

State

WIILTAM H. Richardson, editor, department of agriculture, Raleigh.

\section{OHIO}

State

J. C. TINкет, deputy sealer of weights and measures, Columbus.

City: Cleveland

G. A. Votaw, commissioner of markets, weights, and measures.

County : Licking

C. R. MCF $\triangle D D E x$, deputy sealer of weights and measures, Pataskala.

\section{PENNSYIVANIA}

State

Alber'T F. Sirtiry, director burean of standard weights and measures, Harrisburg.

OSCAR B. BAKER, assistant director, bureau of standard weights and measures, Harrisburg.

City :

Philadelphia

Conjers B. Graham, chief clerk, bureau of weights and measures, room 305, City Hall.

WOODWARD ABRAHAMs, district supervisor, bureau of weights and measures, room 305, City Hall.

JАCOB M. VANDERSLICE, district supervisor, bureau of weights and measures, room 305, City Hall.

Charles C. Miller, inspector, bureau of weights and measures, room 305, City Hall.

York

D. L. SтоUсн, inspector of weights and measures, 460 West Market Street.

County :

Allegheny

Thomas I. Howard, chief inspector of weights and measures, Courthouse, Pittsburgh.

Dauphin

John E. Bowers, inspector of weights and measures, 13 South Third Street, Harrisburg.

Lebigh

HARRY E. BIERT, inspector of weights and measures, Courthouse, Allentown.

City and County :

Beaver Falls and Beaver County.

Easton and Northampton County.

Chester Rimbi, inspector of weights and measures, Beaver Falls.

JoHN J. WEPPEL, inspector of weights and measures, Courthouse, Easton.

\section{RHODE ISLAND}

City : Providence.

Louis B. JoNes, superintendent of weights and measures. 


\section{TENNESSEE}

City : Chattanooga

T. F. MAHoxEI, sealer of weights and measures, City Hall.

\section{TEXAS}

State-_-_. STorall, chief inspector of weights and measures, Austin.

\section{UTAF}

City: Salt Lake City

Cits:

Charlottesriile

Danville

Richmond

I;. D. NeBEKER, superintendent of meights and neasures and oil inspection, Safety Building.

\section{VERMONT}

C. R. WHITE, commissioner of reights and measures, Montpelier.

H. N. DAIIS, deputy commissioner of weights and measures, Montpeliel.

\section{VIRGINIA}

J. H. MEEK, director dirision of markets, 1030 State Office Building, Richmond.

F. G. CovILLE, field representative, division of markets, 1030 state Oflice Building, Richmoncl.

I. E. HALL, Jr., sealer of weights and measures, City Hall.

CrEorge S. Dren, sealer of weights and measures.

i3. WT. RAGLAND, chief, bureau of weights and measures, $31 \pm$ City Hall Annex.

\section{WEST VIRGINIA}

State-

Howard S. Jamretr, commissioner of weights and measures, Charleston.

P. R. EdLER, inspector of weights and measures, Charleston.

I'. T. SCLLTVA, inspector of weights and measures, 1110 Fifth Street, Moundsville.

\section{WISCONEIN}

State

George W. WARxer, chief inspector of weights and measures, Capitol Building, Madison.

City :

inilnaukee.

Tillial F. Steivel, sealer of weights and measures, 421 Fifth Street.

West Allis.

ERTix J. Rogers, sealer of weights and measures.

\section{OTHER DELEGATES, AND GUESTS APPEARING ON THE PROGRAM}

BARrett, Herbert F., assistant sales manager, Buffalo Meter Co., 2917 Main Street, Buffalo, N. Y.

Bets, H. S., Bureau of Standards, Washington, D. C.

Bearce, H. W.. Bureau of Standards, Washington, D. C.

Blarchard, R. K., vice president Neptune Meter Co., 50 East Forty-second Street, New York, N. Y.

BUPGeSS, Dr. GEORGE K., Director Bureau of Standards, Washington, D. C.

Cuntrs, W. H., research engineer, National Recording Pump Co., Dayton, Ohio. DARTT, CARL E., president Columbia Scale Co., 634-614 Whitlock Arenue, New York, N. Y.

GotLD, R. E., Bureau of Standards, Washington, D. C. 
Griffith, C. P., engineer, S. F. Bowser \& Co. (Inc.), Fort Wayne, Ind.

HADLICK, PAUL 12., secretary, division of marketing, American Petroleum Iustitute, 250 Park Avenue, New York, N. Y.

HARRIsorv, M. J. J., chairman committee on specifications, National scale Men's Association, Union Station, Chicago, Ill.

Hitzeman, A. P., chief engineer The Wayne Co., Fort Wayne, Ind.

HoLbrook, F. S., Bureau of Standards, Washington, D. C.

Hubrard, H. D., Bureau of Standards, Washington, D. C.

Jubson, L. V., Bureau of Standards, Washington, D. C.

KLeIn, Hon. Juliuis, Assistant Secretary of Commerce. Washington, D. (:.

LoHmann, Henry, National Association of Retail Grocers, $8 f 14$ Ninety-first Avenue, Woodhaven, N. Y.

Maclean, Atuen D., chief engineer Pittsburg Equitable Meter Co.. 400 North Lexington Avenue, Pittsburgh, Pa.

Miller, D. R., Bureau of Standards, Washington, D. C.

Palmer, Arthur W., chief, division of cotton marketing, Bureau of Agricultural Economics, United States Department of Agriculture, Washington, D. C.

Parry, William, Bureau of Standards, Washington, D. C.

Peffer, E. L., Bureau of Standards, Washington, D. C.

Perkins, Hon. Randolpr, chairman Committee on Coinage, Weights, and Measures, House of Representatives, Washington, D. C.

PIENkowsky. A. T., Bureau of Standards. Washington, D. C.

RichaRd, C. L., Bureau of Standards Master Scale Depot, Clearing Station, Chicago, III.

Roeser, H. M., Bureau of Standards Master Scale Depot, Clearing Station, Chicago, Ill.

SMith, RALPH W., Bureau of Standards, Washington, D. C.

Spilman, H. A., senior marketing specialist, Bureau of Agricultural Economics. United States Department of Agriculture, Washington, D. C.

SoUder, WILMER, Bureau of Standards, Washington, D. C.

WARD, RoBErT J., gasoline meter division, Worthington Pump \& Machinery Corporation, Harrison, N. J.

\section{GUESTS REPRESENTING MANUFACTURERS}

Becker, Christian (Inc.) : C. A. BEckEs, 147 Eight Street, Jersey City, N. J.

Black \& Decker Manufacturing Co. : E. E. PowEL, traffic engineer, Towson. Md.

Bowser, S. F., \& Co. (Inc.) :

Dan. G. Milligan, vice president, Fort Wayne, Ind.

C. P. Griffith, engineer, Fort Wayne, Ind.

Buffalo Meter Co.: HerberT F. BARretr, assistant sales manager, 2917 Main Street, Buffalo, N. Y.

Chatillon, John, \& Sons :

P. r. BortmiL, sales manager, 89 Cliff Street, New York, N. Y.

W. T. HA YDock, 89 Cliff Street, New York, N. Y.

J. George HugE,, 89 Cliff Street, New York, N. Y.

Columbia Scale Co. (Inc.) : CARL E. DARTt, president, 6.84-64t Whitlock Arenue, New York, N. Y.

Continental Scale Works: M. J. WEBER, vice president, 5701 South Claremont Avenue, Chicago, Ill.

Davis Welding \& Manufacturing Co.: E. W. SchutTe, secretary-treasurer, Cincinnati, Ohio.

Dayton Pump \& Manufacturing Co.: C. C. Helder, service managér, 500 Webster Street, Dayton, Ohio.

Dover Stamping \& Manufacturing Co.: Lours S. Cledves, rice president, 385 Putnam Avenue, Cambridge, Mass.

Erie Meter Systems (Inc.): G. W. McDougall, sales manager, Erie, Pa.

Exact Weight Scale Co.: Jоно G. Snss, vice president, 944 West Fifth Arenue, Columbus, Ohio.

Fairbanks, Morse \& Co. :

H. L. Hilleary, district manager, railroad division, 160 Varick Street, New York, N. Y.

E. P. Vroone, sales engineer, 160 Varick Street, New York, N. Y.

C. A. Hennit, scale department manager, 115 East Lombard Street, Bat. timore, Ma. 
Gilbert \& Barker Manufacturing Co.:

J. A. Logan, chief engineer, Springfield, Mass.

G. C. RoBerts, general sales manager, Springfield, Mass.

H. W. Lipurax, salesman, Springfield, Mass.

Gray Co., The: Harry D. Sirth, 2401 Chestnut Street, Philadelphia, Pa.

Gurley, W. \& L. E. : W. L. EgY, engineer, 514 Fulton Street, Troy, N. Y.

Hollingshead, R. M., Co. :

R. M. BAgley, vice president, Camden, N. J.

LEsLIE A. THompson, railroad sales manager, Camclen, N. J.

Howe Scale Co.: C. A. LrNDSAY, branch manager, 415 Arch Street, Philadelphia, Pa.

International Business Machines Corporation:

S. M. Templeton, vice president, Dayton Scale Co. division, Daytou, Ohio.

U. RAIFF, chain-store manager, Dayton Scale Co. division, 270 Broadway, New York, N. Y.

HARRY S. EvaNs, Washington manager, 816 Fourteenth Street, Washington, D. C.

W. G. Egerton, Washington manager, Dayton Scale Co. division, 816 Foulteenth Street, Washington, D. C.

Jacobs Bros. Co. (Inc.) :

H. M. JAcoBs, secretary-treasurer, 32 walton Street, Brooklyn, N. X.

CHARLeS RICHARD BRody, assistant general manager, 32 Walton Street. Brooklyn, N. Y.

J. E. Woodland, sales manager, detectogram dirision, 32 Walton Street. Brooklyn, N. Y.

Kellogg Manufacturing Co.: J. K. GiLchrist, sales-promotion manager, $97 \mathrm{Hum-}$ boldt Street, Rochester, N. Y.

L N S Corporation:

A. A. Hodgkins, 71 Murray Street, New York, N. Y.

BJorivulf JoHnsen, mechanical engineer, 71 Murray Street, New York, N. Y.

Logan Allington Co.: E. W. Allington, secretary, 135 East Forty-second Street, New York, N. Y.

Mathewson Machine Works: W. B. Mathewsox, Quincy, Mass.

Measuregraph Co.: E. A. Powetr, service manager, 3905 Belle Arenue, Baltimore, Md.

Moore \& Kling (Inc.) : Eumer M. KLING, Boston, Mass.

National Pipe Products Corporation:

W. S. TownSEND, chairman board of directors, Rochester, Pa.

LyoN McCandless, Rochester, Pa.

National Recording Pump Co.: W. H. Cortis, research engineer, Dayton, Ohio. Neptune Meter Co.:

R. K. BLANCHARD, rice president, 50 East Forty-second Street, New York, N. $\mathrm{Y}$.

F. R. Gammor, sales engineer, 50 East Forty-second Street, New York, N. Y.

Ohmer Fare Register Co.:

ROBERT B. ALEXANDER, branch manager, 1632 Fourteenth Street, Washington, D. C.

B. C. PaLmer, sales engineer, New York, N. Y.

Oil Station Engineering Co.: HARRY D. SMITH, president, 2401 Chestnut Street, Philadelphia, $\mathrm{Pa}$.

Peerless Weighing Machine Co.: E. M. ScHIEMER, district manager, 245 Fifth Avenue, New York, N. Y.

Pittsburgh Equitable Meter Co. :

Aluex D. Maclean, chief engineer, 400 North Lexington Avenue, Pittsburgh, $\mathrm{Pa}$.

H. I. BEARDSLEY, manager, oil and gasoline meter division, 400 North Lexington Avenue, Pittsburgh, $\mathrm{Pa}$.

Horace Chrisman, engineer, 400 North Lexington Arenue. Pittsburgh, Pa. Roy Manufacturing Co.: Frank J. OLdFIELd, rice president, 230 Tater Street, Quincy, Mass.

St. Louis Pump \& Equipment Co.: HARry D. Smrth, 2401 Chestnut Street, Philadelphia, $\mathrm{Pa}$.

Sanitary Scale Co.: ANSoN G. SENER, rice president, 11 West Forty-second Street, New York, N. Y.

Seederer-Kohlbusch (Inc.) : Edwin C. Smitr, sales manager, 149 New York Avenue, Jersey City, N. J. 
Seraphin Manufacturing Co.: Theo. A. Seraphin, president, 1314 North Seventh Street, Philadelphia, Pa.

Service Station Equipment Co.:

C. W. WeAVER, manager, gasoline pump division, room 302, 32 Broadway, New York, N. Y.

F. O. Sallee, division manager, 1002 American Building, Baltimore, Md.

Sexton Can Co.: Frank A. Joengor, salesman, Buston, Mass.

Standard Computing Scale Co.: W. Ton WHITE, factory representative, 2461

East Grand Boulevard, Detroit, Mich.

Tokheim Oil Tank \& Pump Co.:

M. B. Muxen, president, Fort Wayne, Ind.

CFEster C. OBERLY, sales manager, fort Wayne, Ind.

R. E. Langston, engineer, Fort Wayne, Ind.

W. M. Frazine, district manager, Baltimore, Md.

Toledo Scale Co.: C. C. NEALE, special representative, Toledo, Ohio.

Torsion Balance Co.: A. T. Mulnoy, 92 Reade Street, New York, N. Y.

Triner Scale \& Manufacturing Co.: J. M. TRINER, president and treasurer, 2714

West Twenty-first Street, Chicago, Ill.

Universal Lubricating Devices (Inc.):

Richard Betz, service manager, 597 Butler Street, Pittsburgh, Pa.

E. A. Luster, factory representative, 597 Butler Street, Pittsburgh, P:.

Universal Pump \& Tank Corporation:

F. Chandton, president, 3860 East Ninety-first Street, Cleveland, Ohio.

C. Spazth, 3860 East Ninety-first Street, Cleveland, Ohio.

Veeder Root (Inc.) : I. W. Stevens, factory superintendent, Hartford, Conu.

Wayne Co., The:

A. D. CARriger, vice president, 1780 Broadway, New York, N. I.

A. P. Hitzeman, chief engineer, Fort Wayne, Ind.

R. A. Dempser, district manager, 6:24 South Michigan Avenue, Chicugo, Ill.

C. B. Hanwext, district manager, Philadelphia, Pa.

M. C. Brown, 1414 Girard Street, NE., Washington, D. C.

Worthington Pump \& Machinery Corporation: RoBERT J. WARD, gasoline meter division, Harrison, N. J.

\section{GUESTS REPRESENTING TRADE ASSOCIATIONS}

American Petroleum Institute:

PAUL E. HADLICK, secretary, division of marketing, 250 Park Arenue, New York, N. Y.

David V. Stroop, engineer, 250 Park Avenue, New York, N. Y.

National Association of Retail Grocers: HeNry Lohmanx, 8614 Ninety-ïst Avenue, Woodharen, N. Y.

\section{GUESTS REPRESENTING RAIIROADS AND WEIGHING DEPARTMENTS}

Dean, T. O., superintendent of scales. Texas \& Pacific Railway, Dallas, Tex.

DugaN, J. W., chief, weighing bureau, St. Louis-San Francisco Railroad, Springfield, Mo.

ECKER, GEonge M., scale inspector, Central Railroad of New Jersey, Mauch Chunk, Pa.

EPRIGHT, A. W., superintendent scales and weighing, Pennsylvania Railroad, Altoona, Pa.

Gor, R. B., supervisor weighing and inspection, Illinois Central Railroad, Chicago, Ill.

HARrison, M. J. J., general scale inspector, Pennsylvania Railroad, Chicago, Ill.

Hicks, B. L., supervisor of weights, Western Weighing and Inspection Bureau, 1800 Transportation Building, Chicago, Ill.

Hosford, C. C., general scale inspector, Pennsylvania Railroad, Pittsburgh, Pa.

Klotz, Wilciam G., superintendent of scales, Missouri Pacific Lines of Tesas, 204 Union Station, Houston, Tex.

LADD, M. H., chief weigher, Milwaukee Chamber of Commerce, Milwaukee, Wis.

LAWRENCE, E. KENT, general scale inspector, Baltimore \& Ohio Railroad, Baltimore, $\mathrm{Md}$.

ManN, C. H., superintendent of scales, Southern Railway System, Washington, D. C. 
MoKar, W. M., scale inspector, Missouri Pacific Railroad, St. Louis, Mo.

PeтTis, C., general scale inspector, New York Central Railroad, Rochester, N. $\mathbf{Y}$. Pherigo, J. L., chief scale inspector, Southern Railway, McPherson Square, Washington, D. C.

SchlinkERT, F. H., superintendent of scales, Missouri Pacific Railroad, 1200 Missouri Pacific Building, St. Louis, Mo.

Welsh, RoBerT C., general scale inspector, Pennsylvania Railroad, Harris. burg, $\mathrm{Pa}$.

\section{GUESTS REPRESENTING GOVERNIMENT DEPARTMENTS}

BrIGGS, C. A., livestock weight supervisor, Bureau of Animal Industry, United States Department of Agriculture, Washington, D. C.

De Mayola, ERnest A., Bureau of Public Roads, United States Department of Agriculture, Washington, D. C.

Gerdes, Francis L., junior agricultural economist, United States Department of Agriculture, 300 Linworth Place SW., Washington, D. C.

SpILman, H. A., senior marketing specialist, Bureau of Agricultural Economics, United States Department of Agriculture, Washington, D. C.

Palmer, ARTHUR W., chief, division of cotton marketing, Bureau of Agricultural Economics, United States Department of Agriculture, Washington, D. C.

\section{OTHER GUESTS}

Baker, B. E., Standard Oil Co. of New York, 230 Park Avenue, New York, N. Y. French, G., Sinclair Refining Co., 45 Nassau Street, New York, N. Y.

JacoBs, Edith G., secretary Scale Journal Publishing Co., 309 South LaSalle Street, Chicago, Ill.

KERNS, F. C., superintendent lubricating sales, The Texas Co., 135 East Fortysecond Street, New York, N. Y.

LYoNs, JoHN F., supervisor weights and measures department, American Stores Co., 419 North Nineteenth Street, Philadelphia, Pa.

MacDermotT, F. N., sales department, Atlantic Refining Co., 260 South Broad Street, Philadelphia, Pa.

Malone, H. B., director of purchases Sinclair Refining Co., 45 Nassau Street, New York, N. Y.

Marchant, Harry, scale inspector, Bethlehem Steel Co., Sparrows Point, Md. Morris, Homer I., Sun Oil Co., 1608 Walnut Street, Philadelphia, Pa.

Round, GEORGE A., assistant chief, engineering division, Vacuum Oil Co., 61 Broadway, New York, N. Y.

Russeld, Samued, 109 First Street NE., Washington, D. C.

Saybolt, J. W., sales manager Standard Oil Co. of New Jersey, 26 Broadway, New York, N. Y.

TAliaferRo, Lindsay C., service-station department, Standard Oil Co. of New Jersey, Standard Oil Building, Baltimore, Md. 


\section{CONTENTS}

\section{First Session (Morning of Tuesday, June 3, 1930)}

Opening address by the president, Dr. George K Abstracts of State reports:

Alabama, R. C. Sharp.

California, J. S. Casey

Connecticut, Philip T. Pilon

Delaware

District of Columbia

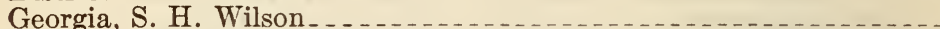

Idaho, Ernest J. Crouch

Illinois, W. T. Fossett.

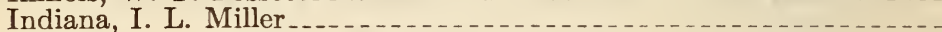

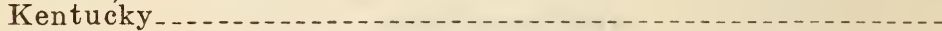

Maine

Maryland, S. T. Griffith

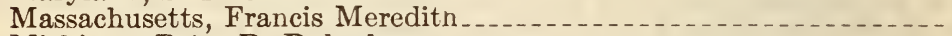

Michigan, Peter D. Dukesherer

New Hampshire $\ldots \ldots \ldots$

New Jersey, J. Harry Foley . . . . . . . . . . . . . . . . . . . . .

New York, C. P. Norgord

North Carolina, William H. Richardson ......................

Ohio, J. C. Tinkey

Pennsylvania, Albert B. Smith

Rhode Island, Louis B. Jones . . .

Tennessee, T. F. Mahoney . . . . . . . . . . .

Texas, V. A. Stovall

Utah, B. D. Nebeker.

Announcement and motion

Second Session (Afternoon of Tuesday, June 3, 1930)

Abstracts of State reports-Continued:

Vermont, H. N. Davis.

Virginia, J. H. Meek

West Virginia, Howard $\mathrm{S}$ Jarrett

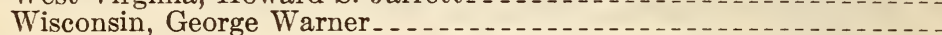

Abstracts of reports of representatives of State associations of weights and measures officials:

Indiana Association of Inspectors of Weights and Measures, I. L. Miller. .........

Massachusetts Association of Sealers of Weights and Measures, Homer J. Melidy

Michigan State, County, and City Sealers Association, George W. Mahn .-.

New Jersey Weights and Measures Association, Joseph G. Rogers.

New York State Association of Sealers of Weights and Measures, J. H. Stephenson

Ohio Sealers' Association, J. C. Tinkey Notes on grease-measuring devices, by Ralph W. Smith, Bureau of

The sale of cotton by net weight and the standardization of the bale, by Arthur W. Palmer, chief, division of cotton marketing, Bureau of Agricultural Economics, United States Department of Agriculture...-. Discussion of above paper 
Cooperation with weights and measures officials, by Paul E. Hadlick, representing the American Petroleum Institute_....

Discussion of above paper

Report of committee on specifications and tolerances on modification of specifications for grease-measuring devices, presented by F. S. Holbrook, chairman

Page

Third Session (Morning of Wednesday, June 4, 1930)

Report of committee on specifications and tolerances on specifications and tolerances for odometers, presented by F. S. Holbrook, chairman.-

Discussion of above report
Address by the chairman of the Committee on Coinage, Weights, and Measures, House of Representatives, Hon. Randolph Perkins.-. Some observations on weights and measures administration, by C. P. Norgord, assistant commissioner of agriculture and markets, State of New York

The standard container act of 1928, by $\mathrm{H}$. A. Spilman, senior marketing specialist, Bureau of Agricultural Economics, United States Department of Agriculture . . . . . .

Address by the Assistant Secretary of Commerce, Hon. Julius Klein...-

Fixing of effective date of specifications and tolerances for grease-measuring devices

Discussion of paper on standard container act of 1928

Appointment of committees

The sale of chemically treated coal, by I. L. Miller, commissioner of weights and measures, State of Indiana........

The retail grocer, by Henry Lohmann, representing the National Associa-

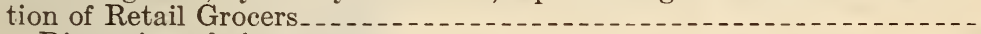

Discussion of above paper

Fourth Session (Afternoon of Wednesday, June 4, 1930)

Tour of the laboratories of the Bureau of Standards

\section{Fifth Session (INorning of Thursday, June 5, 1930)}

The inspection of weights and measures in pharmacies, by George F. Austin, jr., assistant supervisor, bureau of weights and measures, De-

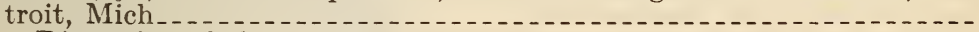

Discussion of above paper

Report of committee on specifications and tolerances on specifications and tolerances for automatic-indicating scales, presented by F. S. Holbrook, chairman

The suppression of fraudulent practices, by J. M. Vanderslice, district supervisor, bureau of weights and measures, city and county of Philadelphia, $\mathrm{Pa}$

Discussion of above paper

The annual report of the official:

Discussion of the scope and preparation of the report, by H. S. Jarrett, commissioner of weights and measures, State of West Virginia...-

Graphical presentation of data, by Henry D. Hubbard, Bureau of Standards

Demonstration of gasoline meters by manufacturers

\section{Sizth Session (Afternoon of Thursday, June 5, 1930)}

Demonstration of gasoline meters by manufacturers (continued) ........ Discussion of above number

Air releases on power-operated gasoline-dispensing units, by A. W. State of New Jersey

Testing vehicle-tank meters, by Massachusetts inspectors of standards.-

Discussion of above paper
Calibrating vehicle-tank compartments by liquid meters, by H. N. Davis, deputy commissioner of weights and measures, State of Vermont......

Discussion of above paper. 
Calibrating vehicle tanks by large-capacity measures, by S. T. Griffith, chief, division of weights and measures, city of Baltimore, Md......

Citation by weights and measures officials of important court decisions in their jurisdictions

Announcements.

Seventh Session (Morning of Friday, June 6, 1930)

Report of committee on specifications and tolerances on modification of various codes, presented by F. S. Holbrook, chairman

The use and abuse of person-weighing scales, by Carl E. Dartt, president Columbia Scale Co

Discussion of above paper..........

Log rules, by A. W. Corwin, sealer of weights and measures, county of Allegany, N. Y

Motion in relation to special expenditure

Side-beam and hidden-weight scales, by J. C. Tinkey, deputy sealer of weights and measures, State of Ohio

Standardization activities of the National Scale Men's Association, by M. J. J. Harrison, chairman, committee on specifications, National Scale Men's Association

Scale Men's Association

General consideration of subjects of interest and questions brought up for discussion by officials . .

Resignation of the treasurer, George F. Austin

Report of committee on nominations, presented by Francis Meredith, chairman, and election of officers

Report of committee on resolutions, presented by Albert B. Smith, chairman:

Address of the Assistant Secretary of Commerce, Hon. Julius Klein - -

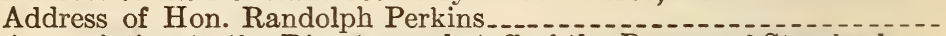

Appreciation to the Director and staff of the Bureau of Standards..-

Retirement of George F. Austin

Chemically treated coal

Lubricating-oil bottles not complying with specifications.........

Molds and machine-filled cartons for ice cream ...................

Appreciation to manufacturers demonstrating gasoline meters .......

Commendation to far-western States for representation at conference.

George Washington Bicentennial

Appreciation to headquarters hotel management. . . . . . . . .

Appreciation to the press

Discussion of report of committee on resolutions.....................

Resolution in relation to standardization activities of the National Scale

Men's Association .

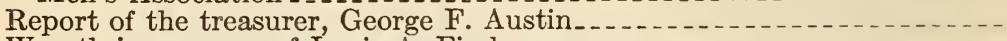

Wreath in memory of Louis A. Fischer.

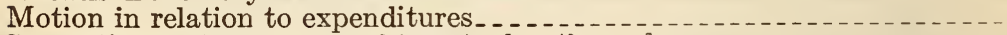

Suggestion as to program of twenty-fourth conference:

Desirability of specifications and tolerances for person-weighing scales

\section{APPENDIX}

Specifications and tolerances for automatic-indicating scales, adopted by the Twenty-third National Conference on Weights and Measures, June 5, 1930 


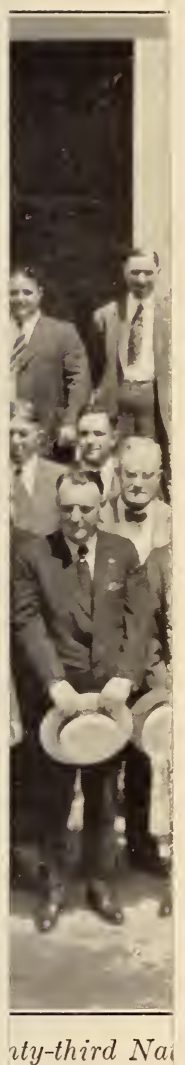




\title{
REPORT OF THE TWENTY-THIRD NATIONAL CONFERENCE ON WEIGHTS AND MEASURES
}

\author{
HELD AT THE BUREAU OF STANDARDS, WASHINGTON, D. C., \\ JUNE 3-6, 1930
}

\section{FIRST SESSION (MORNING OF TUESDAY, JUNE 3, 1930)}

The conference was called to order at 10.55 o'clock a. m. by Dr. George K. Burgess, president of the conference.

OPENING ADDRESS BY THE PRESIDENT, DR. GEORGE K. BURGESS

Members of the conference and guests, it is again my duty and privilege to welcome you to this Twenty-third National Conference on Weights and Measures and to express my pleasure at seeing so many old friends among you. I wish also especially to greet those of you who are here for the first time, and to assure you that your active participation in the work of the conference will be most helpful,

It is with particularly keen regret that I note the absence of one of our most valued and helpful members, William F. Cluett, of Chicago, who on account of illness is missing for the first time in many years. I am sure you all join me in wishing him a speedy and complete recovery.

It has been customary in past years in my address to you to devote some attention to the subject of Federal legislation relating to weights and measures. The Congress has given somewhat less attention to matters directly related to weights and measures than has sometimes been the case.

The only new matters relating to weights and measures introduced since our last meeting are two resolutions pertaining to the metric system and a bill to provide for regulating traffic in certain clinical thermometers.

House Joint Resolution 124 provides that the Department of Commerce be authorized to establish commodity quantity units for general use in merchandising after 1935, standardizing the customary units to metric units; and House Resolution No. 125 would authorize and direct the Secretary of Commerce to conduct an investigation to determine the advantages and disadvantages of the general use in the United States of the metric system of weights and measures.

H. R. 9586, relating to clinical thermometers, prohibits the shipment in interstate or foreign commerce of any clinical thermometer which has not been tested or marked in accordance with the provisions of the bill. It further provides for the testing of thermometers under rules and regulations to be made by the Secretary of Com$24342^{\circ}-31-2$ 


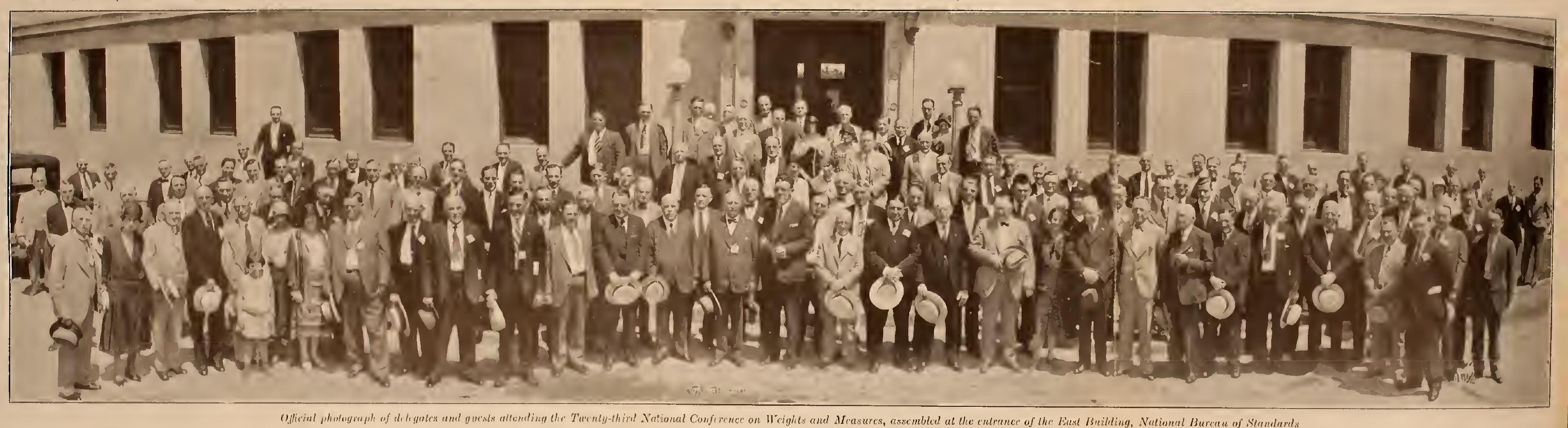

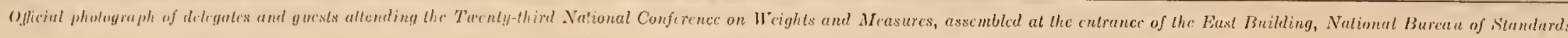


merce, such rules and regulations to include specifications and rensonable tolerances with which clinical thermometers shall conform.

The majority of the bills relating to weights and measures before Congress at the present time were introduced during the first session and reported upon at our last meeting. None of the bills has been enacted into law as yet. In relation to these I will confine my remarks to a few upon which further action has been taken by Congress, as follows:

H. R. 3, a bill to amend the national food and drugs act so as to prevent the slack filling of packages and deception by means of the form or shape of the container, passed the House on March 17, 1930.

S. 108, a bill to suppress unfair and fraudulent practices in the marketing and handling of perishable agricultural products by commission merchants in interstate and foreign commerce, passed the Senate June 3, 1929, and the House, with amendment, on May 14. 1930 , and is now in conference. This bill has a good chance of passage.

H. R. 730, a bill to amend the national food and drugs act so as to require certain canned food to be of a standard quality, condition, and fill, in accordance with standards to be promulgated by the Secretary of Agriculture, passed the House on May 7, 1930. S. 1133, identical with H. R. 730, was reported out of the Senate Committee on Agriculture and Forestry with recommendation that it pass.

I have copies of most of these bills, which are at your service for examination at any time that you may so choose.

You will doubtless be interested in hearing something of our honorary president, Dr. S. W. Stratton, whom you remember was for so many years Director of the Bureau of Standards and president of this conference, and who has since been president of the Massachusetts Institute of Technology. Doctor Stratton has recently been made chairman of the executive committee of the corporation of the institute, being relieved of the duties of president, which have been assumed by Dr. Carl Compton, of Princeton University. Doctor Stratton in his new position maintains, as chairman of the board, the authoritative position from the point of view of the policy and finances of the institute. Doctor Compton is charged, more particularly, with the educational work of the institute. I see Doctor Stratton quite frequently, and I hardly ever meet him but he expresses his very great interest in the work of these conferences on weights and measures, and I am sure if it were possible he would be here and would enjoy welcoming you also.

Knowing your interest in the work of the Bureau of Standards, I shall describe in some detail certain phases of our work during the past year which have a direct bearing upon weights and measures.

You are already familiar with our work on railroad track scales and mine scales. That work has been continued through the year, and about the usual number of scales of these general classes have been tested, through the helpful cooperation of the railroads and weights and measures officials. I may say, in passing, that the funds for those two types of work have been consolidated into a single fund, which will make administration more easy and the carrying out of the work more satisfactory. I am also glad to report, in this connection, that through special appropriation Congress has provided the sum of 
$\$ 40,000$ for the replacement of our oldest track-scale testing equipment, No. 1, which through many year's of service has become unfit for further use. We expect this car to be constructed within the next few months, and it will be put in operation as soon as possible.

The bureau has continued to cooperate with engineering societies, the American Standards Association, the American Petroleum Institute, the Federal Specifications Board, and other organizations engaged in the standardization of equipment and methods of test. The first-mentioned organization, by the way, has been reorganized within the last year. A board of directors has been set up in which the Director of the Bureau of Standards is the Government member, and the work is carried out by what is called the council of the association. As to the Federal Specifications Board, with which you are most familiar as the body which sets up and promulgates the buying and purchasing specifications for the departments, that board has been very active and is getting out specifications year after year which are used more and more by State, municipal, and other institutional buyers.

New equipment has been put into use in the optics division and in the weights and measures division of the bureau, which has materially increased the accuracy attainable in the graduation and calibration of precise standards of length. In the optics division line standards up to 4 inches in length have been graduated by means of light waves, and these have been tested on the new longitudinal comparator to an accuracy of two-millionths of an inch. A similar ruling machine, capable of ruling line standards up to 1 yard or 1 meter in length by means of light waves is nearing completion. Preliminary tests indicate a corresponding accuracy in this machine.

The new equipment in the weights and measures division includes a high-precision longitudinal comparator, a circular dividing engine, and a circle-testing machine. Although this equipment was purchased a few years ago, it is only within the past year that it has been sufficiently used to demonstrate fully its precision, accuracy, and convenience of use.

The comparator has found extensive use in the calibration of line standards ruled in the optics division, already referred to, and in the intercomparison of various high-precision line standards belonging to the bureau, and several belonging to the Canadian Government and to various universities. The consistency and precision of the results obtained are such as to indicate that our precise standards of length are on a much higher plane as to accuracy than ever before.

Good progress has also been made in the graduation and calibration of precision circles such as are used on transits and theodolites for the accurate measurement of angles. Experience so far gained. indicates that 9-inch theodolite circles graduated by the bureau are not in error by more than 2 seconds of arc, and $61 / 2$-inch circles are not in error by more than 3 seconds of arc. Calibrations of these circles by three different observers are consistent to within 1 second.

A new device developed in the volumetric section permits the testing of dilution pipettes in a much shorter time than was possible by the methods formerly in use, and at no sacrifice of accuracy. The new method makes use of a micrometer head and a cylindrical plunger of known dimensions to determine by direct measurement 
the ratio of volumes. This device has greatly speeded up our work in testing dilution pipettes which are used so extensively in medical diagnosis.

The testing equipment that I have mentioned will be on exhibition in the bureau, and I hope you will feel free either Wednesday afternoon at the time set aside for that purpose, or whenever it is convenient to you, to see any of those pieces of equipment in which you may be interested.

Returning for a moment to length standards, you may remember that at the last conference I gave a summary of the international work in regard to these standards and particularly to the work of the international committee on weights and measures of the International Bureau. There was one thing that it was hoped would be passed but which had not as yet been passed, namely, the designating of the temperature at which shop standards of length-gages and other appliances used in the shop-should have their correct nominal length. The temperature upon which practically everyone was agreed for that purpose, was $20^{\circ} \mathrm{C}$. or $68^{\circ} \mathrm{F}$. I may now say that all the countries concerned are in agreement, with the exception of Great Britain who has not yet disagreed. My latest information from Great Britain is that the industries of Great Britain, which are on a $62^{\circ} \mathrm{F}$. basis, have not yet come to accept the $68^{\circ} \mathrm{F}$. However, there are prospects that Great Britain will come in, and if she does that will make a uniform practice for shop standards.

One problem in the field of precise length measurement is receiving attention in practically all of the national research laboratories; that is, the precise measurement of length in terms of light waves. New applications of the results of research in this field seem certain to lead to still further increase in the precision and accuracy of industrial and engineering measurements of length.

A notable example is the development by two Japanese scientists of a modification of the Fabry-Perot interferometer apparatus by means of which the length of a 24-meter geodetic tape is measured directly in terms of light waves, with the same facility that short end standards are ordinarily compared. They have shown that the method is applicable to lengths up to several hundred meters.

A report of particular interest to weights and measures officials in this country and in Great Britain has recently been issued by the Board of Trade, London. This is a report of the intercomparisons carried out in 1922 to 1927 between the Imperial Standards of Great Britain and the several Parliamentary copies of these standards.

The intercomparisons reported upon are the most extensive and thorough that have been made since the adoption of the present standards. The report also includes a comparison of the metric standards of Great Britain with those of the International Bureau of Weights and Measures, and a new determination of the relation between the imperial yard and the international meter. The report is 68 pages in length; and I can, therefore, give only a brief reference to it. The general conclusion as summarized by Mr. Sears, deputy warden of the standards, is as follows:

Generat conclusions.-Although the results of the 1922-23 comparisons hare established the ralues of both the yard and the pound on a firmer basis than for some decades past, it has become rery apparent that neither series of 
standards is of a quality corresponding to that of more modern primary standards, or to the possibilities and requirements of present dav scientific and industrial derelopment. The defects remarked in the two immured standards are, to a less degree, present in all the series, and it would appear desirable that early consideration should be given to the problem of determining the best procedure to be adopted for their ultimate replacement by standards of greater accuracy and refinement.

As far as the standard of length is concerned, the International Committee for Weights and Measures have already expressed the hope that it may erentually be possible to supersede the material prototype metre by a definition in terms of the wave length of light. Investigations are already in progress in the various national laboratories with a view to formulating the proper conditions for such a definition. It would probably be best to defer any attempt to replace the existing imperial standard sard until these investigations are completed.

With regard to the standard of mass, no better material appears to be arailable than the platinum iridium alloy of which the kilogramme standards are made. If the indications of the present report are confirmed by the results of the next decennial comparisons, which fall due to be made in 1932 , it will probably be found best to proceed forthwith to reconstruct the pound standards in this alloy, prepared by the best modern processes.

I would now like to refer to some of the items on our program for this conference:

You remember last year we had the pleasure of listening to Secretary Lamont, who addressed you. This year we will hear from Doctor Klein, who is the Assistant Secretary of Commerce, and was previously for several years the Director of the Bureau of Foreign and Domestic Commerce. Having occupied those positions, Doctor Klein is closer, perhaps, to our industrial picture both at home and abroad, than any man in the United States. I am sure you will find his address of very great interest.

This year we will also be favored by an address by the Hon. Randolph Perkins, chairman of the Committee on Coinage, Weights, and Measures of the House of Representatives. The committee of which he is chairman has the duty of considering all bills which concern this conference, as they come up in Congress.

On our program we have a considerable number of other items of very great interest. Perhaps the one subject which is going to be of the greatest prominence and interest is that dealing with oil, gasoline, and greases. On Thursday we have a symposium of papers relating to those subjects, and this afternoon we shall have a paper by Paul Hadlick, representing the American Petroleum Institute, and the report of the committee on specifications and tolerances on specifications for grease-measuring devices. Your committee on specifications and tolerances has been going over the field very carefully and has had sitting in with it from time to time representatives of the industries concerned.

We also have a paper on that very important commodity, cotton, the question being one of merchandising. The paper is entitled "The Sale of Cotton by Net Weight, and the Standardization of the Bale," which is of very great importance in our commerce. This paper will be given by Arthur W. Palmer, chief of the division of cotton marketing, Bureau of Agricultural Economics, United States Department of Agriculture.

There are a number of other speakers whom I will not take the time to mention, but I am sure they will be heard with very great interest by the members of the conference. 
Turning to publications of the bureau recently issued which may be of especial interest to members of the conference, we have, of course, first, the Report of the Twenty-Second National Conference on Weights and Measures, Miscellaneous Publications, Bureau of Standards, No. 101, which has been issued for some time, and of which, I hope, all of you have already received copies.

Then we have Miscellaneous Publications No. 104, Testing Equipment for Large-Capacity Scales for the Use of Weights and Measures Officials, which we think will be useful to you in your work and in improving the facilities of your departments.

I want particularly to refer to this modest document which is called Weights and Measures References, Miscellaneous Publications No. 103. I think all of you-at least all of you who are in regular attendance-have received copies of this publication. It includes, among other things, an index of all the proceedings of these conferences on weights and measures, and I think one can not but be impressed in looking over the subject matter of this index by the very great breadth and depth and scope of the work of these conferences on weights and measures.

In this connection, I am convinced that these annual meetings of the weights and measures officials are of the very greatest importance. You discuss model laws and specifications and tolerances; you hear papers on many subjects-some are on new developments, some show the way toward the future and point out what should be done, some are controversial, some historical-all this is very useful and helpful. I feel that these conferences, starting in 1905 and continuing to date, are to be highly congratulated on the work that has been done. But that is not all; the work you have done has borne fruit elsewhere. We had, for example, in the city last week a conference of delegates from the various States interested in traffic problems. That was a voluntary conference, the same as this, made up of delegates in part appointed by the governors of the various States, in part representatives of cities, and individuals. They have a very great problem, and their method of attacking it is somewhat similar to yours. Also we have at the bureau this week the conference of the utility engineers. Their method of procedure is also quite similar. So in a way this conference has not only been responsible for what it has done itself, but it has been a good example to other lines of activity requiring voluntary cooperation on the part of representatives from the various States.

Turning again to publications, the Standards Yearbook is being issued as heretofore, annually, and the 1930 book is out. I am sorry to say it is not available for free distribution. We also have the annual report of the bureau, which is available for any of you who wish it. The work of the railroad track scale testing service of the Bureau of Standards during the fiscal year July 1, 1928, to June 30, 1929, is summarized in Letter Circular No. 276. There have been issued several publications relating to gages and screw threads. Then there is a chart for use in determining angles. Screw-thread tables are being gotten out in more convenient form for public use. We have a publication also on domestic and industrial fuel oils; also weights per United States gallon and cubic foot for sugar solutions. We have been doing some work on the question of light standards, 
and we have a report on the first spectrum of krypton. These are available for your information, and copies, except of the yearbook, can be had. Lastly, I mention the publication, Commercial Standards Monthly, which is evidently meeting a long-felt want; the subscription list of this is now, I believe, approaching 4,000.

Your chairman had the opportunity to go to Japan last fall as the delegate of the United States Government to the World Engineering: Conference. I am sorry to say that I did not have the opportunity of seeing in detail, as I had wished, the weights and measures administration of Japan. I did, however, get in contact and noted certain things of interest, and I did visit a great many laboratories. That visit was most extraordinarly interesting. The Japanese people are most remarkable, most vigorous from the point of view of development. I was greatly astounded at the enormous development they have made on standardization, on the one hand, and on research on the other; particularly in research. I did have an opportunity of seeing how they carry out their work in the inspection of electrical apparatus which is not strictly weights and measures in the purview of this conference, but nevertheless closely allied to it. The railroads of Japan belong to the Government. Means of communication also belong to the Government-that is, the radio, telegraph, and telephone. The power activities of Japan, however, do not belong to the Government, but are under Government regulation. Nevertheless all the electrical equipment that is bought by the Japanese Government is tested by the Government. I was greatly impressed. For example, they have a laboratory on the outskirts of Tokyo and another one at Osaka. In the laboratory at Tokyo they had testing: equipment of all kinds and over 1,000 men were employed in that kind of work. That gives you an idea of the thoroughness with which they go into anything which they agree upon to do. When it is agreed that the electrical equipment that the Japanese Government buys will be tested, it is tested. I have a feeling that if we were charged with the testing of all the equipment that the Government buys'we would be terribly swamped. Japan has a population of about 59,000,000 in the island, while we have some 120,000,000. On the same basis we would require 2,000 or more persons to do the testing in this country. I am happy to say that we do not have to do the work. The weights and measures work of Japan is centralized and the standards work is carried out in cooperation with industry; but the Government has the last say, and that places it in a very powerful position. Any program they wish to carry out can be accomplished.

It is interesting to know that there have been three systems of weights and measures in use in Japan-the Japanese system, the English system, and the metric system. Originally they had only the Japanese system; then the English and the metric systems were added about the same time-I think in 1919. Then in the Government they tried an experiment. The war department adopted one system and the navy department the other. I think it was the navy which operated under the English system and the war department which operated under the metric system. They tried in this way to make a comparison, and they have been going on on that basis.

A professor of mechanical engineering of Tokyo explained the complexity of the present conditions. He stated that in the case of 
an ordinary I bar, which is used in building construction, it was common practice, for example, to put the length of the I bar, let us say, in the English system, the height and width of the I bar in the Japanese system, and the thickness of the metal employed in the inetric system; as a result the Japanese engineer had to work on the same piece of metal in three systems. The situation now is that in 1924 the Japanese Imperial Diet passed a law making the metric system compulsory and the sole system, to become effective in 1934 .

That is in brief what I have to report in relation to weights and measures that $I$ saw in Japan. I might also state that they are very skillful in making up packages to sell. I believe they are the best packers there are. You can buy a dried dinner-dinner No. 4 or dinner No. 6 or dinner No. 20-in which everything to make up the dinner, including the materials for soup and dessert, are in one package-which is carrying simplicity right into the home.

The Engineering Congress was very well attended, indeed, by several hundred foreign engineers and several hundred Japanese; there were 800 papers, this bureau presenting a paper on precision measurements and instruments for measurements of length. That congress was a very great success, indeed, and of course the Japanese were very proud in having entertained the first engineering congress held in the East.

Now, gentlemen, I have perhaps taken more than my allotted share in the discussion of the work of this conference, the work going on, and in referring to my visit to Japan. I want to say that I believe these conferences are of the very greatest use to the members concerned, and I want to say to the new members that you have an opportunity to get acquainted with the old members and what is going on at the bureau. Some of the best results are from our informal contacts; and, in addition to the printed program, if any of you have matters which you want to bring up, arrangements may be made to have them discussed in the conference.

We will now proceed to the regular order of business.

\section{ABSTRACTS OF STATE REPORTS ${ }^{1}$}

\section{- ALABAMA}

By R. C. SHARP, Chief Inspector of Weights and Measures, Birmingham

Mr. Sharp reported that H. S. Holloway had recently succeeded H. L. Flurry as chief of the State division of weights and measures, but that Mr. Holloway had been unable to make arrangements to be present at the conference.

\section{CALIFORNIA ${ }^{2}$}

\section{By J. S. CASEY, Chief, State Division of Weights and Measures}

$\mathrm{Mr}$. Casey reported that his division was in a flourishing condition, with adequate funds, added equipment, and a well-trained personnel. Charged with the enforcement of numerous statutes in addition to the weights and measures law, the division has enough inspectors, so that each may specialize in a particular branch of

1 For convenience of reference these reports have been arranged in alphabetical order throughout.

2 This report was submitted through C. M. Fuller and was read to the conference by him. 
the work. Mr. Casey noted the good results which have followed the State weights and measures conference held in October, 1929.

\section{CONNECTICUT}

By Pнinх T. Pilox, State Inspector of Weights and Measures

Mr. Pilon stated that there had been an increase of over 14 per cent in the number of inspections as compared with the record of the previous year. The attitude of the business interests of the State toward weights and measures regulation was said to be particularly friendly, with satisfactory conditions prevailing in all sections. A program to strengthen the weights and measures statutes is planned for the next legislature, which will convene in January.

\section{DELAWARE}

(An official was in attendance from Delaware, but no report from this State was presented to the conference.)

\section{DISTRICT OF COLUMBIA}

(Officials were in attendance from the District of Columbia, but no report from the District was presented to the conference.)

\section{GEORGIA}

\section{By S. H. Wilson. State Oil Chemist}

Mr. Wilson reported that the general weights and measures bill which had been prepared for introduction at the last legislative session was not introduced because of local conditions which made such action inadvisable; this bill, which follows the model State law of the conference, will, however, be offered at the first favorable opportunity. Six inspectors now devote all of their time to the inspection of gasoline-dispensing devices under a law requiring that such devices be tested once every three months.

\section{IDAHO}

By Eriest J. Crouch, Director, State Bureau of Weights and Measures

Mr. Crouch outlined the history of the Idaho weights and measures statutes, stating that it has only been since 1923 that active inspection has been carried on. He said that the laws are considered inadequate for proper supervision, and that his division is handicapped by insufficient funds. Several efforts have been made to secure the enactment of a comprehensive law based upon the model law of the conference, but so far these efforts have been unsuccessful. In so far as possible, the recommendations of the conference as to specifications and tolerances are being followed out in the work of the division.

\section{ILLINOIS}

By W. T. FosserT, State Superintendent of Standards

Mr. Fossett reported that there are now 12 State inspectors of standards carrying on field work throughout the State; these men are supplied with new automobile trucks for the transportation of 
their equipment. Seventeen cities are now required by statute to have local inspectors, and this number will be increased as a result of the last census. Mr. Fossett commented upon the success of the State weights and measure conference held in March. There has been no new legislation enacted recently.

The Chatrman. We have a communication from William $F$. Cluett, chief deputy inspector of weights and measures of the city of Chicago, who is one of the oldest members of the conference and who is unfortunately unable to be present at this conference for the first time in many years. This communication reads as follows:

To Doctor Burgess, president, F. S. Holbrook, secretary, officers, members, and guests of the Twenty-third National Conference on Weights and Measures: Greetings. May you have the best, liveliest, and most educational weights and measures conference in your history, is the wish of William F. Cluett, resting on the side lines because of illness.

(Signed)

William F. Cluett.

INDIANA

By I. L. Miller, State Commissioner of Weights and Measures

Mr. Miller described briefly the new outfit for the testing of largecapacity scales, just acquired by his department; this equipment will carry 6,000 pounds of standard weights, and will have a gross weight of about $71 / 2$ tons. The 500-pound weights comprising the bulk of the test-weight load will be handled on the scale platform by means of a 2-wheeled cart. Mr. Miller also commented upon a case recently begun against his department in connection with the standard-weight bread law.

KENTUCKY

(An official was in attendance from Kentucky, but no report from this State was presented to the conference.)

\section{MAINE}

(Officials were in attendance from Maine, but no report from this State was presented to the conference.)

\section{MARYLAND}

By S. T. Griffitm, Chief, Division of Weights and Measures, Baltimore

Mr. Griffith stated that the efforts to secure the passage of a comprehensive weights and measures law for the entire State, which met with defeat a year ago, would be continued, and that with the assistance of the State board of agriculture and department of markets it was believed that success would eventually be achieved. He commented briefly on the administration of weights and measures in the city of Baltimore, stating that the conference recommendations as to specifications and tolerances are largely followed. 
By Francis Merenth, Director, Statc Division of Standards

Mr. Meredith reported that luring the year a considerable amount of time has been devoted to examinations for type approval-gasoline puinps, meters, metering systems, and grease-measuring devices having predominated in this work. Some 6,000 licenses were also issued under the several licensing laws administered by the division. An appropriation of $\$ 7,000$ was made by the last legislature for the procurement and equipping of a special truck to be used for the testing of large-capacity scales.

\section{MICHIGAN}

By Petrer D. Dukesherer, Director staie Bureau of Foods and Standards

Mr. Dukesherer reviewed the history of weights and measures legislation in Michigan and compared the condition of commercial equipment during the first years of active enforcement with its present condition, as revealed by the records of inspection results, noting the tremendous improvement which has taken place. Through a cooperative arrangement with the State board of pharmacy, inspectors of that office test the weighing and measuring equipment in all drug stores. It was stated that the State highway department plans to install ten 60 -ton scales for checking loaded trucks on the highways.

NEW HAMPSHIRE

(An official was in attendance from New Hampshire, but no report from this State was presented to the conference.)

\section{NEW JERSEY}

\section{By J. HARRY Foley, State Superintendent of Weights and Measures}

Mr. Foley gave a general résumé of the activities of his department. He said that examinations for type approval had consumed more time than heretofore, devices used for the dispensing of petroleum products predominating among those submitted. A program of educational work among the people of the State has been vigorously carried out. During the year over 800,000 yards of thread have been remeasured under the thread law enacted several years ago. Numerous special investigations have been conducted, among which Mr. Foley mentioned particularly those on butter, potatoes, and grapes.

\section{NEW YORK}

By C. P. NoRgord, Assistant Commissioner, State Department of Agriculture and Markets

Mr. Norgord outlined two important policies of the State bureau, as follows: First, since the bulk of the inspectional work in the State is performed by city and county officials, and the State force is very small, effort has been concentrated on raising the efficiency 
of local departments. Second, as to inspectional work performed by the State inspectors, emphasis is placed for considerable periods: upon one or two lines, with a parallel program of publicity; during the past year the emphasis has been on coal and gasoline. Mr. Norgord stated that excellent results had followed the plan of holding hearings at the department in the case of violations of the statutes.

\section{NORTH CAROLINA}

By WILLIAM H. RICHARDSON, Editor, Staie Department of Agriculture

Mr. Richardson reported that the license tax act of 1929, designed to provide revenue to carry on weights and measures supervision in the State in lieu of the inspection fees provided for by the earlier law, had not produced enough revenue to permit the work to be carried on as extensively as anticipated. He stated, however, that with the cooperation of some of the cities which have employed inspectors and the assistance which the State department had been able to render much good work had been accomplished.

\section{OHIO}

\section{By J. C. TINIEr, Deputy State Scaler of Weights and Measures}

Mr. Tinkey advised that supervision of weights and measures work in Ohio is now under the division of feeds and fertilizers of the department of agriculture, D. M. Odaffer being chief of that division. He commented upon a successful State conference held last December, and upon the continuance of district conferences throughout the State. The inspectional work of the local and State departments was briefly summarized, and it was stated that the triennial inspection of local standards was nearing completion; the importance of this latter work was demonstrated by the fact that of the apparatus examined 39 per cent required adjustment and over 6 per cent was found unfit for use.

\section{PENNSYLVANIA}

By Albert B. SmIth, Director State Burcau of Standard Weights and Measures

Mr. Smith reported that during the year special attention had been paid to the testing of gasoline dispensing equipment and oil bottles, with the result that marked improvement in conditions had been brought about. Special efforts had also been directed toward milk bottles, with particular reference to the capacity point and the elimination, under a new law, of bottles of capacities of 5,10 , and 12 fluid ounces. Mr. Smith mentioned the steps which had been taken by the State bureau in certain jurisdictions where the local officials had become lax in the discharge of their duties.

\section{RHODE ISLAND}

By Louis B. Jones, Superintendent of Weights and, Measures, Providence

Mr. Jones reported only for his city, in which the weights and measures personnel consists of the superintendent and four deputies. He briefly summarized the inspectional work of the department, noting that the mechanical condition of the commercial equipment in use was practically the same as in the previous year. 
TWN NESSEE

By 'T. F. MAHover, Sealer of Weights and Measures, Chattanooga

Mr. Mahoney reported that his State had recently undertaken the testing of gasoline for quality, this work being carried on in all parts of the State by means of a traveling laboratory mounted on a truck. While the chemist is making his analyses for quality in a given city or town, an inspector of weights and measures, who also accompanies the truck, tests all of the gasoline-measuring devices in use.

\section{TEXAS}

By V. A. Stovall, Chief Inspector, State Division of Weights and Measures

Mr. Stovall discussed the efforts of his division to secure additional legislation during the past year, which were successful in only one instance, an amendment to the general penalty section whereby this was materially strengthened. Bills to amend the public weighers law, to provide for the licensing of operators of gasoline dispensing devices, and to provide additional revenue for the department through the levying of an assessment of 2 cents on each bale of cotton at the compresses, all failed of passage.

\section{UTAH}

By B. D. NeвEкER. Superintendent of Weights and Measures and Oil Inspection, Salt Lake City

Mr. Nebeker spoke briefiy on the organization of weights and measures supervision in Utah, and stated that progress was being effected notwithstanding numerous handicaps. In so far as practicable, the conference recommendations as to specifications and tolerances are being followed by the State and local offices. Mr. Nebeker also commented upon the problem of gasoline shrinkage as affected by the temperatures prevailing at the time of measurement.

\section{ANNOUNCEIIENT AND MITION}

The Chatrvar. The time for recess is approaching, and before we do recess the secretary, Mr. Holbrook, has an announcement to make.

Mr. Holbrook. I wish to state that two reports of the committee on specifications and tolerances are now in mimeographed form and may be obtained for consultation before these matters come before the conference for action. One of these is the report on greasemeasuring devices, which will be considered this afternoon, and the other is the report on odometers, which will be considered to-morrow morning. Copies of these reports are now on the desk.

Mr. Ragland. Mr. Chairman, I move that the secretary be instructed to send to Mr. Cluett, of Chicago, some flowers and a suitable telegram, expressing the sympathy of this conference in his illness.

(The motion was seconded, the question was taken, and the motion was agreed to.)

(At this point, at 1 o'clock p. m., the conference took a recess until 2 o'clock p. m.) 


\section{SECOND SESSION (AFTERNOON OF TUESDAY, JUNE 3, 1930)}

The conference reassembled at 2.05 o'clock p. m., Dr. George K. Burgess, president, in the chair.

\section{ABSTRACTS OF STATE REPORTS-Continued}

\section{VERMONT}

By H. N. Davis, Deputy State Commissioner of Weights and Measures

Mr. Davis reported the promulgation of a regulation requiring antidrain nozzles on meter pumps and of specifications and tolerances for these devices. He said that his department had been spending considerable time in checking maple-sugar sirup, stating in this connection that Vermont produces 80 per cent of all the maple products made in New England. In general, he reported progress and satisfactory conditions throughout the State.

\section{VIRGINIA}

By J. H. MEEK, Director State Division of Markets

Mr. Meek stated that the principal weights and measures activities of his division were along the line of cooperation with the local sealers of the State. A program of testing large-capacity scales, begun two years ago, has produced gratifying results in the repair and replacement of incorrect equipment; in the trucking sections of the State a considerable number of produce barrels have been measured; recently an extensive program of testing gasoline-measuring devices has been inaugurated. The State division has also done considerable work in counties where there are no local sealers.

WEST VIRGINIA ${ }^{3}$

By HowARD S. JARReTt, State Commissioner of Weights and Measures

Mr. Jarrett said that because of inactivity in the coal business the testing of mine scales had occupied less time than usual, and his inspectors had been able to devote more time to other phases of weights and measures work; he particularly mentioned their activity in the examination of equipment in retail stores, the checking of package goods, and the investigation of numerous complaints. Mr. Jarrett also presented an interesting analysis of the gasoline equip. ment situation, pointing out that the amount of equipment in use is increasing faster than the sales of gasoline.

${ }^{3}$ This report was read to the conference by P. T. Sullivan. 


\section{WISCONSIN}

By GEORGE WARNer, Chief State Inspector of Weights and Measures

Mr. Warner confined his report to a discussion of four weights and measures bills introduced into the last legislature, two of which became law. Under a consolidation statute, the State weights and measures organization is now a part of the newly created department of agriculture and markets, although for practical purposes the work of the organization is not affected. The statute relating to Babcock glassware was strengthened, making it easier to secure convictions for violations. A bill to establish a standard for a cord of wood and a bill to make the weights and measures inspectors regular members of a State constabulary failed of passage.

\section{ABSTRACTS OF REPORTS OF REPRESENTATIVES OF STATE ASSO- CIATIONS OF WEIGHTS AND MEASURES OFFICIALS}

\section{INDIANA ASSOCIATION OF INSPECTORS OF WEIGHTS AND MEASURES}

By I. L. MILleR, State Commissioner of Weights and Measures

Mr. Miller reported that with very few exceptions the Indiana association had met regularly each year since 1911. Owing to a conflict of dates with another State association the 1930 meeting of the Indiana organization has been postponed from June to September.

\section{MASSACHUSETTS ASSOCIATION OF SEALERS OF IVEIGHTS AND MEASURES}

By HoMer J. MeLIDY, Deputy Sealer of Weights and Measures, Worcester

Mr. Melidy noted an increase in the membership of the association as compared with the records of a year ago. He stated that the meetings of the association are attended not only by weights and measures officials but also by the public. One of the principal activities of the Massachusetts association is in connection with the passage of suitable weights and measures legislation.

MICHIGAN STATE, COUNTY, AND CITY SEALERS' ASSOCIATION

By GeOrge W. MAHN, Sealer of Weights and Measures, City and County of Saginaw

Mr. Mahn extended a general invitation to attend the seventeenth annual meeting of the association to be held in Benton Harbor in June, and gave a résumé of the program which had been arranged for the meeting.

\section{NEW JERSEY WEIGHTS AND MEASURES ASSOCIATION}

By JosepH G. Rogers, Assistant State Superintendent of Weights and Measures

Mr. Rogers announced that the next meeting of the association would be held in September at Asbury Park, and issued a general invitation to attend the sessions. He gave a detailed report of the matters considered at the midwinter meeting of the association, held in Trenton in February, and recommended that other associations adopt this idea of a short executive session to be held between the regular annual meetings of their organization. 
NEW YORK STATE ASSOCIATION OF SEALERS OF WEIGHTS AND MEASLRES

By J. H. StEphensox, Sealer of Weights and Measures, Rochester

Mr. Stephenson extended a general invitation to attend the sessions of the twenty-third meeting of the association, to be held in Niagara Falls in July.

\section{OHIO SEALERS' ASSOCIATION}

By J. C. Trixer, Deputy State Sealer of Weights and Measures

Mr. Tinkey said that the association was interested in securing a revision of the State weights and measures statutes, and has a committee working toward that end. Last year the association indorsed the standardization of package goods in units of multiples and submultiples of the pound and gallon. The next meeting of the association will be held in December.

The Chairurax. It occurs to the chair that these reports from State associations show the advantages of forming such organizations in the several States for the purpose of fostering the work of weights and measures supervision and stimulating the interest of those engaged in this work. I think that all of the States which have such associations should encourage the formation of similar associations in the other States.

\section{NOTES ON GREASE-MEASURING DEVICES}

By RALPH W. SMith, Bureau of Standards

I think it is a fact that up to the present, the number of weights and measures officiais who hare made a study of grease-measuring devices is relatively small. It therefore appears appropriate at this time to consider briefly the various types of these devices which are at present on the market. I hope that this résumé of the principles of operation of the various types which have been developed up to the present time will be of interest and assistance to the conference.

What I shall say is based upon the latest information which we have been able to secure upon this subject. We have endeavored to learn the names of all manufacturers of grease-measuring devices and the character of the product which they make. In this re believe that we have been fairly successful. We have learned that some companies previously making these devices have discontinued their manufacture, that some companies are modifying their design in view of the conference code of specifications and tolerances, and that some manufacturers have just entered or are about to enter this field.

At the outset I believe it is well to mention again, and to emphasize, that the conference code for grease-measuring devices concerns itself only with those instruments intended to dispense greases and oils for automobile transmissions and differentials, and to register the amount of grease or oil dispensed. The large group of devices known variously as "pressure lubricators," "chassis lubricators," "grease guns," etc., used for the lubrication under relatively high pressure of bearings and other moring parts, is excluded from 
the conference code and is of no direct official interest to the weights and measures officer because the amount of grease or oil dispensed does not enter into the charge assessed for such a greasing operation. The cost of the lubricant is relatively unimportant compared with the cost of the servicing operation, and no direct charge is made for the lubricant itself. You will realize that the reverse is true in the case of what we call a "grease-measuring" device, where the cost of the service is secondary, the cost of the lubricant is the important item, and the charge for the greasing operation is fixed by the amount of lubricant dispensed. In what follows, therefore, I will confine myself to what we have defined in the conference code as a grease-measuring device. Let me also make it plain that no effort has been made to determine how many of the units discussed are in compliance with the requirements of the conference code.

The results of our survey indicate that there are now made three principal types of grease-measuring devices-the meter type, the gear type, and the piston type. There is one common characteristic of all of these types and that is that the quantity is determined by a measuring operation of some sort. You will remember that the conference code specifically exempts grease-weighing devices which may be used for the same purpose as the grease-measuring device. We know of no unit being made which utilizes a weighing operation to determine the amount of grease dispensed, but such a unit may be developed and, if so, a number of the provisions of our present code would be inapplicable to such a device; it was therefore considered appropriate to exclude from the provisions of the code a greasedispensing unit based upon the gravimetric principle, leaving the consideration of this type to such time as it may make its appearance in the commercial field. It may not be out of place to repeat that the primary reason for requiring that grease-measuring devices be designed to indicate and deliver in terms of pints rather than in terms of pounds was that these devices universally measure rather than weigh and that if pound indications had been permitted this would have introduced a series of weights and measures enforcement difficulties in addition to being fundamentally inconsistent and unsound.

Reverting now for brief consideration to the three types of greasemeasuring devices which I have mentioned-meter, gear, and pistonI would say, first, that my conception of a meter type is one in which the lubricant passes through an automatic measuring element called a meter and by its passage causes registration of the amount dispensed; in other words, by "meter" I mean "flow meter" in its commonly accepted sense. Some manufacturers appear to use the term " meter" in referring to a mere counting element, such as a tallying device which is distinctly separate from the measuring element and which records the movement or the number of operation cycles of a pistonand-cylinder combination; I do not consider such usage accurate or desirable. We find that there are 10 manufacturers who market devices embodying "meters" according to my definition; all of these utilize air pressure to force the lubricant through the measuring element, and one manufacturer also has a unit in which an electricallydriven pump performs this function. On 6 of these units the meters indicate up to 8 pints, 1 indicates up to 10 pints, and 3 indicate up $24342^{\circ}-31-3$ 
to 12 pints; 6 of the units are or may be equipped with totalizing counters; 1 of these units has an automatic valve to release the air pressure when the supply of lubricant is exhausted.

We find only one unit constructed on the "gear" principle. Here the lubricant is expelled by being drawn between and forced through meshing gears, which are revolved by means of a hand crank. A counter reading to $51 / 2$ pints is connected with the measuring gears. This unit is provided with an automatic locking mechanism to make it inoperative when the supply of lubricant is exhausted.

In the piston-and-cylinder type we find one in which the entire "bottle," or container for the lubricant, is the cylinder, with a large piston driven by air pressure and connected to an indicating mechanism by means of a spiral metal "ribbon." The tallying device. or "job indicator," on this unit will indicate up to 10 pints, and there is also a "supply indicator" to show the amount of lubricant remaining in the unit at all times; as a result of its general design this unit necessarily becomes inoperative when the supply of lubricant is exhausted.

There appear to be five manufacturers making units in which a relatively small-capacity cylinder is connected with a container holding the lubricant, the pistons being operated by hand cranks and having tallying devices to count the piston strokes; the maximum registration on the counters is 5 or 8 pints. On one of these units there is an indicator designed to show before each discharge stroke that the piston is properly filled; warning of exhaustion of the supply of lubricant is given through failure of the indication just mentioned.

There remains to be mentioned only that class of piston-type dispensers in which no effort is made to register the number of piston strokes comprising delivery to an individual customer; the original types of so-called. "grease buckets," "grease paks," "bucket pumps," etc., are in this class. Many of these are in use throughout the country, and it is probable that there are numerous manufacturers of this simple type whose names have not come to our attention. Some manufacturers of whom we happen to know seem inclined not to modify their devices to conform to the requirements of the conference code, while others are endeavoring to do so.

In any consideration of grease-measuring devices the question naturally arises as to how these devices may best be tested for accuracy by the weights and measures official. I do not propose to go into an exhaustive discussion of testing methods for these instruments nor to offer any definite test routine. Some general comments, however, may be of assistance to you when you decide to undertake seriously the regular examination of grease-measuring devices.

I realize, as, I am sure, do all of vou who have attempted to test one of these devices, that the testing operation is attended with certain difficulties and annoyances not met with in the examination of many of the weighing or measuring devices which you are called upon to test. The units must be tested when filled with the lubricant which they are intended to dispense, and this lubricant itself must be the testing medium. The nature of greases and oils makes them somewhat inconvenient and unpleasant to handle, the operation is not a particularly clean one, and the whole test may be somewhat inelegantly but nevertheless truthfully characterized as 
"messy." The problem, then, is to make the best of an unpleasant situation, without sacrificing any essential elements of the test or jeopardizing the accuracy of the results.

Since the unit indicates in terms of pints, its discharge must be measured volumetrically or a conversion must be made into volumetric units. It is obvious that the inspector can not afford to use his regular standard volumetric measures direct in the test of a grease-measuring device, because these standards must be kept clean at all times to avoid contaminating any capacity measures which may be compared with them. One method which may be followed for volumetric testing is to determine the accuracy of one or more ordinary commercial capacity measures by the use of the inspector's standards and then make the discharge from the grease-measuring device into the commercial measures; in such a case it will be necessary that the commercial measures be wiped out or otherwise cleaned between each observation so as to remove from the walls of the measures all of the adhering grease or oil. It is probable that in some places no difficulty will be experienced in borrowing from the station or garage operator the necessary number of commercial capacity measures to use as suggested. In other cases, however, it may be that there will only be available at the station or garage lubricating-oil measures of a type which would not be suitable for this use in that they are equipped with special spouts to facilitate crankcase filling. Here it would seem that the weights and measures official would be obliged to make his own provisions for carrying on the test of the grease-measuring device. To meet this situation some officials have proposed the use of paper containers such as the rigid or semirigid cups, buckets, and cartons manufactured for the dispensing of food products. Such containers when of lightweight material may be used but once, or at most only a few times, and are then to be discarded; to avoid distortion of such containers it would be necessary that a supporting form be used, similar to those used with ice-cream buckets. In the case of the heavier varieties of paper containers, however, they may repeatedly be cleaned between observations and used a considerable number of times before being: thrown away. It would be necessary, of course, that each such container used, whether of light or heavy material, be carefully tested by means of the inspector's standard measures because, when used as indicated, the paper container becomes the standard by which the grease-measuring device is directly tested, and its accuracy must have been established before such use.

As I see the matter, the greatest objection to the use of paper containers or commercial measures for the testing of grease-measuring devices is the determination of the error of delivery so that the tolerances may be applied. All of these units are relatively "insensitive," due to their broad tops. On account of the nature of the material involved in the test, it is obvious that the inspector can not utilize a small diameter graduate in applying the tolerance as is done in the case of measures being tested with water or other testing mediums of low viscosity. It is probable that it will be necessary for the inspector to determine by means of tests made with water, and to mark upon the inside of the measures or containers used to receive the discharge from the grease-measuring device, the height corresponding to the nominal capacity of the measure or container, 
and then to establish above or below this point lines corresponding to the maximum and minimum amounts allowable under the tolerances. He will then require that the grease-measuring device be so adjusted as to make delireries within these limits. This procedure is not a rery satisfactory one, hotrever, and a very high degree of accuracy is not to be anticipated from its use.

There is another method of testing the discharge from a greasemeasuring derice which is susceptible of higher precision of results and which aroids some of the difficulties noted abore. but which introduces one new factor as an essential element of the operation. I refer to the gravimetric or meighing method of testing the discharge, under which it first becomes necessary to determine the weight per pint of the testing medium: that is, of the oil or grease with which the unit under test is filled. In using this method the inspector must, of course, be prorided with a suitable scale. The inspector's regular 10-pound testing balance, used for the testing of counterpoise and other weights. is not, perhaps, particularly well suited for use in connection with the testing of grease-measuring derices, on account of the large number of loose standard weights which it would be necessary continuously to utilize, and on account of the size of the container used to receire the lubricant discharged from the derice under test. Some officials already hare small scales which they use for the check reighing of package goods, and others could undoubtedly procure these if considered expedient; these scales should prore entirely satisfactory for use in testing a grease-measuring derice.

To determine the weight per unit rolume of the lubricant being dispensed from the particular derice under examination, the inspector should be prorided with a substantial metal crlindrical standard haring a capacity of 2 or 4 pints, preferably the latter; the capacity of this measure should be defined by the top edge of the measure. Haring first determined the reight of this measure when empty, or haring " balanced it out" on the scale, the measure is filled lerel full of the lubricant and the net reight of the measured amount of lubricant determined: from this figure the reight per pint is readily found. This measure may then be emptied and cleaned, and need not be used again until the test of another grease-measuring derice is undertaken.

Any convenient container may now be used to receive the discharge from the grease-measuring device. and this container need not be cleaned betreen successive observations, because its tare meight can be determined prior to each discharge from the grease-measuring derice and the net weight of each discharge readily computed from this tare weight and gross meight after discharge, or the container may be "balanced out " before each discharge and the amount of the discharge weighed net. From the weight per pint of lubricant the inspector can readily compute the weight representing the tolerance for a delirery of any nominal amount. and this may be easily applied and a decision quickly arrired at as to compliance or noncompliance with the tolerances. "It is the ease with which errors of discharge may be computed and tolerances applied by the weight method which particularly recommends this method orer the straight rolumetric methor in which it is necessary to determine elrors and apply tolerances volumetrically; the principal objection to the meight method 
is the necessity for accurate determinations of the weight per unit volume.

Experience may show that the inspector may with safety simplify the weight method of testing grease-measuring devices by eliminating the individual determinations of the weight per pint of the lubricant each time a test is undertaken, and proceeding upon values for this vital factor which have been determined in his office for lubricants of different grades and makes. Perhaps one series of values might be worked out for average summer temperatures, and another for the average temperatures which may be anticipated for spring: and fall; in winter testing, different grades of lubricant would be encountered as compared with those in use during the warmer portions of the year, and values for these might be worked out for a temperature corresponding to that of the average filling-station office or garage. I am not as yet prepared to recommend this method of procedure, because I do not know the magnitude of the errors which might be introduced; but if it can be shown that such errors are negligible, then there would be removed from the weight method of testing grease-measuring devices its principal objectionable feature.

In either the volumetric or gravimetric method of testing a greasemeasuring device it is recommencled that deliveries of at least 2 pints up to perhaps 4 or 5 pints be utilized, rather than deliveries of single pints. This recommendation is made because on a delivery of 4 pints, for example, the tolerance is approximately four times as great as on a 1-pint delivery and is susceptible of easier and more accurate application; another reason is that such deliveries will probably represent more nearly average performance of the device than a delivery of a single pint. If it is desired to check the accuracy of the device on the delivery of the first indicated pint, cause the device to discharge several "initial" pints, averaging the error on the total of these deliveries to arrive at the error of the initial pint. Methods of making other combination deliveries and of testing the discharge of the device at various points throughout its range whenever this is necessitated by the type of device under examination, will be obvious without detailed explanation.

DISCUSSION OF ABOVE PAPER

The Chatrmax. In inviting discussion of this paper, the chair would state that it is the practice of the conference to invite discussion from anyone present. Does anyone wish to discuss this paper?

Mr. Ragland. Mr. President, I was deeply interested in this rather technical paper presented by Mr. Smith. I think it was good, but he did not mention two things that I think should have been mentioned. In relation to chassis lubrication, we do not care about it. They have all kinds of guns to do it. Mr. Smith said that the amount of grease or oil dispensed does not fix the charge assessed for such greasing operation as the cost of the lubricant was relatively unimportant compared with the cost of the servicing operation. In relation to greasing differentials and transmissions, I may say that it is not the cost of the material that goes in but it is the cost of the material that does not go in which is important. The cost of the grease is very small. Grease is obtainable at anywhere from 3 to 8 cents a pound. 
That does not make much difference in the cost of the job, but it makes a world of difference if the grease does not go into the transmission and you have stripped gears, and all kinds of trouble. That is what $I$ am considering. If $I$ have a bad tooth $I$ can not see it, but when I go to the dentist I want him to tell me what is going on.

When we go to a service station we supply our deputies with halfpint, pint, and quart containers. They go in and turn a handle and if the device is correct they know it. We never would make as many inspections if we had to use gasoline everywhere to clean the measures. But it is a simple affair to carry these extra containers, and you can tell immediately whether a pump is correct or not. You do not dirty your hands and you do not have to have scales. We can do much quicker work, insure more inspections, and thereby assure people of getting full measure in grease deliveries.

Mr. Rogers. Mr. Chairman, testing grease-measuring devices is a dirty job as everybody knows, but we found out an advantageous method. There is a type of cylindrical container which we have approved for various measurements of ice creams and liquids. We find those containers very well within the limits of tolerance at all times, and so they can be used for testing without detriment to accuracy. A number of these can be secured-they come in half-pints, pints, and quarts, just the sizes in which the grease-measuring devices are graduated. By using these you make a test that is very accurate and you will not have all that cleaning of a good standard to go through each time.

Mr. SAYBolt. Mr. President, just a point for Mr. Smith's consideration. His paper was very valuable. The point I would like to make is that if this gravimetric method be pursued, based on volumetrically filling a container, it must be remembered that there is always a certain amount of aeration that will apply in plastic materials, and some method would have to be developed to eliminate this aeration.

The Chairiran. I would like to say in relation to our next item that many of the weights and measures officials here do not have any äirect supervision over cotton. However, cotton is of tremendous importance in the Southern States, and the standardization effort, which will be discussed by Mr. Palmer, represents a large program, which should be of interest to all weights and measures officials in this conference.

\section{THE SALE OF COTTON BY NET WEIGHT AND THE STANDARDIZATION OF THE BALE}

By ARthur W. Palmer, Chief, Division of Cotton Marketing, Bureau of Agricultural Economics, United States Department of Agriculture

The cotton crop of the world is marketed in containers of different kinds, but in the United States the package unit of lint cotton is the bale. This has been true with no observed exception since the virtual disappearance from production of sea-island cotton, a select part of which was until about 10 years ago sent to the mills in bags.

The American bale is of two general types, one the round bale and the other the so-called square bale. There are substantial differences between the two. The round bale is packaged in a round-bale press 
which is attached to the gin in place of the usual square press box. A few round presses turn out bales of 500 pounds, but the usual round bale is about 250 pounds, or half the weight of the square bale. It is 35 inches in height, 22 inches in diameter, has a density of about 28 pounds a cubic foot, and is completely covered with about $2 \frac{1}{2}$ pounds of closely woven burlap cloth. The weight of covering is usually calculated without controversy at 1 per cent of the gross weight.

The story of the round bale is one of the romantic chapters in American cotton history. From nearly a million running bales reported by the Census Bureau in 1902 the round-bale production fell to about 58,000 in 1914, a year in which the crop was of record size. The present round-bale press is a development of the last 20 years, during which it has undergone modification and improvement. Production of round bales has shown a rather consistent increase since 1914. In that year round-bale production was 58,000 running bales, and counting round as half bales was about two-tenths of 1 per cent of the crop. By 1928 it had reached about 675,000 running bales, or $2 \frac{3}{10}$ per cent of the crop.

Many advantages are claimed for the round bale. It occupies, however, a position which is somewhat special owing to the fact that the press patents have been closely held and that distribution of the round-bale production has rested very largely in the hands of those responsible for its development. Recently the round-bale press, of which formerly only the use was licensed, has been offered for sale. Were, in addition, a more universal market to develop for cotton in this form, the round-bale package would doubtless command a wider interest. The remaining discussion relates to the square bale, which is the form in which about 97 to 98 per cent of the crop is packaged at the present time.

The square bale as it is originally formed at the gin is variously described as a gin bale, a country bale, or a flat bale. The grower brings to the gin a load of seed cotton which has been weighed as picked and which is calculated to gin out one, two, or more even bales without overplus. The wagonload is weighed, and the cotton is generally drawn by suction into the gin. If the load contains more than one bale the ginner undertakes to switch the flow of cotton from one press box to another so as to make the bales of about even weight. In general, the effort is to make a bale which weighs about 500 pounds gross, but this is only approximate. In a study made in 1924-25 bales were found to vary from 300 to 700 pounds. Of about 6,000 bales examined in Texas, approximately 79 per cent fell in the range 450 to 550 pounds, with about 14 per cent heavier than 550 pounds and 7 per cent lighter than 450 pounds. Of 2,061 bales examined in Georgia, about 58 per cent fell in the range 450 to 550 pounds, with 12 per cent heavier than 550 pounds and 30 per cent lighter than 450 pounds. In Mississippi, of about 2,000 bales examined, 45 per cent fell within the range, 14 per cent above, and 41 per cent below.

The gin bale takes the dimensions of the press box and comes out about 54 inches long, 27 inches in thickness, and 48 inches in breadth. With pressures ordinarily obtainable, the density is about 12 to 15 pounds to the cubic foot of volume. The bale is covered on two of its sides and on the ends with a covering usually of heavy jute cloth, cut into two strips, each 3 yards, more or less, in length. It is bound 
sometimes with five, but usually with six ties, ordinarily of 19 to $191 / 2$ gage steel, $\frac{15}{16}$ of an inch wide and about 111/2 feet long, weighing sometimes 2 pounds each, but customarily $1 \frac{1}{2}$ pounds. The total weight of ties on the gin bale thus closely approximates 9 pounds. 'The weight of bagging aims generally at about 12 pounds, but may run from 5 to 20 pounds. Total tare weight of the gin bale-that is to say, the weight of the covering materials-has been rather traditionally set by the markets at 21 pounds, but it often varies several pounds either way from this figure.

As the bale runs the market gauntlet to the mill it undergoes sampling from time to time. In the sampling operation the bagging between the bands is cut and several layers of lint are pulled out.

To economize in transportation costs, gin bales are assembled near their points of origin at compresses where they undergo total pressures ranging up to about 2,000 tons. In this process their volume is reduced by about one-half. There are two degrees of compression, the so-called standard compression, and high compression. The standard compressed bale is elongated to about 56 inches, widened to about 28 inches, but reduced in thickness to about 18 inches. Its density is increased to about 22 to 28 pounds the cubic foot. It retains its original bagging but is given eight bands. These bands are shortened to $81 / 2$ feet, but the increase in number with the buckles keeps the total weight of bands at about 9 pounds. As a measure of protection and to reduce fire hazards, sample holes in the bagging are covered with patches which in most cases are applied to either side. The total weight of patches varies but usually ranges from 4 to 8 pounds.

Cotton which reaches the ports destined for export shipment is often further compressed to high density to take advantage of lower ocean freight rates. The high density compression pressures are about the same as for standard density compression, but by closing the press on the ends and sides the bale is narrowed a few inches and molded into a more symmetrical and substantial package. At the same time its density is increased to about 28 to 40 pounds the cubic foot, depending upon its weight. The original bagging is retained. Patches may be changed or added at this time. The highdensity bale is given nine ties which are shortened to $71 / 2$ feet and their total weight remains still very close to 9 pounds, equalling the weight of the six bands on the gin bale and of the eight bands on the standard compressed bale.

Although cotton to the value of a billion and a quarter to a billion and a half dollars goes to market every year in square bales, the square-bale package is not in step with the rhythm of American progress. In a rough way it serves its purpose but its weaknesses continue to be, as for many years past, the subject of friendly reproach from our customers in overseas markets. Its rents and tatters and soiled contents in the company of neater-dressed bales from other countries are an embarrassment to ourselves.

That the packaging of our raw cotton presents a genuine problem has long been realized. Its various phases have had attention of capable students from time to time in the past, and certain recognized improvements have been made. Among these improvements should be mentioned standardization of the dimensions of gin press 
boxes during the World War. The development of high-density compression, which so far as is yet known is accomplished without injury to the spinning properties of the fiber, is another.

And yet, notwithstanding the study and the efforts that have been given to the problem, the square bale taken by and large falls short of being a satisfactory package. Some of its shortcomings, in particular, are:

First, inadequate protection of the contents due to the use of bagging materials which fail to withstand the wear and tear of shipment, resulting in waste and damage of the contents.

Second, ragged unattractiveness of appearance due to the same causes.

Third, lack of uniformity in the weight of tare, resulting in uncertainty of the actual net weight of the contents and the consequent necessity of opening and stripping bales in the process of distribution.

Fourth, overtaring, due principally to the operation of present trading rules and the difficulty of determining under present conditions the weight of covering materials when once they have been applied to the bale.

Fifth, lack of even approximate uniformity in weight of contents.

To keep within the allowable time limits it has seemed desirable in this paper to hold the discussion rather strictly to questions of tare weights, with some reference also to protection of contents, and to leave for another occasion the consideration of bale weights, which present problems even more difficult.

From the descriptions given earlier it will be observed that since the weight of bands upon the bale remains for practical purposes uniform, whether the package be in the form of a gin bale or be compressed to standard density or to high density, the causes of variations in the weight of tare are due principally to the bagging and patches. Variation in the weight of bagging and patches is due to several different causes: First, the weight per yard of the materials used is variable. Figures obtained for the three years 1926, 1927, 1928 , indicate that in that period about 58 per cent of the crop was covered with new jute bagging weighing about 2 pounds a yard, about 11 per cent with rewoven bagging of approximately the same weight, about 25 per cent with reclaimed sugar-bag cloth weighing about $1 \%$ to $13 / 4$ pounds a yard, and about 6 per cent with secondhand bagging of very uncertain weight. Second, the yardage of bagging applied to the bale is variable. The ginner does not usually obtain bagging in the exact lengths in which it is to be applied to the bale, but in rolls from which the gin tender cuts for each bale two pieces, each supposed to be about 3 yards long but which may be considerably longer or shorter.

One of the most important contributing factors to variation in tare weights is found in the diversity of trade rules governing settlement weights and tare. In domestic business cotton is bought and sold on the basis of the gross weight of the bale. American mill rules allow 4.4 per cent of tare on uncompressed cotton and 4.8 per cent on compressed cotton, but in 1925 more than 20 different trade rules governing weight of tare were found besides the State laws, which in eight cases differed from each other. Cotton which is exported, 
however, is sold on a basis of its gross weight less 6 per cent. Methods of calculating tare are not uniform in various markets, but, in general, each 100 bales is required to have not to exceed 900 pounds of bands and a weight of bagging equal to $3 \frac{9}{16}$ per cent of the total weight of the 100 bales less the weight of the bands. One could go much further in detailing the intricacies of applying the rules on underweight bales or overtared shipments. The important thing to observe, however, is that when a bale of cotton which leaves the gin covered with 21 pounds, more or less, reaches a domestic mill in compressed form it may, if it weighs 500 pounds gross, carry 24 pounds of tare, but if it goes into export markets it may carry 26.2 pounds of tare. Franchise provisions in some of the markets and weighing technique allow this weight to be increased by another pound or more.

The differences in the weights of tare between the gin bale and the compressed bale as it reaches its mill destination either in this country or abroad is made up by the weight of patches which are added to the bale at the time of compressing. The added pounds of patches cost less than the equivalent weight of cotton sells for. The cheaper the patch, the greater the profit. So it happens that the diversity of tare rules in different markets has some curious consequences.

In examining these consequences it should be observed, first of all, that as a general proposition price competition in the cotton trade obliges the seller in any market to add the last pound of tare that the traffic will bear. Otherwise his competitor may be depended upon to do so, and by counting the profit in the patch weights put himself in position to undersell and get the business. The seller is handicapped, however, because unless he tests the tare of the cotton before shipping it he is not in position to know, possibly within several pounds, what the original tare weight of each bale was. Furthermore, he starts with bales of different weights, and even if the original covering on each bale were of uniform weight, the tare weights would not be equal percentages of the gross weights of the bales. The safe thing to do, therefore, is to add patches sufficiently heavy to be sure that he has availed himself of all his rights. If the seller in his effort to bring the tare weight up to the allowable maximum exceeds the limit, the buyer may, if he thinks fit, test the weight of tare and claim reimbursement for the excess. Testing the tare involves opening and stripping a part of the bales, usually 10 per cent, weighing the tare, and recompressing the bales. It is a tolerably expensive operation. Usually the arrangement is that if the buyer challenges and the bales prove not to be overtared the buyer must pay the expense of the test. If the shipment is overtared the seller pays this cost. In some markets it is rather customary for buyers as a protection to their interests to tare a large part of the shipments received. This is a charge upon distribution which the American cotton crop has to bear.

The entanglement of tare weights with sales prices may result also in another unfortunate competitive situation. Reputable merchants, whose business ethics hold them to strict observance of the rules, point out that, in competing for the business of a buyer who is tolerant of overtare, they can be undersold by a competitor who will shade his price and compensate himself by patching to exceed the tare limit. 
Another charge upon the handling of the crop is in the additional handling and storage charges which the diverse tare rules entail. As pointed out above, cotton going to export markets may carry heavier patches than that which goes to domestic mills. If unsold cotton is compressed to conserve storage space awaiting sale, the owner must decide whether to apply the lighter domestic patches or the heavier export patches. If light patches are put on and the cotton is exported, it generally has to stand the expense of being again compressed to have the heavier patches put on. If export patches are put on and the cotton is sold in this country it must sustain freight and other charges on excess weight.

To many people the task has seemed almost hopeless of this great industry's changing its habits so that in place of raggedness and damage cotton might have cover and protection; that in place of a selling system confused and involved with a tare procedure as complex as can be conceived there might be a clean-cut merchandising system for its distribution; that in place of adding to the crop an unneeded weight of covering the package could conform to its proper purpose, namely, to contain and protect its contents through the various processes of distribution. Others who have given thought to the problem feel that it is not incapable of solution if an intelligent attack is made upon its causes. Of these there are many who believe that a great part of the problem might be solved if all trading were based on net weights. There is, however, an understandable and, perhaps, justifiable hesitation on the part of cotton people to approve the net-weight principle unless coupled with some measure which will make obvious the actual tare on any bale of cotton at any time. This means either tare standards or the actual tare weight branded on each bale. Without detailing its disadvantages, the latter alternative may be dismissed as impracticable. Tare standards may, therefore, be regarded as a prerequisite to netweight trading.

There is reason to believe that the use of bagging and patches definitely conforming to fixed standards of weight ought to remove any necessity which may now exist for building up the gross weight of bales with more or heavier patches than are actually needed to afford protection to bale weights, with savings in the cost of materials, of freight, of insurance, of interest, and of adjusting and collecting buyers' claims for overtare. It should facilitate the handling of the cotton crop by permitting cotton to be compressed and stored without regard to the question of whether it is to be ultimately sent to domestic or foreign mills. It would seem to promote fair trading by putting sellers on even terms with each other so far as tare advantages are concerned. By protecting buyers from the impositions of overtare it should eliminate the expense of stripping and repressing bales in the taring process.

Whether a single fabric or even a single material could be prescribed as standard is open to some doubt. For a crop of $15,000,000$ bales, 90,000,000 yards of bagging and about $35,000,000$ yards of patches are required. Too severe limitation of covering materials would tend to raise the cost of the material designated as stanclard and increase the cost of covering the crop. There is no reason, however, why standards which would specify constructions, dimensions, 
and weights might not be fixed for several kinds of bagging materials, provided the materials were different enough to be positively and easily distinguishable.

With selling prices calculated on net weights there would be no advantage in using heavy bagging materials or disadvantage in using light bagging. Whichever material was the cheapest at any giren time would be used at that time, and the cost of baling the crop could follow the lines of greatest economy. Were bagging and patch standards to include in addition strength requirements, it is believed that the destruction of bagging which now cccurs so frequently in shipment could be minimized with consequent increase in protection of the contents and improved appearance of the package.

One factor which doubtless delays the change from gross to net weights is the apparent difficulty of making the transition. At whatever time tare standards might be established there would presumably be in the world upward of $2,500,000$ bales of American cotton of nonuniform covering and tare, the merchandizing of which on net weights would be impracticable. To effect the transition without undue hardship a sufficient period of time should be permitted to elapse between the time when all newly ginned cotton would carry standard tare and the time when net-weight trading became effective. Some modification of trading rules on American cotton throughout the world would also be necessary to accommodate the change. This: however, seems to offer no great difficulty inasmuch as representatives of foreign markets have already expressed their willingness to cooperate in this way whenever in this country we are ready to go forward.

The thought has occasionally been expressed that cotton growers being thoroughly accustomed to selling their cotton by gross weight would resent a change to net-weight selling which would compel the deduction of the weight of tare in the settlement. To the extent that growers are not informed of market practices and methods of calculating prices such an attitude might be expected. When, howerer, it is realized that the total money consideration given for a bale of cotton which is sold in export on its net weight is not less than that given in this country when bought on its gross weight; that the lack of standards for tare and gross weight selling are productive of unnecessary costs of distribution; and that every unnecessary item of cost reduces by that amount the share of the consumer's dollar which remains for him, the grower may be depended upon to appreciate the advantages of net weights. The simplification and sarings which tare standards and net-weight trading promise are sufficient to commend them to all who are interested in increasing cotton marketing efficiency and reducing its costs.

(During the presentation of this paper, Mr. Palmer illustrated by means of lantern slides a number of the matters discussed.)

DISCUSSION OF ABOTE PAPER

Mr. Sweener. Mr. Chairman, may I ask as to whether they weigh that cotton before or after it is pressed?

Mr. PALMER. The wagonload of cotton is weighed before it goes into the gin. The bale is pressed in the gin press, is then covered, and comes out; then it is weighed again. 
Mr. SweENer. Why could you not establish an approximate weight of material used in the tare, have a standard approximate weight for a bale of cotton, and require that a certain percentage or poundage be deducted for the tare. For instance, if the material you put on that cotton weighs 9 or 10 pounds, and if the bale weighed 400 pounds, gross, then you would immediately deauct 10 pounds for the tare and have a net weight of 390 pounds. Thereby you would have a uniform condition corering baled cotton.

Mr. Stovald. Has the United States Department of Agriculture ever conducted any experiments as to the moisture content of jute bagging? They tell us you can not wrap jute bagging without sprinkling it and when you put it in the sun it will lose as much as 4 or 5 pounds. Do you think that much moisture should go in jute bagging?

Mr. Palarer. I think not.

Mr. STovall. We get some bagging that looks as if it had been dipped.

The Chatrmas. In reference to the next paper I would remind the members of the conference that we have one or more papers from representatives of industries in which the weights and measures officials are especially concerned. Paul E. Hadlick is secretary of the division of marketing of the American Petroleum Institute. Prior to his connection with the institute he was associated for six years with the State Oil Men's Association of Minnesota; during that period he had frequent contact with the Minnesota department of weights and measures, and is, accordingly, no stranger to the activities or the viewpoint of the weights and measures officials. Mr. Hadlick will speak this afternoon with particular reference to regulations relating to grease-measuring devices.

\section{COOPERATION WITH WEIGHTS AND MEASURES OFFICIALS}

\section{By Pall E. Haduck, Representing the American Petroleum Institute}

Mr. Chairman and members of the conference, I come before you gentlemen to-day as a representative of the American Petroleum Institute. This institute, as you may know, represents 95 per cent of the refining capacity of the oil industry. It is the trade association of the oil industry with membership in every State in the Union. Having been in Minnesota and worked with Oscar Smith for many rears I know the burdens of the State inspectors, and we at all times have tried to help one another so that our burdens would be lightened, and I hope that the oil men throughout the country work with you gentlemen. If there is ever occasion where there seems to be unnecessary friction, I know you can call on me and I shall try to eliminate it at once, because it not only hinders your work, but it hinders the progress of the industry and defeats the purpose of your laws relating to weights and measures.

Recently the American Petroleum Institute divided its activities into the branches of production, refining, and marketing. Thus the institute is equipped to consider directly, and we hope efficiently, any problems in relation to marketing - of which the matter of establishing accurate weighing and measuring devices for petroleum products is one. It is the ambition of our division of marketing to 
work with you gentlemen that accurate measure of petroleum products may always be assured, and that the burdens placed upon you and your personnel may be lightened.

As secretary of the division of marketing of the American Petroleum Institute, I am in contact with the operating personnel of practically all of the oil companies who make up our membership. The division of marketing is accorded the position of official spokesman for the oil industry when matters pertaining to marketing problems are approached. As such spokesman, it becomes my duty to appear before you gentlemen in an official capacity and present the views of the industry on a matter of vital importance.

The demand for grease-measuring devices comes only for the serving of grease in the differential and transmission of automotive equipment. This was brought out by Mr. Smith in his paper. If we go back a number of years we will find that it was customary to set a barrel of grease on the curbstone in front of a garage, or at the service station, and serve the grease direct to the differential and transmission from such barrel through a hand-operated pump. Then there were developed hand-operated dispensing units for the 100 pound drum and the 400-pound barrel, and the hand-operated 25pound grease bucket, as a matter of convenience to operators. For, perhaps, the last 10 years these three hand-operated dispensing pumps on the 400-pound barrel, the 100-pound drum, and the 25 pound bucket, have been the standard equipment for the dispensing of grease into differential and transmission by the oil industry. The grease dispensed by such equipment was first sold by the pound, and later by the shot or stroke.

Two years ago when the code of specifications and tolerances for grease-measuring devices was first proposed, the oil industry welcomed any suggested changes that would enable them to render a better public service. A year ago a group of oil men, through the American Petroleum Institute, met with one of your committees and not only approred the fundamentals of the code, but made several valuable suggestions that were incorporated in the code as finally adopted. I think that fact indicates the attitude of the oil industry, which has traditionally been one of working with you people in a constructive manner. We are with you again to-day in the same spirit of cooperation.

I have talked with a great many members of the American Petroleum Institute recently. These conversations bear out the following facts:

1. That since the adoption of the proposed code at your last. conference a number of large oil companies hare made a diligent effort to secure grease-measuring equipment that complied with the code, and which would be favorably passed upon by the State sealers.

2. That as far back as January certain large oil companies announced through communications to the equipment manufacturers that it was their desire to anticipate the effective date of your code by then purchasing suitable equipment.

3. That as late as March of this year there were only two conlpanies that produced equipment which they claimed complied with the code. Only one of these manufacturers could supply the three 
necessary types of dispensing equipment; the other company could only supply one of the three types commonly used in the industry. Furthermore, both companies claim their equipment is protected by basic patents.

4. Within the last 60 days two other manufacturers have brought on the market units which they claim hare been submitted to some of the State sealers for approval. Within this short space of time the oil industry has not had the opportunity to put the equipment in use or test it to determine its accuracy, efficiency, and dependability.

5. At this very moment, so far as we are able to ascertain, no equipment manufacturer has a complete line of hand-operated equipment comprising the three necessary units, namely, the 400 pound barrel, the 100-pound drum, and the 25-pound bucket, that have been approved by any State east of the Rocky Mountains.

6 . It is our understanding that a number of equipment manufacturers have encountered mechanical and other difficulties in endeavoring to perfect the grease-measuring units to comply with the code as well as securing the approval of the State sealer's.

7. To put the code into effect this coming July 1 would be tantamount to forcing the oil companies to equip their stations and dealers with equipment that, considered in the most charitable light, is still in an experimental stage.

8. The oil industry has purchased some of the present units on the market, and is willing to purchase more of them when they are approved by sealers, and aid the equipment companies in their experimental work so that difficulties inherent in the manufacture of any radical new equipment may be overcome.

9. If the proposed code becomes effective July 1, it could not be complied with in a general way because no manufacturer is able to furnish a complete line, the supply of equipment would be grossly inadequate, and its production would be in the hands of so few companies as to exclude the oil companies from purchasing such equipment in a proper competitive market.

The oil industry welcomes any code, horrever drastic the requirements may be, so long as such a code is uniformly interpreted by the various sealers and promotes better public service.

The oil industry, through the American Petroleum Institute, has always worked along the lines of assuring the public of accurate measure, of aiding the State sealers and the Bureau of Standards in promoting better public service. WTe, therefore, only ask that a reasonable postponement of the effective date of the code of specifications and tolerances for grease-measuring devices be granted in order that the equipment manufacturers may develop, perfect, and secure the sealers' approval of hand-operated grease-dispensing units to comply with your code.

In view of the facts presented above, and the cooperation that at all times has been extended by the oil industry, we feel that it is only just and proper for this body to grant a reasonable extension of time as requested.

Gentlemen, I am very thankful for your very kind attention. Thank you. 
Mr. Ragland. Mr. Chairman, this is a matter of importance, and I have some questions which I would like Mr. Hadlick to answer. Mr. Hadlick, in 1928 this conference adopted tentative specifications. Was not the American Petroleum Institute familiar with those tentative specifications?

Mr. Haduick. I believe they were; yes.

Mr. Ragland. Yes, they were; and now you come here and tell us that the oil men "do not believe." Excuse me. We do not care what the oil men believe; we are working in the public interest. You set out in your magazine what you believe.

Mr. Haditck. Mr. Ragland, let me answer your question. We have nothing to hide. The publicity was sent out that the oil men were coming down to ask for an extension. If there is anything underhanded about that, I would like to know it. The publicity was prepared in my office. If we had said nothing about it and came down without advance notice before this body and asked for an extension of time, I think we might be taking an unfair advantage. We stand on the merits of my proposition.

Mr. Ragland. Did we not give you 13 months to gret ready for the enforcement of these specifications?

Mr. Hablick. We hare tried. We can not make the equipment. TVe are not in the equipment business.

Mr. RAGLaxD. What efforts have you made to buy the equipment?

Mr. Hablick. We have asked the equipment people for it.

Mr. Raglaxd. I can show you that my bureau has approred as many as 10 equipments.

Mr. HadicK. Are you speaking of the air-operated equipment?

Mr. Ragland. I am speaking of the specifications which require that all grease-measuring devices must be equipped with an indicator so that one can determine in pints the amount of grease delirered.

Mr. Haduick. $I$ think you are taking a rery antagonistic view of this. I am perfectly open and abore board.

Mr. Ragiand. All right. May I ask what companies have made efforts since the last conference to comply with these regulations, other than in Richmond? The companies are doing it in Richmond.

Mr. HadLick. Yes; I can tell that a great many companies are in the market for the equipment, but are they to buy it when it is altogether in the experimental stage? Richmond is not the only place in the United States, Mr. Ragland.

Mr. RAgLAND. I feel that it is. Certainly we have evidence of this-that Richmond has approved as satisfactory 12 or 14 different grease-measuring devices. What oil companies hare made appropriations for equipment? Have you made any appropriation for them?

Mr. HADLICK. I could not asik you to speak for the State of Virginia or the city of Richmond, except in your capacity. Now, I am not in the operating department of any company. I am in the American Petroleum Institute. Howerer, I will be glad to call upon representatives of the various companies who are here, and they will be glad to answer your question.

Mr. Ragland. How many companies have continued to put out oldstyle equipment, regardless of our specifications? 
Mr. Hadicr. I do not know. I will say that there is no desire on the part of the oil companies to increase the amount of equipment of the old style at this time. I know companies that have discontinued purchasing, who would rather put in new equipment.

Mr. RagLaNd. You know companies are now holding up contracts to see what we will do to-day.

Mr. Hadlick. You do not blame them.

Mr. Raglaxd. Do vou know that since 1928, through my good friend, Mr. Fuller, the grease proposition has been enforced in California?

Mr. HadLICK. I believe that is right.

Mr. Raglaxd. You said there were two or three units that you knew of. Are there not more than three?

Mr. HADLICK. I do not know that there are more than three.

Mr. Raglaxd. Iou ought to know. Look at them [handing paper]; there they are.

Mr. Hadirck. You tell me. The city of Richmond is but one city in the United States. What company, for example, do you know of that can supply the dealers with approved units to serve from 25pound, 100-pound, and 400-pound containers? What company is putting out a full line that has had the approval of all of the States, or if it has had the approral of some of the States, what States are ther?

Mr. RaGLaNd. I will not name companies. I am not advertising them.

Is there any oil company that you know of that could not get approved grease-measuring equipment because the manufacturers could not guarantee delivery?

Mr. HADLICK. I will refer you to one of the purchasing agents. Mr. Malone, can you answer that question? I am not trying to pass the buck, but trying to get some information for you.

Mr. Malove. I can answer your question by saying there is not a company that could supply the industry to-day with sufficient equipment that would enable it to comply with the code as of July 1, 1930 .

Mr. Ragland. Have you tried to buy this equipment?

Mr. Malone. Yes; we have tried to buy. Will you please name to me any concern that has these three pumps, approved by State sealers east of the Rocky Mountains?

Mr. Ragland. I am not going to advertise.

Mr. Malone. We are very much interested.

Mr. Ragland. Do you know of any oil companies that wanted to make contracts for needed grease equipment during the past three months that the manufacturers refused to accept on account of not being able to handle the business?

Mr. Maloxe. Yes; our company announced as far back as January of this year that we were willing then to invest our money in equipment that would pass the approval of State sealers in the district where we operate. We have yet to find any company that can furnish the three units that we are talking about.

Mr. Ragland. Why do the companies figure that they will require a large number of pieces of apparatus when they are permitted to use equipment already installed in the field? 
Mr. Maloxe. You know that when any new piece of equipment comes on the market everybody wants it. When the new equipment comes on the market, approred by all State sealers, ererybody will want it, and that automatically obsoletes all other equipment.

Mr. Ragland. I think I have made it perfectly clear that this is a smoke screen.

Mr. HADLICK. If the Chair will permit. Mr. Ragland has brought up some questions and innuendos and inferences of unfairness and I do not like it.

Mr. Malone has a list which comprises all of the manufacturers of grease-measuring equipment known to Mr. Holbrook. I added some companies that I had and Mr. Malone carried on a long correspondence with those companies. I think Mr. Holbrook has the original correspondence. I said I thought only two or three were ready to furnish equipment complying with specifications. Mr. Ragland talks as though there are a dozen. I would like Mr. Malone to read the list.

(SECRETARY'S NOTE.-In the discussion which follows, the names of a number of manufacturers of grease-measuring equipment were mentioned. Since it is not considered adrisable to include these names in the record ther hare been deleted.)

Mr. Malone. The firm first on the list is a general contractor and apparently hare bought patents held by another company. They have no literature describing the equipment.

Mr. Griffith. What is the date of that correspondence?

Mr. Maloxe. This correspondence starts March 14 and ends April 23, 1930 .

Mr. RAgLAxd. That is a rather late date to start.

Mr. Maloxe. No; I wrote Mr. Holbrook on March 4 and told him that after diligent effort we found nobody who could supply us with the equipment that would meet the rarious State requirements. Mr. Holbrook countered, telling me that he was quite surprised, that he understood through trade papers that some concerns were prepared to furnish proper equipment. He mentioned that he had a list comprising the names of some 32 companies in all who manufactured grease equipment. I wrote back and told him I would appreciate his sending me the names of the 32 and that I would be glad to canrass each one of them and see what they had to offer. That was done, and Mr. Holbrook has my original file. Now. this, that I am reading. is a résumé of what we found at that time.

The next company on the list has apparently discontinued the manufacture of grease guns. The equipment manufactured by the next company is an air container, using air pressure with meter. The next company does not manufacture measuring equipment; they apparently are not familiar with the specifications nor interested in the manufacture of equipment in compliance.

The next company does not manufacture meter equipment and apparently does not intend to be "bothered with new requirements:" as they put it in their letter.

The only equipment the next company has to offer is a portable air-operated unit for lubricating pin fittings. and this is not the type of equipment we have under discussion. The next has a pressure grease tank which could not be used in places where a grease pump 
and so-called 100-pound units have been used in the past without a tremendous increase in investment. The next is not in position to furnish equipment as they were under direct contract for their entire output. The equipment of the next company is also air operated. The next company is manufacturing only a high-pressure grease gun, and has not any grease-measuring devices ready for release. The equipment of the next company is also air operated. The next company principally manufactures garage equipment. Their grease bucket has no measuring device.

The next company apparently has no equipment in production but seems to be the only concern that is interested in the manufacture of grease-measuring devices that could be placed on each of the present grease containers. The next two companies do not manufacture grease-measuring devices. The next company was the only concern that was marketing equipment similar to equipment used to-day, with the addition of an indicating device, but they only had approval on the west coast. The next are strictly jobbers handling lubricating equipment manufactured by others. The next was the only concern that could produce the three units that we speak of, and they had, at that time, the approval of only five State sealers and of the city of Richmond.

Mr. Ragland. That alone ought to put it over.

Mr. Malone. The next company does not manufacture greasemeasuring devices. The next unit is air operated and has not been approved by all the States. The next company contemplates building differential grease pumps, but had nothing to offer at that time. They have since come out-on May 14 -with an advertisement that they have a piece of equipment; they go on to say it is not in production and it will pay to wait.

The next letter best illustrates the trouble that the manufacturers have in producing equipment. At the present time they have nothing to offer. The next company replied in answer to a letter addressed to another company. They did not have anything to offer, but are jobbing the unit of another manufacturer. The next does not manufacture any grease-dispensing units to meet the specifications of the National Conference on Weights and Measures.

There were four more concerns that we wrote on four different occasions, but we have not had a word from any one of them.

Now, if you will permit me, to bring this down to date, since our efforts to get equipment there has been quite an effort-in the last 60 days-to bring something out in a hurry. That has been done by the outfit that you have approved at Richmond.

Mr. RAgLAND. I will prove there are more than that.

Mr. Malone. I am perfectly willing to be shown, and you will have your time later.

These people, as late as May 21, turned over to an eastern company the right to manufacture their apparatus, but to this minute they have not secured approval, with the exception of the city of Richmond, east of the Rockies.

There is one other concern that has one unit of the three that we are talking about, that fits into a 100 -pound drum that has received the approval of five States and the city of Richmond. There is another concern, which I mentioned, that can produce the three, but as yet has only produced two of the three, and has submitted them 
to not more than three States. They have secured, to my knowledge, the approval of the bucket and the 100-pound drum. I would be very glad to know of any other manufacturer that has equipment of the type we are talking about.

Mr. Ragland. You mentioned the company. Did you try to place a contract with that company. for.

Mr. Malone. That is not the type of equipment we are looking

Mr. Ragland. And the kind of equipment we want is the kind of. equipment that the specifications demand; that is, a grease device equipped with auxiliary equipment to determine in pints the amount of grease dispensed. Have you tried to buy the _- equipment?

Mr. Malone. We have, for you, down in Richmond. Where else has it been approved?

Mr. Ragland. Have you tried the - ?

Mr. Malone. That is a separate meter.

Mr. Ragland. Have you tried the - company?

Mr. Malove. Yes; I have read what they said.

Mr. Ragland. 'There [indicating] is the approval of that gun.

Mr. Malone. Those are all your approvals. As we said before, we do not sell only in Richmond, but all over the country.

Mr. Ragland. When you try to throw a smoke barrier

Mr. Sarbolt (interposing). Pardon me. You imply an unfairness on the part of the Petroleum Institute which I think is unfair, and I take an exception to it. You can not back up your charge of unfairness on the part of the Petroleum Institute.

Mr. RAGLAND. I can prove any statement you want to mention.

Doctor Burgess, I do not care to take up any time in further discussion, and I will make a motion now that the conference on weights and measures in session here to-day refuses to put up with this postponement on one cause or another; that we will not have any postponement but that the program, as adopted last year, effective July 1, 1930, shall go into effect.

The Chairurax. I am afraid, Mr. Ragland, your motion is not in order.

Mr. Baker. Mr. Chairman, I would like to say in defense of Mr. Hadlick and Mr. Malone, that it has been very difficult to know how the specifications would be interpreted and what will satisfy the sealers of weights and measures-what sort of device it will take to meet the requirements. I think if it is definitely understood what sort of derice is required, that will clear up the situation. I think it is lack of this knowledge that has prevented the manufacturers from going ahead.

Mr. Maroner. Mr. Chairman, we are very fortunate in having with us to-day an engineer of a large company, whose letters are on file here. I believe he can give a synopsis of what has been done.

The Chairitax. I would be very glad to hear from him.

Mr. Carriger. Mr. Chairman and gentlemen of the conference, in case you do not understand my position, I feel that in fairness I should state that I represent a manufacturing company. As a representative of that company, I am compelled to support Mr. Malone in the statements he has made. Up to the present time we have not been able to develop the devices required by the industry to meet the 
specifications of the code. This is not because we have not triedwe have spent thousands of dollars-but because of lack of time we have been unable to get around to the various sealers and obtain a general universal interpretation of what the code demanded. We made devices and took them to one sealer and, perhaps, would get his tentative approval. In the next State approval might be refused. Acting on the suggestion of the second man we would add something to the device and receive his approval. However, when we went to the third man he might disapprove the device.

The people in Washington have been very fair, and I think they will bear me out when $I$ say that it is possible that an amendment will be added to these specifications, and I submit that the specifications were not clear or they would not have to submit an amendment at this time.

There is no intention on our part, as manufacturers, to delay the manufacture of grease-dispensing devices that will meet the requirements of the oil companies and come within the code, because manufacturing equipment is our business. When we can make them we can sell them. When we sell them sometimes we make some money. That is how we exist, and I feel that I must support Mr. Malone with all the force at my command. Our failure to get equipment on the market has not been due to lack of diligence, but to our inability to get a clear understanding of what was wanted. We want to make devices complying with a broad interpretation of the code.

We are here seeking knowledge. We came down to get an idea of what you want. We are going back to our plant and, gentlemen, we are going to develop grease outfits just as quickly as we can and just as well as we can; we want them to be as perfect as we can make them and within the rulings of the code.

Mr. Griffith. Mr. Chairman, I would like to ask the gentleman if the regulations and specifications that were promulgated here two years ago did not make it clear to him what was desired. Did we not tell you what we want?

Mr. Carriger. The specifications were not clear to us, and the opinions of the sealers bear me out.

Mr. Ragland. Did you fail to understand what we wanted or was it a doubt as to what the Petroleum Institute wanted?

Mr. Carriger. The latter phase was not given consicieration. Our sole endeavor was to get something that the sealers wanted.

Mr. GrIFFItr. Those specifications were promulgated after due deliberation; a year elapsed and they were reiterated with a tentative specification added. Now I would like to ask Mr. Smith a question. Mr. Smith, in your paper you mentioned some 10 different types. I would like to ask if any of those complied with the specifications.

Mr. Sмrтн. As I stated in my paper, no effort was made in my analysis to determine whether or not the units discussed were in compliance with the code of the conference. The idea of my paper was to describe what is on the market and how the various units operate.

Mr. GRIFFrif. In your unofficial observation did you make note as to which complied with specifications? 
Mr. Smith. I would not be prepared to say from my unofficial observation whether any of them did or did not.

Mr. Grifritr. I think there are some other grease-measuring device manufacturers represented here and it might be well to hear from some of them who have successfully met the specifications. While I have heard the speakers through, pro and con, I want to say that in Baltimore, Md., there are five different machines for dispensing grease which, according to my interpretation, comply with the specifications, and that will be approved as long as they measure accurately.

Mr. Ragland. I would like to ask Mr. Carriger whether his company did not instruct their salesmen not to try to sell grease-measuring devices because there is no profit in it.

Mr. CARriger. No; that is not true.

Mr. Ragland. Doctor Burgess, I want to make this statement and then I am through.

I attended this conference last year. I went before the committee. We had a very pleasant talk-they are a bunch of very sensible menand they said to me-

Ragland, you are premature. We are going to put these specifications out as they are, and we are going to put a footnote at the end of the code, to read as follows :

"General Note.-Device to indicate exhaustion of supply.-The conference goes on record to the effect that it is its opinion that such a device as is mentioned in the following paragraph is a very desirable one, but considers that the time is not yet ripe to recommend its adoption. The conference suggests, howerer, that at some future time steps may be taken to incorporate the following paragraph in the code of specifications.

"All grease-measuring derices shall be provided with a device which will make the unit inoperable when the supply of grease or transmission oil has reached a point where the accuracy of delivery would be affected, or shall be so constructed as to warn the purchaser and the operator in a conspicuous and distinct manner that the level of the supply is so low as to endanger the accuracy of the measurement."

We have put you on notice. The Bureau of Standards has had this printed and we have done everything we could. I believe you have judgment and confidence in my judgment. I believe all the time that is necessary has been allowed, and I am going to close by telling you that I know there will be no postponement.

Mr. Fuller. I would like to say to the delegates that in California, where we have already put these specifications into effect, there are eight or nine devices complying fully with these specifications, and I can assure you that we put them to as thorough a test as would be required anywhere.

Mr. Spaetr. Mr. Chairman and gentlemen, I have no objection to the new specifications from the manufacturer's standpoint. I think it should be required to sell commodities by weights and measures absolutely, and if the requirement is that you must do it, that is all there is to it.

Now you gentlemen know that when you have a 100-pound drum, and it is 33 or 25 per cent empty, and a.man comes in for 10 pints or 10 pounds, nine times out of ten the grease does not flow, and unless the operator wants to be honest he will give you about 7 pounds instead of 10 pounds due to sucking up air. I have tried it from A to $\mathrm{Z}$. Now, here is a thing I wrote up yesterday in a hurry: 
What are the problems in dispensing differential and transmission grease from a customer's and operator's standpoint, as compared with oil? In the first place, a customer specifies and receives a predetermined quantity of oil and has positive means to check the operator, which is impossible when it comes to purchasing transmission grease. He simply states, "Fill up my transmission or" differential," without knowing the amount required or received. Now what is the operator up against? When dispensing oil, he has positive means to check up his quantity in storage, in the form of a gage stick. $\mathrm{He}$ uses visible means, such as a measure or bottle, and simply counts the number of quarts or pints he transfers to the crank case-without a counter, by the way.

What about grease? I have prepared a few questions and answers in this relation which I will read. "Can a customer specify the quantity of grease to be purchased?" The answer is "No." "Has the customer a positive means to check up the operator to determine the quantity received and paid for?" The answer is "No." "Has the operator positive means to check his supply?" The answer is "No." "Why not?" The answer is, "The container may be half full along sides and at a minimum at intake or there may be air pockets in the grease."

"Is material dispensed by visible means?" Answer-"No." "Has operator positive means to show what transpires when turning crank handle back and forth?" Answer-"No." "Why not?" "It is practically impossible to check supply, and delivery is made by invisible means and from invisible supply." "Will a counter or meter attached to crank-type pump measure correctly?" Answer-"No." "Why not?" Answer-"For the reason that they register pump strokes only." "Is a counter for individual sales now used?" Answer-"Such is proposed." "Will it have any bearing on correct measure?" Answer-"No."

In conclusion, since it is the accepted practice to purchase all commodities by either weights or measures, and since the transactions are supervised by State departments of weights and measures, the first consideration should be to devise a device that will eliminate the unknown quantities outlined above. The addition of various accessories to present-day equipment, such as meter and counter, will not solve problems at hand, and simply means a bill of expense to the operator without accomplishing the object.

Now, what is the answer? The answer is to provide visible means to show the customer and operator that grease is dispensed 100 per cent with definite visible means to show that supply is not exhausted. 'The answer is the last paragraph in last year's specifications and that is the only answer to this problem that will be perfectly fair to both the customer and the operator.

Mr. BARRETT. Mr. Chairman and gentlemen, what I have to say is this: In answer to the comments you have just heard, it is granted that the devices which are now available do not in every case indicate when the supply reaches exhaustion, and that is a condition that has not yet been perfected. Still, are we to fail to go halfway, or rather fail to go three-fourths of the way, because we can not go all 
the way? Iet us adopt what we can do and work for what we can hope for in the future.

Another point is this: The statement has been made by various companies that none of the equipment manufacturers to-day manufacture all three of the kinds of equipment needed. I can not speak positively as to this, but I do not believe that is of particular importance. If we can not get all three from one company we can get one kind of equipment from one company and from another we can get another kind. The fact is, I do not know of any of the larger companies who get all of their equipment exclusirely from one pump manufacturer; so they only suppose that they must purchase all of their 25-pound, 100-pound, and 400-pound equipment from one manufacturer.

In connection with the availability of equipment that meets the specifications, I realize that the oil companies have various problems, not the least of which is the securing of equipment at modest prices. Sometimes that is a very predominating problem, under marketing conditions; but I do know that equipment is manufactured which meets the specifications laid down by this conference last year. When these regulations were proposed last year that type of equipment was available in large quantities. It is now being sold in lots of thousands of units, and it can be sold in many times the quantity that it is now being sold. I do know that there are manufacturers-iny own company included-who make derices in accordance with the specifications of every State which requires such approval, and that, I think, is the answer to the discussion that has been brought up this afternoon. Equipment is available that meets the specifications. Now, whether it meets the requirements of price is another question, although here again, the price, I believe, is very modest and offers a not insurmountable obstacle.

Mr. Hadlick. Do you put out equipment to comply with specifications?

Mr. BarRetT. We manufacture meters only.

Mr. HadLICK. Has your meter been approred in erery State?

Mr. BarretT. Yes; in every State in which approval is now required.

Mr. Haduck. How many States?

Mr. Barretr. To the best of my knowledge, California, Massachusetts, Virginia, Vermont, and cther States that I know require specific approval.

Mr. Hadick. What companies have you sold them to?

Mr. Barretr. Principally to three, but there are a half dozen others who are purchasing in greater or less quantities.

The code specifically mentions that while it is desirable to indicate exhaustion of supply this is not insisted upon at present. Therefore, our meter complies with the code.

May I mention this point, which I think is essential. The elimination of air presents quite a problem. Any meter which is to record must be a positive displacement meter. It is very natural, therefore, that it will register air the same as grease. Therefore, the solution of the problem is to avoid the registration of air by keeping 
all air out of the meter line and that is the function of the tank or the bucket in which the meter is set. That can be done by means that are now available, as many of you will agree.

Mr. Ragland. Do you not think the oil companies in the United States, if they had wanted to comply with the specifications, could have gotten all the equipment needed and a little more besides?

Mr. Barrett. You have made a point that I had hoped would be brought up. We have found a lack of interest on the part of the grease customers.

Mr. Trxkey. I would like to state that this code of specifications and tolerances for grease-measuring derices was adopted tentatively by the conference in 1928 and, after considerable discussion, it was agreed that the code should not become effective before July 1, 1930. Now, I would like to explain that in Ohio when we decided on the date of July 1, 1930, to adopt the code permanently, that did not means that on July 2 everybody would have to have a measuring device to correspond with the code. We did not expect that. But we expected grease-measuring devices, in compliance with the code, would be put into service and that, perhaps, during the next year there would be many more. Now is not that fair?

Mr. Haduick. Yes; but automatically every dealer will want them.

Mr. Trxkex. And we will approve them as fast as we can.

The Chambrax. The author of the paper asked for a postponement of the date for the putting into effect of the code of specifications and tolerances for grease-measuring devices. Is there any member of the conference that would care to make a motion on that point?

(No motion was made.)

REPORT OF COMMITTEE ON SPECIFICATIONS AND TOLERANCES ON MIODIFICATION OF SPECIFICATIONS FOR GREASE-MIEASURING DEVICES, PRESENTED BY F. S. HOLEROOK, CHAIRMAN

Your Committee on Specifications and Tolerances has reviewed the code on grease-measuring devices and has only one amendment to propose, namely, an amendment to specification No. 3 in relation to "indication of delivery."

The first portion of this specification now reads as follows:

3. Ixdication of Deliverr.-All grease-measuring derices shall be so designed and constructed that the initial zero condition and the amount delivered in terms of liquid measure shall be clearly and definitely indicated by automatic means * * *

It is now recommended that the specification be amended to read as follows:

3. ITdicatrox of Detrvery.-All grease-measuring derices shall be so designed and constructed that the initial zero condition and the total amount delivered to an indiridual purchaser shall be clearly and definitely indicated in terms of liquid measure * by automatic means: Provided, however, That the capacity of the registering or tallying device demanded by the above shall not be required to be more than 5 pints: And provided further, That a device in use at the time these specifications take effect shall not be required to comply with the above requirement for automatic indication of the amount delivered when the device delivers, within the tolerances hereinafter provided, a unit quantity of a pint, a multiple of the pint, or a binary submultiple of the pint per stroke or per cycle of its operating elements, and when, in addition, the device is conspicuously or permanently marker to indicate the value of this unit quantits. 
* NotE-Devices which at the time of adoption of these regulations in any jurisdiction are marked to deliver in pounds rather than in pints and which in other respects conform to the retroactive sections of this code or are susceptible of being made so to conform, should not be condemned and confiscated on this ground alone, but the word "pound" should be obliterated wherever it occurs and the word "pint" substituted therefor. In this case the device should be readjusted if necessary.

NoTE.-The requirement for a tallying device, contained in the foregoing specification, shall not be put into force and effect prior to July 1, 1931.

(Signed) F. S. HoLsRook, Chairman.

I. L. MILLER,

A. W. SchWARTZ,

Charles M. Fuller,

Committee on Specifications and Tolerances.

Mr. Ragland. I move that the report of the committee be adopted. (The motion was seconded, the question was taken, and the motion was agreed to.)

(At this point, at 4.57 o'clock p. m., the conference adjourned to meet at 10 o'clock a. m., Wednesday, June 4, 1930.) 


\section{THIRD SESSION (MORNING OF WEDNESDAY, JUNE $4,1930)$}

The conference reassembled at 10.06 o'clock a. m., at the Burean of Standards, Dr. George K. Burgess, president, in the chair.

\section{REPORT OF COMIMITTEE ON SPECIFICATIONS AND TOLERANCES ON SPECIFICATIONS AND TOLERANCES FOR ODOMETERS, PRE- SENTED BY F. S. HOLBROOK, CHAIRIMAN}

Your committee on specifications and tolerances was requested last year to prepare a code of specifications and tolerances for odometers, which are machines for measuring the distance traveled by vehicles, especially automobiles, to which they are attached. These machines are of several general types. One type of odometer, called the hubodometer, is attached directly to the hub of the vehicle; another odometer, which may be mounted on the instrument board or elsewhere about the vehicle, is driven by a cable attached to the transmission or to a front wheel; a third is the mileage-recording portion of a "speedometer" assembly of the usual type.

Of course, as weights and measures officials, you will be interested in only a few of the odometers in use. Obviously you will not be concerned with odometers on private cars. However, odometers are frequently used commercially, and they may be put to uses which may be designated as quasi-commercial; for instance, under the following conditions: (1) An odometer on a "drive-yourselif" car, when the charge made for the hire of the vehicle is based, wholly or partly, on the number of miles traveled by the vehicle and registered by the odometer; (2) an odometer which may be used, in some jurisdictions, in regular taxicab service; (3) an odometer used for the purpose of determining the amount to be paid for liability insurance, when the liability insurance is not on a basis of a flat rate per car but is on a basis of miles traveled; (4) an odometer used for the purpose of the assessment of taxes when a tax against a public vehicle for the use of city or State roads is on a mileage basis. It is such uses as the above which may bring the instrument within the jurisdiction of the weights and measures official and which make advisable the adoption of a code of specifications and tolerances.

Copies of the recommendations of your committee have already been placed in your hands.

In accordance with the usual custom, words shown in italics are intended to be nonretroactive. As in the case of all new codes, your committee recommends this code for tentative adoption only.

Respectfully submitted.

(Signed)

F. S. HoLвrook, Chairman,

A. W. SchWARTZ,

Charles M. Fuller,

I. L. Miller,

Committee on Specifications and Tolerances. 
Mr. Holbrook. The introductory material, the definition, and specification No. 1 read as follows:

Notes.-The following specifications and tolerances shall apply to odometers in those cases in which odometers are used or to be used commercially - that is, to determine charges for hire of a vehicle-and such use shall be permitted only when these specifications and tolerances are complied with. Whenever odometer readings form the basis for the payment of fees or taxes to or for the preparation of reports for governmental agencies, for the determination of insurance premiums, or in other such cases, and weights and measures officials undertake to inspect and test such odometers, what follows is recommended as the basis for such examinations; the requirements should be applied in so far as they are applicable and not modified by the conditions surrounding the special use.

It is strongly urged that compliance with the tolerances be determined by the performance of the complete assembly installed on the vehicle with which it is to be used, in a road test over a measured course. During such test the vehicle shall carry an average load and the tires shall be inflated to normal pressure recommended by the manufacturer of the tires.

It is recognized that physical limitations, such as very heavy traffic conditions in the vicinity of the place where the tests of odometers must be made, may in certain instances preclude the possibility of the road test recommended. Necessarily in such cases some other method of test must be resorted to. The only other method of test which is at all adequate is that known as the "wheel test," which is a test of the entire odometer assembly when mounted upon a vehicle, the mechanism being actuated by the mechanical revolution of the vehicle wheel while the car remains at rest. The corresponding vehicle travel can be computed when the rolling circumference of the tire on the wheel of the vehicle which actuates the odometer, under arerage load and with normal tire inflation, is accurately known, and this computed travel can be compared with the registration of the device. Specially constructed apparatus will be necessary if the test is to be made in this way.

The "bench test" is believed to be inadequate for odometer assemblies and is not recommended.

After approval of the complete assembly, suitable seals shall be applied so that no part of the odometer mechanism or of the connections leading thereto may be removed, or modified in such a way as to affect the accuracy of registration, without destroying or mutilating the seal or seals.

Whenever an odometer has been damaged, whenever repairs which might in any way affect the accuracy of its registration have been made, or whenever any of the official seals have been destroyed or mutilated, such odometer shall not thereafter be used commercially until inspected and, if deemed necessary, tested by the weights and measures official.

Definition.-An odometer is a mechanism or machine designed to be attached permanently to a vehicie and adapted automatically to register the distance traversed by the vehicle. For the purpose of these specifications and tolerances, this definition shall be construed to include hubodometers, cable-driven odometers, and the mileage-recording, or odometer", portions of the so-called "speedometer" assemblies for automobiles.

Specifications.-1. Character of IINDication.-Odometers shall be so designed and constructed that they will register in terms of miles and tenth-miles.

The Chamman. Our usual procedure is to act on the several items as these are read. If that is your pleasure, we will adopt that procedure.

Mr. Sweener. Mr. Chairman, I move that the portion which has been read be adopted.

(The motion was seconded, the question was taken, and the motion was agreed to.)

Mr. Holbrook (reading):

2. MOVEMENT OF INDTCATORs.-All odometers shall be so designed and constructed that when installed on a vehicle the registration of the odometer shall be susceptible of increase only by the rotation of the vehicle wheel or wheels. 
The tenth-mile indicator may advance contiuuously or intermittently; other indicators shall advance intermittentiy. In all eases in which indicators advance intermittently, movement shall be communicated to the indicator drum or dial only during that period in which the adrance of the mechanism corresponding to not more than the one-tenth mile immediately preceding the next higher indication, is taking place. An odometer may be provided with means for reducing the registration to zero.

Mr. Foster. Mr. President, it seems to me it might save time to dispense with adoption section by section. Comments can be made on each section as read and then at the conclusion a vote can be taken on the whole report.

The Crampian. If there is no objection on the part of the conference, it is agreed that we will vote on the whole code when the reading is concluded.

Mr. Stevers. Mr. Chairman, there is one comment I would like to make at this time. There is nothing in there which prevents an odometer being run backward and the registration thereby decreased to reduce taxes or insurance premiums. It seems desirable to specify that the registration of the odometer should not be susceptible of being decreased by running it backward. In other words, there should be some sort of device included so that if the wheels are turned backward this will not decrease the record.

Mr. Hor BrooK. In relation to that, the committee had in mind that when these odometers are used for fixing insurance premiums or for taxation purposes this code is only to be applied in so far as it is applicable, and the special use shall govern the details of the construction. For instance, this specification allows the registration of an odometer to be reduced to zero, but such a provision should certainly not apply to an odometer to be used for insurance or taxcollection purposes. However, in the case of odometers used on "drive-yourself" cars, for instance, the committee sees no reason why, if such a construction is desired, the odometer might not be so constructed as to allow it to be turned back to zero at the beginning of every hiring: Obviously, in that event the companies operating these cars would select an instrument so constructed that a customer could not reduce the record before returning the machine to the owner; a special key might be required, for instance.

Such special uses have been provided for in the introductory notes by the language:

Whenever odometer readings form the basis for the payment of fees or taxes to or for the preparation of reports for governmental agencies, for the determination of insurance premiums, or in other such cases, and weights and. measures officials undertake to inspect and test such odometer's, what follows is recommended as the basis for such examinations; the requirements should be applied in so far as they are applicable and not modified by the conditions surrounding the special use.

\section{Mr. HoLвroor (reading):}

3. Ritadabitity of INDications.-Mileage figures and the apertures through which they are viewed shall be of such size, design, and location that the indications of the odometer may be easily and accurately read. The figures and their backgrounds shall be of sharply contrasting colors; the color of all fingers except those indicating tenth-miles shall be uniform, and the color of the tenth-mile figures shall be different from the color of the other figures. Except during the period of advance of an indicator to the nezt higher indication, only one figure on each drum or dial shall be exposed to view. Any protective covering intended to be transparent shall be in such condition that it can be made transparent by ordinary cleaning of its exposed surface. 
4. Visibiutty of Registration.-Whenever an odometer is utilized upon : vehicle in lieu of and for the purposes for which a taximeter is commonly employed in regular taxicab service, the odometer shall be so positioned oi! the rehicle that the registration of the device is in full view from the interior of the rehicle; in all other cases the odometer shall be so positioned that it is readily accessible for the reading of its registration.

5. Prorisior for SeAlirg. - Adequate prorision shall be made for sealing in place all complete odometer assemblies-that is, installations upon rehicles of odometers and the rarious gears and other parts required for service operation-in such a manner that no adjustments, replacements of or to any parts of such assemblies, or alterations, which might affect in any way the accuracy of the odometer registration, can be made without destrojing or mutilating the seal or seals.

The seal or seals required by the provisions of this specification shall be so applied that they are visible; that is, it shall not be necessary to disassemble or remove any part of the iehicle or odometer to determine whether such seals are intact.

6. Perdraxexce.-Odometers shall be of such design, construction, and materials that they may reasonably be expected to uithstand ordinary usage uthout impaiment of their accuracy or the correct functioning of their operating and indicating warts. This specification shall be construed to require that in the case of ratchets and paicls and similar combinations, wherever the accuracy or consistency of the indications of the odometer would be affected by the uearing away or the deformation of one or both of the cooperating parts, the ratchets and pauts shall be fabricated of such material and shall be hardened to such a degree and extcht that the wear or deformation resulting from use will be reduced to a minimum.

7. Fratditext Coxstrectior.-All odometers and all mechanisms and derices designed to be attached thereto and used in connection therewith shall be of such design and construction and shall be so installed for use that they do not facilitate the perpetration of fraud.

Tolerances. - The tolerances to be allowed on the registration of odometers with respect to distance actually traversed or computed shall be as follows:

Tolerance in deficiency (orerregistration): None, except when the rehicle tires are seriously worn in which case 1 per cent of the interval under test shall be allorred.

Tolerance in excess (underregistration): Four per cent of the interral under test.

The Chamuax. Gentlemen, you have heard this report. What is your pleasure?

Mr. Foster. Mr. Chairman, I move that the report be adopted tentatively as recommended by the committee.

(The motion was seconded, the question was taken, and the motion was agreed to.)

The CHarrirax. Gentlemen, we have the great pleasure to-day of listening to a man in the House of Representatives who is charged with the scrutinizing of proposed legislation relating to coinage, weights, and measures introduced in the House of Representatires.

I have the honor of introducing the Hon. Randolph Perkins, chairman, Committee on Coinage, Weights, and Measures, House of Representatives.

\section{ADDRESS BY THE CHAIRMAN OF THE COMMITTEE ON COINAGE, WEIGHTS, AND IMEASURES, HOUSE OF REPRESENTATIVES, HON. RANDOLPH PERKINS}

Mr. Director and gentlemen of the convention, when I listened so attentirely to the paper on specifications and tolerances for odometers, I thought perhaps the next speaker might say something on specifications and tolerances for Congressmen. because it is a very weighty matter when the chairman of the Committee on Coinage, Weights, and Measures meets with the National Conference on 
Weights and Measures; but in view of the fact that this session of Congress is measurably reaching its conclusion, a spirit of levity rather than of weight prevails this morning with the speaker. I know the work that you gentlemen are doing to some extent, and $\mathrm{I}$ offer my hearty cooperation so far as I can give it. But it seems that this serious meeting and these serious papers might well be interrupted for a moment with a little less serious thought, perhaps intermingled with a little bit of philosophy.

If we were to have the tolerances suggested for Congressmen, perhaps we upon the Hill who are doing what we can with the little light we have to help in the standardization and the passage of laws in reference to weights and measures might be treated with a little tolerance when we consider matters not only of the head, but also of the heart. How a Congressman is viewed by the people throughout the country, generally, it is very difficult for those of us on the Hill to appreciate. Usually the American people we meet with are sufficiently polite to say reasonably good things of us, but that does not necessarily mean that we are taken as seriously as we are inclined to take ourselves.

$$
\text { * * * * * * * * * * * }
$$

Now I feel I am getting serious, and I do not intend to do that. The world at large seems to be distressed about the United States standardizing everything too much. We are worried least of all by standarization. Why, we have a doctor on the "hill" who goes around and measures the heads of Congressmen-that is, on the outside-trying to standardize Congressmen. I do not think we need worry about that type of standardization. As I see it, what we are trying to accomplish, what you are trying to accomplish, is the standardization of ponderable things-things that can be weighed and measured-and the standardization that we have in this country has resulted in the development of this tremendous prosperity, the greatest the country has ever had. But I do not think we will standardize a man's heart or head. We may ride in the same kind of a car. The car may be standardized, but what is going on inside of the man is far from being standardized. Moreover, what we want to escape is mental or emotional standardization.

$$
\text { * * * * * * * * * * }
$$

In the last few years the whole world has taken on new aspects, I believe. A good part of our law came down from customary law, but now, of course, it is practically all enacted law and court decisions; but I say, gentlemen, as I read your papers and as I hear discussions before the committees of Congress, that alongside of enacted law there is growing up a great body of customary business practice in this country, and I dare say the very report which was just read is along the line of that business practice. That is a splendid thing, because men in business are beginning: to learn that the real way to conduct business is to conduct it according to certain ethical practices. We, in this day, are beginning to realize the truth of the old saying that honesty is the best policy, and so there is growing up this great body of business practice on a strict ethical basis-men get together who are interested in the same subject, discuss their problems, read paper's, and pass resolutions designed for the conduct of business on a high ethical plane 
common to all; this, of course, is along the lines of standardization and has resulted in the elevation of business to a high level.

Now, the work that we are doing in Congress is, of course, just being done by human beings like yourselves. We realize that it is the most difficult thing in the world to pass remedial legislation. It is not difficult to see the wrong. It is not difficult to see where people are injured by existing conditions. The great difficulty is to find the proper remedy.

I think it was Mr. Huxley who said, "Give a man a thin sheet of metal with a bend in it; give him a hammer and tell him to straighten it out. Before he has it straightened out he will have a hundred dents in it."

The work that you gentlemen do is exceedingly helpful. In fact, it is the real work. We only attempt to crystallize into statutory form the thought and the conclusions of the bodies of men throughout the country who are giving various subjects their earnest consideration. Now, we do not move as fast as some would like, but I have often found in my own case that when I travel too fast I often have to retrace my steps somewhat.

I just want to say this concluding word, that it is a real pleasure to come and meet with you here. It is a splendid thing to see men who take their time, who use their energies and their brains, to bring about standardization of weights and measures-who deal with this broarl subject. Why, you know, friends, the world does not realize what a large subject this is. Practically all of science is based on weights and measures, which means that practically all material advancement in the world is based on weights and measures. Sometimes. when I get a little philosophical, I begin to wonder if nature ever intended to have us civilized-I sometimes doubt it. Mankind has had such a hard struggle to attain to his present position. The work you are doing is a helpful illustration of the great efiort of the scientist in the advancement of the human race.

I must say, gentlemen, that I honor your efforts, your energy, in coming here and dealing with these subjects which, to the outside world, are dry and, perhaps, uninteresting, but which, in the final analysis, enable the bulk of the people to advance, and enable your legislators to say what is necessary to assist the country in this great work of standardization of measures and of weights.

I want to say it is a real pleasure to have been with you, and I trust when another year rolls around that we will all be able to gather here and renew our friendship.

Mr. Sweener. Mr. President, I ask that a rising vote of thanks be given to the honorable gentleman for his address here this morning.

(The motion was seconded, the question was taken by a rising vote, and the motion was agreed to.)

\section{SOME OBSERVATIONS ON WEIGHTS AND MEASURIS ADMIN- ISTRATION}

By C. P. NoRGoRD, Assistant Commissioner of Agriculture and Markets, State of New York

Mr. Chairman and gentlemen, the subject of standards of weights and measures and their enforcement is one the importance of which the general public often fails to appreciate. When the head 
of a family, however, has the experience of purchasing his winter's supply of coal or of paying for gasoline pumped into the tank of his car he has the opportunity to learn how helpless he is in the hands of the dealer and how dependent upon the agencies whose duty it is to enforce the delivery of correct weights and measures in business transactions.

Weights and measures enter into the everyday transactions of every mature individual and each family of the Nation. It is the basis of practically all agreements and contracts and the means of securing equity through them. The delivery of full weight and measure and the elimination of fraud have been and always will be the issue in every transaction from the inception of quantity determinations down to the present time.

Every government from the earliest time has found it necessary to establish standards and to enforce their use as a means of securing just and equitable dealings among its citizens and between them and the State. So fundamentally important has this matter seemed in the eyes of all people back to the most primitive times that the establishment of standards and their enforcement have been among most early nations a part of their religion and the duty of the priests. For this reason also the official standards have been preserved in temples under priestly care. This is seen among the Hebrews in the expression "the shekels of the sanctuary." There is also a record of weights and measures recorded in the Talmud. Many weights and measures standards have been found carefully protected in Greek temples, such as at the Temple of Demeter, of Ephesus, and of Aphrodite. At Rome the standards were kept at the capital in the Temple of Hercules.

Next to its religion, next to the personal health of its people, the most fundamental obligation of the State to its citizens has been that of securing justice among them through the establishment and enforcement of standards of weights and measures. This is exemplified in the emblem of justice, represented blindfolded, dealing out justice by means of a delicate balance.

As weights and measures officials we are therefore dealing with the most ancient and essential responsibility of the State. This historical precedent naturally led to the inclusion in the original Articles of Federation of all the power to fix standards of weights and measures throughout the thirteen original States. This power was later transferred to the Constitution in Article I, section 8, in the language: "The Congress shall have power *** to coin money, regulate the value thereof *** and fix the standard of weights and measures." This constitutional power authorizes the Federal Government to establish standards of weights and measures and keep them uniform throughout the Nation. That power and responsibility of the Government since 1901 has rested with the Bureau of Standards, Department of Commerce.

The action of 19 nations in establishing the International Bureau of Weights and Measures, in 1875, insured uniformity of standards of weights and measures among the nations of the world. Thus has provision been made for this important function and responsibility, not only for this Nation but for the world.

$24342^{\circ}-31-5$ 
It has fallen to the individual States, counties, and municipalities to carry out the duty of supervising and enforcing the use of standards thus established. The States, in many instances, have also assumed responsibility in taking action to establish such standards and practices as have not been set up by the Federal Government, the same to remain until such time as the Federal Government assumes constitutional authority ard thus supersedes State action. The problem before the State is, therefore, how best to organize and carry on and most effectively to enforce the use of standards of weights and measures. Two methods, at least, are practiced: (a) Enforcement by the State alone, through a force of inspectors entirely under State control, and (b) by local county and municipal agencies, under State supervision.

If we wish to carry out the historical democratic principle of home rule, local enforcement is the correct system. Local enforcement has, however, proven more desirable and effective in theory than in practice. It involves enforcement by an official upon his friends and relatives, from which he naturally shrinks. As a consequence, he often evades his responsibility and sidesteps his duty. Experience shows that local politics too often intervene to thwart justice and vigorous enforcement. Too often the position of sealer is handed out as a recognition for political service performed, or to be performed. In many instances also, municipal and county authorities do not appreciate the great importance to the community and its citizens of the sealer's office and of his work. Hence, far too meager salaries and support for the office are allowed for the full-time employment of good and adequate men to carry on the work.

On the whole, experience seems to indicate that enforcement by the State direct is far more certain, unbiased, and effective. Most of the older and more fully organized States, however, already have county and municipal systems, established under State supervision of one form or another. The practical question facing us, therefore, is how best to organize, supervise, and carry out the work through local administration under State supervision.

The questions naturally arise, Why should the State concern itself about local enforcement? Should the State not be satisfied with the kind of enforcement the local government sets up? Are not the local people entitled to determine for themselves what sort of weights and measures enforcement they wish and the amount of money they want to put into it?

Experience has shown that if this principle were carried out literally, particularly in the smaller places, a weights and measures service would result comparable with the quality and condition of jails and schoolhouses found in places where State supervision is not exercised. Improved social, economic, and health measures usually come to local communities from some responsible, specialized State or national agency. Such movements must be brought to those communities through education and, frequently, by the enforcement of State laws. In this way, the State frequently forces local communities and municipalities to tear down old antiquated jails and schoolhouses and build new and modern ones.

In the same way, if we are to have uniformity in the standards of weights and measures and their use throughout the Nation, the 
States must bring to the local communities the standards of weights and measures, interest their local people in them, and get them to establish a county or municipal unit to care for the standards and enforce their use locally.

Experience has also shown that the State, after accomplishing this, can not go away and expect such a system to operate effectively by itself, but it must return to the locality from time to time to stimulate the activity of the local units. Thus must the State exercise constant supervision in order that each local county and municipality may continue to have that high class of service and protection which the most enlightened sections have and which it was the intention of the founders of our State and Nation, should prevail throughout the Nation. In this way is the principle of home rule adhered to, good home rule secured, and uniformity of standards and their use brought about. The question then arises, How extensive shall the State's supervision be and how great the authority of the State over the enforcement of the local units? In New York State, the law gives the commissioner of agriculture and markets charge of the State standards and requires him from time to time to check the condition of standards in local communities. It places upon him the power and authority to establish tolerances and to issue instructions to the county and city sealers binding upon them.

In the exercise of this supervisory authority and because of the inadequate salaries and frequent changes of officials due to political changes, demands from the local communities have come for the exercise of more authority by the commissioner in the selection of local sealers and the determination of the amount of local financial support which shall go toward the salary of the sealer and the support of his office. No satisfactory solution of the requests thus placed with the State has as yet been found. It remains an open and important question needing solution. Upon its proper solution, perhaps, depends to quite an extent the standard of enforcement of weights and measures in counties and in municipalities.

The method of exercising State supervision is one which needs careful study. The New York State law formerly provided that all cities and counties must be inspected at regular intervals, irrespective of the relative needs of the different localities throughout the State. This brought about the inspection of some places where the service was adequate and well supported, like New York, Buffalo, and Rochester, leaving an inadequate amount of the time of the inspectors to devote to supervising and aiding the weaker points that were really in need of help and supervision. As a consequence, the State of New York, by legislation, has now canceled that mechanical plan, leaving it to the discretion of the commissioner as to what places shall be inspected, how often, and how much time shall be given to each. Under this plan emphasis is now being put upon places where the enforcement is poor to the benefit of these places and the service in the State as a whole.

In many of the cities and counties of the State local officials are changed frequentiy. It has been an important part of the duty of the State to send well-prepared inspectors to train new men in the complicated duties of the sealer's office. This is considered a most 
important and proper service of the State and much of the time of the inspectors is devoted to this form of service.

Then there are many cities where very inadequate salary and support are given the office of the sealer, in comparison with the size of the county or the city and the responsibility of the office. The city of Hudson, N. Y., for instance, with a population of 11,745 , invests but $\$ 300$ annually in its weights and measures office. The State is now concentrating its efforts in getting facts concerning the situation in that city and putting them up to the mayor and common council for the purpose of getting an adequate appropriation and a consequent proper service for this important city. Auburn, N. Y., a city of more than 36,000 population, until quite recently depended entirely upon the county sealer to protect its citizens in respect to the use of weights and measures. Consequently, the service was rery inadequate, and the reports of State inspectors after investigation showed unusual discrepancies in the condition of weights and measures and their use. To-day, as a consequence of the activity of the State, there is a city sealer in Auburn with adequate salary and office equipment. Counties are often lax also in support of the work. One county in New York State has failed until the past year in establishing a sealer's office because of an agreement entered into between the two political parties in the board of supervisors not to allow such a measure to pass. Luckily at a recent session of the legislature a law was passed requiring the inspection of all new gasoline stations and pumps before they could be used. This caused such a demand upon the county board of supervisors that they could no longer hold to their agreement and they at last found it necessary to provide for a county sealer.

In this and in other ways does New York State give its attention to finding and improving the weak points of service on weights and measures in the counties and municipalities of the State. The result has been a noticeable improvement in the effectiveness of the service of the State.

The State has also found another form of stimulating activity on the part of local units, namely, by placing emphasis upon weights and measures as applied to some particular important commodity, by means of state-wide drives on such commodities. Outstanding among these have been drives made upon coal and gasoline. All of the inspectors of the State have been placed at work at certain seasons of the rear on these two commodities, passing rapidly from one city or village to another and back again, at irregular intervals. These drives have also been accompanied by proper publicity of the conditions as found, and speedy and reasonably heary penalties applied to offenders. The results have brought about a very satisfactory stimulation of the trade, as well as of the local sealers. One interesting point in connection with these drives is the fact that the requests for them came originally from the best representatives of the trade.

Another method applied in these drires has been that of inviting offenders to attend hearings held at department offices throughout the State, as soon as possible after the offender was caught. This has had the effect of making punishment swift and suited to the offense and has given an opportunity to meet the offender and to explain to him the provisions of the law and to convince him of their necessity. 
Through these various methods it has been found possible to inprove State supervision and service on weights and measures in New York State without the use of a very large or increased number of inspectors.

\section{THE STANDARD CONTAINER ACT OF 1928}

By. H. A. SpLmax, Senior Marketing Specialist, Bureau of Agrioultural Economics, United States Department of Agriculture

Mr. Chairman and gentlemen of the conference, since a representative of our office talked to you last year, the standard container act has become effective; so far as the penalty provisions are concerned that happened on November 1, 1929. We had a little more trouble at the time the act rent into effect than we had expected to have due to the drought of last summer. The dry weather which prevailed over a wide section of the country resulted in the carrying over of a large number of nonstandard containers. This occurred principally in connection with the 14-quart hamper used in Connecticut and some other parts of New England and in northeastern Pennsylvania, and with the 28-quart hamper used in Florida and Mississippi. We received inquiries as to whether some arrangements could not be made to use these hampers up during the present season. Of course, there was only one answer-that there was no provision to waive the penalty prorision. We realize this has worked a hardship in many instances. One man in Tennessee had ten thousand 28-quart hampers early in the season and could not dispose of them. Seventeen months, two growing seasons, had been allowed the parties affected to accommodate themselves to these provisions. But you gentlemen know the tendency of people to hang on to a short measure until the last minute it can be used.

The trouble in Connecticut with nonstandard containers was due to a misunderstanding. A lot of the Connecticut farmers felt they could continue to use them and it took 10 days' work of three of us to make some start toward clearing up the situation. We also found some trouble in the city market of Scranton, $\mathrm{Pa}$. The dealers there said that they had been informed that they could use those measures.

Another difficulty occurred in Florida and was due more to the ignorance of the manufacturer than to intention. Hampers have their capacity determined to the upper edge of the inside hoop. In Florida it is customary to set the cover down so that it fits into the hamper. In Tennessee there is a tendency to have the cover on top. Naturally, if you take a basket that is intended to have a cover on top and you insert the cover it will be short and that has been where we have had trouble. We got one man in Florida with 50,000 that were short and we made him ship them up in Tennessee with covers large enough to fit outside. We would have put two factories into bankruptcy if we had not been tolerant, and we believe the solution we adopted was the proper one. We found one case in Pennsylvania in which 15-quart hampers had passed into the hands of farmers, after we had notified the manufacturer that they were short capacity. These hampers were made before the 1st of November, but had not been used. In some cases the farmers had paid for the hampers, and we did not care to see them suffer. In this case the manufacturer has agreed to replace all those nonstandard hampers with standards, 
and our decision to prosecute is being held in aberance until we find out what he is actually going to do.

We have had one or two cases of an erasion of the law on some types of containers and inrestigations are now in progress on those. We have accumulated considerable evidence against one indiridual, who is due, I think, for a surprise before long.

In our work on standard containers we hare alwajs had the cooperation of the manufacturers-me expect to have it in enforcing this law, and have had it to a great extent. The provision in this law that manufacturers must submit their specifications for approral has made fellows in the basket industry who formerly nerer thought anything about dimensions or specifications get down to brass tacks on that phase of the matter, and I beliere that we will hare rery little trouble.

We hare not had the cooperation of the manufacturers of basket machinery that we expected. and we found that certain were continuing to put out forms which when used by the basket manufacturers would not permit them to make proper size baskets. There is nothing in the law which will permit us to touch them. Howerer, we hope it will be ironed out in time.

The provision in regard to the approral of specifications is responsible for the great bulk of the work in our office in the last two years. It has entailed the examination of 550 sets of specifications and the testing of 7.374 baskets to determine whether or not the manufacturers' baskets do lire up to their specifications.

Now, of course, the department, under the standard container act of 1928. is doing considerable work. but that is not all that we do. We still hare some testing under the standärd container act of 1916 , and figures show that from July 1, 1929, to May 7, 1930, we tested 1.191 containers under the standard container act of 1916 and $4.32 S$ coming under the act of 1928, a total of 5.519. For a similar period last rear 3.626 containers were tested. This mechanical work takes up considerable time, as those of you who hare had experience testing baskets well know. Of course, there is nothing norel in our method of testing. Te use bulk for bulk, as outlined br the Bureau of Standards, although we have special apparatus to quicken the mork. Our methods, by the $\pi a y$, are described in a miscellaneous publication which came out last week, which was written at the suggestion of Mr. Miller, of Indiana, and which each one of you should receire. We think tre hare obtained a rery complete list of sealers of reights and measures, and that publication will be sent out to pou just as rapidly as enrelopes can be addressed. If you do not receire one, please write in and let us know.

There are sometimes, of course, unfortunate developments which arise when new pieces of legislation are being put into effect. As Mr. Perkins said awhile ago, it is a rery difficult thing to pass remedial legislation which is satisfactory to ererybody and accomplishes ererything you wish to accomplish, and which at the same time does not add some things which you do not want. That is true of this law. There are two things which we would like to see changed. One of them is the lack of a prorision as to the marking of containers. It was in the bill at one time during its historr. You know, howerer, that the bill hung fire for eight years before it 
was passed, and was rewritten at almost every session of Congress. Thus at one time it contained a provision requiring the marking of all baskets which came within its purview. But at the insistence of a manufacturer of splint baskets, that was stricken out in committee and was never restored. Now, I believe we could secure the approval of the majority of manufacturers for the inclusion of such a provision and we believe marking would be highly desirable in order to assist the average local official who has had any experience with baskets at all in determining whether a basket is short in capacity. That is one of the ideas that we had when we started the administration of the law-that we should make as simple as possible the determination of whether or not baskets came within the standards. Thus far we have been able to give only tentative approval to baskets and no final approval can be made until we make tests on baskets from the ordinary run of production instead of tests on those made with their correctness and appliance to specifications especially in mind. After we have entirely completed the work of approving specifications, production tests on baskets can begin and this work will be started very shortly. We intend to give publicity to these results, and, as I said before, if markings were required, this would not only simplify the identification of the manuracturers of baskets but we would make possible a much closer and highly desired cooperation between the State and local officials and the Federal department.

We have gone as far as we could under the regulations. We have provided a method of marking which a manufacturer may use if he wishes. We did that on the ground that since the manufacturer was required to submit his specifications for approval he should be permitted to indicate in some way that approval had been obtained. Most of the manufacturers, will, I think, avail themselves of that method of marking, but the manufacturers of splint baskets, which need marking most, have shown some disposition not to do that. Of course, any basket manufacturer objects to anything which increases the cost of operation. With machinemade baskets it is comparatively easy to develop a method of marking by machinery in some state of the process and not add greatly to the cost. Splint baskets, however, are almost all handmade and are sold on a very close margin, and these manufacturers, naturally, have rather consistently objected to marking. In fact, it was a splint-basket manufacturer who caused this requirement to be taken out of the bill several years ago. We believe that the law would be bettered were it to be amended so as to require marking, and, as I have stated, we believe the majority of the manufacturers would support some such proposal.

There is one other matter in connection with this law which I know you have thought over a good deal, some of you perhaps, in bitterness of spirit. It appears according to the lawyers, that this law did something that no one thought it would do. We have had occasion to seek interpretation of several points of the law from the Solicitor of the Department of Agriculture. In one of the general opinions which he gave us, he used certain language which made it seem that inadvertently this law tends to nullify a great deal of the work that has been done over a long period of years in the bringing 
about of sales by weight, or the sealing and certification of dry measures where these are employed. Nothing, of course, was further from the minds of those of the Department of Agriculture who were interested in this matter, than any such development. The Bureau of Agricultural Economics, while it has never believed in sales by weight per bushel-a matter which was discussed here last yearhas always believed in retail sales by weight or by numerical count. In a Farmers' Bulletin which we issued several years ago we called particular attention to the Massachusetts law on the subject-the law which has since been enacted also by New Jersey and Indiana, possibly by other States-which specifically requires sales by weight or count, except when in the original container.

We believe it would be a tragedy to have this law used by anyone in an attempt to evade State or local laws requiring sales by weight, or sales by standard dry measure. Certainly none of us would argue for a moment that it would be proper to take a standard hamper or a standard bushel basket and use it over and over again as a measure for fruits and vegetables. We do not believe that is the proper use of that sort of a container. Neither do we believe that so sensible a proposition as sales by weight at retail should give way to sales in which small baskets are used as measures over and over again. Now, we have kept pretty quiet about that interpretation of this law, but we found that some dealers in some markets apparently were smarter than we were. They saw the loophole before we did, and we heard from some few of the weights and measures officials that use was made of it. We have attempted as far as possible to discourage such use of the law, and Mr. Carey and myself, representing our bureau, and Mr. Holbrook and Mr. Smith, representing the Bureau of Standards, have had several conferences in an effort to draw up an amendment to this law which would safeguard everything which we wish to accomplish by the law and which would, at the same time, safeguard what has been accomplished by weights and measures officials throughout the United States in bringing about sales by weight.

We have again found it is a little hard to draw up something which says what you want to say and does not have other implications. The Bureau of Standards propnsed the first amendment; we countered with another one; then a lawyer produced a third; after we got through we concluded that all we had accomplished was to kill the act without making certain we had done what we had intended. We finally put three suggested drafts up to the Solicitor of the Department of Agriculture and have been waiting prayerfully, hoping for some action from that office. It happens that that part of the solicitor's office has been very busy for the past few months on court work, and I regret to say that they have not got anything definite that I can present to you to-day.

I do. however, want to arouse your interest in the matter, and hope that we fellows in the Bureau of Standards and Bureau of Agricultural Economics will have your interest and hearty support.

The ChaIRMan. The subject of the standard container act of 1928 is one of very great importance to this conference, and we are indebted to Mr. Spilman for his clarifying statements. After we hear from Secretary Klein, we will open the meeting for discussion of this item. 
I am glad to say that Secretary Klein, of the Department of Commerce, has just come in. Most of you know that he was Director of the Bureau of Foreign and Domestic Commerce after having served his apprenticeship in several foreign stations; he is the Assistant Secretary of Commerce during the present administration. There is no one man in the department whose name stands for more in commerce than Doctor Klein. Doctor Klein, I may say to you that your audience here is an audience of representatives from 27 States and several departments of the Federal Government.

\section{ADDRESS BY THE ASSISTANT SECRETARY OF COMMERCE, HON. JULIUS KLEIN}

Doctor Burgess and ladies and gentlemen, I need hardly say that I feel honored indeed to have been given this opportunity of greeting you in behalf of the Department of Commerce, and of having at least a glimpse of your proceedings out here. We in the department, as Doctor Burgess has told you, feel particularly complimented when busy officials and business men take time away from their troubles and cares and come down here to Washington, and we have provided as warm a welcome for them as has been possible.

The importance of your problem, the familiar question of the uniformity of weights and measures, is perhaps best typified by this very institution which we are now visiting. The Bureau of Standards had its origin as the custodian of the weights and measures of the country. You have only to look around you, noting the amazing proportions to which this institution has risen, to get some grasp of the profound significance of the weights and measures problem, because that, as I have said, was the germ out of which this vast and invaluable organization has developed. Furthermore, the bureau illustrates to a peculiar degree the chief purpose of your conference, namely, collaboration between industry and Government, not solely Federal Government but State and local government; and there we have, again, in the bureau, an admirable illustration of the necessity for that type of detailed work. Government in these days can not sit down and arbitrarily rule and order things. To an increasing degree, thoughtful persons have been realizing through the past few decades (and more particularly in this period since the war) the prime necessity of keeping Government in close contact with industry; and this bureau stands as an excellent illustration of that type of thing applied to the realm of reality, making sure that Government does take its orders from industry and commerce and that it does provide practical and concrete service.

Of course, you can not get very far in that principle unless you keep assured of a reasonable degree of organization within industry. In a country as vast as this, and with as complicated an economic system as we have, it would be manifestly impossible for any governmental agency to accomplish its objective if it had to deal with each individual firm or each individual person engaged in certain lines of industry or trade. You must have organizations to deal with, and that is one reason why we are so fortunate in this country, because the American is "organization minded," so to speak. Of course, it is the pet diversion of our professional critics at home and 
abroad to weep mournful, melancholy tears because the American is gregarious to such an extent that we might put two Americans on a desert island and they would immediately organize a chamber of commerce, or a Kiwanis Club, or some other get-together group. There is undoubtedly a great deal of back slapping and "elbow greasing" of that sort, but these 13,000 trade associations that we have in the United States are, I am persuaded, one of the chief reasons for the amazing stability of our economic organization, one of the reasons for the notable commercial relations that we have established throughout the globe. That very gregariousness which is the butt of so much sarcasm is one of the reasons why we recovered from the war-engendered depression in 1921 and 1922, and I am sure that if other parts of the world had been blessed with more organization instinct they would have made a much more rapid recovery than they did. So here, and particularly in this department and this bureau, we could not get anywhere unless we were able to deal with organized industries, who communicate their problems and enthusiasm, which in turn is translated into action during the deliberations, resolutions, and ideas that develop through meetings such as these.

Your conference, furthermore, typifies to a peculiar degree the further advancement that is aptly illustrated by the collaboration between the States and the Federal Government. Government in all things should set the best example and stand for the best effort for collaboration within its various units, whether they be national or local, in one form or another. Of course, weights and measures are the rules of the game. Simple uniformity in those rules will, however, not get us far. We are very apt to pat ourselves on the back because of the solid area of the American Republic. Our European friends do not disguise their admiration for the "uniformity of action" of this great country, the way we can plunge into any great cause and all line up together. The recent attempt to perfect the United States of Europe is about as frank a piece of flattery as you can imagine, considering the economic, political, and racial differences between the various countries. Conditions there are entirely different from the situation in this country, where, in fact, barriers do not exist so far as economic and commercial matters are concerned. But any study of industry and trade in this country brings out the truth that we are not as homogeneous as we would like to be, and your very problems here (trying to make more uniform the weights and measures procedure throughout the country) admirably illustrate that very point.

Just last week we had a conference on street and highway safety, and once again the idea of making more uniform the regulation and practices in reference to traffic were considered. One apt illustration of the need for such uniform regulations is the fact that if one were to drive to New York, a distance of 250 miles, and observed the Washington regulations, he would be jailed probably 285 times on the way, or else he would get those unpleasant red tickets by which we are assessed according to the laws of the realm.

We are homogeneous up to a certain point, but by no means completely so. We can match in this continent of ours conditions in almost all parts of the world, except, of course, the extremes of the 
Tropics and the polar regions. When an American manufacturer wants to sell tractors in Australia he knows what conditions will be met in that country, which is quite similar to Arizona and $\mathrm{New}$ Mexico, where his tractors have been sold and used. In the Argentine again the manufacturer is on old and familiar ground because the pampas are like western prairies; and, with respect to almost any foreign markets, he can be guided by comparable conditions within the United States.

Will Hays once told me why the movies are so successful. About 25 per cent of the revenue of the industry comes from foreign royalties and foreign trade. And we enjoy certain distinctive advantages in catering to world audiences. When you put on a mob scene in Los Angeles you go out and get whatever type of mob you need. If you need Irish, they are there; and if you desire a Spanish crowd, you have it. But let any German manufacturer go out on the streets of Berlin and try to get an Irish mob; he will probably fail in the attempt. And the same is true of an English competitor who wants to put on a Spanish scene-he will have a hard time of it. So this lack of complete homogeneousness has its advantages.

There are differences in rules and regulations and standards of industry in different parts of the country. We do speak the same language, more or less, but the more I listen to my loud speaker the more I wonder how we are understood. We are not as homogeneous as we might be, and that condition lends itself to the effort you are making here to bring about something like uniformity in this very important field.

A rubber yardstick is, of course, a direct incentive to fraud. That is obvious; but I often wonder how far-reaching is the effect of such iniquitous practices. The rubber yardstick, for example, also has a malevolent influence in that it slows down industry, in that it makes caution necessary and retards business; and such an effect is especially injurious in this day of swift reactions in trade, of an everaccelerating development in industry and commerce everywhere, which has been, perhaps, the outstanding economic development since the war.

The Bureau of Standards collaborated in the work of a committee engaged in the preparation of a report entitled "Recent Economic Changes"; and the salient finding of that committee is that business is not so different in so far as institutions are concernedthat is, the installment plan is an old thing-people have been buying and selling harvesting machines for generations-chain stores were in operation 70 years ago-and there is hardly a thing in business and commercial practices that is new-the big thing is the fearful acceleration of operation, acceleration of delivery through the laying out of bus lines everywhere, through the improvement of highways, and the amazing multiplication of automobiles. The airplane has also helped to speed up business. All this speeding up of business is an inevitable factor in our whole life. Anything which tends to slow it up is contrary to the public interest, and inadequate weights and measures are a formidable factor of that sort.

Five years ago Mr. Hoover spoke to you, and some of you may recall an illustration he used. He said that there were about a dozen types of 1-inch board. Well, 1-inch ought to be an inch everywhere 
and under all conditions, but until recently there were different types of inch used in board measure, whether it was an inch in a plank planed on one side, or on both sides, or in other different kinds of board. This meant more checking, slowed down business, and brought about other difficulties.

We are priding ourselves on mass production, on the amazing volume of our industrial output, and, of course, along with that will go mass distribution. We could not get anywhere at all with our schemes of volume production unless we could also sell in large quantities; and that means, of course, quickness of turnover, which must be accompanied by uniformity of weights and measures and the prevalence of dependable standards. There is a great necessity for uniformity of sizes of containers in the units that are now prevalent. If doubt is raised in the minds of the housewife or the trade in general, there is bound to be a slowing down of business which may be disastrous.

To an increasing degree, business these days is a matter of credit. We no longer sit down and haggle with people and swap in the David Harum manner. Those days of horse trading are gone. Debts are paid to-day by little slips of paper-drafts or checks.

Credit is only another name for confidence, and you can not have confidence if there is the slightest question about the first essentials involved, namely, the weights and measures of commodities concerned. In the old days, in horse trading, you could examine the horses, look at their teeth, and make sure what you were getting; but with credit and confidence playing so large a part we must take a great deal on faith and that means, of course, as the first essential of marketing, knowing what the units of measurement are in every case.

Take the last "late umpleasantness" in the stock market. That was due mainly to a failure on the part of the speculators, both amateur and professional, to measure carefully and accurately the relationship between the earnings of the corporations and the quotations of their stock on the exchange. It was a simple problem in measurement. In that case it was necessary to have a definitely fixed yardstick to gage such operations. A number of statisticians were informed, but the average amateur in the field of speculation did not realize the necessity of being guided by such tabulated schedules and reports. Consequently, when the crash came those amateurs wero totally unprepared to meet it, and as I have said, it occurred primarily because of a failure to observe the ratio of earnings to the quotations.

The inability or the incapacity to judge those realities in business, to apply carefuliy such yardsticks, is certain to lead to disaster. We can not go on in a state of perpetual opulence.

There is, of course, the inevitable danger of expecting too much from the apparatus or processes which you gentlemen set up in your deliberations. They form simply a means to an end. And they must be properly and sensibly used. We can not expect that, after you have decided upon uniform measures, the job is done. Those are simply vehicles toward an uitimate purpose. We can not expect, with the highly complicated economic requirements of the present day. to reach salvation through devices of that type. They are indubitably 
important, but they do not accomplish everything. They are not capable of such summary, symmetrical application as the ancient Egyptian Nileometer. The Egyptian authorities would go down and look at the Nileometer and observe the height of the water, and from the height of the water they would.calculate the assessment of taxes for the year, because the height of the water had a direct relationship to the flooding of the land, to farming and grazing, and, therefore, to all assessable properties. It was all very simple to them. But Mr. Mellon has a more complicated job these days.

One of our very alert statisticians down in the Department of Commerce calculated that the rate of exchange of the Colombian peso was influenced by the height of the Magdalena River. $\mathrm{He}$ found there was a maximum of three months' time during which the Colombians could bring coffee out. On that basis one could calculate with reasonable accuracy. The same is true of a great river in the region of Saigon in Indo-China. The height of the level of the river has a direct bearing on the size of the crop and consequently on the purchasing power of the people in that area. But in an economic order such as ours it would be rather dangerous to presume to set up such a yardstick on which you could calculate any considerable portion of our general business.

Many statisticians and others have given us prophecies and hope as to the future trend of business. In an unkind moment one enterprising young statistician went over the prophecies made by these propheteers and discovered that they were right just about 50 per cent of the time. That occurred some two or three years ago, and it is hoped that they may have improved.

There are any number of problems before us, and I do not want to enumerate many of them. But unless we do keep close contact with them, we will have the same trouble again and we will have our recovery materially retarded. We must not expect an instantaneous increase in prosperity once more. We must not expect that, simply because some very interesting and helpful conferences were held in Washington, everything will become lovely at once. It will take a considerable length of time to come out of the effect of this last depression, and it will involve divergent factors. Take this matter of construction: Because there have been a very large number of contracts let this year, it does not mean that June and July will be immediately prosperous. The results of such contracts are not instantaneous, not immediately evident, as it takes some 6 to 10 months to put contracts for construction into effect, and the effects are felt months later by the rank and file of industry in general. The "lag" is just about that. In fact, the president of a large radiator company, in one of our conferences here, brought out the fact that usually the construction business ran just about 8 or 10 months ahead of the usual normal level of the rest of the business world. In other words the building trades were having hard times and getting into trouble as far back as November and December, 1928, and consequently when the crash came along in October and November of 1929, informed persons were not at all surprised. Even now, with the sagging money rate and the consequent picking up in construction, it will take 8 to 10 months before we find the full effect of that program which was launched in January. Consequently, 
there are a great many who seem to feel that it will be pretty near fall before we see any material improvement in business.

In the department's relation to industry and commerce, our business is not to prophesy, but simply to report what has happened; and we are not trying to hand out any panacea as to how betterment may be brought about. Industry is learning a salutary lesson as a result of its recent experiences. We must meet competition, which is keen, not only in foreign markets but in the domestic field as well. That brings out the element of changes in procedure and practices in the larger industries, due to the introduction of synthetics. One of the most potent factors in industry is the quiet chemist who, sitting in the midst of his smelly test tubes, suddenly develops something which will upset great industries overnight. A very powerful impetus has been given to chemistry through the war and postwar research, so that any manufacturer is foolhardy if he is more than 24 hours away from good sound chemical advice. Any business man who is sitting smugly, feeling that his business is secure, and that his competitors can not make any "silk purse out of a sow's ear," is very foolish indeed. A great chemical engineer not long ago took that axiom literally and actually made a purse out of a sow's ear. He took some ears from the porkers and developed them into a viscous solution, and the final outcome was something that looked like a silk purse. It was a process such as is used in manufacturing cellulose products.

The business world is utterly different from its former aspect, and is constantly changing; and it is of the utmost importance that we observe these changes and appraise their practical application. 'Take the example of style changes. It was perfectly safe for manufacturers in the old days to sit down and reel out millions of yards of goods because the yardage was pretty much the same, year in and year out, and decade in and out. But since the war no one knows what the style will be, and it would be a foolhardy manufacturer who assumed that the conditions would remain in status quo.

We had at the department one especially striking illustration of style changes and of the supreme importance of watching the consumers. About four years ago certain textile manufacturers in Nerv England were in distress, and we asked where their market was. They did not know. They had handed their goods over to certain distributors and then forgotten about them. They now realized that it was important for them to know the ultimate consumer's buying power. We traced the merchandise movements and found that their marizet was out in the northern part of China. The buying power of the people had collapsed, simply because the leading industry, which was the manufacture of hair nets out of human hair, had collapsed. It so happened that a lady named Irene Castle bobbed her hair; thereupon 14,000,000 women did the same, and the hair-net business went "up the spout."

Now, is it too much to ask a manufacturer to keep watching his market and note all changes that may take place in it? Ask the first shoe manufacturers you see regarding their business outlook. They will probably tell you that the situation leaves much to be desired. Some of them failed to capitalize their opportunity and are apparently not keeping up with progress. Just the other day the largest 
competitor in Czechoslovakia gave a good illustration of how industrialists are "on the job" in that country. He has representatives in the United States making photographs and designs, which are in turn flashed across the ocean in radiophotographs, so that he gets them immediately and can guarantee delivery in 10 days in this era of rapid transportation. That manufacturer has become imbued with the idea of being unfailingly vigilant and brisk-keeping up with Father Time. Father Time is no longer an old, doddering gentleman with a white beard, wrapped up in a white robe. $\mathrm{He}$ is a fast-stepping competitor who has shaved his whiskers because they interfere with the streamline effect; and unless the American manufacturer can show comparable speed, he will soon be left by the roadside. The changes now taking place are vital; any business men who are not alert will be left flat-footed.

These changes are going on everywhere, and that fact further stresses the importance of this Bureau of Standards. Those things that are immutable, the weights and measures and yardsticks and categories and schedules upon which this conference is deliberating are factors that should provide at least some foundation for reasonable security and permanence; otherwise, despite all the speed in trade and industry, we will get exactly nowhere.

Let me repeat that we in the Department of Commerce are glad to see you here and know that your activities will be of the greatest benefit to commerce and industry and the people of the country in general.

\section{FIXING OF EFFECTIVE DATE OF SPECIFICATIONS AND TOLERANCES FOR GREASE-IVEASURING DEVICES}

Mr. Foley. Mr. President, yesterday while we were gathered in this conference, we had quite a discussion as to whether or not the conference would allow an extension of the time at which the specifications and tolerances for grease-measuring devices are to be put into force and effect-a postponement of one year was asked for. We showed these different men where they could get off and that we were serious about this proposition; it seems to be the unanimous opinion with all of those to whom I talked that we had won a victory, but a rather empty one. After all is said and done we hold the whip, we are in the driver's seat, we have the upper hand. These men have not made as much of an effort to comply as we thought they should. I am with our brother from Richmond, Va., Mr. Ragland, and was with him from the start. However, we discussed this thing last night and thought maybe we were a little too severe. In the past 60 days there has been a great movement to get together to solve their problems. We have also solved ours by making rules and regulations that they must live up to. So I talked to as many weights and measures men as possible-I am sorry I could not get to all-and I said, "Boys, let us be magnanimous." Now I am going to ask you, Mr. President, to deviate from the program for a few moments while I make a motion and I am going to ask Mr. Ragland to second it. The motion is this:

I move you, sir, that this conference allow the equipment men six months from July 1, 1930, to make the necessary experiments in their equipment and to bring about the necessary changes to make it comply 
with specifications and tolerances, and to give the oil industry the opportunity to meet the conditions that prevail, and that at the end of that period we may confer at the call of the Chair to determine whether or not a further extension of six months is needed.

With your permission, Mr. Chairman, I will ask Mr. Ragland, of Virginia, to second my motion.

Mr. Ragland. Mr. Chairman and gentlemen, as a matter of personal privilege I want to thank you for your attitude of yesterday. I appreciate very much the unpleasantness of the occasion and must say that of the many years that I have come up here, yesterday you were more considerate than ever.

As far as my friend, Harry Foley, is concerned, and as far as the city of Richmond is concerned, we will still enforce the code, but I an perfectly willing to second the motion of Mr. Foley. Next year I will come up here, and I want you to say he was still magnanimous.

Mr. Griffith. Mr. Chairman, I took the trouble yesterday to read over the deliberations on this subject as recorded in the proceedings of the conference of 1929. In the report on the code of specifications and tolerances for grease-measuring devices there is a discussion of policy involved in the date of adoption and enforcement. It is a policy that has been established by our very capable secretary and, as I recall it, briefiy, that policy involves a tentative adoption, a period of 1 year before final adoption and a period of some 13 months after final adoption before the code is to be put into force and effect. In the discussion that arose at that time it was decided that that should be ample time for the manufacturing industry, the oil industry, and the weights and measures officials to accommodate themselves to the changes necessitated by the code.

Now, with this motion to extend this time six months additional. with the possibility of it being extended six months more, we are creating a precedent to which I' can see no limit. Of course, if it is not possible for the industries to procure the equipment, then it would not be possible for the weights and measures officials to force compliance with the code; we naturally have got to take into consideration facts as they exist. But, as I was informed yesterday, there are machines-not one, but many-which do comply with the regulations and specifications, and if that is the case we should not deviate from the definite policy of this body.

Mr. HoLbrook. Mr. Chairman, I may say for myself, personallyand I think I can also speak for the committee in this relation-that this is a very exceptional case, and no objection will be raised to the proposal for an extension in the matter. If any member of the committee disagrees I would like to have him say so now.

Mr. Ragland. Mr. President, my good friend Captain Griffith and $I$ believe in giving and taking. I am the man who agitated all this trouble. I am enforcing the code and Harry Foley is enforcing it. I am enforcing it and I will make it even tighter in Richmond, but I think courtesy compels this motion.

The Chamman. You have heard the motion made by Mr. Foley and seconded by Mr. Ragland. Are there any remarks?

(The question was taken, and the motion was agreed to.) 
The Chatriran. You remember we postponed discussion on the very important standard container act. I think Mr. Spilman is still here. Have any of you any questions you would like to ask Mr. Spilman.

Mr. Foler. Mr. Chairman, we are very vitally interested in one phase of the paper presented by Mr. Spilman. New Jersey was practically the first State to adopt the sales-by-weight law. Last year we had considerable discussion regarding the paper presented at that time and it seemed that New Jersey was rather out of luck in its enforcement of its law. As I understand the situation, the paper this morning dealt practically with the manufacture of these containers. Toward the conclusion of his talk, Mr. Spilman brought up the matter of sales by weight as being one of the problems which the Bureau of Standards and the Bureau of Agricultural Economics was confronted with and was trying to solve.

Now, our act provides for sales by weight. We have no legal weight per bushel in the State. All dry measures were legislated out of business for use as measures. We have an act of our own regarding the standardization of baskets which is separate entirely from the sales-by-weight law. Now, in the discussion last year as I recall it, if a farmer packed a standard bushel hamper he could use that as a measure. We allow an original container to be used to determine the amount to be delivered therein in the case of certain commodities, but we have legislated out all dry measures, used as measures. Now, are we still in the same position as we were last year? We have not had any difficulty as yet, but some of the wise ones, as you stated during your talk this morning, are using containers as measures. However, our State commission has ruled that the standardization of the container does not make it a measure but a package.

I would like to get clearly before the conference, that in those States where a genuine sales-by-weight law exists, we do not want to take exception to the Bureau of Markets, but I think we will go along as we are until they hale us into court and get a decision.

Mr. Spilman. I only wish you more power in getting across the sales-by-weight proposition.

A Member. Mr. Chairman, may I ask Mr. Spilman whether or not this standard container act does make a container officially a legal measure?

Mr. SpIlman. In an interpretation of the law the Solicitor of the Department of Agriculture held that it did.

\section{APPOINTIMENT OF COMIMITTEES}

The Chatrman. With the consent of this conference, the Chair at this point will appoint the following committees:

As the committee on resolutions: A. B. Smith, of Pennsylvania, chairman; J. H. Foley, of New Jersey; P. D. Dukesherer, of Michigan; S. H. Wilson, of Georgia; Thomas Flaherty, of San Francisco, Calif.; James A. Sweeney, of Boston, Mass.; and S. T. Griffith, of Baltimore, Md. 
As the committee on nominations: Francis Meredith, of Massachusetts, chairman; I. L. Miller, of Indiana; George Warner, of Wisconsin; B. W. Ragland, of Richmond, Va.; and W. A. Payne, of Monroe County, N. Y.

There is also a vacancy on the committee on uniformity in weights and measures requirements, to which I will appoint V. A. Stovall, of Texas.

\section{THE SALE OF CHEMICALLY TREATED COAL}

\section{By I. L. MILlER, Commissioner of Weights and Measures, State of Indiana}

Mr. Chairman, ladies and gentlemen, invitation to present this paper was received rather late and I rather hastily accepted it, having in mind that about a year ago chemically treated coal first came to our attention and at that time I made somewhat of an investigation and found information rather easy to obtain. I thought it would take only two or three hours to run down town and get some data and then write up what I had found. Very much to my astonishment, among the dealers serving about 400,000 people I found only one dealer who was actually chemically treating coal. I do not mean he was the only one selling chemically treated coal, but he was the only one applying the chemical in his establishment. The others were handling coal treated at the mines. I had no opportunity to find out about the treatment of coal at the mines.

Chemical treatment of coal for domestic use for the purpose of allaying dust is comparatively a new development. The treatment adds nothing to the fuel value of the coal, but is intended solely to eliminate the dust nuisance both while delivering and in handling while firing. Dealers, who have sold treated coal and those persons who have purchased and used it, are apparently unanimous in their opinion that the treatment effectually serves the purpose intended.

Dealers and weights and measures officials in whose jurisdictions chemically-treated coal has been sold have been much concerned regarding the proper method of its sale. Some officials have insisted that the dealer should make allowance in weight for the added moisture from the treatment. Dealers who have sold the treated coal insist that it is a distinctive article and should not be so penalized. On the other hand, some dealers in untreated coal insist that they should have the privilege of adding moisture, in the form of water, if no deduction of weight is to be made for moisture in treated coal. The question of weight deduction in the case of treated coal was referred to the Indiana State Department of Weights and Measures early in 1929. At that time the department indicated its attitude in a reply to an inquiry from a coal company applying the treatment, as follows:

In view of the fact that in the process of the chemical treating of coal the weight of added water and chemicals varies rather widely but, perhaps, in no case is extremely large, and in view of other questions that have arisen as to the effect of the chemicals upon furnaces and stoves, the department has decided that the sale of chemically-treated coal under names that will indicate clearly that the coal has been treated, is of more importance to the purchaser than a small deduction for added weight. We are, therefore, of the opinion that all treated coals should be advertised and sold under names that will plainly indicate their nature. Such coals are not "dustless" and should not be sold as such, since all the dust is still present but in a form that does not cause inconvenience in handling. 
Chemically-treated coals have been sold almost universally as "dustless." "The dictionary defines "dust" as, "fine, dry, particles of earth or other matter so comminuted that they may be raised and wafted by the wind; that which is crumbled to minute portions; fine powder." According to the first meaning given, the adrertiseinents hare been correct, since the finely divided particles are no longer wafted by the wind. It is doubtful, howerer, if this is the complete thought conveyed to the purchaser of coal who reads the advertisement for "dustless" coal. It is just as reasonable to assume that the purchaser accepts the two last meanings mentioned in the definition-that dust consists of finely divided particles, or is a powder-and assumes that "dustless coal" means that the fine particles or powder have been remored. Because of the possibility of misunderstanding arising regarding the meaning of the term "clustless coal," its use is inadrisable.

The chemicals used in the treatment of coal are deliquescent; that is, they have the ability of absorbing water from the atmosphere or other sources. Calcium chloride forms the basis of all the compounds which have come to the attention of the weights and measures department. One local dealer stated that he used a saturated solution prepared from the crystalline calcium chloricle. A company supplying the treatment states that their compound is composed of three elements, all of which are dust layers. Another proprietary compound is claimed to consist of calcium chloride treated in such manner that the solution made from it has increased viscosity, increased capillary or "wetting" action and is so neutralized that it does not injure the metal of furnaces and equipment. Magnesium salts have been used in combination with calcium chloride. The United States Dispensatory describes.calcium chloride as "odorless, having a sharp saline taste and very deliquescent." According to the same authority 10 parts by weight of calcium chloride dissolres in 12 parts of water at ordinary room temperature. It will be recognized that calcium chloride is the clust allaying agent used by some State highway departments for the treatment of earth, gravel, or stone roads.

The benefits claimed for the calcium chloride treatment are, first, no dust. Coal wet down with water dries out, but coal treated chemically remains free from flying dust for at least one year. Second, reduced smoke. The treated coal has a tendency to burn cleaner and better. Third, reduced slack. Chemical treatment tends to seal, to a certain extent, moisture in the pores of the coal, thus reducing slacking.

One of two types of apparatus is generally employed in applying the chemical to the coal. The simpler type consists of an elevated tank in which the solution is prepared, and an attached hose equipped with a spray nozzle through which the solution is applied to the coal. The more efficient type includes a tank, pump, and electric motor, together with the necessary high-pressure hose and spray nozzles. In this type the tank is equipped with a special agitator which mixes the water and chemicals. The solution is then pumped through a hose with spray nozzles under a pressure ranging up to 300 pounds.

Three methods of treating coal are in general use. In the first method and the one which is perhaps the least used, the solution is sprayed upon the coal after loading into the truck. It is evident that this method is also least efficient, since the chemical is not evenly 
distributed throughout the load. In the second method of application the spray nozzles, two or more in number, are attached at the top of the elevator used in conveying the coal from the car into the dealer's bin. This method is very efficient, since all the coal receives an even spray of the chemical. In the third method the chemical is applied at the mine in the same manner as just described in method two. Treatment at the mine seems to be most popular with the retail dealer since the larger portion of treated coal sold is mine treated.

The cost of treatment varies somewhat widely according to available data. One company marketing the prepared saturated chemical solution which requires dilution with 11 parts of water, claims that coal in lots of 500 tons can be treated by the dealer at a cost of 6 cents per ton. Another large manufacturer states that the cost is about 25 cents per ton in the case of low volatile coals and from 15 to 20 cents per ton in the case of the harder coals. The only local dealer consulted states that the cost ranges up to 25 cents per ton. This dealer says that while previously his company had charged the purchaser 25 cents per ton extra for treatment, for the past year no difference in prices had been made between treated and untreated coals. Similar reports have been received from other dealers.

The weights and measures official is particularly interested in the effect of chemical treatment upon the weight of coal. Manufacturers and distributors of chemicals and chemical compounds for coal treatment have stated that the weight of added water and chemicals does not exceed 40 pounds per ton. The average is perhaps around 30 or 35 pounds per ton. In the case of one load of coal in which the process was observed, the added water and chemicals amounted to 35 pounds per ton. It is believed that these figures are very nearly correct.

Abuse of the practice of chemical treatment of coal is suggested by one large distributor of the treatment compound. After mentioning the treating of' slack, this manufacturer states that " many dealers sell this dustless slack as such, while others find that a few shovelsfull to the ton of regular coal is satisfactory, and they get rid of it that way." This amounts, of course, to adulteration, since a very cheap product is added in small amounts to one that sells at a much greater price.

All manufacturers of chemical compounds and apparatus for their application claim that the chemicals recommended by them do not injure the metal parts of furnaces and stoves. No authentic data have been available either to substantiate or refute these claims. Some analyses of treated coals have been made which show that the chemicals added are not sufficient in amount to materially affect the percentage of ash. Some experiments which have been reported indicate that the combustion of the coal is little affected by the treatment.

The chemical treatment of coal has become well established. There is every reason to believe that the sale of treated coal will continue to increase. The pertinent question then is, "What attitude shall the weights and measures official take toward the sale of chemically treated coal?" At least two associations of weights and measures officials have already gone on record in answer to this question. The Sixteenth Annual Conference of Weights and Measure Officials of the State of Michigan, in Detroit, June 25 to 29, 1929, passed a resolution to the effect that- 
it is its opinion that the so-called calcium chloride method of treating coal to make it dustless is not objectionable from a weights and measures standpoint, when by this process the weight of the coal is not increased by more than 30 pounds per ton, and when, in addition, the coal so treated is described on the delivery ticket and billed to the consumer as "chemically treated" coal.

At its conference in Indianapolis in June, 1929, the Indiana Association of Weights and Measures Officials adopted the following resolution:

Resolved, That the term "chemically treated" be hereafter applied to coal that has been treated in order to allay the dust usually attendant in the delivery of coal; further, that since in the chemical treatment there is of necessity a certain amount of moisture added, that it be the consensus of opinion of the weights and measures inspectors assembled that 2,000 pounds shall constitute a ton, just the same as though no treatment had been added, providing that advertising and quotations shall specify "chemically' treated" coal.

The attitude indicated in these resolutions seems fair and reasonable. Several factors which can not be controlled make deductions of weight for added moisture impracticable. Coal treated at the mine normally contains less moisture than coal treated in the yard. The average difference has been estimated at about 10 pounds per ton. Generally more moisture will be present in coal treated after loading into the delivery truck than when treated at the time of unloading into the yard bin. The percentage of moisture will also vary with the varieties of coal treated, as well as with the size of the coal lumps or particles. Precedent is not lacking for the sale of treated coal as such without taking into account the moisture content. In many lines of food manufacture natural products are slightly modified, but sold under the name of the product with a qualifying word or phrase.

Dealer and coal consumer are both protected if coal which has not been fraudulently manipulated is sold under terms which both understand. Interests of both dealer and coal consumer are safeguarded when chemically treated coal is sold by avoirdupois weight without deductions for moisture added through the treating process, provided, first, that the moisture added is kept within the limits necessary to properly distribute the chemical; second, that the coal is true to variety and grade; and, third, that the coal is advertised and sold as " chemically treated" coal.

\section{THE RETAIL GROCER}

By Henry Loemann, representing the National Association of Retail Grocers

Mr. Chairman and members of this conference, on behalf of the National Association of Retail Grocers, whom I have the honor to represent, I wish to thank you, Mr. Chairman, for your kind invitation to take part in this conference. Our national association always welcomes all such invitations from any of the Government agencies and our affiliated local associations are ever willing to cooperate with their commissioners, as we believe we retail grocers should be given an opportunity to present our side on all matters affecting the grocery and food business. We are firmly convinced that the greatest amount of good will accrue from such conferences between the Federal, State, and local agencies, and all trade bodies, to eliminate abuses or unfair trade practices by mutual agreements rather than by process of law. 
Mr. Janssen, our national secretary, suggested to me that I speak on the relation between the weights and measures department and the grocers. This is indeed a very delicate subject, but as a national association we are continually cautioning our local associations to meet with their weights and measures commissioners, invite them to their meetings and have round-table discussions on how best to serve the consuming public so that when they make their purchases they are assured of getting 16 ounces to the pound, or the correct measure when commodities are sold by the quart, peck, or bushel.

Our association does not tolerate any member who is not square with his customers in giving them honest weight or measure, or who employs other unfair or questionable methods in his business. We firmly believe that any grocer who uses such methods usually does not last long in business, as the modern housewife has scales in her kitchen and she will soon discontinue dealing with any merchant whom she detects giving her short weight or measure. As secretary of the Brooklyn Retail Grocers' Association, I do not recall ever hearing of any of our 750 members being in trouble with our local bureau of weights and measures in my 30 years' membership, because we will not tolerate any such practices.

At present we hear a great deal of propaganda about short weighting the public. Much of it is from promotors, and I do not think you will find any reputable grocers, large or small, who will stoop to such practices. I am assured if the weights and measures officials will enforce the law and make rigid inspections in every city and State and prosecute any merchant who willfully gives short weight or measure to the public, we will in a short time rid the country of this practice. Our national, State, and local associations will cooperate in every manner to bring this about.

The next subject I wish to speak about is the irregular or diversified packing of farm products. There is a large amount of unnecessary waste in packing and handling these products that could and should be eliminated. Retail grocers feel that you men should give this matter serious thought and strict study. As you know, at the present date fresh fruits and vegetables can be bought all the year round, being shipped from every State in the Union and packed in all kinds of containers.

The modern method of selling vegetables and fruit is either by the pound or by numerical count, which you will agree with me is the most simplified, accurate, and economical way of handling them. Then why not have the farmers, commission men, and wholesalers do the same to the grocers or retail fruit men? Knowing that selling fresh fruit and vegetables by weight or numerical count is the most efficient and accurate way, we feel that we should be permitted to buy these products in the same way. At present in the markets we buy some articles by weight, others by measure, and still others by container, and must guess at the weight. This makes it necessary for each retailer to weigh each container when it arrives at his store in order to find out how many pounds he bought. This causes confusion, as very often he has not sufficient time and must guess at the amount of contents.

We feel a good many articles could easily be packed in container's by the producers and sold by weight, such as potatoes, onions, turnips, carrots, etc. These articles adapt themselves very readily 
to shipping in sacks, preferably in 100-pound units. Beans, peas, etc., could be packed in bushel hampers with the weight of contents marked on hamper. and for the small grocer or fruit dealer in smaller units of 10 and 20 pounds. Bunched vegetables, such as carrots, beets, radishes, etc., should be sold by numerical count and packed in crates or boxes in lots of 25,50 , or 100 . Lettuce of all kinds should be sold by numerical count and should be packed in crates or boxes. The New York State standard crate for lettuce is to be recommended as the ideal crate for shipping lettuce. Lettuce shipped from Southern States, such as Florida, Louisiana, and Texas, is usually sent in baskets, and comes to us in the New York market in 48-quart baskets. This means nothing to the retail dealer, as he sells them by the head; consequently, he has to count the heads in each basket in order to arrive at the cost per head. If we look at the economical side of the question, let me say this is a very poor way of shipping lettuce, as the percentage of broken and decayed heads is very large and the receivers and grocers will not accept them, which brings heavy losses to the doors of the farmers and shippers. In the New York standard lettuce crate this is almost entirely eliminated.

After studying the 1928 container act, you will find that this act only applies to certain types of baskets; it does not apply to other containers, such as barrels, bags, etc., and even permits the use of other baskets if made in a different way than the baskets mentioned in this law, or if made from other material. It also makes it optional for maker, producer, or shipper to mark net contents on container, which should be mandatory.

Another instance is the California law, which permits other than the standardized apple box, and other sizes of grape lugs, besides the standardized size, if conspicuously marked "Irregular." This act does not make allowance for natural shrinkage; it should do so, and the shrinkage can be worked out by actual test in a very simple manner. I will try and point out to you how I think this can be arrived at. As soon as a container is packed with any of these farm products mark on the container the hour and the day the packing took place, then submit the full container to the most severe shipping test for a given period of time. Then measure or weigh the contents at the expiration of this period, and you will be enabled to find the amount of shrinkage per hour or day. These tests can be made for 24,48 , or 72 hours or more, according to the distance of shipment.

As an example, if products should be sold by weight, how simply and easily the allowance for shrinkage could be brought about, and the matter of adjustment of loss by spoilage be computed. Take, for instance, a basket of string beans: Net weight at time of packing, 35 pounds; allowance for shrinkage in 48 hours, 3 pounds; weight at time of arrival, 32 pounds.

The grocers feel the allowance should be made at the point of shipment, where the cost is lowest. To insure proper identification the name of the shipper and his address should be stamped on the container. This will facilitate the identification of the shipper, and the Federal bureau, if it found out that this shipper was in the habit of packing slack or not marking his weights properly, could take action against him. The effect of this action would be noticeable in all shipments. 
I found out yesterday that we had no effective weights and measures laws in a great many places. I really think that every State should have a weights and measures law, and our association would be very glad to take it up with you and try to get a weights and measures law wherever one is needed. We believe this work should be pushed, and we will get behind it. I guarantee the consumer will help put the law over in a very short time.

I am now going to come down and talk on a very delicate subject, and that is the sale of bread in standard-weight loaves. This is required in Indiana and other States. It is a grave injustice, not only to the baker, but to the consuming public, including the housewife, and I will try to demonstrate why this is so. In these States the weight of the bread is required to be 1 pound, $11 / 2$ pounds, or multiples of a pound. The price of bread is governed by the cost of flour and other ingredients used and the labor, and the baker and retailer should have a profit. In each community there is usually a certain set price for bread. When the bakers pay a certain price for the flour the consumer must meet that cost. If the cost of the flour rises, the baker can keep the local price of the bread constant but make the loaves slightly smaller. If he did not do that he, perhaps, would have to raise the price of bread to an odd cent. This rise in price will affect the retail grocer. Now, in New York City the standard price of bread has been 12 cents for three or four years, but we have no mandatory weight law. The loaf may weigh 20 ounces at one time, 22 ounces at another. We hare no trouble with that. However, if it were made mandatory to bake a loaf of a certain weight, and flour went up, the baker's price would go up and the retailer would have to raise his price, and you would hare confusion. If on the contrary the baker did not raise the price he could not put the same quality of ingredients into the loaf. In the absence of a mandatory standard-weight loaf the baker could make the weight accordingly and give the consumer the right amount.

Our National Association of Retail Grocers and its affiliated local and State associations will be pleased to hear from you men in conference here how we can cooperate with you to bring about more adequate provisions for the right kind of service, and a more rigid inspection, because we feel that most cities are woefully lacking in adequate weights and measures inspection. Gentlemen, I thank you.

\section{DISCUSSION OF ABOVE PAPER}

Mr. Rogers. Mr. Lohmann, I would like to ask a question. You ask cooperation. Cooperation is a fine thing for the weights and measures men. But can this be a one-sided proposition? TVe hare no record in the State of New Jersey where we were asked to attend a convention or meeting of either the retail or the wholesale grocers; and yet we always invite those groups when we hold our meetings.

Mr. Lommans. I tell you what I will do. I will get in touch with your lecal secretary, and I think you will be invited to the next State meeting.

Mr. Rogers. I think if you will make that a general practice and get in touch with the sealers generally you will find those men will be glad to attend your meetings.

(At this point, at $1 \mathrm{o}^{\prime}$ clock $\mathrm{p}$. m., the conference took a recess until 2 o'clock p. m.) 


\section{FOURTH SESSION (AFTERNOON OF WEDNESDAY, JUNE 4, 1930)}

TOUR OF THE LABORATORIES OF THE BUREAU OF STANDARDS

(The afternoon session of the conference consisted of a visit to the various laboratories of the Bureau of Standards, particular attention being devoted to the division of weights and measures. In order to make the trip of maximum interest and helpfulness, the delegates and guests of the conference were divided into small groups, each group being in charge of a member of the staff of the bureau.) 


\section{FIFTH SESSION (MNORNING OF THURSDAY, JUNE 5,1930 )}

The conference reassembled at 10.07 o'clock a. m. at the Bureau of Standards, Francis Meredith, first vice president, in the chair.

\section{THE INSPECTION OF WEIGHTS AND MEASURES IN PHARIMACIES}

By George F. Austis, Jr., Assistant Supervisor, Bureau of Weights and Measures, Detroit, Mich.

Mr. Chairman and members of the conference and guests, the subject upon which I am going to talk, as you can see by the program, has to do with the inspection of prescription scales and glass graduates. Perhaps a better title to the paper would be "Life in the Balance." It would give it a more serious complex, which I think would bring about better results.

The life of a weights and measures official could mell be compared to a huge nightmare, wherein the entire stage is occupied with weighing and measuring devices ranging from those capable of weighing and measuring a beam of light to those capable of weighing and measuring the world itself.

As tasks go, the work of a weights and measures official is a mighty one, and with its many phases, each one important in itself, we find it very difficult at times to decide just what phase of the work has to suffer most through our inattention. As a result, it is alarming to note that the superrision of prescription balances and glass graduates used in pharmacies for compounding prescriptions, in many instances containing deadly drugs, is that phase of our work which is generally the most neglected. Just why this part of our work is so commonly neglected may be explained in many ways, but that there is a vital necessity for it will be pointed out in reports to follow.

When I received this program assignment, together with information to the effect that this particular subject had not been touched on for a long time, I became curious to know just how many years ago it had been given mention and what was said. So I immediately consulted the very splendidly arranged index which the Bureau of Standards just recently issued for the proceedings of each National Conference of Weights and Measures Otficials. To my surprise I found that 16 years have elapsed since the subject of prescription scales and glass graduates has occupied a place on the national conference programs. In the year 1914, on the occasion of the ninth annual conference, a paper was presented by F. P. Downing, who was then chief inspector of weights and measures in Wisconsin. To say the least, Mr. Downing's paper was a masterpiece; he not only presented his entire subject in a masterly and scientific manner but he succeeded in making it comprehensive and to the point. And so in compliment to Mrr. Downing and for your own personal aggran- 
dizement I urge you to scan this very fine report, which is to be found in the Report of the Ninth Annual Conference, on pages 39 to 52 , inclusive.

After reading Mr. Downing's paper myself I came to the conclusion that there was not very much left for anyone to say on the subject, except, perhaps, to report on the present-day conditions thereof. Simultaneously, however, I saw an urgent need for the resurrection of his paper and the injection of some inspiration and enthusiasm into many of our delegates for the purpose of stimulating their present feeble activities in this branch of our work, which is so very important to life itself.

What is life? Life in reality is a challenge to our physical strength from the time of our advent on earth until our death. A challenge to meet, endure, and overcome, if possible, the many trials and tribulations which our bodies are subjected to constantly, at times threatening our very existence. Part of that great challenge to life itself is a moral challenge to every living soul; it comes in the form of opportunities, and the one paramount opportunity which is always present, the one I choose to call your attention to, is that of safeguarding public health.

How many of us ever stop to consider what a glorious privilege it is to live, to know, to act, to listen, to behold; to walk upon the green earth; to look up at the blue summer sky; to see the sun sink slowly beyond the line of the horizon; to see the outstretched ocean; to look down yawning precipices or over distant sunny vales; to see the world spread out under one's feet like a mat? To do all this is but part of the joy of living; and so, you see, it is not difficult to realize how precious life really is, when one stops to consider what life really means.

In the city of Detroit we have been systematically testing all prescription scales, weights, and glass graduates used in the drug stores for the past seven year's, and the data listed herewith will serve to impress upon you the necessity for this type of work.

Prescription scales

\begin{tabular}{rr|r|r|r}
\hline \multicolumn{1}{c}{ Year } & Approved & Condemned & Confiscated \\
\hline 1923 & & & & \\
$1929 \ldots$ & & 50 & 3 \\
2 \\
\hline
\end{tabular}

As indicated, there were 73 per cent more prescription scales in use condemned in 1923 than in 1929.

In some cases we found that it required as much as 10 grains to move the beam from a position of equilibrium. 
Prescription weights

\begin{tabular}{r|r|r|r}
\hline Year & Approved & $\begin{array}{l}\text { Condemned } \\
\text { and confis- } \\
\text { cated }\end{array}$ \\
\hline $1923 \ldots$ & 11,000 & $\begin{array}{r}1,914 \\
12,000\end{array}$ \\
\hline $1,000+$ & $1,599-$ \\
\hline
\end{tabular}

As indicated, there were 508 per cent more prescription weights in use condemned in 1923 than in 1929.

The ranges of errors found in weights condemned and confiscated in 1923 were as follows:

5-grain weights found in error up to

10-grain weights found in error up to

1. 6

20 -grain weights found in elror up to

3. 1

30 -grain weights found in error up to

40-grain weights found in error up to

60-grain weights found in error up to

120-grain weights found in error up to

\begin{tabular}{|c|c|c|c|}
\hline & Year & Approved & $\begin{array}{l}\text { Condemned } \\
\text { and confis- } \\
\text { cated }\end{array}$ \\
\hline \multirow[t]{2}{*}{$\begin{array}{l}1923 \ldots \\
1929 \ldots\end{array}$} & & $\begin{array}{l}1,800 \\
2,000\end{array}$ & $\begin{array}{r}236 \\
78\end{array}$ \\
\hline & & $200+$ & $158-$ \\
\hline
\end{tabular}

As indicated, there were 203 per cent more glass graduates in use condemned in 1923 than in 1929.

The testing equipment used for the inspection of precision weighing and measuring devices in Detroit, consists of the following:

One small pocket balance.

One set apothecary weights.

One set metric weights.

One set grain weights.

One 16-ounce cylindrical glass graduate.

One 8-ounce cylindrical glass graduate.

This equipment is contained in two oak carrying cases which are very compact and easily carried.

The Michigan State department has just recently inaugurated a systematic supervision of prescription scales, weights, and glass graduates. Four men have been assigned to this work, and each one is furnished with a small leather handbag, containing the following equipment:

One small pocket balance.

One set apothecary weights.

One set metric weights.
One 4-ounce conical glass graduate. One 1-ounce conical glass graduate. 
In carrying on this great work, with its many phases and ramifications, it is quite obvious that a progressive type of personality is a valuable adjunct. In general, as everybody knows, there are three types of personalities, conservatives, average citizens, and progressives. The conservatives constantly resist change; the progressives just as naturally promote change; while the average citizens, by far the largest class, sometimes side with one group and sometimes with the other. Sometimes they are deceived by the rainbow promises of visionary radicals; sometimes they pay the penalty of listening too much to the forebodings of croaking fossils. Most times, however, they are sanely reasonable, open-minded but demanding to be "shown," so that to each extreme group they seem to be almost in league with the opposite faction. But in our line of endeavor, it is paramount that we be progressives, and as progressives we must necessarily be constituted with three great moral prerequisites, namely, restless dissatisfaction, constructive thinking, and enthusiastic determination.

Restless dissatisfaction, the first requirement, is the motive power in individual life, in national life, in commerce, in politics. Never let well enough alone. You were put here to work for yourself and for others, and especially for those to come after you. The man who is letting well enough alone and not trying to do better, might just as well be off the earth and give his place to some one who is willing to work. He does not deserve the noble work done here by the dissatisfied before he was born. We might all be traveling across country on a camel's back, like the Queen of Sheba, if we had been satisfied with camels and had not invented the 2-wheeled cart, the stage coach, the express train, the automobile, and the flying machine.

Constructive thinking, the second requirement, is the art of keeping your mind on the great and splendid things you would like to do; and then, as the days go gliding by, you will find yourself unconsciously seizing upon the opportunities for the fulfillment of your desire. To do constructive thinking, it is essential for one to be logical, rational, scientific, and philosophic.

Enthusiastic determination, the third requirement, is the fire that blazes in every successful life. It is the one necessary ingredient in the recipe for doing good work. It tramples over prejudice and opposition, spurns inaction, storms its object, and like an avalanche overwhelms and engulfs all obstacles. It is nothing more or less than faith in action.

Without restless dissatisfaction, without constructive thinking, without enthusiastic determination, man ceases to be progressive.

* * * * * * * * *

\section{DISCUSSION OF ABOVE PAPER}

Mr. Schwartz. Mr. Chairman, I have been interested in the testing of prescription scales, weights, and glass graduates since 1915 . I would like to ask Mr. Austin if he considers that a glass graduate can be accurately tested in the field and also how he works it-what fluid he uses.

Mr. Austin. We use the raw water. As to accuracy, we have supervisors who go out from time to time and check over the work 
of the men; in some instances they have brought graduates which have been tested in the field, into the laboratory and checked them and have found the previous calibration very accurate.

Mr. Schwartz. In New Jersey our experience has been that the testing of glass graduates in the field has been very unsatisfactory; the test is not as accurate as the one we get in the laboratory. Because of the adhesion of the liquid to the glassware the test is made rather difficult-it is practically an approximation.

Mr. Austin. We take care of it very nicely. We first wet the vessel we are about to test, very carefully. After water has been poured out of our test graduate it is quite easy to drain. Of course there is a minor possibility of an error of very little consequence.

But the check tests which we have made have proved conclusively that the field test is very satisfactory. I do not know why it could not be satisfactory in your State.

Mr. Schwartz. Well, of course, the making of our tests is a statewide proposition. You only have a city to cover. We cover the entire State and make a specialty of that branch of the work. Some of our work is practically similar to that which you do. But we feel there is great need for accuracy in this type of work, and in the testing of graduates we are not satisfied that we get nearly as accurate a test in the field as we get in the laboratory.

Mr. Sweeney. Mr. Chairman, may I ask Mr. Austin as to the policy they pursue in sealing weights and glass gracluates in the field. Are the weights stamped or is a certificate furnished?

Mr. Austin. We do not mark the weights. We feel that were we to stamp very fine weights, there would be the danger of making them inaccurate. Apparently it is not practical and so we have gone along without it.

I get your point that there is a risk that new weights might be secured or replacements made and that the certificate is only a guarantee that at the time we were there the weights were bona fide, but I do not think stamping would improve the situation at all. You might say this about scales in grocery stores. You can test and seal such scales, but 24 hours after you go there is no guarantee that the scales are accurate. The same thing would be true in scales used in drug stores. Does that cover your point?

Mr. Sweeney. It does. But what I was going to suggest is this: In Boston we designate the small weights by 1,2 , or 3 points, using a very fine sharp instrument to stamp them. We also furnish the manager of the store with a certificate describing the weights as to shape-whether oblong or square-and also designating the marks and number of points thereon. If there is a reinspection of that place, we demand that the certificate be shown to us-of course, we have a duplicate copy of the record in the office. The sealer checks the certificate to see whether any new weights have been added. If the sealer checks the weights and finds some which do not correspond with the certificate, then he knows which weights have been added and he need test only the new weights.

Mr. Austin. I like that idea very well.

The Acting Chatrman. I might interject that this is the practice throughout the State of Massachusetts. 


\section{REPORT OF COMMITTEE ON SPECIFICATIONS AND TOLERANCES ON SPECIFICATIONS AND TOLERANCES FOR AUTOILATIC-INDI- CATING SCALES, PRESENTED BY F. S. HOLBROOK, CHAIRIMAN 4}

Mr. Chairman and gentlemen, your Committee on Specifications and Tolerances has prepared a code of specifications and tolerances for automatic-indicating scales. This subject has been under consideration for several years. It was included in the program last year, but on account of insufficient time the committee found it impossible to bring in a report at last year's conference. The necessity for specifications for automatic-indicating scales, however, was pointed out at that time in the following words:

I may say, however, that it is the thought of the committee that the conference does not have satisfactory specifications for automatic-indicating scales, or if there are satisfactory specifications they are so widely distributed throughout rarious codes that it requires considerable cross-referencing to determine just what the requirements are. For instance, when these codes were first established the spring scale was the most widely used automatic-indicating scale, and, therefore, the requirements as to graduations on dials, etc., were included under the heading "Spring Scales." Howerer, with the rapid advent of automatic-indicating scales of differing types, it seems that it would be more reasonable to have the specifications referring to graduations on diais, etc., assembled under the general heading "Automatic-Indicating Scales." As you know, we already hare tolerances for this class of machine.

That outlines what the committee has in mind and we may advise that we may find it possible to bring in next year a report along these lines, in which case you will have an opportunity to accept or reject the recommendations made.

As you know, in Handbook M85 of the Bureau of Standards, containing the codes of specifications and tolerances of this conference, we do have under the heading of "Large Capacity Automatic-Indicating Scales," definitions and tolerances, but no specifications. It is intended that the heading here proposed supersede that one and that the specifications be general ones, referring to all scales of this class, regardless of capacity.

In general, the requirements of this proposed code which is now being placed in your hands are by no means new ones, and it seems that we may depart from our ordinary procedure followed in the adoption of new codes, and that, therefore, this new code need not be tentatively adopted. It is therefore recommended for final adoption at this time to go into force and effect on July 1, 1931. In the meantime, of course, the specifications for the various classes under their respective headings remain in full force and effect. When this code finally goes into effect it will be advisable to delete from our present codes various specifications which duplicate the material contained in this report.

Underlined portions of specifications are intended to be nonretroactive when the code goes into effect.

Finally, your committee feels that this code is by no means complete and that doubtless from time to time it may be found desirable to add specifications to this heading. Your committee during the coming year will be very pleased, indeed, to receive suggestions from anyone as to requirements which it is felt should be included and

4 The specifications and tolerances for automatic-indicating scales, as adopted by the conference, appear in the appendix, beginning on p. 150 . 
will give any such suggestions very careful consideration. Your committee does feel, however, that this code constitutes a good beginning in this important field.

Respectfully submitted.
(Signed)
F. S. HolBroor, Chairman.
A. W. SchwarTz,
Charles M. Fuller,
I. L. Miller,
Committee on Specifications and Tolerances.

DISCUSSION OF ABOVE REPORT

Mr. HоLвRоок. The suggested provisions of the code recommended, and which has been placed in your hands, will now be read, as follows:

DEFINITION.-An automatic-indicating scale is a scale in which is embodied or to which is attached a self-acting mechanism, the capacity of which may be equal to or less than the total capacity of the scale, through the agency of which the indicated or recorded weights of variable loads may be obtained. This definition is not to be construed to include scales which automatically weigh out commodities in predetermined drafts, such as automatic grain hopper scales, packaging scales, etc. Automatic-indicating scales may be of any one of the following types as classified and defined in these codes of specifications and tolerances: Platform scales (including counter platform scales), counter scales, spring scales, straight-face spring scales, and computing scales. Wach automatic-indicating scale shall be subject to the following specifications and to those given under the heading "Scales-General Specifications"; anrl. in addition, each scale falling within the definition of any of the classes mentioned above shall be subject to the specifications for such class except in so far as they may be modified by the specifications herein.

SpEcifications.-1. The weight dial or reading face, or the indicator, whichever is designed as the stationary element, shall be securely fixed in position; the moving element of the combination shall be securely attached to its operating mechanism: Provided, however, That this specification shall not be construed to probibit the employment of a movable auxiliary dial or reading face or a morable auxiliary indicator designed to be rotated or mored in reference to a fixed dial or reading face or a fixed indicator, respectively, for the purpose of "balancing out" tare weights.

This specification is to supersede specification No. 1, under the heading "Spring Scales," reading as follows:

1. Reading faces shall be permanently fixed in position.

The specification is amplified properly to corer the moving and stationary elements of the combination. When the specification was first written only a movable pointer or indicator was considered, but now we have, as you know, a large class of scales in which the reading face or dial is the movable element and the indicator is fixed in position.

The proviso refers to scales in which there is incorporated a device for determining tare. These scales are of various kinds; usually an auxiliary indicator or an auxiliary reading face is provided for the purpose of balancing out the tare of containers which are being filled. These scales are designed to indicate at one and the same time the gross weight and the net weight of commodities placed upon the platform.

The Acting Chatrman. In view of the fact that the report of the committee is in the nature of a progress report and that the entire 
subject is one that should be under observation and consideration, during and until the next conference, the Chair considers that it might conserve time if we do not adopt each specification individually but merely make observations, if there happen to be serious objections to some certain specifications. I think that after all of the specifications have been read we might consider the adoption of the report as a whole.

\section{Mr. Holbrook (reading) :}

2. All weight graduations on the dial or reading face shall be clear and distinct and in no case shall their width be less than 0.008 inch nor more than the width of the clear interval between the graduations. Corresponding graduations shall be equal in width. Main graduations shall not be more than 50 per cent wider than subordinate graduations.

This specification is to supersede specification No. 2 under the heading "Spring Scales," reading as follows:

2. All graduations shall be clear and distinct and equally spaced and in no case shall their width be less than 0.008 inch.

The requirement for equal spaces between graduations has been eliminated, inasmuch as other scales, in addition to spring scales, are included within the purview of the provision. You will note, also, that some new material has been added.

3. There shall be a clear interval between the weight graduations on the dial or reading face and this interval shall in no case be less than 0.04 inch. This interval is to be measured between the adjacent edges of successive graduations representing the smallest subdivision on the dial or reading face, and along the line of travel of the index of the indicator and shall be maintained whether or not the graduations are "staggered" or arranged alternately; that is, when the graduations are staggered the interval shall be construed to be the space from one graduation to the next consecutive graduation extended, if necessary, to intersect the line of measurement. When the graduations are not parallel the interval shall be construed to be the widest separation of the graduations which is included within the travel of the index of the indicator.

That specification is to supersede specification No. 3 under the heading "Spring Scales," which now reads as follows:

3. The clear interval between the graduations shall not be less than 0.04 inch.

You will note that the basic requirement is identical with the old basic requirement, but an interpretation of the manner of measurement has been included. Especially, if staggered graduations are employed, it is provided that the clear interval shall, nevertheless, be maintained.

4. The value of the minimum graduation on the dial or reading face shall be construed to be the smallest weight value represented by the travel of the indicator from the center of any graduation to the center of the next succeeding graduation.

This specification is new material. The term " minimum graduation" has been used in the specifications, and it is felt by the committee that this term should be defined. The language suggested is considered to be a reasonable interpretation of that term.

5. An automatic-indicating scale shall have a definite and clear zero graduation and shall be susceptible of giving an indication back of the zero graduation sufficient clearly to disclose an out-of-balance condition. These conditions shall be fulfilled whether the entire dial or reading face is graduated or the graduations commence at a fixed load. 
That specification is to supersede specification No. 5 under the heading "Spring Scales," reading as follows:

5. A spring scale shall have a definite and clear zero graduation and there shall be no stop to prevent the indicator from going beyond the zero graduation. These conditions shall be fulfilled whether the entire face is graduated or the graduations commence at a fixed load.

The specification has been reworded to accommodate scales having either a movable indicator and a fixed reading face or dial or a movable dial or reading face and a fixed indicator, as was the case in specification No. 1.

The further requirement of the specification is identical with the old requirement in the opinion of the committee.

6. All weight indicators shall be so designed and constructed that the indications are definite and may be read with precision.

This is to supersede specification No. 7 under the heading "Spring Scales," and is practically identical with the present specification.

7. All weight indicators shall reach to the graduations; or if the construction is such that the indicator and the dial or reading face are in the same plane then there shall not be a separation of the ends of the graduations and the end of the indicator, of more than 0.04 inch, this distance to be measured along the line of the graduations.

This specification is to supersede specification No. 6 under the heading "Spring Scales," and is practically identical with it.

8. When a weight indicator extends along the entire length of a graduation then all that portion of the indicator which may be brought into coincidence with the graduation shall be the same width throughout.

This specification is new and is designed to obtain a proper cooperation between the indicator and the graduations on the reading face or dial, so that the weight may be properly, accurately, and readily read.

9. The clearance between the index of the indicator and the dial or reading face shall not exceed 0.06 inch in the case of all automatic-indicating scales except spring scales not equipped with a device intended to compensate for changes in the elasticity of the springs due to temperature effects; in this latter class of scales this clearance shall not exceed 0.12 inch. Provided, howerer, That this shall not be construed to prohibit the employment of an additional indicator at a greater distance from the dial or reading face, designed and constructed so as to facilitate the correct positioning of the eye of the observer properly to read the indications of the scale and reduce parallax, when such additional indicator is clearly differentiated from the weignt indicator so that it will not be mistaken therefor.

This specification is to supersede specification No. 8, under the heading "Spring Scales," reading in part as follows:

The distance between the indicator and the reading face shall not exceed 0.12 inch.

and which contains also the proviso contained in this specification. It also is partially to supersede specification No. 5, under the heading "Computing Scales," which reads in part as follows:

The distance between the chart and the weight and the value indicators shall in no case exceed 0.06 inch.

It will be noted that the present requirement is that computing scales have a clearance between the indicator and the chart of not more than 0.06 inch, and that spring scales other than spring-computing scales, and all other automatic-indicating scales, have a clear- 
ance between the indicator and the reading face or dial of 0.12 inch.

Now the figures of 0.06 inch and 0.12 inch have been retained, but the classification of the scales to which these clearances apply has been modified to some extent as will be noted from the present wording suggested. It is believed by the committee that this classification is a better and a more logical classification than that which was formerly employed in the two specifications which $I$ have read.

10. When tests are being made with both increasing and decreasing loads on any automatic-indicating scale, the indications on all increasing loads shall be within the normal tolerances provided, and also at any stage of the test the range between corresponding observations for increasing and decreasing loads shall not be greater than the sum of the tolerances in excess and in deficiency for the load in question.

This specification is at present contained under the heading "Scales-General Specifications," but it is specified that it is to be limited to apply to automatic-indicating scales; therefore, it seems apparent that the specification should be included here and that erentually the requirement should be deleted in its present position. There has been no change in the requirements of the specification.

11. An automatic-indicating scale shall be so designed and constructed that the element supplying the counterforce, such as the spring, the pendulum, etc., is securely held in adjustment and this element shall not be adjustable from the outside of the scale; that is, a partial disassembling of the scale mechanism or of the housing shall be required to reach any adjustable parts provided.

This is to supersede specification No. 11 under the heading "Spring Scales," which reads as follows:

No device to alter the working or effective length of the spring shall be vlaced on the outside of a spring scale.

You will note that the old language has been amplified not only to include all counterforce elements, in addition to springs, but also to require that the counterforce element be securely held in adjustment. In addition, it contains an interpretation of what is meant by adjustment from the outside of the scale.

Tolmances.-Except on the special tests described above, the tolerances to be allowed on any automatic-indicating scale shall be the tolerances allowed on the class to which the scale under test belongs; these will be found under the specific heading embracing such class.

You will note that there is no change in the tolerance provisions. Under the method of procedure proposed to be adopted, the tolerances now included under the heading "Large-Capacity AutomaticIndicating Scales" will be transferred to the heading "Platform Scales" and will be properly amalgamated with the tolerances already contained under that heading.

That concludes the report of the committee. As has been stated, that report is recommended for final adoption at this time, with the proviso that the requirements do not go into force and effect until July 1, 1931. It has further been suggested that, when these specifications go into force and effect, the other codes of specifications be amended in order to prevent duplication between the new and the old codes.

Mr. Sweeney. Mr. President, I move the adoption of the committee report.

Mr. Framerty. I second the motion. 
The Acting Chamrax. It has been moved and seconded that the report of the Committee on Spécifications and Tolerances on Specifications and Tolerances for Automatic-Indicating Scales be accepted, and the recommendations adopted. Are you ready for the question?

Mr. Maroner. May I suggest to the committee that there is no specification offered for the width of the indicators that are used in conjunction with the various dials? May I offer the suggestion that the width of the pointer be restricted so that the end of that pointer shall not be greater in width than the width of the graduations on the dial? I offer this as a suggestion without going into detail on it. We all know that some pointers are unsatisfactory in this respect.

Mr. Holbrook. I think that is a rery good suggestion. As a matter of fact, the committee had under consideration a specification along that very line; but before proposing a mandatory specification they desired to make a general study of the entire question of indicators in combination with graduations. The main complication is that continuous indicators on computing scales are employed to cooperate not only with weight graduations, but also with value graduations. I can assure Mr. Maroney the committee will hare something to propose on this question at the next conference. It would hare been proposed at this conference, but the time available to obtain the required information was found to be too short and, therefore, after considerable debate upon a specification which reached the rough-draft form, it was deferred for future action.

Mr. Maroney. I thank you.

Mr. Briggs. Mr. Holbrook, in the specifications dealing with the dial graduations and other details, is there likely to be any confusion in interpreting these specifications in reference to an automatic indicating device, where optical means are employed-where the projected image of an indicator and scale may be used for reading?

Mr. Holbrook. The device to which you refer was in the minds of the committee, as were all automatic-indicating scales with which we were familiar. At one time it was considered that a special specification might be included to cover this, due to the fact that the indicator and the reading face or dial in this case would be the shadow which is read on a ground glass face-it would not be the actual scale which projects the image. However, it seemed to the committee to be so obvious that the shadow scale and indicator which were read were the scale and indicator referred to in the specifications that it was not considered necessary especially to point that fact out in the specifications.

Mr. Briggs. You have covered the ground and considered that in preparing the specifications?

Mr. HolbrooK. We consider the specifications are applicable to the machine which you mention.

Mr. Briggs. Proposed specification No. 9 reads, in part, as follows:

The clearance between the index of the indicator and the dial or reading face shall not exceed 0.06 inch in the case of all automatic-indicating scales except spring scales not equipped with a device intended to compensate for changes in the elasticity of the springs due to temperature effects;

There seems to be no reference to size of dial. It occurs to me that there is one type of scale which would be required to conform to this 
clearance which might have difficulty, and that is these pendulum scales which have dials 3 or 4 feet in diameter. It seems that the matter of size of dial might be giren some consideration in a provision of this kind. Manifestly, if you hare a dial 4 feet across it would be much more difficult to maintain the necessary clearance for the satisfactory operation of the mechanism than when you have a small dial.

Mr. Hогввоок. That is undoubtedly true, but the committee naturally desires to maintain the smaller clearance of 0.06 inch in all cases where it is possible to do so, in order to reduce the parallax and obtain as accurate a reading as may be from the combination. It $\pi$ is considered in relation to the class of scales that you mention that the machining of the parts is so carefully clone, and they are arranged so truly within the scale, that the manufacturers would be able to live up to that requirement. If any difficulty is apprehended by the manufacturers the committee would be very glad to listen to their statements in that connection.

Mr. Briggs. In specification No. 11, a provision is introduced which, on careful reading and study, relates apparently to the adjustment of a device, and does not relate to the balancing of the scale.

Mr. Holbrook. This specification is not considered to relate to the ordinary balancing means, as that which changes the relation of the rack and pinion, for instance.

Mr. Briggs. You have in mind such changes as the effective length of the spring?

Mr. Holbrook. Yes.

Mr. Briggs. It occurred to me in reading it, howerer, that in the minds of some it could be very easily confused with the balancing arrangement, or the device used to set your indicator at zero. No sooner had that thought occurred to me than some one in this neighborhood commented on the making of the zero adjustment in such a case. Would it not be desirable to introduce a sentence making it clear that it is not intended to apply to the adjustment of the zero?

Mr. Holbrook. If the specification is likely to be misleading, I think it would be well to add a sentence indicating in effect that the requirement is not intended to apply to the ordinary balancing arrangement, commonly employed, and if the conference is willing, the committee would be very glad to frame a sentence along those lines and add it to the specification.

Mr. Briggs. Just one more point I have in mind, possibly a minor one. I find no reference to the word "symmetry" or "symmetrical" as a requirement for pointers or indicators.

Mr. Sweeney. You will find that in specifications Nos. 7 and 8.

Mr. Briggs. The point I have in mind is that where the indicators are not symmetrical there are differences in personal viewpoints as to whether the observer is reading precisely on the indications. It would apply whether the pointer extended the full length of the graduation or not.

Mr. Holвrooк. I think, Mr. Briggs, that is exactly the kind of suggestion the committee asked to be made, and the committee might very well give the question of the symmetry of the indicators consideration during the coming year. 
Mr. Harrison. I understand from specification No. 2 that you contemplate that certain graduations may be wider than other graduations. Reference is made to the fact that the graduations may not be wider than the clear interval between the graduations. Is it contemplated by the committee that the clear interval between graduations referred to should be maintained between the wider graduations and those adjacent to it, or is it sufficient to have the required clear interval between the graduations which are not so wide?

Mr. HoLвRоок. It would be my interpretation that no graduation might be wider than the clear interval between that graduation and the graduations adjacent to it. If it is desired to make the width of the graduation equal to the width of the clear interval between the graduations, in that case all of the graduations should be of equal width. I think it would be very unfortunate at any point on the dial to have any graduation which is wider than the clear interval between it and the adjacent graduation.

The Acting Chammax. With the suggested changes which the committee will deal with in accordance with the expressed understanding, ${ }^{5}$ we are now ready for the question on the adoption of the specifications as a whole.

(It was moved and seconded that the report of the committee be adopted as recommended, the question was taken, and the motion was agreed to.)

\section{THE SUPPRESSION OF FRAUDULENT PRACTICES}

By J. M. VANDersuce, District Supervisor, Bureau of Weights and Measures, City and County of Philadelphia, Pa.

Mr. President, delegates, and friends, the bureau of weights and measures of Philadelphia is composed of seven subdivisions, each one under the direction of a district supervisor, as follows: (1) Scales, weights, and measures; (2) commodities; (3) coal inspections; (4) purchasing of commodities; (5) inspection of drug scales; (6) gasoline and oil; and (7) milk bottles.

In Philadelphia 90 per cent of our prosecutions are based upon evidence secured by our own inspectors in making purchases of commodities, while the balance of our prosecutions result from investigations where we find dealers manipulating scales in various ways. Our method of investigation by making purchases of commodities is as follows:

In Italian, Jewish, or colored sections we engage by the day a woman of each respective nationality to do the buying; after the purchase is made she is met outside of the store by our inspectors, who accompany her back into the store. The goods are reweighed on the scales over which they were sold. If the weight is correct, usually the merchant is glad to refund the purchase price, thus enabling us to make many purchases without too great an outlay of money.

If the purchase is short in weight, the commodity is retained by our inspectors, we swear out a warrant, and the defendants are

5 In accordance with this understanding the following adition was made at the end of specification No. 11, as read: "(This specification does not refer to the means commonly provided for adjusting the zero balance condition of a scale.)" 
brought before the court. If the goods are perishable, they are given to some public institution as soon as possible.

On private complaints the same procedure is followed, when the buyer will make an affidavit, but sometimes it is very difficult to get these private complainants to appear. A recent example of this follows: On Saturday morning one of our inspectors noticed through the window of a certain store a woman buying a ham. He also noticed the butcher putting his hand under the scale and pulling it down. Our inspector stopped the woman outside the store and told her about it. The ham was brought into our bureau, and upon being reweighed it was found to be $11 / 2$ pounds short on a purchase of 6 pounds. This woman swore to the affidavit and the date for the hearing was set. On the morning of the hearing we called at this woman's home to take her to the court, but we were informed by her daughter that she was ill and unable to appear. We realized that she had been influenced to stay away. The butcher appeared at the hearing, and, of course, our case failed, no prosecutor being present.

The butcher told us the whole story. It appears that three days following the purchase this same woman called on the butcher to make another purchase, cautioning him to keep his hands off the scale and warning him that he was going to be arrested. The butcher told her he would take care of her if she would not appear at the hearing; she promised to stay away. All she got out of this was two small pieces of meat. Her husband earned $\$ 18$ a week, and they had seven children.

So you will appreciate how difficult it is to get convictions. Some people make a practice of buying from these butchers, taking a chance of getting short weight; if they detect short weight, they demand money from the butcher, knowing that if he is arrested it will cost him much more. From our experience we have found that dealers in meats and poultry are the most flagrant offenders against the weights and measures laws and the most persistent in selling short weight. A number of dealers have been prosecuted and fined a second and third time.

Before the advent of the modern scale 80 per cent of the weights were incorrect. The worst weight ever confiscated by this office was a 4 -pound weight that weighed only $21 / 2$ pounds. The chain stores operated by the large companies cooperate with us to the fullest extent. It is with the small dealer that we have the most trouble. When our bureau was organized 16 years ago we found that 90 per cent of the milk bottles in use would not hold their legal capacity, but after correcting this matter with the manufacturers we soon found the percentage of short milk bottles becoming smaller and smaller, and for several years past we have been unable to find an undercapacity milk bottle in Philadelphia. We have a special crew assigned to inspect drug-store scales and weights, who are particularly trained in that branch of our work and who devote their entire time to it. The situation on coal inspections in Philadelphia is very good; occasionally we find some dealer who attempts to sell short weight, very much to his regret.

Now, as to the gasoline and motor-oil proposition, I may say that we have about 9,000 gasoline pumps and many thousands of oil bottles 
to look after. We have 22 inspectors to cover an area of about 133 square miles. Again it is the little fellow we have to watch. Since last September we have ordered destroyed about 500 illegal oil bottles. We found the small dealer using so-called Mason fruit jars for oil bottles; these were improper, for, in the first place, the content was not blown in the bottle, and then again they did not hold a quart. We usually give the dealer his choice of breaking them up while we are present, or having them confiscated by us, which means prosecution. He usually breaks them.

When we receive a complaint from some one who thinks he has received short-measure gasoline, I call upon the complainant and get the exact location of the pump from which the purchase was made. I then call at the gasoline station and make a purchase of gasoline from that pump directly into the "dummy" tank of my car, which I will describe later. A short distance away we drain this gasoline out and measure it. If this amount is short, some time within one week afterwards a second purchase is made in the same manner. If the second purchase is also short, we leave the car some distance a way and return to the gasoline station on foot and test all pumps on the premises. This is about 10 minutes after the second purchase is made. The reason for allowing one day or more to elapse between purchases is to classify the seller as a persistent violator. If the pump from which the short purchase is made shows correct on the test, then the pump must have been manipulated on the sale. If the pump is short on test, then the sale was made from an inaccurate instrument. In either case a warrant is issued for the manager of the station. We have made many arrests for this violation and have secured 100 per cent convictions. Not one case has failed, nor has one case been appealed.

For the purpose of making test purchases I have a double tank on the back of my car. By the use of levers and a connecting pipe, this tank can be made into one complete running tank, or it can be separated into one-half running tank and one-half buying tank. We buy into the regular inlet of the tank. The other side has a "fake" gage cap which can be removed, thus giving me a separate inlet into each side of the tank if necessary.

I wish to say at this time I have this car outside and at the conclusion of this program, if anyone cares to have me do so, I will be glad to explain it and show them how we work it in Philadelphia.

The penalties in Pennsylvania are: For the first offense, $\$ 25$ and costs, that is, $\$ 4$; for the second offense, $\$ 50$ and costs, that is, $\$ 4$, and for each and every subsequent offense, a fine of not more than $\$ 100$. In default of the payment of any fine as aforesaid, the person convicted shall be sentenced to serve one day in jail for each dollar of the fine and costs. This has proved so effective that in the last year we have not been able to catch the same offender twice. The worst buy we ever made was $21 / 2$ gallons for 5 gallons, from a condemned pump.

One particular case I would like to cite before closing is as follows: We received a complaint that short measure was being given at a certain place from a certain pump. I made five purchases from this pump-every one was short, varying from 30 cubic inches to 80 cubic inches. After the last purchase the inspector and myself re- 
turned on foot and tested the nine pumps which we found on the premises; eight were correct; the one from which we bought short, showed short on test and, of course, we condemned it. We watched the place for two days to see if they continued to sell from the condemned pump. On the following day we attempted to make a purchase from this condemned pump, but the manager would not sell from it; instead he shifted us to the adjoining pump and we received short measure in the amount of 30 cubic inches from this pump. Needless to say, we swore out a warrant for his arrest, and he was fined $\$ 25$ and costs, that is, $\$ 4$.

\section{DISCUSSION OF ABOVE PAPER}

The Activg Chamrixax. Does anyone wish to ask any questions on this paper?

Mr. Crocketr. Mr. Chairman, I would like to ask what shortage is allowed.

Mr. Vandersice. Seven cubic inches in excess or deficiency.

Mr. Crocketr. Do you hold it to 7 cubic inches?

Mr. VANDERsLice. Yes.

Mr. Holbrook. Mr. Chairman, in connection with the statement of the gentleman from Philadelphia that he has a test car here, I am also advised that the division of weights and measures of the city of Baltimore have brought over their decoy car used for the purpose of making test purchases of gasoline, and this may be examined by those interested during the noon recess in front of this building. James T. Everett will be in charge and will show how it operates. Thus we will have the opportunity to examine two cars at the same time.

The Activg Champrax. This is a very interesting subject, and I have no doubt that many will enjoy the opportunity and privilege of examining these cars.

Mr. C. P. Sirıth. Mr. Chairman, I would like to ask the gentleman from Philadelphia what allowance he makes for the liquid that might adhere to the sides of the tank and the hose.

Mr. Vanderslice. We never prosecute for shortages of less than 30 cubic inches.

Mr. Austin. Mr. Chairman, Ralph Smith has asked me to give a description of our testing in Detroit; and if time permits, I would like to go ahead with that. In this connection I would like to ask the gentleman from Philadelphia a question: Do you buy this gas outright in Philadelphia?

Mr. Vanderslice. Oh, yes; we pay for it.

Mr. Austin. The ordinance of the city of Detroit specifies that short weight is illegal in the case of any commodities purchased, sold, or exhibited or offered for sale, and a person is subject to prosecution for offering for sale a commodity short in weight the same as though it were an outright purchase. This has this advantage, that we can make many purchases and return the commodities if found full weight or measure. It saves the handling of the commodity. I will go over some figures briefly before I point out our method of buying. 
The following results were obtained in a 7 -day drive with one "buy car" operating:

391 5-gallon purchases (1,955 gallons handled).

54 shortages, from 1 pint to 11/4 gallons.

13.8 per cent of the deliveries were short measure.

Total fines, $\$ 1,140$; average fine, $\$ 21$ (approximately).

In a 3-day drive conducted very recently with two "buy cars" operating the following results were found:

382 5-gallon purchases (1,910 gallons handled).

40 shortages, from 1 pint to 1 gallon.

10.5 per cent of the deliveries were short measure.

Total fines, $\$ 790$; average fine, $\$ 20$ (approximately).

In the case of the latter work we have made conservative estimates as to what losses will result to the purchasing public, of the city of Detroit, from shortages such as in the following:

Total shortage on 382 purchases_-_-_-_-_-_-_-_-_-_-_-_-_ounces_- 1, 36.5

Average shortage per sale, approximately

Approximate number of sales per day at each station

Total shortages per day, 245,000 ounces_-_-_-_gallons short per day

Steal per day $\$ 382.80$

Steal per month $11,484.00$

Steal per year

$137,808.00$

You can see the seriousness of this shortage of gas-it amounts to considerable when you get down to figures. In just a moment I will explain what a "buy car" is.

Now, we find that when we make a drive the word flashes about the city in the shake of a lamb's tail. We find that after we have been out operating our buy cars for two and one-half days, the number of shortages decreases. That shows that the element of advance notice must be eliminated and this is how we go about it to eliminate that.

Most of these drives we put on over the week-end. We start about 10 o'clock Saturday morning, and about the same time the last loads of gasoline are leaving the refineries for the last trip on Saturday. They return to the refineries about 1 or 2 o'clock in the afternoon. So shortly after we start out, the tank wagons are returning to the station, with the result that this means of communicaion is not possible. Telephones have been eliminated from all company stations, so news is not likely to spread in that manner. The main thing in a gas drive is to make as many stops as you can and in as short a time as possible. By the method which we have adopted, we make a gas purchase every eight minutes; when using the two buy cars we can make two every eight minutes, or one every four minutes.

The last drive described was a 3-day drive and we made 382 purchases covering almost one-fourth of the gasoline filling stations in the city in three days. Now, it will be interesting to point out how we were able to make three hundred and eighty-two 5-gallon buys in three days. We use in connection with one "buy car" two "follow-up" cars which carry the measuring equipment. As it takes about twice as long to check as it does to make the purchases, you can see that one buy car will keep two follow-up cars busy. The buy 
car comes in and makes a purchase at a station. Immediately after the delivery, the question is always asked of the operator as to the cost, so as to commit him to the fact that he understood what was asked for. For instance, if you have asked for 5 gallons of gas and he quotes you the price of 4, you know he has misunderstood you, but if he quotes the proper figure for 5 gallons there is no question about a misunderstanding. Just the moment delivery has been made to the buy car the follow-up car drives up and makes a test of the gas delivered; in the meantime the buy car is proceeding to the next station, where a purchase is made, and this time the second follow-up car makes the check; and so on.

In that way it is possible to make a stop every eight minutes with the buy car and if you are lucky enough to have two buy cars you can double the speed of the work.

Mr. Crocketr. Are these tests made right in the station?

Mr. Austin. These tests are made at various stations, but they are not made at every station along the street.

Mr. Crocketr. Do they make the measurement right at the station?

Mr. Austin. Yes; the measuring of gas is done right in front of the operator.

Mr. Maroner. Mr. President, may I ask Mr. Austin a question? You tell about the loss of gasoline, but say nothing of pumps that were in excess.

Mr. Austin. You do not find many.

Mr. Sweeney. What did you find?

Mr. Austin. We do not keep a record of it. I would simply say there are few overdeliveries as much as 7 or 8 cubic inches; sometimes you might get a half pint over.

Mr. Maroney. Then your figures are unfair when you quote the percentage of the total loss to the consumer, because if at one station one pump is over and one is under, the discrepancies tend to cancel each other, and there may be no net loss to the average consumer. If you neglect overdeliveries in your figures the total loss in your city is not what your figures show.

Mr. Austin. Surely.

Mr. Maroney. With a temperature above $90^{\circ}$, for instance, the expansion might make a considerable difference. Again, suppose the drainage of the hose is not perfect. In other words, suppose in draining a partial vacuum was created and you found the shortage was due to the fact that liquid was retained in the hose. Would that bring a prosecution?

Mr. Austix. We do not pay any attention to what may be left in the hose. There are cases where we found they made a practice of holding some part in the hose, afterwards pouring this back into storage; so any gas which is not actually delivered is not taken into account.

Mr. Maroner. Suppose a 7 -cubic-inch tolerance is allowed; would you prosecute a man on a shortage of 7 cubic inches in 5 gallons if you found 7 or 8 cubic inches had been retained undelivered in the hose-gas which he would have delivered to you had the hose drained properly?

Mr. AUstiv. All we take into consideration and the only thing in which we are interested is a shortage of 1 pint or over. 
Mr. Maroner. And if there is excessive heat in your town which expands the relief valve and it does not work as it should he is a violator of the law?

Mr. Austin. Yes; the seller is responsible for what is delivered.

Mr. VANDERSLICE. I would like to say, Mr. Chairman, that we use New Jersey tags when we make test purchases in Pennsylvania for the reason that all the stations are familiar with the Pennsylvania numbers that we use. I would like to ask Mr. Austin what kind of a tank he buys in.

Mr. Austin. Our tanks are designed with a funnel-shaped bottom and a pipe leading from the back of the car.

Mr. VANDERSLICE. If you are not going to buy for checking purposes, would you buy into the same tank?

Mr. Austin. No; we use a different tank for the fuel supply. But the original tank is the one used in the check purchases. We use several different makes of cars, and the tanks are in the original place but they are redesigned for this special purpose by pulling out the ends and putting in a false bottom so that it all drains to one point.

Mr. Vanderslice. I do not think that would go in Pennsylvania.

Mr. Austin. Well, it goes all right in my city.

Mr. Scrwartz. I want to say, Mr. Chairman, for Mr. Vanderslice's information, that we use Pennsylvania tags when we make check purchases in New Jersey.

THE ANNUAL REPORT OF THE OFFICIAL

DISCUSSION OF THE SCOPE AND PREPARATION OF THE REPORT

By H. S. JARRETT, Commissioner of Weights and Measures, State of West Virginia

Mr. Chairman and members of the conference, one can not help but note the wonderful progress that is being made in weights and measures administration throughout the various States. This is evidenced, of course, from the State reports and the excellent papers that have been submitted to this conference. In this paper that I am submitting to you to-day I have embodied some ideas that I have had as to future progress in the work, and I trust you will bear with me just a few minutes until I can dispose of this.

The compilation of annual or biennial reports of State, county, and municipal weights and measures officials composes an important part of the work of every department. Those charged with the duty of compiling these reports are required to delve into a mass of tabulated transactions of sealers and cull from the conglomeration of figures that portion which in their opinion is not essential. Then there is usually left a bare skeleton of the real information which should be disseminated. The compilers of the report are required to familiarize themselves with a whole year's activities of the sealers if they are arranging an annual report, and they naturally become acquainted with every detail entering into the work of the field force. But what other person or persons have such information? The individual officials know what has transpired during the period, yet when the report is printed and distributed, have they submitted statistics 
that will enlighten and interest the public and place the departments in a position where they receive the recognition due them?

When our reports are ready for submission to the proper authorities they are frequently in a form setting forth, principally in figures, data showing so many scales or other equipment tested, adjusted, condemned for repairs, or confiscated, leaving the reader without sufficient knowledge to pass favorable judgment on the work. The question that confronts us is: "Have we been submitting adequately definite, intelligible, and convincing reports to justify impartial opinions that our departments should be given encouragement through additional authority and enlarged appropriations to effectively carry on the work?"

It is not my purpose in this paper to constitute myself a board of censors or endeavor to pass judgment on those invested with the responsibility of preparing and submitting reports. I am guilty of the general practice of indiscriminately and hastily collecting and assembling a lot of figures and calling it an official report, when in fact I must admit it has a very slight semblance of being what a comprehensive document should be. Year after year we hear reports that legislatures or other tribunals decline to increase appropriations or else curtail the appropriations made in previous years. What is the reason for their action? Every weights and measures department is conscientiously doing effective work in an efficient manner. They are saving to the purchasing public thousands of dollars and at the same time protecting the honest merchant in his daily transactions. We have not failed in our duty as conservators of honest weights and measures, but we have been derelict in letting the public know what is actually transpiring within the departments. Far be it from me to shout our virtues and withhold our deficiencies, but we have been prone to enlarge upon numbers and neglect attention to more distinctive features.

While our reports may be sought by those directly interested in weights and measures, I contend that others should manifest a desire to acquaint themselves with our work. I am positive that if our reports were made more informative, more attractive, and more useful for reference, we would then gain prestige and advance with greater strides in the future than in the past. It is my candid opinion that our reports can be made so impressive they will leave within the minds of the reader a more wholesome and popular conception of the duties and responsibilities of a weights and measures official. To this end it is my desire to offer a few suggestions rather than continue pointing out our imperfections and discrepancies.

Our reports are incomplete in the first instance from the fact that we fail to analyze the data presented. For instance, we prepare, and find it no small task, a number of tables with the idea of setting forth just what the various sealers have found in testing scales and other devices. The daily reports of inspectors sent to the central office of the department are of such a nature that the chief may grasp in an instant the problems and difficulties confronting the sealer. If the sealer is seeking advice, that advice is readily given and the correspondence ends. When the annual report is prepared it discloses just another scale condemned for repairs, yet many letters and expressions of opinion may have passed between the oficials. 
I fully realize that it would be impracticable to analyze each transaction, but it would serve a beneficial end if 10 or 12 special occurrences were to be picked at random and analysis made for publication in the report. Such analysis would serve a twofold purpose. A digest of each case selected for comment would acquaint the public with situations where they would become observers at every weighing and measuring transaction in which they are involved. The public would be sold on the effectiveness of our work and the necessity for extension of our activities. Then, again, the report would serve as an instructive document in the hands of officials. They would know how certain problems were solved in a sister State and would be afforded aid in solving problems arising in their own State. We will have accomplished great results if we can create a closer relation between the public and the official.

It is my contention that numerical results should also be expressed in percentages and these results carried over for a certain number of years, that all may determine at a glance what progress, if any, is being made. A general scheme of arrangement or analysis from year to year would facilitate the work of having to delve into former reports to find what has been accomplished in the past years. The tabular forms would condense these data, yet present just the information we are compelled to seek when presenting our claims of advancement. All such items should be reported on concisely but fully, and all special activities made a part of the report. Future plans should be outlined briefly to include recommendations for amendments to present laws, increased operating funds necessary, new equipment essential for expansion, and other requirements peculiar to each department, setting forth explicitly why these recommendations should be favorably considered.

The frequent use of cuts with descriptive matter adds untold interest to any report. Their use would serve to far greater advantage than pages of technical analysis that leave the reader unenlightened. Example is the school of mankind and many will learn at no other. Example preaches to the eye and often leaves a deeper impress than volumes of counsel addressed to the ear. A lesson once thoroughly comprehended is indelible.

An inventory of our equipment should be included in the report to show the vast amount and varied articles necessary for use in our work.

Exceptional violations where court action has been found necessary could be so given in detail as to strengthen confidence in our veracity and confirmation in our exercise of authority.

Judicial opinions affecting some phase of our regulations, and amendments to statutes, should be given following the rendering of these decisions or legislative enactments.

A résumé of the more important topics considered at conferences should be briefly summarized.

I do not feel it would be amiss to create in this conference a committee, to be known as a committee on the compilation of State reports, whose duty it would be to work out a model form to be followed, if we so desire. I am sure we can enlist the services and advice of the Bureau of Standards on this question and I am certain the officials of the bureau would give to us the benefit of their experi- 
ence, together with suggestions and counsel in this matter the same as they have in so many other problems in which we have sought their guidance.

Usually our reports are compiled at the end of the fiscal year when wo have used up almost all of our appropriation and as we are compelled to keep within the specified allotment, we are required to reduce the material to a minimum. It would be well to estimate early in the year when appropriations become available just what will be required for our report and then govern ourselves accordingly.

The better the reports of our work, the more emphasis will then be placed on our needs, but if we continue to present unintelligible reports and conclude by urging that our recommendations be carried out, we have not convinced anyone of the necessity for the appropriations which we have recommended.

I feel our reports can be made to serve as a message, presenting our activities so forcibly that we will not have to stress our needs but those needs will be readily recognized. I feel positive that if we attach greater importance to the preparing of these reports the confidence of the public will be retained and we shall receive grateful acknowledgment as a reward for our efforts.

\section{GRAPHICAL PRESENTATION OF DATA}

\section{By Henry D. Hubbard, Bureau of Standards}

This century has seen an astonishing rise in the use of graphic methods. These translate into vivid diagrams the statistics which would otherwise be difficult to analyze and compare.

Weights and measures officials may well adopt methods so successful in other fields, notably in science where the use of graphs is universal. The clearness, force, and interest which graphs introduce improve the presentation of data and enliven the dull and neglected columns of Arabic numerals which we call statistics.

Without effort graphs give the eye and mind an instant grasp of magnitudes and their relations. Comparisons of quantities and numbers become automatic. Graphs speak the language of pure quantity. They may show the rise and fall of activities, their maxima and minima, and their averages. They are self-interpreting. In brief, the mind can begin its study of the data where such illuminating diagrams leave off, at a point far in advance of mere tabulation.

I have prepared a special series of graphs of interest to weights and measures officials. The literature of graphical methods is becoming very rich, and numerous books and articles can be commended for study of scope and method. In this talk, however, I shall sharply limit myself to a few types of graphs which might be useful in weights and measures records and reports.

Figure 1 shows for every year since 1915 the percentage of railroad track scales tested and found within tolerance. The time scale runs from left to right by years, the percentage scale runs from 0 to 100 upward at the left edge, and the resulting history curve gives a vivid impression of the advance in the accuracy of railroad track scales during the past 14 years.

A second kind of graph (fig. 2) might be called a "percentage analysis graph." Five varieties of weights and measures are studied. 


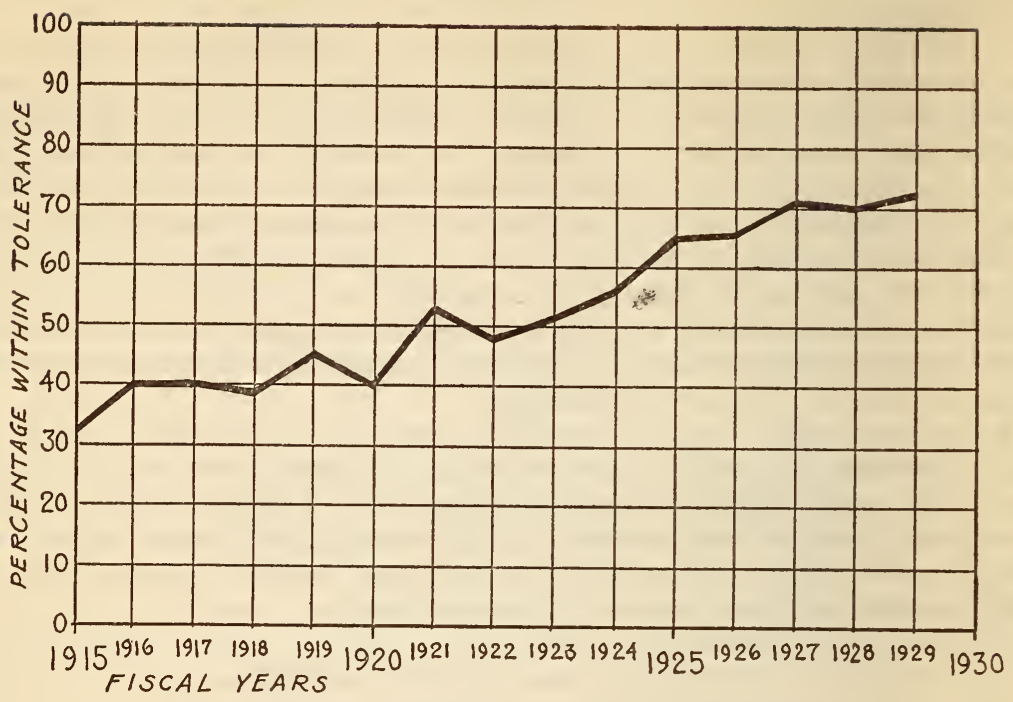

FIGURE 1.-History graph, showing for track scales tested, the percentages found within tolerance by years 1915-1929

Capacity measuring devices 98

\section{\%adjusted =condemned $\%=$ Sealed}

FIgURE 2.-Percentage analysis graph, showing for each of five kinds of measuring devices the percentages, respectively, sealed, condemned. adjusted, and nonsealed 
The white portion of each bar is proportionate to "sealed" devices; the black part shows the percentage condemned, the part shaded with sloping lines shows the percentage adjusted, and the part shaded with horizontal lines shows the percentage nonsealed. The full bars, all of the same total length, represent 100 per cent and are subdivided to show the proportions of the components, as indicated by the key. A comparison with the grand total percentages can readily be made by the eye. May I suggest the extremely useful purpose which percentages serve? The mere numerical totals may vary from place to place quite arbitrarily. The percentage analysis is, however, an important means of studying how well the sealer's work has been done or how well the trades meet the legal requirements as to weights and measures. Numbers alone are purely quantitative. The percentage analysis, however, is interpretive and useful in diagnosis of status and trend.

The percentage analysis is so important that I will show another type of graph (fig. 3) which has certain advantages over the preceding. Here is a percentage analysis in which the percentage of each component begins at the same zero, the vertical line at the left. This permits a direct comparison of each percentage with all others and with the grand total at the foot of the graph.

The fourth (fig. 4) is an organization graph of a typical weights and measures office of a large city. Vertical lines show subordination and horizontal or oblique lines show collaboration. The lines of authority are definite, even if actually complex. The units of the organization and their interrelations are shown graphically with a clearness which verbal description can not approach.

The next two graphs are of administrative interest, and show inspections by months or seasons. In the first (fig. 5) the monthly totals are plotted as points to scale above the zero line. The horizontal reference line at a height representing the monthly average, permits instant comparison of the monthly totals with this average. Note that March, May, August, and December are average months, April and October are peaks, and the minimum is in June. Seasonal and monthly deviations from the average are clearly shown by heavy vertical lines.

The same data are shown in Figure 6 by a circle graph, well adapted to portraying cycles. Each of the 12 radii represents a month. Along these the number of inspections is plotted as a distance from the center of the circle. Note that the circumference of the circle itself represents the monthly average. January, February, June, and July are, obviously, less than the average, and the peak months stand out sharply beyond the average. Also see how vividly the black parts show monthly totals below or over the average.

In our next graph a total is analyzed into its component parts. A sealer may inspect 100 weights and measures, approve 70 , reject 20 , and condemn 10. These four facts are readily shown by the graph. (Fig. 7.) A circle divided into sectors shows subtotals both by percentage and by numbers, and shows the grand total in like manner as the sum of the subtotals. The areas of the circles repre-

$24342^{\circ}-31-8$ 


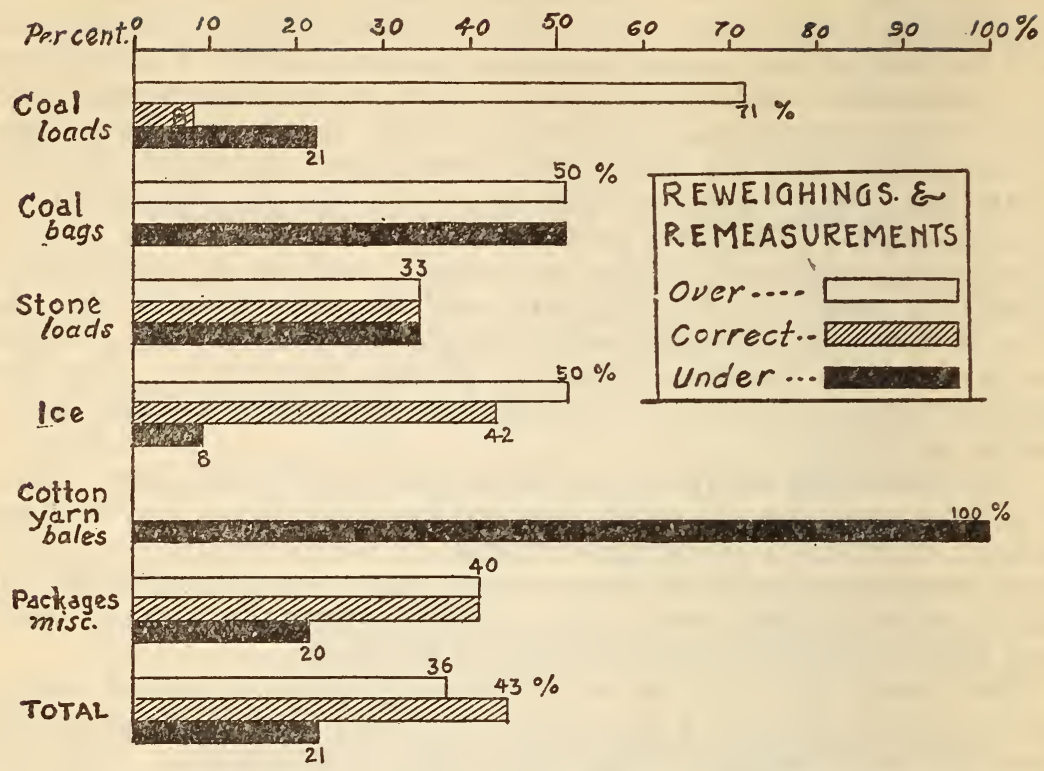

FIGURE 3.-Percentage analysis graph in which each component is plotted from a common zero to represent a percentage of each aggregate

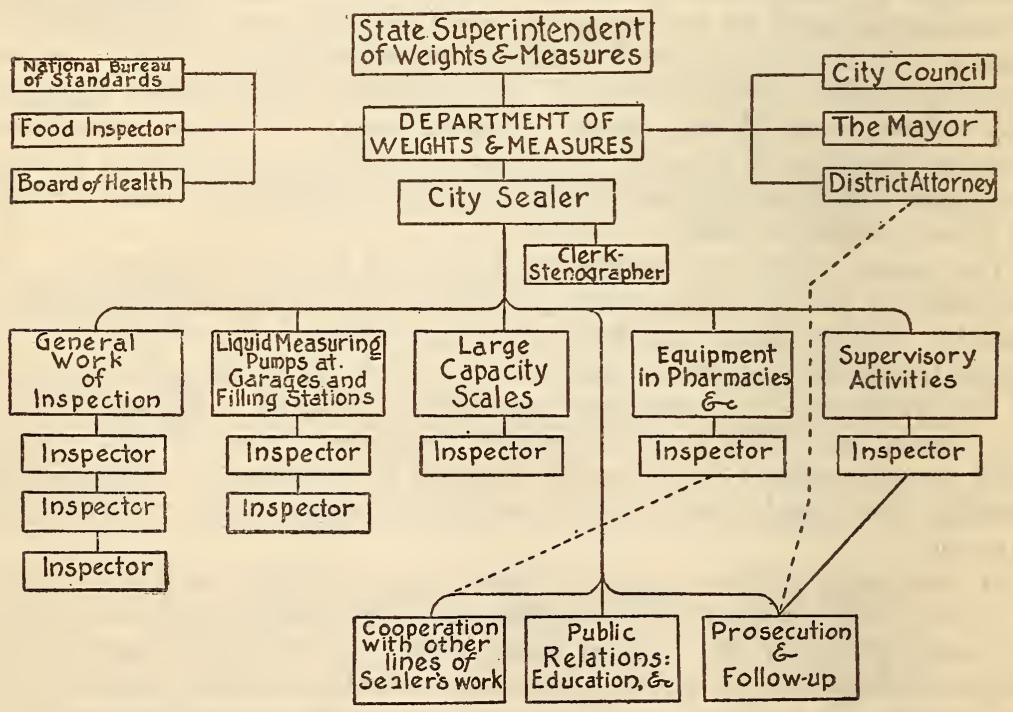

FrguRE 4.-Organiation graph showing the organization units and personnel and their interrelations 


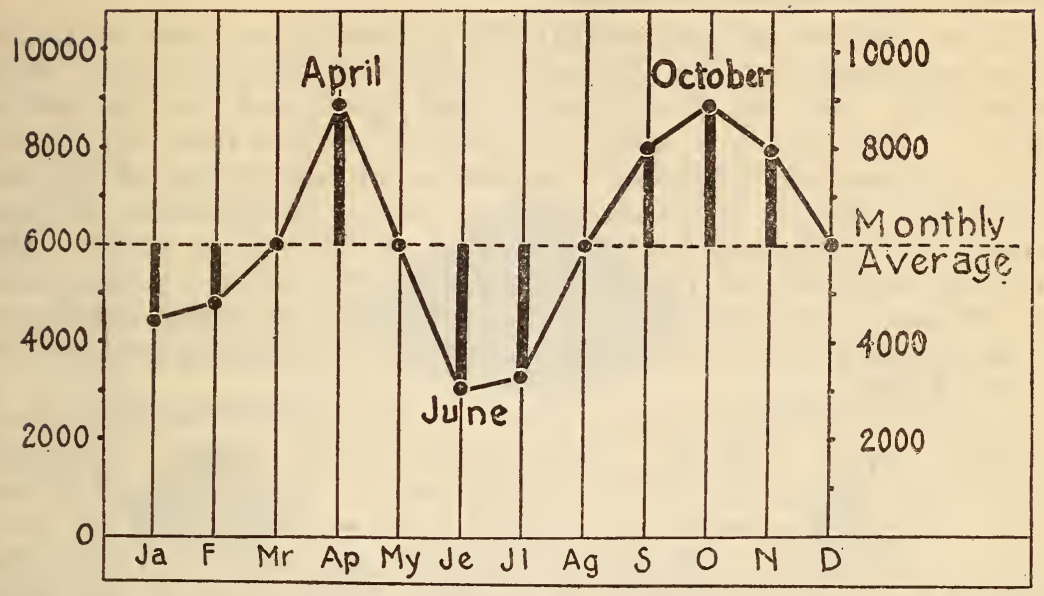

FIGURE 5.-History graph and reference average level showing comparison of monthly totals of inspection and deviations from the average

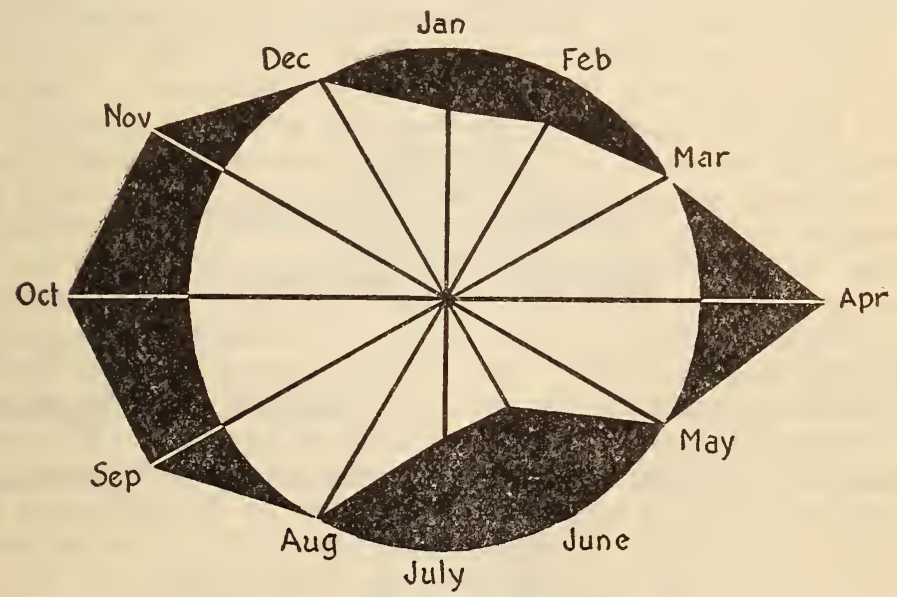

FIGURE 6.-History graph and reference average circle showing by "cycle graph" the monthly totals of inspections and deviations from the average 
sent grand totals. Conceivably, the grand totals may vary without change of percentage composition, since the angles of the sectors indicate the percentages, the entire circumference representing 100 per cent ( 1 per cent $=3.6^{\circ}$ of arc).

Figure 8 shows both numerical and percentage analysis of trackscale tests made by the National Bureau of Standards in 1929, respectively, for the West, South, and East, and for the entire country. In each test a scale has "passed," or has failed by giving either "excess" or "deficient" indication of the weight of the test standards. This is a convenient and useful combination of percentage and numerical analysis where a study is to be made. The analyzed total for the United States is shown at the top, the units for the East, West, and South being placed as they would appear on a map, respectively, in the eastern, western, and southern parts of the United States.

A very useful but unusual type of diagram is the equilateral triangle graph. (Fig. 9.) Each corner of the triangle represents 100 per cent of one of the three components. The points along one edge portray all possible proportions of two components, the midpoint representing a 50:50 2-component aggregate. Within the triangle the points represent all possible proportions of the three components of an aggregate. Here each point portrays three components of a total; for example, the center point represents three components in proportion $331 / 3$ per cent each.

Each point is located by plotting its three elements in turn toward the respective angles $A, R$, and $C$, from the opposite edge as a base. The 100 per cent interval from the base to the angle opposite is divided into 10 steps of 10 per cent each.

A single point near the apex represents $80,10,10$, respectively, and might signify, for instance, that 80 per cent of the weights and measures were approved, 10 rejected, and 10 condemned. The history of such a fact can be plotted on the same graph by a single point each year, the series of annual points showing the history of the three component proportions. The advantages of recording status and trend so vividly, comprehensively, and simply are obvious.

Another and most interesting type of graph, known as the "distribution graph," is shown in Figure 10. Here is an analysis of gasoline deliveries from various types of liquid-measuring devices, according to rate of delivery and jurisdictions where the data were secured. The grand total for each delivery rate is the height of the black column and is given numerically below the graph. The sections of each column are numbered to indicate the jurisdiction, each numbered section having a length proportionate to the deliveries in the jurisdiction concerned. It is seen that there are no deliveries at 1 gallon per minute, nor at 18 gallons per minute, and that the maximum number of deliveries is at 10 gallons. The figure as a whole shows a fairly symmetrical distribution of deliveries and would be well worth studying as to detail.

This graph was used with more detail by your secretary, Mr. Holbrook, in presenting to the conference the results of a survey of gasoline-measuring devices made by various officials, and presents a most useful method of analyzing results for detailed study. Note how easy it is to ascertain and visualize the effect of any proposal to limit 


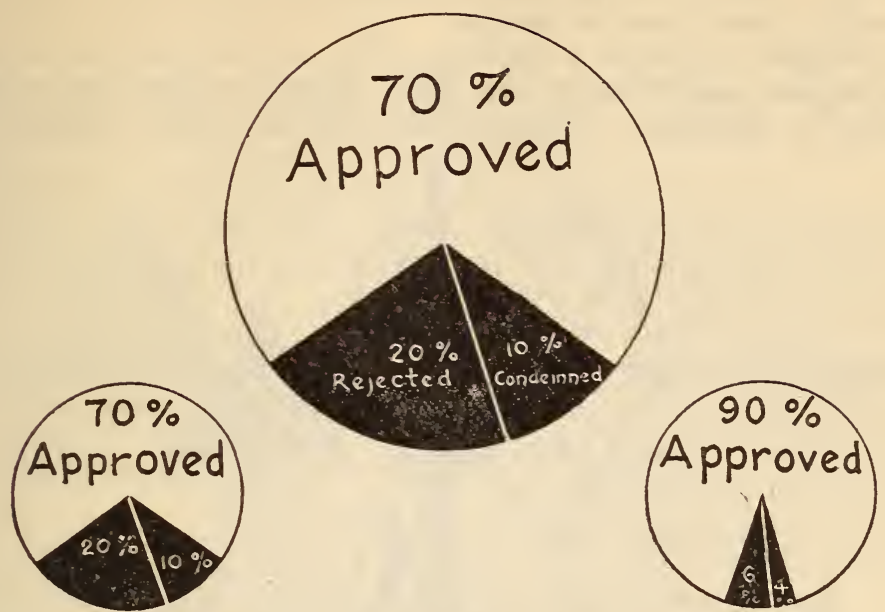

FiguRE 7.-Percentage analysis circle graph, showing the percentages, respectively, of approved, rejected, or condemned apparatus

NoTE.-In a circle graph, the area of the circle represents the grand total of units considered in the analysis. Thus, in the graphs above, the upper circle represents a total much larger than either of the lower circles; the small circles, being of equal area, represent equal totals. A given angle represents the same percentage, whatever the area of the circle. Thus, considering the upper and lower left circle, the percentages shown are the same, although the number of units comprising these percentages are much larger in the case of the upper circle. The two lower graphs illustrate an analysis of conditions before and after an effective campaign of active inspection; the total number of pieces of apparatus examined (as shown by the areas of the circles) is the same in each case, but a decided improvement in conditions is strikingly brought out by the larger angle indicating "approved " apparatus and the reduced angles indicating "rejected" and "condemned" apparatus.

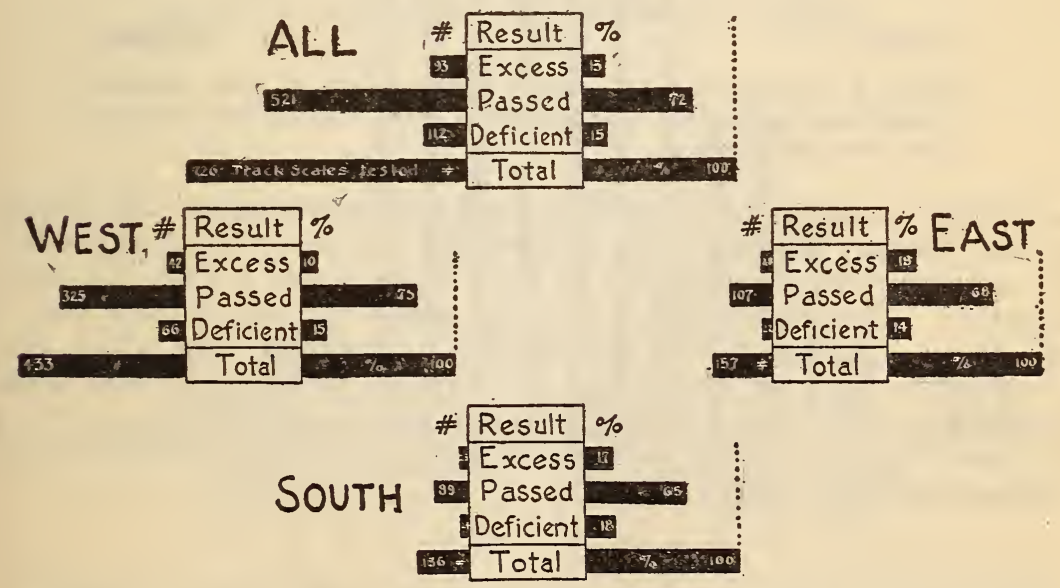

FIGURE 8.-Numerical and percentage analysis of track-scale tests, shown separately for the eastern, western, and southern sections of the United States and for the entire country 
deliveries within certain definite mazimal and minimal rates of delivery. The number of deliveries affected by any such limitation is quite readily seen from the graph.

The graphic language is modern. We are learning its alphabet. Graphs depict magnitude to the eye. They do more-they compel the seeing of relations. Stripped of needless words, reduced to di-

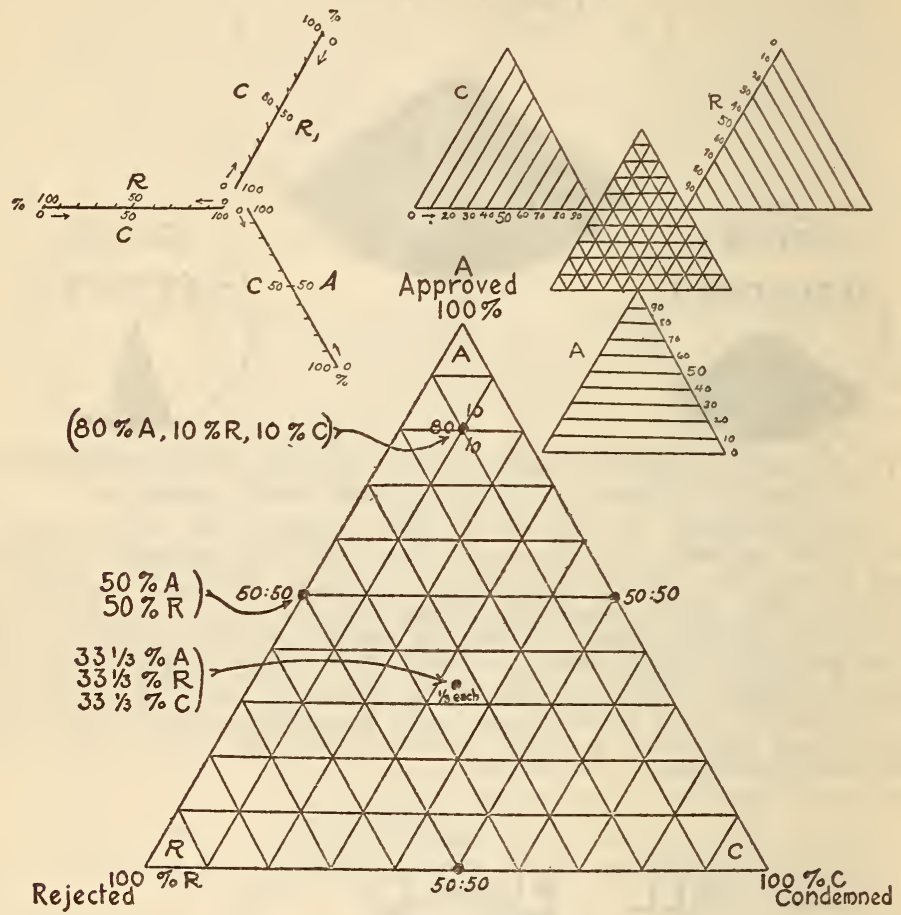

FiguRE 9.-Triangular percentage analysis graph, each interior point representing the percentages of three components of a 100 per cent aggregate

mensions, a language of quantity, vivid and unescapable. By graphs we can portray whole masses of intricate routine or the organization of an enterprise. The profile of a curve reveals in a flash the whole situation. Graphs furnish unrivaled means to record data and to tell facts. Combined with the essential numerical data which may be added to the graph, the story is complete. As weights and measures officials, we may profitably add graphic methods for recording or reporting our results, in view of the phenomenal success of such methods in other fields. 


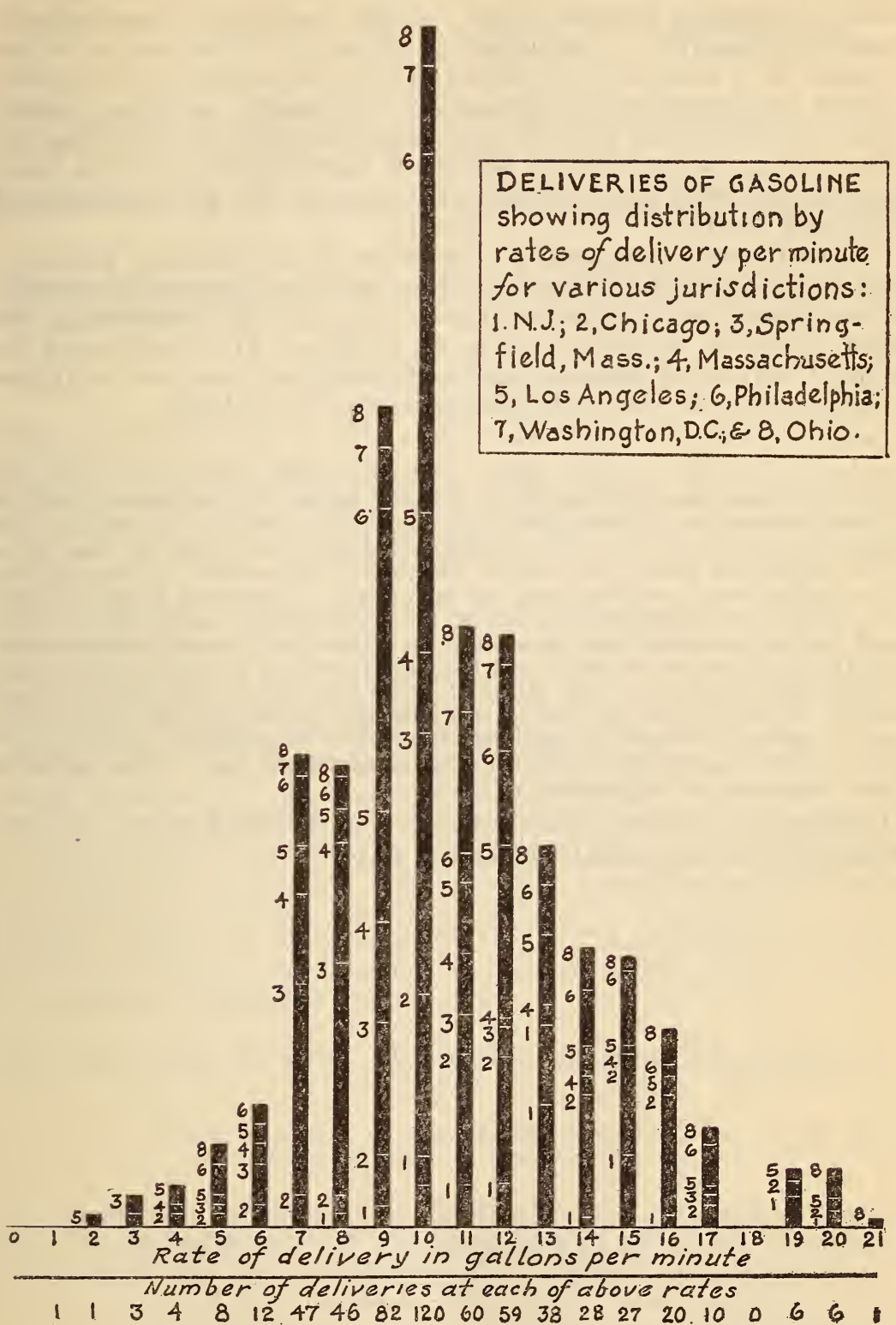

FIGURE 10.-Distribution analysis graph, showing for each rate of delivery (gallons per minute) of gasoline, the total number of deliveries in all and for each jurisdiction 


\section{DEMONSTRATION OF GASOLINE METERS BY MANUFACTURERS}

The Acting Chatrman. It is now time for the demonstration of gasoline meters by manufacturers. I will request each demonstrator to confine himself to a period not in excess of 15 minutes, of which a matter of 5 minutes may be devoted to the answering of queries.

There are a number of presentations to be made, and these demonstrations will extend into the afternoon session. At this time we might determine the order in which the manufacturers will be heard and continue with the number until the time for the luncheon adjournment arrives.

Mr. HoLBRook. Inasmuch as the order of presentation may be a matter of importance, I have written out the names of the manufacturers who will exhibit on these slips; I will shuffle them and Major Meredith will draw them at random. If he will read the names, I will write them on the blackboard, and everyone will then know the order in which the manufacturers will exhibit.

SECRETARY's Note.-At this point, and continuing immediately after the luncheon recess, the manufacturers brought before the conference samples of their meters, so disassembled that they were enabled to explain and demonstrate them to those in attendance. Particular attention was given to the manner in which the product functioned, the method of manipulation of the adjustments provided, and the answering of questions asked by members. While a stenographic record of the remarks was made, it was later found that it was practically impossible to follow this transcript intelligently when the meters were not before the reader. Therefore no good purpose would be subserved in printing this material here, and it has, consequently, been omitted. It may be said in passing that this number was of great interest and value to those in attendance and that the formal appreciation of the conference was later expressed to the manufacturers taking part. (See resolution of the conference on this subject, p. 145.)

(During the number described above, at 1 o'clock p. m., the conference took a recess until 2 o'clock p. m.) 


\section{SIXTH SESSION (AFTERNOON OF THURSDAY, JUNE 5, 1930)}

The conference reassembled at 2.18 o'clock p. m., Howard S. Jarrett, second vice president, in the chair.

\section{DEMONSTRATION OF GASOLINE METERS BY MANUFACTURERS- Continued}

These demonstrations were continued until 2.50 o'clock p. m., at which time the list of manufacturers participating was complete.

\section{DISCUSSION OF ABOVE NUMBER}

The Acting Chamman. The conference feels very grateful for the demonstrations you have given us.

The meters will be here on display, and any time anyone desires to examine them and have them further explained I am sure the representatives of the meter manufacturers will be glad to explain them to you.

Mr. Foster. Mr. Chairman, if I may be permitted, I would like to call the attention of the manufacturers' representatives who are here to-day to something that we are all aware of. I have noticed that several of these meters are equipped with a bell. From my standpoint and as a result of my observation I wish the bell was not incorporated in either the piston-type or the meter-type pump. I say this because I believe the operator is unduly influenced by the bell. For" example, on the piston pump we have had very much difficulty in that the operators stop when the bell rings. There is a very important difference between that condition and where the bell continues to ring until the indicator has dropped to zero. We have had a considerable number of complaints on that. I would like to see the meter manufacturers get together and dispense with frills which in my opinion are absolutely unnecessary.

\section{AIR RELEASES ON POWER-OPERATED GASOLINE-DISPENSING UNITS}

By A. W. Schwartz, Assistant Superintendent, Department of Weights and Measures, State of New Jersey

Mr. President, members of the conference, and guests, it is a wellrecognized fact that gasoline is a commodity of value, and it is therefore essential that it be sold through an accurate measuring device.

To place in the field a gasoline dispenser that would meet this requirement and also stand up to the specifications and tolerances as promulgated by the National Conference on Weights and Measures has been the aim of the manufacturers of the various devices now upon the market, and their engineers have given much time and study toward the development of apparatus to meet this demand. 
From the early types of piston and visible pumps great strides have been made in the progress of the industry, so that to-day meter systems are displacing the old-style method of dispensing gasoline. It is being daily demonstrated that the meter type of apparatus is becoming more popular.

In making sales of gasoline at a supply or service station it is not only desirable but essential to expedite the delivery, and it is therefore an advantage to the trade to have a suitable supply pressure as well as to operate the device at its maximum delivery on all occasions. To this end have been devised various types of power-driven meters.

The flow meter was the first in the field. Within the past year there has been a trend toward displacement or volumetric metering pumps. This started first with one, and now most of the leading pump manufacturers have a device of this type on the market or in the experimental stage.

While this type of pump has many advantages over the old "blind" pump, with its leaky foot valves and worn suction leathers, the "visible" pumps, with their 2-way valves and remote control on the nozzle, and even over the "flow" meter pump, whose accuracy is dependent upon by-passing a certain amount of liquid to make up deficiencies that are caused by the inability of a flow meter to register 100 per cent of the delivery, it has an inherent weakness that is present in all pump devices, and that is the inability to pass off air in the line and measure only gasoline. A measuring chamber will record as full capacity of fluid, whether there is no gasoline in it or whether the gasoline contains large quantities of air.

The latest step in the progress toward 100 per cent accuracy is the air-release device. This apparatus has appeared on the market within the last year. A pump with an "air regulator," an "air release," or whatever a manufacturer desires to call it, will extract the air and insure that only fluid enters the measuring chamber. It is claimed that the device thus removed the last weakness in the performance of meter pumps, and that the purchasing public is sure of a full quantity of gasoline being delivered to the car.

There are a number of reasons why air enters the gasoline line between the underground tank and the meter: Leaking lines, loose connections, air pockets, excessive lift, mechanical leaks, leaky foot valves and line valves, low level of liquid in the storage tanks, or an empty tank. It is well known to weights and measures men that many of these faults are attributable to poor installation of the pumping unit, due to the oil company letting out the installing of the pumps to the lowest bidder, with the result that the most experienced mechanics are not employed on the job. Tanks are placed in the ground rapidly with the fill shoveled in hastily; rain will settle the dirt and cause pipe lines to shift, straining the connection; rain may settle the dirt under the pump pedestal, causing it to go out of plumb; carelessly connected pump lines with too little litharge at the threads may spring a leak under pressure. When a pump is operated at night the operator at the nozzle may be unaware of the fact that his gas level has dropped too low or that the tank may even have gone dry. All of these factors make it possible for the automobilist, the man who pays for a certain amount of gasoline, to 
be defrauded, intentionally or unintentionally, by the station attendant. The fact remains that he often pays for more gasoline than he receives, whether the short measure is premeditated or is accidental.

It has been contended by some that the installation of the air release or regulator on the gas line before it reaches the meter will eliminate this short measure. From blue prints and diagrams the innovation appears to have solved the problem, but in practice the device is too new on the market to really prove that it is the panacea for the inherent ills that beset the pump.

You all know that the visigauge, the "see-glass," or whatever you may call it, has done much to take the mystery from the delivery of gasoline through the pump to the fuel tank on the automobile. Whether you are sure of getting what you ask for, the visigauge gives you a glimpse of the commodity in motion between tank and car. Since the visigauge is at the highest point on the line, it reveals to the operator and the observant driver when air is in the line. Bubbles are seen drifting through the agitated fluid, which is an indication of air, and that a resultant short measure is being delivered. A visigauge will reveal any air bubbles that enter the gas supply line through any of the causes I have enumerated above, but this is only shown after the fluid has been measured.

The testing of a pump by weights and measures officials may reveal a shortage that is greater than the tolerance allowed, and this shortage may be due to air in the line being measured and metered. This would cause the vigilant official to condemn the pump for adjustment, but since most States require only an annual test of each device, the pump may be wrong for a lengthy period without discovery. An air-release device would act as a constant guard against air mixing with gasoline and being measured as such.

Naturally the device has its drawbacks. It protects the customer, but it does nothing for the dealer, who may be losing thousands of gallons of gasoline through underground leakages that will not show above the surface of the earth. Not only would this amount to a considerable sum of money over a period of a year, but it would also create a fire hazard that could cause serious loss of life and property should the impregnated ground ignite and explosion occur.

The question of air in connection with gasoline dispensers has always been an important factor for serious consideration since the days of the first gasoline outfits, and it is submitted to you by the State department of weights and measures of New Jersey that in the power-driven types of metering equipment it is possible to provide practical and dependable means for eliminating this undesirable factor.

The subject of air-release devices is one on which the State department of weights and measures of New Jersey has an open mind, and it is felt that it should not be accepted as a cure-all for short measure of gasoline, simply because it is an innovation. It has merits that seem worthy of our consideration, it has strong points that should make us look with favor upon its adoption, but not, however, before the device has been through the proving ground of practical use under all climatic and mechanical conditions.

Mr. Meredith. Mr. Chairman, the program indicates that the next number is a paper prepared by myself. As a matter of fact, 
this paper is rather a composite composition of the inspectors of my division, men who are practical in every sense of the word and have gained their knowledge and experience in actual contact with devices and conditions which they meet and have to deal with in their work.

\section{TESTING VEHICLE-TANK METERS}

\section{By Massachusetts Inspectors of Standards ${ }^{\circ}$}

While this paper is intended to deal specifically with meters installed upon vehicle tanks, much of the subject matter will be found applicable to all delivery systems in which a meter is used as the measuring element in connection with a power-driven pumping unit.

Experience teaches that a meter will record air or vapor as readily as it indicates the volume of liquid which passes through it. It is therefore important that the pipe lines, valves, stuffing box, and connections be air-tight. The suction incident to the pumping process is sufficient to draw a considerable quantity of air through a leak so small that little, if any, gasoline can seep through it.

It is also essential that the opportunity for air pockets be reduced to a minimum by eliminating all unnecessary elbows, angles, or bends in the pipe lines. Where an air pocket exists in the line, the entrapped air expands and contracts alternately as the pump is operated or stopped. As this contraction occurs it causes a suction sufficient to draw air into the line at any point where even the slightest opportunity for leakage exists.

Especially where a power pump is used, the pumping process causes the liquid to "break." In other words, it destroys the cohesion of the liquid particles and introduces bubbles of air or vapor which, unless eliminated, will have their volume recorded as they pass through the meter with the liquid.

In delivery from a vehicle tank, a centrifugal motion is set up as the liquid lowers in the tank, forming a miniature whirlpool in line with the suction pipe. The bottom of this whirlpool is constantly lower than the level of the liquid and eventually becomes lower than the end of the suction pipe so that a considerable quantity of air may be carried along with the liquid.

Gasoline also invariably contains more or less dissolved air which has been introduced by exposure to the atmosphere, or by the pressure of air in a closed container, the amount depending upon the volatility of the gasoline and the conditions under which it is stored. As outlined at the Twenty-second National Conference by Dr. Oscar C. Bridgeman, experimental work at the Bureau of Standards showed that a highly volatile aviation gasoline will dissolve about onefourth of its own volume of air, while the ordinary motor gasoline will dissolve about one-sixth of its volume when both are put under an air pressure of 14.7 pounds per square inch.

Having shown the various conditions under which gasoline and, to a lesser extent, other fuel oils may become impregnated with air, the next step is to determine the possible effect of this air upon the accuracy of the meter or other measuring device which indicates the purported volume of liquid discharged.

6 This paper was presented to the conference by Francis Meredith, director of standards, State of Massachusetts. 
In discharging gasoline or fuel oil from a vehicle tank, through a meter supplied by a power pumping unit, the presence and registration of considerable quantities of air were self-evident. It then became a question as to the extent to which this might also be true when such meters were supplied by gravity flow. To determine this point, a measured quantity of 100 gallons of gasoline was placed in a truck tank having a float control valve installed in the line between the tank and the meter and designed to close as the last of the liquid left the tank and thus exclude air carried along by suction as the tank emptied. Upon this test the meter accurately registered the quantity of liquid discharged.

A similar test made with the same quantity of gasoline, after disconnecting the bleeder pipe from the float-control valve and rendering the latter inoperative by jacking up the valve lift spring, showed an overregistration of approximately 2.7 gallons caused by the registration of air.

Tests of a meter, where a motor-driven pumping unit was used in connection with a vehicle-tank installation, showed excessive and widely varying errors at different times, although an "air separator" was installed between the pump and the meter. The first of these tests, made early in March, involved a 2-compartment tank, the compartments having been calibrated as containing 504 and 503 gallons, respectively. The 504-gallon compartment was filled to capacity with gasoline, which was then pumped through the meter into the second compartment at a constant rate of 47 gallons per minute. The meter showed a purported discharge of 5183/4 gallons, an overregistration of $143 / 4$ gallons. The operation was then reversed by pumping the liquid back to the first compartment, the meter upon this test showing an overregistration of $541 / 2$ gallons.

Early in August a meter of the same type was tested under what might be termed "ideal conditions." An improved type of air separator was used, and the test was made by a representative of the meter manufacturer. The meter was installed on an underslung platform near the cab on the right-hand side of a 2-compartment tank truck. The pumping unit was located on opposite side of truck and was operated by means of the truck motor. A relief valve was installed close to pumping unit. Between the pump and the meter a hand-controlled valve, a strainer, and an air separator were installed in the order named. Between meter and outlet a backpressure relief valve helped to preserve a normal pressure. Pipe lines and joints were air-tight, and there was no opportunity for air pockets.

A measured quantity of $5021 / 2$ gallons of gasoline was placed in one of the tank compartments and then pumped into the empty compartment, the rate of flow being 48 gallons per minute. Upon this test the meter indicated discharge of 502 gallons, an error of only one-half gallon. While the results of this test showed a wonderful degree of accuracy, they were not indicative of what might be found under average conditions of installation and distribution, so a series of tests was subsequently made in order to determine the effect upon the accuracy of meter indications when air or vapor was present in appreciable quantities. 
Within the next week another test of the same meter was made, furnace oil being used as the testing medium. A compartment containing 5021/2 gallons was emptied through the meter, the shut-off valve of the adjoining empty compartment being open, and the pumping operation being accelerated as much as possible by gradually advancing the hand throttle of the motor. This acceleration apparently had little effect upon the rate of flow, which ranged from 50 gallons per minute at the start to 47 gallons per minute when 300 gallons had been discharged, and thereafter gradually diminished as the supply decreased. It did, however, materially increase the surging and consequent breaking up of the liquid. At the completion of delivery the meter reading showed an apparent discharge of 605 gallons, an overregistration of 102.5 gallons.

Early in October, additional tests of this identical equipment were made, some adjustments having been made in the meantime by a member of the engineering department of the meter manufacturer. During these tests the shut-off valve of the empty compartment was left open as before. The 5021/2-gallon compartment was filled and contents metered through 2-inch hose to compartment of another truck tank, the rate of flow being purposely varied during the test. The rate for the first 150 gallons was 36 gallons per minute, for the next 70 gallons, 44 gallons per minute; for the next 100 gallons, 33 gallons per minute; and for the remainder, 36 gallons per minute. Upon this test the meter showed an overregistration of 7 gallons. The 5021/2-gallon compartment was refilled and contents metered to another tank, the motor being gradually accelerated during operation. The rate of flow for the first 120 gallons being 54 gallons per minute, for the next 100 gallons, 42 gallons per minute; for the next 60 gallons, 40 gallons per minute; for the next 125 gallons, 32 gallons per minute, the rate thereafter not being determined. The meter showed an overregistration of 15 gallons at the conclusion of this test.

In the foregoing tests the acceleration of the motor and the opening of the valves in the empty compartments were designed to produce conditions under which the efficiency of the meter and the air separator could be determined with a maximum amount of air to be eliminated. It appearing quite possible, however, that similar conditions may sometimes be found in everyday practice, a further series of tests was made in November, with an expert service man present to observe results and determine what changes or adjustments might tend to eliminate erroneous registration or reduce errors to a minimum. A known quantity of 769 gallons of furnace oil was metered from a tank compartment into an underground tank, with motor accelerated and valve of empty compartment open, the meter showing an overregistration of 26.9 gallons. The expert then made adjustments of the back pressure and pump-relief valves, the compartment was refilled and test repeated, the overregistration being reduced to 16.6 gallons on this test. A further adjustment of the relief valve only was then made and the test again repeated, the overregistration being reduced to 8.9 gallons. The rate of flow at beginning of first test was 45 gallons per minute. After the first adjustments were made the effect was shown in a reduction of the flow to 43 gallons per minute and after the final adjustment it was 42 gallons per minute. 
The method of testing, by means of the standard test measures ordinarily employed by weights and measures officials in testing retail metering systems is of little value when applied to a meter used in delivering wholesale quantities from a truck tank. In the latter case the test should include metering from the tank compartment of a considerable predetermined volume of liquid, preferably the full capacity of the compartment. In testing, the following precautions should be observed:

1. See that the compartment to be employed and the pipe line leading therefrom are completely emptied, starting the pump if necessary to insure this empty condition.

2. See that outlet valves are tightly closed; then place a measured volume of liquid in the compartment (not less than 100 gallons in any case).

3. Having taken the meter reading, open the outlet valve of the compartment and start pumping operation, discharging liquid at normal rate of flow through hose, preferably into an empty compartment of the same truck, so as to facilitate a retest with an expenditure of the least amount of extra time and labor. The fill opening at the top of the compartment being uncovered during test, it is easy to observe whether there is an undue agitation causing a breaking of the liquid during the pumping process. There should also be a careful inspection of the entire discharge line in search of possible leaky joints or opportunities for air pockets in the line, as such conditions, if found, may account for errors observed when final meter reading is made upon completion of delivery. The rate of flow should also be determined from time to time, as the test proceeds, and compared with the rates prescribed by the manufacturer for the particular type of meter under test.

4. When a meter is installed upon a gravity flow line, without auxiliary pumping unit, a test similar to that described above should be employed with necessary variations because of the fact that liquid must be discharged into a container placed at a lower level in order that the law of gravity may operate.

5 . When meter readings are found to be correct within tolerance, seals should be employed at all points where adjustments are possible which might affect the meter registration.

(At this point Mr. Meredith, first vice president, assumed the chair, succeeding Mr. Jarrett, second vice president.)

\section{DISCUSSION OF ABOVE PAPER}

Mr. Kelly. Mr. Chairman, may I ask a question about that paper that you have just presented. I would like to ask what, in your opinion, is the value of testing a tank wagon by means of a meter as compared with a test using a calibrated tank? Which do you consider the more accurate?

The Acting Chatrman. I think a test with the calibrated tank would be preferable. We are inclined to work toward that. 
By H. N. Davis, Deputy Commissioner of Weights and Measures, State of Vermont

Mr. Chairman and delegates, doubtless many of you who are officials of weight and measure departments have been asked why vehicle tanks, used as measures for the delivery of petroleum products, were not calibrated to determine their correctness the same as other containers used as measures. It was because this question was so frequently propounded and the demand so insistent that the weights and measures department of Vermont was sponsor of a bill before the legislature of 1929 , designed to make it compulsory for the distributors of fuel oil and gasoline to equip their vehicle tanks with meters to determine the amount delivered to each individual customer; the delivery was to be paid for on the basis of the meter reading. This bill was opposed very strenuously by the oil distributors, and a substitute bill was reported out from the ways and means committee requiring distributors of petroleum products to have all tank vehicles used by them calibrated under the supervision of the weights and measures department. This bill was passed and became a law.

A letter in the form of a questionnaire was sent out by our department to each distributor of gas and oil, requiring him to give us information as to the number of vehicle tanks operated in Vermont, the number of compartments in each tank, the truck number, and the State license number of each truck. Specifications and tolerances which apply to vehicle tanks and accessory piping and ralres, whenever the tanks or compartments were used as measures, were also sent out. These specifications required an adjustable indicator in the fill opening, which could be sealed at a point which would determine the correct gallonage as stenciled on the outside of the dome of the compartment. Expansion space was allowed for change in volume occasioned by temperature. After experimenting with a 50-gallon measure and bucketing out in 5-gallon test measures we decided on a meter system of calibration, and a meter was purchased for that purpose.

Our method of calibration has been by gravity, using gasoline from the overhead storage tanks of the distributor. The work was done during the winter months when the temperature would not affect the measurement as much as in the hot weather. Before putting the 11/2-inch meter into service it was carefully checked with a 50-gallon test measure. Also, 50 gallons of light oil was run through the meter into a vehicle tank and bucketed out with sealed 5-gallon test measures. The inaccuracies in these tests negligible. The meter was attached to the rear end of an automobile and securely fastened in place, and it remained in this position while calibrating the vehicle tanks. A 10 -foot length of $11 / 2-$ inch hose was attached to the discharge of the distributor's storage tank by means of reducing couplings, to the intake of the meter. Another 10-foot hose was attached to the discharge side of the meter, reaching to the compartment to be calibrated. The flow of the prod- 
uct through the meter was controlled by a quick-action nozzle valve at the end of the hose on the discharge line of the meter. The nozzle was carried well down in the compartment. Before starting the test for verifying the capacity of the compartment, great care was taken to expel any air that might be in the hose line or meter. Tests were made with a 5 -gallon test measure before each compartment was calibrated. When great discrepancies between the distributor's measurement and the meter were found, the contents of the compartment were drawn off and the compartment rechecked. Most of the distributors at first were skeptical about the use of the meter for accurate measurement and had to be shown that it was dependable and even more accurate than bucketing or pin gaging the compartment. The meter was checked against vehicle tanks coming from Massachusetts and New York which had been calibrated, the filling points sealed, and capacities marked, and the discrepancies, varying from 54 to 10 cubic inches in deficiency, were surprisingly small. Several meters installed by distributors at their storage plants, used to check their product from storage to vehicle tanks and from tank cars to storage, were checked and the errors found were very small, except in one instance. We were very well satisfied with our tests and received the cooperation of every distributor doing business in the State. We sometimes had to prove our premise by bucketing out a compartment of water, but were able to maintain our position. An officer of one of the large refining companies came to witness the calibration of their tanks and expressed entire satisfaction with results obtained with the meter. I will give a few examples of the results of tests made.

Report of tank-truck inspections for Decenber. 11, 1929

Oil Co., Burlington, Vt.,

Truck No. 7365 :

Front compartment, marked capacity, $408 \frac{3}{16}$ gallons; calibrated 408.9 gallons.

Rear compartment, marked capacity, $4061 / 8$ gallons ; calibrated, 406.6 gallons. Truck No. 7881 :

Front compartment, marked capacity, 4411/2 gallons; calibrated, 441 gallons. Rear compartment, marked capacity, 441 gallons ; calibrated, 440.9 gallons.

Truck No. 8833 :

Front compartment, marked capacity, 4441/1 gallons; calibrated, 445 gallons. Rear compartment, marked capacity, $442 \frac{1}{1} 1$ gallons ; calibrated, 443.6 gallons. Truck No. \$ $\$ 61$ :

Front compartment, marked capacity, 4421/1 gallons; calibrated, 444.5 gallons.

Rear compartment, marked capacity, 439 gallons; calibrated, 441.2 gallons. Truck No. 7366 :

Front compartment, marked capacity, 408 gallons ; calibrated, 407.7 gallons. Rear compartment, marked capacity, 406 gallons; calibrated, 404.8 gallons. Truck No. 7911:

Front compartment, marked capacity, $4381 / 2$ gallons; calibrated, 440.8 gallons.

Rear compartment, marked capacity, $438 \%$ gallons; calibrated, 439.5 gallons. Truck No. 7364 :

Front compartment, marked capacity, 408 gallons; calibrated, 409.3 gallons. Rear compartment, marked capacity, 406 gallons; calibrated, 408 gallons. $24342^{\circ}-31 \longrightarrow 9$ 
Truck No. 7896:

Front compartment, marked capacity, 4421/2 gallons; calibrated, 442.8 gallons.

Rear compartment, 'marked capacity, 442 gallons; calibrated, 441.5 gallons.

Verified truck No. 8833, rear compartment, and truck No. 8861, front and rear compartments.

HARRY C. MOORE, Inspector.

Report of tank-truck inspections of December 20, 1929

Truck No. 1:

Coal \& Fuel Co., Burlington, Tt.,

Compartment No. 1, marked capacity, 305 gallons; calibrated, 302 gallons.

Compartment No. 2, marked capacity, 204 gallons; calibrated, 202 gallons.

Compartment No. 3, marked capacity, 102 gallons; calibrated, 101 gallons.

The capacity as calibrated to points which were recently put in, and which

$I$ advised them to fill to, is as follows:

Compartment No. 1, 299 gallons.

Compartment No. 2, 199 gallons.

Compartment No. 3, 99 gallons.

Truck No. 2:

Compartment No. 1, marked capacity, 313 gallons; calibrated, 302 gallons.

Compartment No. 2, marked capacity, 202 gallons; calibrated, 203 gallons.

The capacity as calibrated to points which were recently put in, and which I advised them to fill to, is as follows:

Compartment No. 1, 294 gallons.

Compartment No. 2, 196 gallons.

HARRY C. MOORE, Inspector.

One hundred sixty thousand nine hundred and thirty-nine gallons of gasoline and light oil were run through the meter to calibrate 630 compartments, with only one adjustment of the meter. No differences were discovered in meter due to different heads of liquid. Tests will be made in summer with meter to ascertain differences due to temperature effects.

I am not so sure that any great benefit will be derived from this work. The vehicle tank must be in nearly a level position at the place of delivery, and atmospheric conditions must be about right, or the purchaser at the filling station will not be able to determine accurately the amount delivered, by inspection of the sealed filling point at the time of delivery. However, the public feel that their interests have in a measure been safeguarded and that they will benefit by our work.

\section{DISCUSSION OF ABOVE PAPER}

Mr. Melidy. Mr. Chairman, I would like to ask Mr. Davis from Vermont a question. When you seal tank compartments, do you have any trouble with seals broken on reinspection.

Mr. Davis. You see our work is of very recent origin so we have no experience on that point.

Mr. MeLidy. In Worcester when we have made a calibration we seal an indicator in the top of the dome. We measure the exact distance of that indicator from the top and write it in our description in the sealer's certificate of the truck. If we have a broken seal, instead of making a retest we consult our records and reset the indicator in the dome. That method saves considerable time.

Mr. Davis. That is a very good suggestion and we appreciate it. That will save the necessity of rechecking it.

Mr. PAYNe. One of our New York State sealers advises me that he has a meter for calibrating gasoline vehicle tanks and that with 
the meter one inspector can calibrate a 1,500-gallon tank with 4 or 5 compartments in about 2 hours. He does not hestitate to say that the meter is more accurate than the old method of drawing it off in 5-gallon measures.

Just last year 45 tank trucks were calibrated, and when several changes were made in ownership the new firms all sent their tank trucks to be calibrated again. In every case the meter was used and the capacity of each compartment was found to be the same as formerly. All of the tanks formerly calibrated with the 5 -gallon measure were retested with the result that most compartments were found to vary from 1 to 2 gallons. Considering time, labor, and accuracy, the meter is preferred for that kind of work.

Mr. Foster. Mr. President, I would like to ask the gentleman from Worcester how they fix the indicator at the filling point so that there is no question of its moving. How is that accomplished? Mr. MeLids. We have the indicator welded to the dome so that there is no question about it.

Mr. SweEney. Mr. President, in sealing tank wagons in Boston we have devised a scheme of boring a hole through the indicator, then we put a threaded screw through that with nuts on top and bottom; the screw is perforated and the pressure is against the disk, and it is impossible to knock the seal off. We prefer that to hanging the seal by a wire.

Mr. Meuidr. Mr. President, I understand that all vehicle tanks have an adjustable finger to raise up and down in the dome. If you get this finger or indicator down into the compartment the chance of error in filling is very much increased. In a 12-inch dome a quart will cause a drop of about one-half an inch.

When we have calibrated a tank we tack up in the cab the sealer's certificate giving the date of the test, the number of the tank, and the amount which each compartment holds. The customer can ascertain from this the amounts being delivered.

A Mandfacturer's Representative. Mr. Chairman and gentlemen, I wish to suggest that the compartment is large and the dome small, and if the indicator is not put down into the compartment, in hot weather like to-day the expansion of the gasoline might cause it to spill over the street and result in a fire hazard which, in the last analysis, would be worse than taking a chance on short measure.

The Actixg Champian. I quite agree with you; there should always be an adequate expansion dome. Sometimes we notice that the construction of the domes is not always in accord with that idea. Sometimes I believe there are means provided whereby the opportunity is created to take care of expansion in a different fashion.

\section{CAIIBRATING VEHICLE TANKS BY LARGE-CAPACITY IMEASURES}

\section{By S. T. GrIfrith, Chief, Division of Weights and Meisures, City of Baltimore, $M d$.}

Mr. President, members of the conference, and visitors, before beginning to describe the method used by the division of weights and measures in Baltimore for calibrating vehicle tanks by largecapacity measures, may I invite your attention briefly to a phase of the dispensing of petroleum products which during the past year 
has arisen in Baltimore. It seems to fit in here with the discussion we have already had on the use of various meters.

I refer to the sale of fuel oil on the basis of the readings of individual household meters. Some time ago, one of the nationally known oil burner companies proposed to install in Baltimore their oil-burner system in private residences, to which would be attached a meter for the purpose of indicating the amount of fuel oil consumed, and it was their idea to charge the householder only for the amount consumed, as indicated on said meter.

The plan apparently appealed to the public for the reason that they were accustomed to pay for the gas and electricity consumed in their homes by the monthly readings of meters. This company felt that the psychological effect on the consumer would be such as to assure him of a more equitable plan of buying fuel oil; and if the oil meter was tested and approved by the proper municipal authority, it would establish its accuracy and thus eliminate complaints and contentions pertaining to short measure, which now constantly arise at various times under the usual system of delivery of fuel oil in bulk to the individual storage tanks.

This company applied to the division of weights and measures of Baltimore for the testing and sealing of these meters for accuracy. The meter offered for test was of a type widely used throughout the United States for registration of water, but it was realized that to test this meter for oil, it would require a different method from that used for water purposes. We, therefore, requested the chief engineer of Baltimore for permission to secure the necessary equipment, but instead of accomplishing this, the matter was referred to the city law department, who decided that this particular phase of measuring was not contemplated under the statute which empowered our department to test and seal all weighing and measuring instruments used in trade.

It was held that the installation of this meter in a private home did not place it within the purview of public trade. Application was then made by the oil-burner company to the public service commission, who in our city have supervision over gas and electric meters, but they declined to test these devices, probably because of lack of universal use. Nevertheless, while all this correspondence was going on, our office, anticipating that in the final outcome the division of weights and measures might be called upon to make these tests and inspections, proceeded to work out a method, and, with the assistance of Mr. Smith, of the division of weights and measures of the Bureau of Standards, worked out the following plan:

It was intended to hook up these meters in series so as to test 20 or 30 of them simultaneously. The conditions of the test were to simulate, as nearly as possible, the exact conditions that would exist in the individual household, and the tests, therefore, were to be made with the actual fuel oil that was to be consumed. On the small storage tank with a capacity of 77 gallons, a motor was to be attached to pump the oil through the meters arranged in series at the same speed as maintained under actual operation in the home.

The oil would be pumped through one line of meters and returned through the other line of meters into a measuring tank holding 65 gallons, and calibrated in gallons by means of a gage on the outside of the tank. This gage would indicate the quantity passed through 
the meters, by a float resting upon the surface of the oil within the calibrated tank and operating in a groove up and down the gage on the outside. The meters would be so mounted that any one of them could be removed without disturbing the rest; and readings were intended to be taken over a period of time extending through 24 hours.

The rack on which the meters were to be set up was to be so constructed that the entire body of the two lines of meters could be inverted at will so as to exclude all air which might be trapped in any one of the meters; this would assure a continuous flow of a solid column of oil. This plan of test should have proven highly successful, but unfortunately, through the decision of municipal authorities, we never had a chance to work it out. It was thought, however, that you might be interested in the plan of inspection.

The oil-burner company installed about 60 of these meters in various homes in the city of Baltimore, and furnished our office with a letter listing the locations, but as we were estopped from testing these meters, no investigation was made. Upon receipt of Mr. Holbrools's request that we describe this phase of dispensing petroleum products, inquiry was made with the oil-burner company only to learn that they had temporarily abandoned the project for the reason that the meters used proved entirely unsatisfactory.

The company had gone ahead with the plan, as originally outlined, but found that the meters in nearly every instance registered from 10 to 50 per cent less than the actual quantity of oil consumed, due to the fact that they became gummed or corroded with the deposits of matter contained in the fuel oil. In some instances the meters had ceased registering entirely, with the result that under their contract with the individual householder to pay only for what the meter read each month, they were unable to collect for the actual amount of fuel consumed, although they were able to show the individual that the meter was not registering correctly. Of course, some adjustments were made, but in the end, the oil company lost thousands of gallons due to the fact that the meter used was entirely unsatisfactory, and to-day they have removed every meter and are now dispensing their fuel oil by vehicle tank as the other companies are doing. I have here for your examination one of these meters. The oil-burner company, however, advised that they were still working on the plan with a hope of finding a meter which would be adequate and accurate enough to carry out their original intention of dispensing their fuel oil on the monthly reading of the individual meter.

Now, in regard to calibrating vehicle tanks by large-capacity measures, which is the title of the subject assigned me on our present program, in Baltimore we have found great success with the use of a 100-gallon and a 50-gallon test measure. The division of weights and measures has tried to make use of the many valuable ideas which have been promulgated in the several annual meetings of this conference, and the writer has referred to previous reports for methods to follow. It seems to us, however, that none were susceptible to the accuracy and speed that might be attained with the use of largecapacity measures.

In the past few years, we have tested a number of tank vehicles with the 5-gallon test measure, only to find that this method, while 
fairly accurate, is slow and tedious. Our first attempt with largecapacity measures was with a 100-gallon test tank alone. With the use of this measure we were enabled to cut down the time of handling a tank vehicle to less than one-third of the time required with the 5-gallon measure. We first used this 100-gallon measure by placing the same above the openings of the different compartments and filling to a certain designated mark, following the specifications for tank vehicles, as previously laid down, which provide for the filling of each compartment with all valves open. We used a small rod which was passed through the manhole cover to each compartment and had a crowfoot bend to register the point in the compartment at which it was calibrated. This marker was sealed through the rod and a castellated lock nut; the lead seal wires were passed through both and secured them permanently. We also attached our usual current-year seal tag, which enables us to determine at a glance that a passing tank vehicle has been calibrated.

The 100-gallon test tank was then removed to a point below the outlets of the compartments and the compartments were emptied through it. This enabled us to make a double check by comparing the results of the two calibrations. This double check naturally slowed up the work considerably, but it gave us a more accurate calibration. We nevertheless ran into the problem of still having to use 5-gallon test measures to complete a compartment, as the capacity was seldom, if ever, found to be in exact multiples of 100 gallons.

We therefore asked several test-measure companies if they would make up a 50-gallon test tank, and one company furnished us with this size of measure also. We then found that with the 50-gallon and the 100-gallon sizes we could calibrate vehicle tanks with much more facility and speed and accuracy.

In one of the city yards in Baltimore a platform was suspended from the steel roof girders of a building sufficiently high to permit any size tank vehicle to drive under it. Upon this we have permanently mounted both the 100-gallon and the 50-gallon test-tank measures.

In the use of these large-capacity measures as furnished by the manufacturer it was found impracticable to fill them to an exact zero reading because of the lack of control of the flow of water, which was used as a testing medium. We devised a plan of inserting a small pet cock in the neck of each measure, so that it is now easy to control the filling of each tank to an exact zero indication. Where before it had been necessary to draw off any excess through the main outlet, which is 2 inches in size, now we can drain through this pet cock very easily and quickly.

Most compartments of vehicle tanks contain a quantity somewhere near the half or even hundred gallon mark. In other words, they usually run in odd quantities of, say, 140,165, 215, 230, 265, and so on, increasing by multiples of 50 or 100 gallons. We fill both the 100-gallon and the 50-gallon test measures as many times as is required for the approximate capacity of the compartment under test, and then make the final filling with one or two small measures. If a compartment, upon examination, for instance, is found to hold about 295 gallons, the 100-gallon test measure is emptied and two 


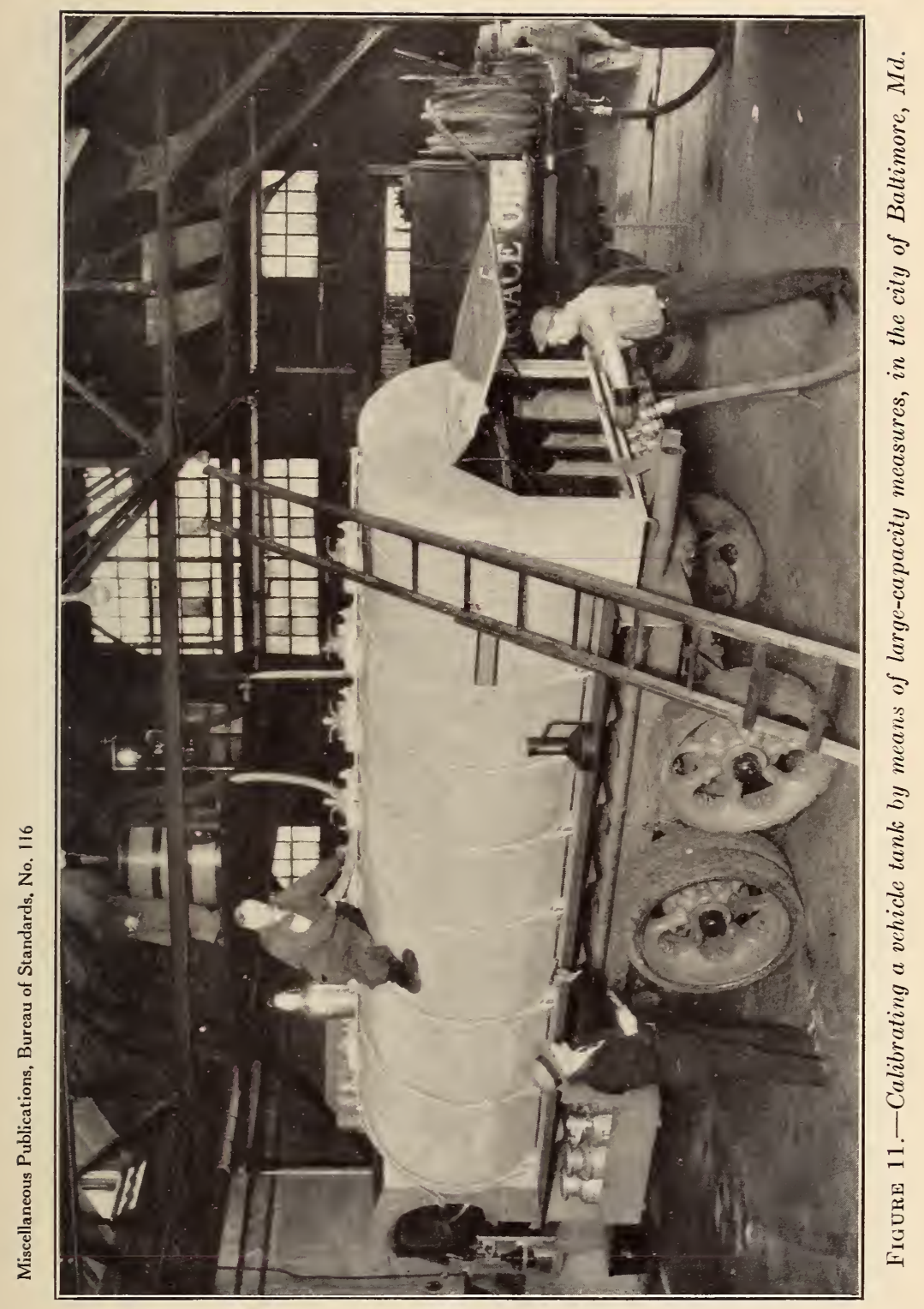




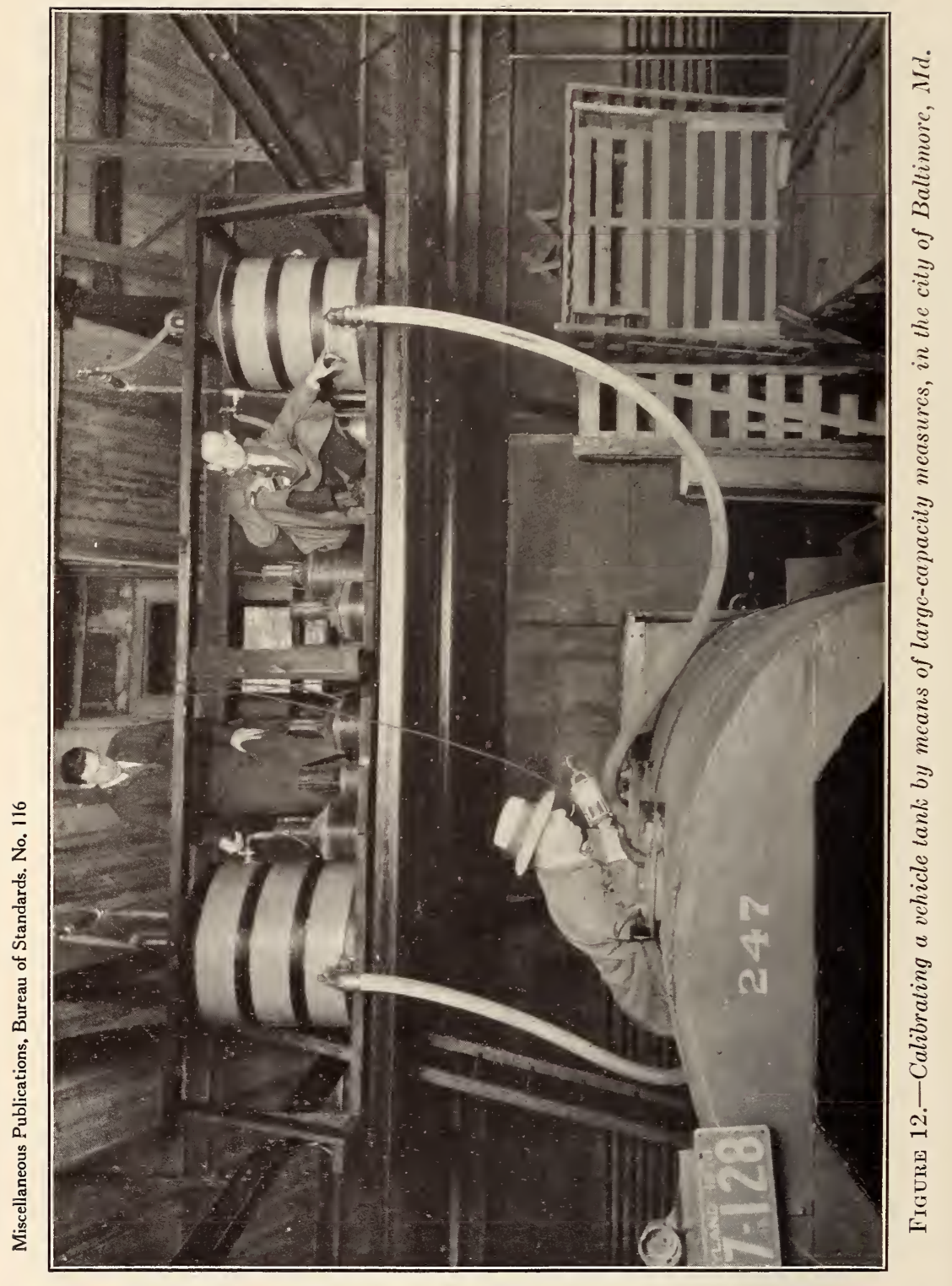


Miscellaneous Publications, Bureau of Standards, No. 116

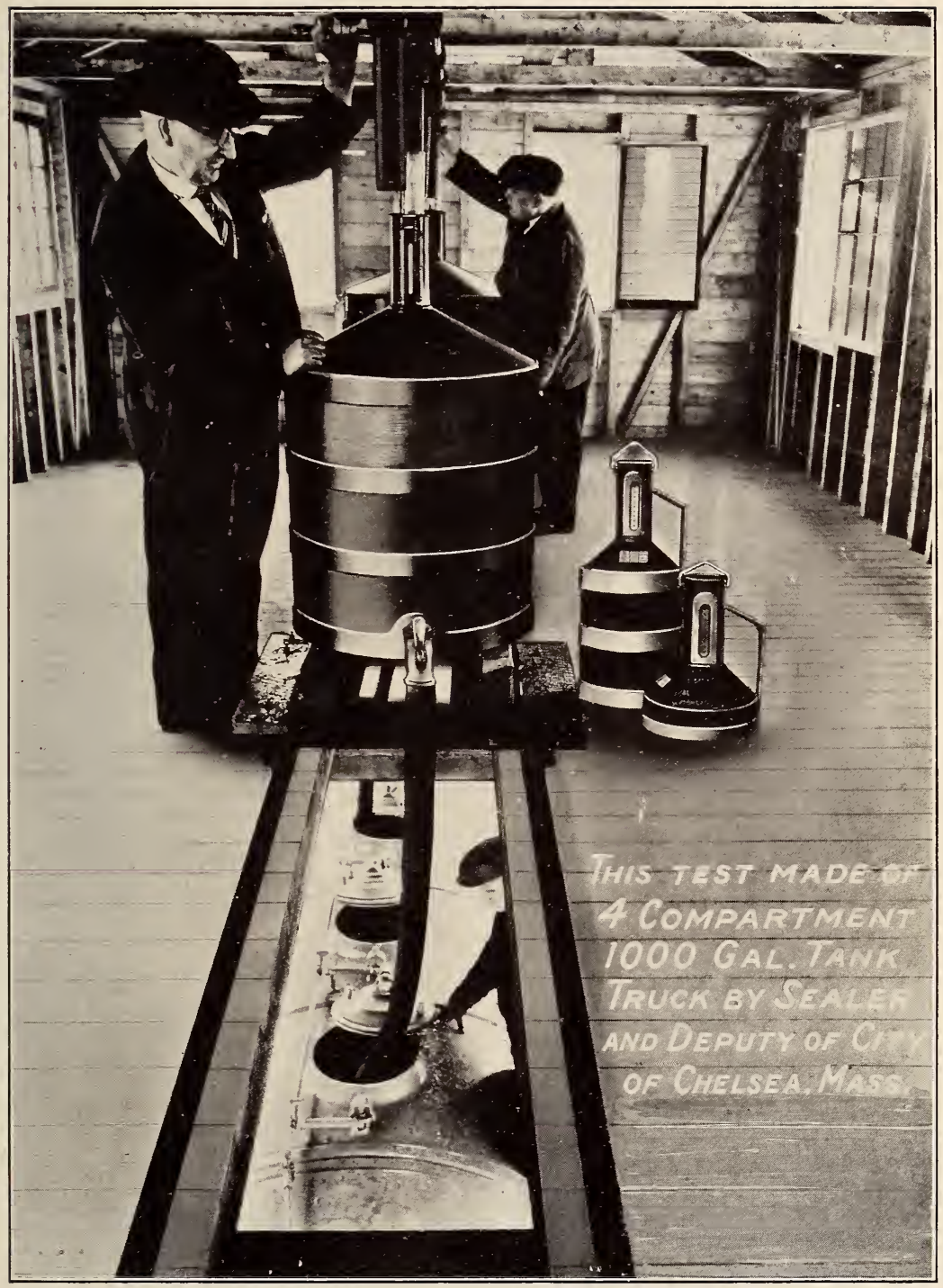

FIgURE 13.-Calibrating a vehicle tank by means of large-capacity measures, in the city of Chelsea, Mass. 

full 50-gallon test measures are also emptied; then from the other 100 -gallons there are drawn off two 5-gallon measures through a regular hose spigot attached to the side of the 100-gallon measure, and the remainder, or 90 gallons, is emptied in the compartment. Finally it is a very simple matter to ascertain the capacity by utilizing as much of the remaining 10 gallons as is necessary to fill up the compartment to within 1 per cent of its total content. We require this 1 per cent of space below the top of the shell in each compartment for expansion.

We found that it was necessary to require that the lines of the several compartments which had valves, be closed, because a number of surprise inspections made on tank vehicles which had previously been calibrated, demonstrated that they were filled with the valves closed (and the lines empty), although they had been calibrated open and full. It seems that the driver took advantage of this amount by filling the compartments to the indicated marker which we seal, but with all valves closed. Driving up to the delivery point he would show the customer that the tanks were full to said indicator; upon delivery the quantity of each compartment would be short by an amount representing the capacity of the delivery line. In order to obviate this condition, which existed despite the apparent cooperation of the oil companies, our office insists that all valves, if any, be closed, and our calibrations are made accordingly.

With the use of these two large-capacity measures, operated by one inspector of weights and measures and one laborer assistant, we are now enabled to handle from 5,000 to 6,000 gallons per day of seven hours. This may not appear to be very fast as compared with another record to which I have the privilege of inviting your attention; however, this is the first time any calibration has been done in a regular way in the city of Baltimore; and, as it is necessary in most every instance to make permanent markers for the tank vehicle under test, and to bore holes, insert indicating rods, and seal same, we consider it creditable. Of course, in subsequent inspections this element of time will be eliminated and much faster speed can be made.

The sealer of weights and measures in Chelsea, Mass., is using the same method as I have described, varied somewhat only in minor detail. Here the two test tanks of 100 gallons and 50 gallons each are mounted on movable trucks or dollies which slide along an opening directly over the compartments of the tank vehicles under test. The figures furnished me by that official show that the average time to fill both test tanks is $11 / 2$ minutes and the average time to drain both test tanks is $11 / 2$ minutes, making a total of 3 minutes to handle 150 gallons; the total time for continuous filling and draining a 1,000-gallon tank truck is given at 45 minutes. They are able to make this very speedy time for the reason that they have a 2-inch fill pipe with five outlets to accommodate any position as the test tank is moved along the track.

In our plar both tanks are stationary, and up to date we have been able to utilize only a $11 / 4$-inch fill pipe; the best time we have been able to make in filling and emptying a 100-gallon and 50-gallon measure is five minutes. However, this speed, of course, is dependent entirely upon the size of the fill pipe and the water pressure, and is subiect to improvement accordingly. 
Where a department is limited in funds we feel that we can recommend this system as being very satisfactory under general conditions, and also very economical, as the cost of both the 100-gallon and the 50-gallon can is just a trifle over $\$ 100$ each. The method which we are using for the calibrating of vehicle tanks by these largecapacity measures has met with the approval of the oil companies operating in our city. While in some instances we have been compelled to reduce the former calibrated quantities which had been ascertained either by the 5-gallon bucket method or with gage sticks, yet in other instances we have increased the quantity because of inaccuracies which naturally developed with the use of these two methods. Several of the oil companies are using meters, but only to a limited extent; they generally confine their use to the measurement from their wholesale storage into the tank vehicle. Naturally the filling stations and consumers are pleased with this work.

If there are any questions pertaining to our method of calibrating which I may have overlooked, I shall be very glad to endeavor to answer them. I thank you.

(During the presentation of this paper Mr. Griffith illustrated by means of lantern slides a number of the measures and installations described.)

CITATION BY WEIGHTS AND MIEASURES OFFICIALS OF IMPORTANT COURT DECISIONS IN THEIR JURISDICTIONS

Mr. Griffith. Mrr. Chairman, I have a decision I would like to refer to.

In the report made by me at the last meeting of this conference, it was mentioned that in pending litigation involving a milk bottle maufactured to hold only 7 ounces, and used for the sale of a product known as "chocolate milk," the case would probably be heard by the court of the city of Baltimore in time for a report at this session.

I wish to advise that this case was in the nature of an injunction requested by the dairy using these 7 -ounce milk bottles, to prevent the city of Baltimore and the division of weights and measures from interfering with its business by prohibiting the use of these 7 -ounce milk bottles.

I have here a printed opinion of the Hon. Judge Frank, of the supreme bench of Baltimore, affecting this case, which is too long to read at this time, but, briefly, I may say the decision of the court was as follows:

That the injunction prayed for would not be granted, but that the bill would be retained in court; if the city of Baltimore was able to produce evidence that this 7-ounce milk bottle was being used for the sale of milk, further intervention by the court would ensue; also that the 7 -ounce bottles in question might be continued in use for the sale of "chocolate milk," provided the type used conform with a later model, and the commodity and the contents be clearly indicated and legibly blown in the glass of the bottle.

I wish to comment on this decision by saying that while apparently the city of Baltimore was unable to prevent the use of this 7 -ounce milk bottle entirely, yet the expression of the court clearly indicates the sympathy of the bench with the efforts of weights and measures supervision in eliminating the perpetration of fraud in the 
premises under consideration. The burden of proof, however, imposed upon the city in securing the evidence of actual use of these 7 -ounce milk bottles for the sale of milk, is very impractical with the insufficient force of inspectors available-a condition usual with departments of weights and measures throughout the country. Nevertheless, it is hoped that our office may be able to produce such evidence within a reasonable time, during which this bill is being retained sub cura by the court.

\section{ANNOUNCEMENTS}

Mr. Holвrooк. Mr. Chairman, may I make an announcement at this time? At the opening session the secretary was directed to send flower's to William F. Cluett, of Chicago, together with a message from the conference. Flowers have been sent, accompanied by the following message :

The National Conference on Weights and Measures was exceedingly regretful at the opening of its meeting to learn that ill health made it impracticable for you to attend this year. We were at once instructed to advise you that you were sorely missed at the meeting, and the conference sends its warmest regards and best wishes for your speedy recovery.

George K. Burgess, President.

F. S. HoLbRook, Secretary.

National Conference on Weights and Measures.

I have a wire from $\mathrm{H}$. A. Webster, of New Hampshire, reading as follows:

F. S. HoLbRook,

CoNcord, N. H., June 3, 1930.

Secretary, National Conference on Weights and Measures,

Bureau of Standards, Washington, D. C.

Regret exceedingly circumstances prevent my attending conference. Cordial greetings to the members. Provencher, inspector of Manchester, is only New Hampshire representative this year. Would report that department has maintained its standard of accomplishments, stressing particularly the matter of liquid-measuring devices. Warm regards to you, Doctor Burgess, and $\mathrm{Mr}$. Smith. Renewed assurance of my appreciation of your cooperation.

H. A. WEBSTER, Commissioner.

(At this point it was moved and seconded that the conference adjourn; the question was taken, and the motion was agreed to.)

(Thereupon, at $4.07 \mathrm{p}$. m., the conference adjourned to meet at 9.30 o'clock a. m., Friday, June 6, 1930.) 


\section{SEVENTH SESSION (MORNING OF FRIDAY, JUNE $6,1930)$}

The conference reassembled at 9.32 o'clock a. m., at the Washington Hotel, Dr. George K. Burgess, president, in the chair.

\section{REPORT OF COMMITTEE ON SPECIFICATIONS AND TOLERANCES ON MODIFICATION OF VARIOUS CODES, PRESENTED BY $F$. $S$. HOLBROOK, CHAIRIMAN}

Your Committee on Specifications and Tolerances report for your consideration certain minor amendments in various codes, which appear to the committee to be necessary to be made at this time. The text of these recommendations was placed in your hands several days ago.

First, it is proposed to amend specification No. 7 under the heading "Scales-General Specifications," reading as follows:

7. When plates or caps are used to limit the longitudinal motion of a knifeedge, the parts of such plates or caps which are liable to come into contact with the knife-edge shall be smooth and at least as hard as the knife-edge. The parts of the knife-edge liable to come into contact with these plates or caps shall be so formed that the friction between them is reduced to a minimum.

by striking out the present language and substituting in lieu thereof, the following:

7. All scales shall be so designed and constructed that at all points at uhich a moving part of the mechanism may come into contact with another part of the mechanism in the course of ordinary usage, frictional effects will be reduced to a minimum through the agency of suitable antifriction elements; opposing surfaces and points shall be properly shaped, finished, and hardened to accomplish the result required.

The former specification, while intended to provide for antifriction devices, was extremely limited in its requirement. It applied only to devices which were intended to limit the longitudinal motion of the knife-edge, such as plates or caps, and to the parts of the knifeedge liable to come into contact with these. This is not at all a complete specification in relation to antifriction devices, and, therefore, it has been amplified in the manner suggested in order that it may be more general in its application.

The Chairman. Is it your pleasure that these should be acted on separately? If so, we will consider this item, as read by the secretary. Are there any comments or discussion?

(A motion was made and seconded that the amended, specification be adopted, the question was taken, and the motion was agreed to.)

Mr. Holbrook. It is proposed that under the heading "ScalesGeneral Specifications" a specification be added to be numbered $23 \mathrm{c}$ and to read as follows:

23c. All scales shall be of such design, construction, and materials that they may reasonably be expected to withstand ordinary usage without impairment of their accuracy or the correct functioning of their operating or indicating parts.

A specification similar in purport to this is already included in many of our later codes. Upon investigation it was found that it 
was not included in this earlier code which was adopted in the original instance, I think about 1913. Certainly it is obvious that this specification should be complied with, and we have had some difficulty in purchase specifications on account of its omission. Therefore, it is suggested that it be incorporated in the specifications at the present time.

(A motion was made and seconded that the specification be adopted, the question was taken, and the motion was agreed to.)

Mr. Holbroor. It is proposed that the first sentence of specification No. 25 under the heading "Scales-General Specifications," reading as follows: "25. All scales shall be maintained in balance," be amended to read as follows:

25. All scales shall be provided with a mechanical device or other means by which the balance condition may be adjusted, and all scales shall be maintained in balance.

While we formerly required that scales should be maintained in balance, we did not require a balancing means, which we think is essential. It is intended that the definitions will remain as they appear in the present specification.

Mr. Neale. Mr. Chairman, I just wonder if the committee means to say "by which the balance condition may be adjusted"? I think it is a question of means. I do not know whether you can adjust a balance condition. I think you may change a condition and bring about a condition of balance.

Mr. Holbrook. It seems to me that you do not adjust the means. I think you manipulate the means in order to secure the condition. Perhaps the word "secured " might be better than "adjusted," or" it may be that the word "adjusted" is all right. I would think the adjustment of the condition was to be obtained by the manipulation of the means. The meaning of it is obvious.

The Chatruras. You do not make a formal amendment?

Mr. Neale. No; I just offered it for the consideration of the committee.

Mr. Holвroок. The committee will give it consideration.

The Chammax. You have heard the proposal on item No. 25.

Mr. Meredith. Is the motion on the word "secured" for "adjusted"?

The Chammax. The gentleman did not offer an amendment, so the question is upon the amendment as proposed by the committee.

(A motion was made and seconded that the amendment be adopted, the question was taken, and the motion was agreed to.)

Mr. Holbrook. It is proposed that specification No. 8, under the heading "Liquid-Measuring Devices," be amended by adding the following words at the end of the third paragraph-

and that in lieu of the maximum rate the words "full flow" or similar and suitable words may be used--

to make this portion of the specification read as follows:

* * * all such meters shall be legibly marked to show the maximum discharge rates under normal conditions of installation and the minimum discharge rates and the maximum working pressures for which they are intended. to be used: Provided, however, That the value of the minimum rate snall not be greater than 7 gallons per minute, and that in lieu of the maximum rate the words "full flow" or similar and suitable vords may be used. 
It has been urged that when a liquid meter is marked as having a maximum discharge rate of, for instance, 20 gallons per minute, the manufacturer may have produced a device which under certain installation conditions will accurately deliver 20 gallons per minute; yet, in the field, when the installation conditions are somewhat different from those normally encountered, a somewhat less amount may actually be delivered by the meter operating at full flow-16 or 18 gallons per minute, perhaps. Some difficulty has been encountered as a result. The buyer of the device-seeing 20 gallons per minute marked upon the meter-is said sometimes to demand that 20 gallons per minute be realized in his installation, regardless of the conditions encountered. The words now suggested require that the meter be correct at the full flow which can be obtained with the pumping means in use and with the outlet valve wide open. To the committee, it appears that such a statement on the meter is just as satisfactory from a weights and measures standpoint as the "maximum discharge rate" statement in terms of gallons per minute; therefore we recommend the change that has been proposed.

(It was moved and seconded that this amendment be adopted, the question was taken, and the motion was agreed to.)

Mr. HoLBRook. There are two additional proposals which were decided upon so late that we did not have the opportunity of including them in the mimeographed copy of this report which was placed in your hands a day or two ago. These amendments are under the heading "Lubricating-Oil Bottles."

Specification No. 2 for Lubricating-Oil Bottles reads as follows:

The overall heights of bottles of the various capacities shall not be greater than the values shown in the following table:

\begin{tabular}{|c|c|}
\hline Capacity of bottle & $\underset{\text { height }}{\text { Maximum }}$ \\
\hline $\begin{array}{l}2 \text { quarts } \\
1 \text { quart } \\
1 \text { pint }\end{array}$ & $\begin{array}{l}123 / 4 \text { inches. } \\
101 / 2 \text { inches. } \\
81 \frac{1}{4} \text { inches. }\end{array}$ \\
\hline
\end{tabular}

In specification No. 5, referring to the attached spout, it is provided that if a spout be attached to these lubricating-oil bottles this shall not be over 6 inches in length, measured from the point of contact with the top of the bottle to the tip of the spout.

Very shortly after the adjournment of the conference which adopted these requirements it was found that bottles were being placed upon the market in which the bottle and the spout were integral-where the metal spout was permanently. attached to the bottle or the bottle was so shaped as to include a glass spout. It seerned that such a bottle might properly be as tall as the combined heights allowed for the bottle and for the spout when these were separate elements.

In view of the fact that Handbook M85 of the Bureau of Standards was just about to be published, the committee added the following note to the maximum-height requirement, and this was printed in the handbook: 
CommitTex NotE.-Bottles are now being developed and produced in which the bottle and the spout are integral; for instance, a metal top may be permanently attached to the bottle, or the bottle may be so shaped as to include a glass spout. In such cases it seems that compliance with these specifications will be substantially secured when the over-all height of the bottle and the permanently attached spout, or the over-all height of a bottle blown integral with the spout, does not exceed the height specified in this table, plus 6 inches which is the figure given in specification No. 5 as the allowable length of a detachable spout.

Obviously, that was only an interpretation of the specification by the committee, and we desire at this time to have the conference consider that matter. Therefore the committee is now recommending to the conference that a note be added to specification No. 2 specifying the maximum height of lubricating-oil bottles, as follows:

NoTE.-When the bottle and the spout are integral-as, for instance, when a metal top is permanently attached to the bottle or a bottle is so shaped as to include a glass spout-this specification shall be construed to be complied with when the over-all height of the bottle and the permanently attached spout, or the over-all height of a bottle blown integral with the spout, does not exceed the height specified in this table, plus 6 inches.

As we see it, that simply makes the bottle having a permanently attached spout comply with the same requirement as the bottle to which a 6 -inch spout is attached.

(A motion was made and seconded that the amendment be adopted, the question was taken, and the motion was agreed to.)

Mr. Holbrook. The next amendment is made necessary by the amendment which you have just adopted.

In specification No. 4 it is provided that the graduation line shall be placed so that there is at least one-fourth inch between it and the bottom of the metal spout when this is screwed firmly into place. Obviously these metal tops which are permanently attached to the bottle and the glass spouts which are integral with the bottle will not be screwed into place. We, therefore, suggest the insertion of the clause "or otherwise securely attached," at the end of the third sentence in specification No. 4, to make the specification read as follows:

4. Bottles shall be provided with a clearly defined graduation line blown or otherwise clearly and permanently marked in or on the bottle, and extending at least halfway around it, which indicates the correct capacity, and with the words "Fill to line" or a similar and suitable inscription clearly and permanently marked in or on the bottle and clearly referable to this graduation line. This line shall in no case be more than 0.10 inch in width and the bottom edge of the line shall define the top of the meniscus of the water which is used in the test of the bottle. This graduation line shall be placed so that it is at least one-fourth inch below the bottom of any metal top when this is firmly screwed into place or otherwise securely attached. The capacity of that portion of the bottle above the bottom of the graduation line shall be at least 3 cubio inches.

(A motion was made and seconded that the amendment be adopted, the question was taken, and the motion was agreed to.)

Mr. Holbrook. That concludes the report.

The Chatrman. The next paper on the program is The Use and Abuse of Person-Weighing Scales, by Carl E. Dartt, president Columbia Scale Co. You will remember that we had a paper last 
year by Mr. Roberts on Coin-Controlled Person-Weighing Scales. This time we will hear from the manufacturer of such scales.

\section{THE USE AND ABUSE OF PERSON-WEIGHING SCALES}

By Cart E. Dartt, President Columbia scale Co.

Mr. Chairman and gentlemen of the conference, at the request of F. S. Holbrook, secretary of the conference, I have prepared a paper on person-weighing scales. I note the title, "The Use and Abuse of Person-Weighing Scales," but in discussing this subject I would like to add one more word, "inaccuracy," as I have heard more about that word than any other since I have been associated with the scale business.

The person-weighing scale, taken as a class and allowing exemption to only two or three out of the dozen of makes and models found on the streets and in stores to-day, has earned for itself a unique distinction among American mechanical devices. It is, in all probability, the only mechanical derice which after thirty-odd years of experiment and development is less efficient than when it was introduced. In making this statement, you will understand, I am considering the person weigher as a "scale," and to this assemblage the word "scale" means an instrument for exact weighing.

The old beam scale, penny controlled, which was among the earliest of the weight sellers to make its appearance, was, in the main, honest and accurate and entitled to be classed as a scale in all that the word implies. It did its full duty as a scale, but as a penny getter it was more or less of a failure for the reason that only a small percentage of the public knew how to operate it. To the manufacturer and operators this was a serious drawback, for their concern was chiefly with the pennies, and in the era of development which followed, the penny feature was the one which occupied practically all of the attention of everyone concerned.

One after another a long line of hybrid devices followed each other into the market and in almost all of these the giving of accurate weight had been subordinated to some "catch-penny" feature designed to increase the intake. In fact, the new "penny machine," as it had come to be called, had strayed so far afield from the parent scale family that in some States the departments having to do with the control of weights and measures were uncertain whether or not these hybrid machines came witnin their jurisdiction. So we see that starting with the old beam scale, which was a good weigher but not much of a penny catcher, we progressed to the modern penny weighing machine, which is a real good penny catcher but not much good as a weigher.

For a number of years the penny weighing machine was goodnaturedly accepted by the American public as one of the standard jokes. Even the most optimistic of those who filled these machines with pennies did not expect to get their correct weight, but looked on the machine as a sort of an amusement device and got their penny's worth in laughing at its inaccuracies, fortunes, trying to get their penny back, and what have you.

And then gradually the American Nation became weight conscious. The health campaigns of the insurance companies and the life estension institutes and the new system of combating human ills by pre- 
ventative rather than curative methods, taught the public that weight is of great importance in the scheme of health conservation. Immediately Mr. and Mrs. General Public became interested in their weight and, inasmuch as few homes are equipped with scales, they naturally turned to the penny weighers for their information. Right here the attitude of the public toward the penny scale underwent an abrupt change. People wanted to know their weight and their correct weight. When they failed to get it they began to protest. Complaints went to the sealers and the newspapers about the inaccuracies of scales. In many cities the newspapers sent out reporters to investigate and a flood of publicity unfavorable to the penny scale resulted. It has had its effect and the end is not yet.

* $*$ * * * * * * * * *

The person-weighing scale is also sometimes used as a merchandise scale in drug stores, as the druggist may be equipped only with a small scale; if a scale is needed of larger capacity, the druggist naturally turns to his person weigher, and it is, therefore, very essential that the accuracy of the person weigher should compare favorably with other types of merchandise scales.

Very naturally the question arises as to what can really be demanded of the penny scale in the way of accuracy. Also whether or not it is entitled to special leniency from the governing powers by reason of its coming in direct contact with the public-and sometimes a malicious public when the small boy is considered.

That the penny scale has a hard battle to maintain its integrity there is no question, but when a hard battle is in prospect it is folly to send a weakling to the combat. As a consequence would it be too much to demand that any scale which is to be tolerated as a public weigher must be first of all an honest and well-constructed piece of precision machinery capable of indicating exact weight? And starting with such a scale it would be hard to understand why it should be granted a greater variance tolerance than is conceded to the merchandise scale. The ideal.arrangement, to my mind, would be to consider that in the life of the person-weighing penny scale there can be only two honest conditions. Either it must be operating and weighing correctly or else, if wrecked by some malicious abuse, not operating at all.

To bring about such a standard in penny weighers, it would seem advisable that all States pass such laws as will bring the personweighing scale under the same restriction and supervision as the merchandise scale, and to make these laws apply to all these scales in use.

In the State of New Jersey a law was passed in May, 1926, which required all new types of person-weighing scales to be approved by the State department of weights and measures. It is my understanding that any scale which was on the market prior to that date can be operated in the State of New Jersey, providing, of course, that it can be sealed. It would seem to me that if the scales manufactured prior to 1926 do not come up to the present standard, the manufacturers should be given a reasonable time to make the necessary corrections and if they do not do so, they should not have the privilege of selling or operating this type of scale. If such legislation 
should be passed, it would not be long before the person-weighing scale would be rated as high as other types of scales and the public could get what they are entitled to, and what they should haveaccurate weight.

\section{DISCUSSION OF ABOYE PAPER}

The Chatrutar. Is there any discussion of the paper?

Mr. Schwartz. I might say, Mr. Chairman, for the benefit of the gentleman, that in New Jersey we had a situation that was somewhat similar to the several instances he offered-illustrations as to changes in indicated weight. In Atlantic County and Atlantic City, there are a large number of person-weighing machines. One morning some years ago, in Atlantic City, I started out right after breakfast to make a cursory inspection of some of these scales. From Atlantic Avenue to the Boardwalk my weight increased and decreased from one-half to 4 pounds on different scales. The only satisfaction I got out of it was that sometimes the scale told my fortune. The weights did not seem to jibe at all. So we started a campaign on person-weighing machines, and rounded them up. Where they were not accurate we put placards reading " condemned" in red letters 8 inches high, together with a statement that the scales could not be used until readjusted and repaired. That was pasted over the face of the scale so that it gave the public warning that that scale was out of order. It did not take long before the personweighing machine companies had their mechanics along the line, but the placards could not be removed until after we had tested and passed on the scales. And of course that took some time. They had to use a pail of hot water, a scraper, and a brush to get the sign off the scales. Finally we passed that regulation that Mr. Dartt mentioned in his paper. We gave particular attention to those scales and practically made them come up as near as possible to the commodity-weighing machine.

One thing that caused a lot of difficulty was that people did not take into consideration the importance of a person-weighing machine. We had complaints from physicians who had patients with tuberculosis who were taking treatment. Such a patient would weigh himself on a person-weighing machine and find his weight to be 130 pounds, for instance. Then later another would register 128 pounds. Now, an increase in weight is all right, but when a scale gave a weight lower than he had formerly received he would feel that he had lost weight, with the result that that would retard his recovery, and he would not get along as well as he should have. It was a nervous strain on the patient, and he would get downhearted at the thought that he was not gaining as he should. That is one of the most serious objections to the person-weighing machine.

\section{IOG RUIES}

By A. W. Conwin, Sealer of Weights and Ileasures, County of Allegany, X. Y.

Mr. President and gentlemen of the conference, in the sale of saw logs it is often desirable to sell the logs by board-foot measurement before the logs are sawed into lumber. The board foot is the common 
unit of measurement of lumber and represents a section of board 1 foot square by 1 inch thick. For this purpose a scale or rule is used, called a log rule. By measuring the diameter and length and making proper allowance for defects, the number of board feet in the $\log$ is determined, and by this measurement payment is made. This system is also used for estimating the quantity of standing timber.

Fortunately there are at the present time a number of reliable authorities on this subject, and most of the information given in this paper will be quoted from them. If one had the mathematical inclination and the time, it would, no doubt, be interesting to delve into the mysteries of log-rule construction, whether by formula, by chart, or by mill tally. This, however, is not essential. The important feature is whether the rule in question actually shows the content of the $\log$ and is fair to both the seller and the buyer.

In sections where lumbering is carried on, the weights and measures official is often called upon to scale $\log$ s and to settle disputes arising over the measurement, or "scaling" as it is usually called. This trouble has often been found to be caused by log rules that show widely different readings, the seller using one and the buyer another. This is not surprising when it is considered that there are at least 57 varieties of the $\log$ rule in this country, every one showing a different result. Certainly here is a good opportunity for standardization. Of all these different rules the one most inaccurate, the most unfair to the seller of the smaller logs (which constitute most of the logs sold to-day), is the rule in most common use in the State of New York, known as the Doyle log rule. This statement applies as well to many other States where inaccurate log rules are in use, and in a number the Doyle is even fixed by law as the State standard. In contrast to this, several States, especially where lumbering is more extensively carried on, have in use very accurate rules, many of which have been adopted as part of the State law. In referring to the Doyle rule it is intended to include, in a general way, other inaccurate rules to whatever extent the inaccuracy exists.

In an effort to correct the unfairness in the use of $\log$ rules in New York State the legislature has recently enacted a law which will be in effect July 1, 1930, fixing the "International 1/4-inch kerf $\log$ rule" as the standard of that State.

Comparison of some of the more common log rules

\begin{tabular}{|c|c|c|}
\hline Log rule & $\begin{array}{l}\text { Log } 12 \text { feet } \\
\text { long, } 12 \\
\text { inches in } \\
\text { diameter }\end{array}$ & $\begin{array}{l}\text { Log } 16 \text { feet } \\
\text { long, } 8 \\
\text { inches in } \\
\text { diameter }\end{array}$ \\
\hline Maine or Holland... & $\begin{array}{r}\text { Boord feet } \\
78\end{array}$ & ${ }_{44}^{\text {Boord feet }}$ \\
\hline Vermont State..... & 72 & ………... \\
\hline Wisconsin State..... & $\begin{array}{r}70 \\
60\end{array}$ & \\
\hline $\begin{array}{l}\text { Scribner } \\
\text { Doyle }\end{array}$ & 59 & 25 \\
\hline Doyle_... & & \\
\hline
\end{tabular}


Comparison of mill scale, Vermont rule, and Doyle rule

[Furnished by the department of weights and measures, State of Vermont]

\begin{tabular}{|c|c|c|c|c|}
\hline Diameter, top end (inches) & $\begin{array}{l}\text { Total num- } \\
\text { ber of logs }\end{array}$ & $\begin{array}{l}\text { Total by } \\
\text { mill scale }\end{array}$ & $\begin{array}{l}\text { Total by } \\
\text { Vermont } \\
\text { rule }\end{array}$ & $\begin{array}{l}\text { Total by } \\
\text { Doyle rule }\end{array}$ \\
\hline${ }^{6} 6$ & $\begin{array}{l}14 \\
25 \\
23 \\
12\end{array}$ & $\begin{array}{r}\text { Board feet } \\
340 \\
989 \\
1,270 \\
1,034\end{array}$ & $\begin{array}{r}\text { Board feet } \\
260 \\
527 \\
1,198 \\
906\end{array}$ & $\begin{array}{r}\text { Board feet } \\
42 \\
197 \\
645 \\
800\end{array}$ \\
\hline
\end{tabular}

NotE. - The mill scale is the amount of lumber made when the log is sawed.

A careful test, under direction of the courts in Texas where logs of given sizes were actually sawed ("Extending a Log Rule," E. A. Braniff, Forestry Quarterly, Vol. VI, 1908, p. 47), showed that for 24 -foot logs sawed by circular saw, the Doyle rule gave an overrun for different diameters, as shown below:

Overrun, Doyle rule, Texas

\begin{tabular}{|c|c|c|c|}
\hline Diameter at small end (inches) & $\begin{array}{l}\text { Actual } \\
\text { output of } \\
\text { sawed } \\
\text { product }\end{array}$ & $\begin{array}{c}\text { Scale, } \\
\text { Doyle } \\
\text { rule }\end{array}$ & Orerrun \\
\hline 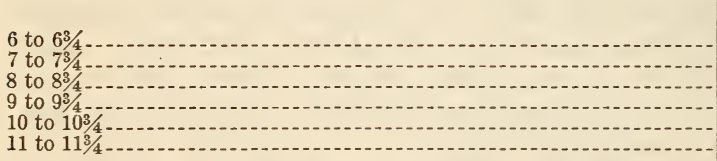 & $\begin{array}{r}\text { Board feet } \\
35 \\
49 \\
61 \\
76 \\
95 \\
112\end{array}$ & $\begin{array}{r}\text { Board feet } \\
6 \\
14 \\
24 \\
37 \\
54 \\
74\end{array}$ & $\begin{array}{r}\text { Per cent } \\
483 \\
250 \\
150 \\
105 \\
76 \\
51\end{array}$ \\
\hline
\end{tabular}

Note.-Overrun is the amount of lumber actually sawed out of the log in excess of the amount determined by log-rule scale.

From mill tests of pine logs sawed with $\frac{3}{16}$-inch kerf, the per cent of overrun was as follows, for 12-foot logs:

Overrun, Doyle rule, Ontario

["Forest Mensuration," H. H. Chapman, M. F.

Diameter of $\log$ at small end (inches)

\begin{tabular}{|r|r|r}
$\begin{array}{c}\text { Actual } \\
\text { output of } \\
\text { inch } \\
\text { lumber }\end{array}$ & $\begin{array}{c}\text { Scale, } \\
\text { Doyle } \\
\text { rule }\end{array}$ & Orerrun \\
\hline Board feet & Board feet & Per cent \\
14 & 3 & 366 \\
30 & 12 & 150 \\
50 & 27 & 85 \\
76 & 48 & 58 \\
108 & 75 & 44 \\
144 & 108 & 33 \\
\hline
\end{tabular}


Comparison of Doyle and International log rules

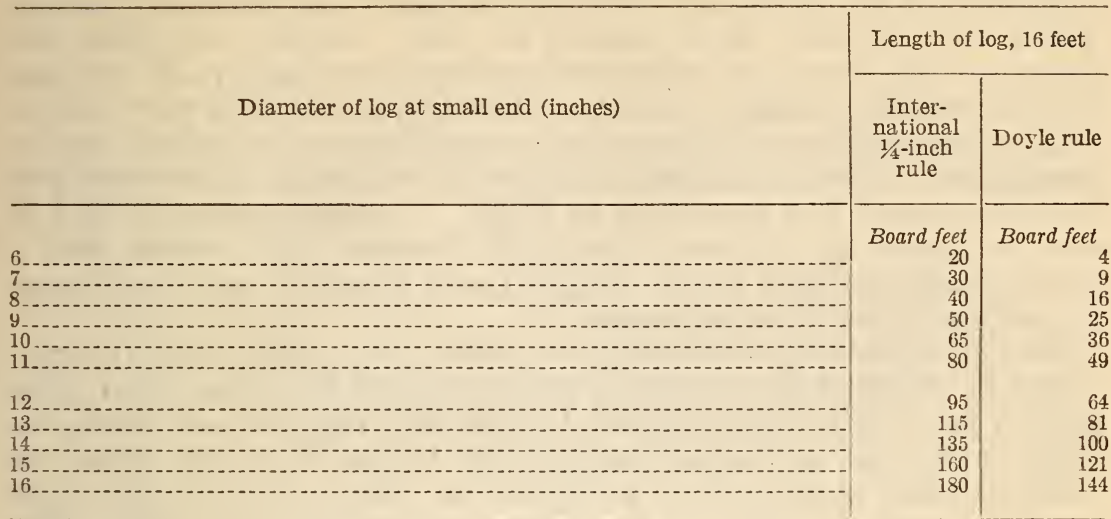

The method of sawing logs has been radically changing through the years. The logs are of a much smaller size than formerly, and more care is used to save all of the lumber. An investigation in the Province of Ontario, Canada, in 1904, showed that the diameter of the average log samed at that time was 12 inches, and that it had decreased 63 per cent in 25 years. The Doyle rule never was an accurate rule, but under the old custom of sawing, and with large logs, it might have been tolerable.

H. C. Belyea, professor of forest engineering, Syracuse University, writes:

The Doyle rule is regarded as one of the most inaccurate rules in existence, although it has a rather wide use. It is a rule which, as we say, has a very large overrun with small diameter logs. * * * It is regarded as an extremely good log rule to buy with, but a poor one to sell by, which explains its general use.

Reading from Forest Mensuration, by H. H. Chapman, M. F., of the Yale School of Forestry:

The wide use of this rule [Doyle] has caused losses of millions of dollars to owners selling logs and standing timber, by improper and defective measurement of contents.

The seller can defend himself against the use of a short measure if the latter is consistent and its per cent of error known. But with a log rule like the Doyle, the per cent of error differs with every scale of logs or stand. of timber and it is practically impossible to determine the actual loss without remeasuring the $\log _{\mathrm{S}}$ by a correct $\log$ rule or tallying the sawed contents.

When the average log ran between 18 and 31 inches, the defects of this rule were not so apparent, and the overrun was not excessive. But as the size of the logs cut grows less with the advent of second growth and closer utilization, the rule becomes impossible. Its continued use in many regions is due largely to the fact that logs are not often bought and sold, but the timber is purchased on the stump and the owner is unaware of his losses. This rule must eventually be superseded either by a more consistent standard or by the rejection of board-foot measure altogether. No owner of small logs or of young standing timber can afford to sell on the basis of a scale or estimate made by the Doyle rule. As it stands, this rule is a serious obstacle to the profitable marketing of second-growth timber, hence to the practice of forestry.

As a rule for universal adoption the Doyle must be rejected because of its glaring inconsistencies and the Doyle-Scribner because it combines the worst features of both rules. 
It is surprising that such inaccurate log rules should be found in such general use in this age of speed, accuracy, and standardization. There are, however, some reasons for this. In the first place the buyer usually selects the rule to be used and naturally picks the rule that shows the smallest readings. The Doyle rule is a very simple rule. Simply subtract 4 from the small diameter, in inches, square one-quarter of the remainder, multiply by the length in feet and you have the board feet according to Doyle. Another reason is that it was published in Scribner's Log and Lumber Book which had a large circulation, was widely accepted as a standard, and was almost the only publication on log rules.

The question might naturally be asked, why should the International be adopted in preference to any one of the other good rules now in use? The International $1 / 4$-inch kerf log rule is a comparatively new rule, developed in 1917 by Judson F. Clark from his International $1 / 8$-inch rule produced in 1900. The 1/8-inch rule would be open to objection for general adoption, as it would overscale the product of most small mills. This rule is considered by authorities to be one of the most accurate log rules, being formed from a scientific formula which is accurate for all sizes and lengths of logs and checks very closely with the actual mill tallies. It does not make the largest scale of any rule, as you have seen by the tables, but is fair to both the buyer and seller. The Federal Land Bank of Springfield, Mass., after an investigation of practically all log rules, found the International by far the most accurate and adopted it for their work covering several States, including New York.

Reading again from Professor Chapmar's Forest Mensuration:

* * * The International $1 / 4$-inch rule is probably as perfect a rule as will ever be required in commerce. This rule is especially raluable for logs below 12 inches and abore 28 inches, in which classes the Scribner rule is defective. There is nothing to be gained by further efforts to construct new perfect log rules.

Professor Belyea, of the Syracuse State School of Forestry, wrote:

It will be rery desirable to have a standard rule adopted in this State * * *. It would certainly be in the interest of the small timber owner who has timber to sell and needs to get erery dollar that he can for the value of his timber, and it would certainly be to his interest to hare a standard $\log$ rule * * *.

I am absolutely persuaded the International rule is the best for use in this State.

When it was first proposed to adopt by law a standard log rule for use in New York State we were informed that it could not be done because the powerful lumber interests would easily prerent its passage. There was some opposition but the fact of the matter was that no man had nerve enough to stand on the floor of the legislature or in the committee room and defend a thing so grossly unfair as the log rules now in use.

The matter was presented to the New York State Farm Bureau Federation, attention being called to the fact that there are $4,000,000$ acres of farm wood lot in the State, the logs from which constitute an important source of revenue. It was recognized that this was in harmony with the popular theme of farm relief, going it one better by giving to the farmers what they were justly entitled to in the measurement of the wood-lot products. In addition to the Farm Bureau Federation, the bill had the support of the American Agri- 
culturist and other farm papers, the Federal Land Bank, the State School of Forestry, the State department of agriculture and markets, and others.

The 1929 legislature first passed the bill, but it was vetoed by the governor because the rule was referred to by name and the formula or chart giving the readings was not included. This change was made, and the bill was repassed by the 1930 legislature and signed by Governor Roosevelt.

This section of the law is as follows:

State of New York, agriculture and market laws, in effect July 1, 1930.

Sec. 193c. StANDARd Log RULe.-The International log rule, based upon $1 / 4$-inch kerf, as expressed in the formula $\left[\left(D^{2} \times 0.22\right)-0.71 D\right] \times 0.904762$ for 4-foot sections ( $D$ represents top diameter of $\log$ in inches; taper allowance, one-half inch per 4 feet lineal), is hereby adopted as the standard log rule for determining the board-foot content of saw logs, and all contracts hereafter entered into for the purchase and sale of saw logs shall be deemed to be made on the basis of such standard rule, unless some other method of measurement is specifically agreed upon.

(During the presentation of this paper Mr. Corwin illustrated by means of lantern slides a number of the matters discussed.)

\section{MOTION IN RELATION TO SPECIAL EXPENDITURE}

Mr. Maroner. Mr. President, may I interrupt the proceedings for just a moment?

The Chamrian. You may, sir.

Mr. Maroney. Mr. President, I move you, sir, that our president and secretary be authorized, if conditions require it, to draw on our treasury in an amount up to the sum of $\$ 500$.

(The motion was seconded.)

The Chamman. You have heard the motion put. Is there any discussion?

Mr. Maroney. Our reason for bringing this motion before you is known to most of you, and I think it would be preferable not to bring in the details and have them go on our record. I know you all have confidence in our executive officers. I know that whatever they do will be what we expect them to do. In view of the fact that certain conditions exist, I hope there will be no discussion on the matter.

The Chairman. I would like to say that it might be well to include the vice presidents in the authorizing authority.

Mr. Maronex. As the vice presidents are miles apart, and, as I said before, you have our confidence, I do not think it necessary. You know, and most of us know, it may be necessary to take action, and quick action; therefore, I limited it to the president and secretary.

Mr. GRIFFrth. I think your suggestion is well taken, but even though distance would not permit of immediate contact, I am quite sure we have the same confidence in our vice presidents as to the action they would take were they included; that will show that all of the officers of this conference are back of the proposition. $I$ ask the mover to accept that amendment.

The Champras. The question is on the motion, as you have heard it, as amended. Are you ready for the motion as amended?

(The question was taken, and the motion was agreed to.)

Mr. Maroney. Thank you, sir. 


\section{SIDE-BEAII AND HIDDEN-WEIGHT SCALES}

By J. C. TInkey, Deputy Sealer of Weights and Measures, State of Ohio

Mr. Chairman, ladies, and gentlemen of the conference, it so happens that I am the only deputy State sealer in Ohio at the present time and there never were more than two. However, we have 88 county sealers and 15 city sealers; with the deputies attached to some of the departments, that gives us a force of about 210 weights and measures officials. In addition, we have commissioners in all of our counties, and their attorneys. Taken as a whole, we have about 725 persons in Ohio directly responsible for the enforcement of the weights and measures law.

This is preliminary to my paper and I hope you will keep it in mind as it shows you how we are organized and how quickly we can put across any new and reasonable regulation.

It is with considerable reluctance that I read this paper. First, because it was requested that our chief, O. J. Bailey, prepare the paper, but when the change was made May 1, placing weights and measures under the division of feeds and fertilizers, we had a new chief, Dr. D. M. Odaffer, who recently requested me to prepare the paper; consequently my time was limited to do justice to such a vital subject.

Second, I had previously informed Mr. Bailey that to change a long-established custom and eliminate scales that could, when in proper order, do correct weighing, was not quite the right thing to do, and if the conference desires to attempt the complete elimination in the near future of this type of scale, I am frank to say that I will not be a party to such an arrangement.

Third, I am more reluctant because there is a vital need of better control of such devices when used in weighing to the customer, and I am fearful that with its many angles for discussion $T$ will not be able to make my points clear in the short time allotted. However, if it will place the matter before you in a way that will court your serious attention and bring it before the conference committee, I will feel that I have at least done my duty, whatever the outcome may be.

I have read what transpired upon this subject at the twenty-second conference and am in accord with the views put forth, but it showed me that it is a very serious debatable question. I have learned that Illinois, Indiana, Michigan, and Minnesota have discussed this question at their conferences, so it is not a new matter.

Ohio laws and specifications are such that the matter could be controlled without any action of this conference. However, we have gone as far as we care to go until we know just what, if anything, this conference will do, as we desire to comply as nearly as possible with your wishes, and believe in standardization and uniformity. It is our belief that with the full cooperation of the manufacturers, dealers, and sealers splendid results will be secured. However, unless a definite date be set for compliance, and unless certain further instructions to sealers be agreed upon and be uniform over the United States, we can not hope for the best results. 
On September 20, 1929, circular No. 3 was mailed from the Ohio State department, addressed to pump, oil, scale, and grocery companies, and to sealers. The third and fourth paragraphs read as follows:

We wish particularly to call the attention of scale manufacturers and merchants to the requirements of Book 10, pages 7, 28 to 32, 91 to 94, 114 to 118 . These are not new laws or regulations as they were adopted by the department more than six years ago. However, a condition has arisen within the past two years which makes enforcement necessary.

The above references refer to scales of the type under discussion.

If scale and pump manufacturers would place with the dealers only those scales and pumps which comply with the State specifications, and if dealers, on the other hand, would use only those that are allowed in the manner designated by the sealers, and replace obsolete equipment as soon as possible with equipment that does comply, conditions would be much better and everyone more nearly satisfied.

At the annual Ohio sealers' convention, held last December, a resolution was passed, requesting the State sealer to make further regulations necessary to handle this scale situation and set a date of compliance. On January 20, 1930, a circular was ready for distribution, but was withheld because we then learned that the matter would be brought up again at Washington, and we desired to comply with the further wishes of this conference. However, in order to acquaint you with the thoughts we had in mind so that you may have the benefit of any points of special interest, and to show you how the whole matter now stands in Ohio, we are concluding our paper by giving you the full text of the proposed circular as follows:

Circular No. -

Columbus, Oнio, January 20, 1930.

To Scale Manufacturers, Dealers, and Sealers:

GENTLEMEN : In our circular No. 3 of September 20, 1929, paragraphs 3 and 4. we called to your attention certain requirements that were to be enforced. To be more specific, one of the things to be corrected is the use of scales not properly constructed or marked and with beams or added weights that are not in view of the customer; therefore in violation of section $7965-1$, page 7 , book 10 ; specifications 2 , page $91 ; 24$, page $94 ; 8$ and 10 , page 114 ; and general instructions, pages 170 and 176 .

In addition to the above laws and regulations, and in order to expedite matters so that uniformity of enforcement will be accomplished, the following rules and regulations are adopted:

No. 1. On and after July 1, 1930, counter scales shall be set on a solid counter, with the reading of the weight of the commodity within 3 feet from the front of the counter, and at a clear angle of vision to the weigher and the customer.

Nотв.-Scales setting crosswise on end of counter may meet the above requirement.

No. 2. Counter scales in use previous to above date will be considered old scales and classed as $\mathbf{A}$ and $\mathbf{B}$.

Class $\mathrm{A}$ are scales with hidden or added weights used when weighing more than 10 pounds.

Class $\mathbf{B}$ are scales with hidden or added weights used when weighing less than 10 pounds.

No. 3. Class A scales shall meet requirements of class B by July 1, 1930, and No. 1 by January 1, 1931.

Class $B$ scales shall meet requirements of No. 1 by July 1, 1930, and previous thereto may be set crosswise of counter at any suitable place provided they are securely fastened to the counter. 
No. 4. Suspension or any other type of scale, when used for weighing to the customer, shall meet the specifications applicable thereto and be governed as class $B$.

Explaxation.- "Counter scale" means any scale used upon a counter when weighing in the-presence of the customer.

"Counter" means any suitable place of installation where scale is intended to be used for weighing to the customer.

Very truly yours,

PerRy L. Greer,

Director of Agriculture and State Sealer.

O. J. BAIIEY, Chief of Division.

J. C. TINKEY,

Deputy State Sealer.

You will especially note that we did not have in mind to entirely eliminate this type of scale, but to try to secure the cooperation of the manufacturers and dealers to the end that by January 1, 1931, no scale of this type would be used when weighing to the customer except when located in the proper manner. W'e have explained to the dealers that it is certainly unfair to their employees, as well as to their customers, to use a scale that slows up the work of selling merchandise accurately in not providing the proper view of the transaction to both the buyer and seller. We are ready to proceed along this line, submitted for your consideration, unless you can show us a better way. I thank you.

\section{STANDARDIZATION ACTIVITIES OF THE NATIONAL SCALE MEN'S ASSOCIATION}

By M. J. J. HAhrisor, Chairman Committee on Specifications, National Scale Men's Association

Last year, through the medium of a paper presented at the trrentysecond meeting of this organization, the attention of the National Conference on Weights and Measures was, I believe for the first time, formally called to the activities of the National Scale Men's Association. At that meeting the conference was told of the preparation and adoption by the association of a code of specifications for the repair of heary-capacity scales, and the conference took formal cognizance of the matter to the extent of adopting a resolution expressing commendation and extending cooperation and moral support.

It is now my privilege to acquaint you with some of the further activities of the National Scale Men's Association, and especially to tell you of certain of the association's outstanding accomplishments during the past year.

In the first place, the code of specifications just referred to, for repair of heary-capacity scales, was slightly revised. I do not want to take the time of this meeting with details, but those of you who are interested may refer to the February and May, 1930, issues of the Scale Journal for a complete list of revisions and the substance thereof.

Of the items of new work, I think possibly the first to be mentioned here is the preparation and indorsement of a code of specifications for light industrial-service track scales.

As you gentlemen are already aware, there are several thousand track scales in present service in the United States. A goodly number of these are owned and operated by railways, and are used pri- 
marily for determining weights for the purpose of assessing transportation charges. The remainder, and incidentally the larger number, are owned and operated by individual shippers and receivers of carload freight. These are used primarily for determining weights of commodities bought and sold, and such weights are principally used as a basis for settlement between buyer and seller, and also, under certain conditions, for determining transportation charges.

There is no essential difference in the accuracy required in a track scale by reason of its ownership or principal use, with the exception, however, that scales used for weighing grain are, as a trade requirement, somewhat more accurate than other scales are required to be. On the other hand, there are several track-scale sizes and capacities which, for the past 10 years, have been recognized as being standard. These sizes and capacities were agreed to in 1920 by a joint committee representing several interests, and since that time the manufacturers of scales have very largely confined their output of 4-section track scales to those sizes and capacities.

When the code of specifications just referred to, generally identified as "Bureau of Standards Circular No. 83," was promulgated, it was the thought of the joint committee that, notwithstanding the fact that the specifications described a series of scales designed primarily for railway service, they would be acceptable to the industries also. That the committee's view was at least partially correct is apparently proved by the general adherence to the specifications by the railways for new installations, and by the large number of "specification scales" purchased and installed by industries since 1920.

However, there are many shippers of carload freight in the United States who never handle their materials in larger quantities than would be contained in a conventional 100,000-pound capacity freight car. In fact, in many cases, even so large a car as one of 100,000 pounds capacity would rarely, if ever, be seen. The specifications contained in Circular No. 83 contemplated as a minimum a somewhat heavier loading than this, and, for this reason, it began to be urged that a lighter-type scale would be economically advantageous.

Now, of course, as long as the industry had no scale to start with, and simply took the position of declining to pay out the amount of money that a standard scale would cost, the National Scale Men's Association had absolutely no interest in the matter. The association certainly was not in the business of selling scales and had nothing to gain or lose, one way or the other.

However, in many cases the shipper already had a track scale in operation. It might be obsolete-it might be sadly deficient-it might be entirely inadequate for the service to which it was subjected-it might have the habit of breaking down so often as to make it a nuisance. But it might have a nicely polished and impressive weighbeam, and to the owner it was his scale. Any suggestion or recommendation that he throw it on the junk pile and spend several thousand dollars for a new scale might be as welcome to his ears as the whir of a rattlesnake's alarm, and the inspector who had the temerity to advance such'a suggestion might find the business end of the rattlesnake pointed his way. In short, the practical 
result was the perpetuation of a large number of obsolete and woefully inadequate track scales, and to a serious extent this was hindering the efforts of those who were trying to maintain a satisfactory degree of weighing efficiency.

This, then, was a situation in which the National Scale Men's Association could not help but be vitally interested, and in 1929 the association adopted a resolution which, boiled down, favored the admission to standardization of additional sizes of track scales. The publication of this action resulted in considerable impetus being given to the proposition of preparing formal specifications for a lighter-type track scale, and a joint committee was formed under the sponsorship of the association. The committee prepared a code of Specifications for the Manufacture and Installation of Railway Track Scales for Light Industrial Service, which was indorsed by the association at its 1930 convention, and subsequently indorsed by the engineering division of the American Railway Association and accepted by the manufacturers.

Briefly, the new code adds one item to the series of standard track scales. The specifications were printed in full in the February, 1930, issue of the Scale Journal, and describe a smaller and lighter scale than any contemplated by Circular No. 83-a scale designed to weigh a loaded 100,000-pound capacity freight car of conventional length as a maximum load. By reason of reduction in size and strength the total cost of such a scale, installed complete, is expected to be materially less than the total cost of any Circular No. 83 scale. At the same time it is believed that no characteristic essential to correctness of weights for the service contemplated was sacrificed.

For the purpose of discouraging the purchase of this scale by those who might be attracted by low first cost, regardless of other important considerations, the weighbeam capacity was kept consistent with the supporting strength of the structure and the length of scale was made considerably shorter than the minimum Circular No. 83 length.

What the effect of the introduction of this scale will be remains to be seen. The facts that less than three months have elapsed since the specifications were adopted and that business conditions have been very quiet during that time have resulted in fewer sales than might reasonably be expected during a corresponding period, say, a year from now. The committee believed it had the correct answer to its problem, and time alone will prove whether it was right or wrong.

The second accomplishment of the association at its 1930 convention to be mentioned here was the adoption of a code of specifications for test-weight cars for use in testing track scales. These specifications were prepared by a committee of the association and appear in full in the March, 1930, issue of the Scale Journal.

Test-weight cars have existed for many years in one form and another, and for several years it might well be said that they were in a state of development. There had been no particularly definite guide in their design until about 1917, when the American Railway Association promulgated as a part of a general code of rules two paragraphs which outlined certain fundamental requirements. An example of the application of these two paragraphs is seen in the 
Miscellaneous Publications, Bureau of Standards, No. 116

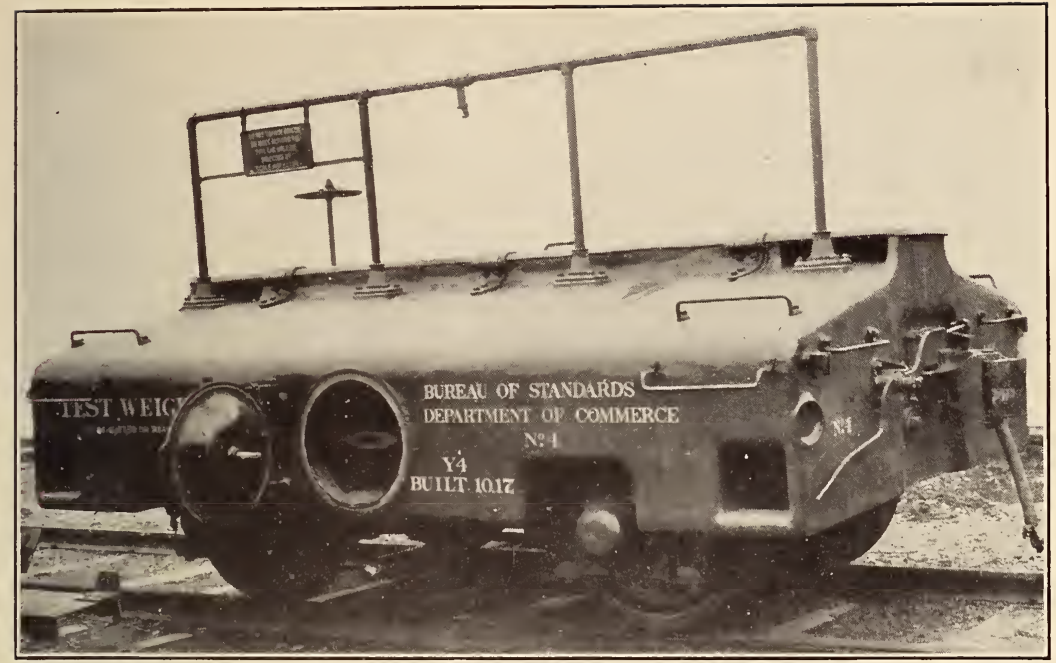

FIgURE 14.-One of the railroad track scale test-weight cars of the National Burcau of Standards

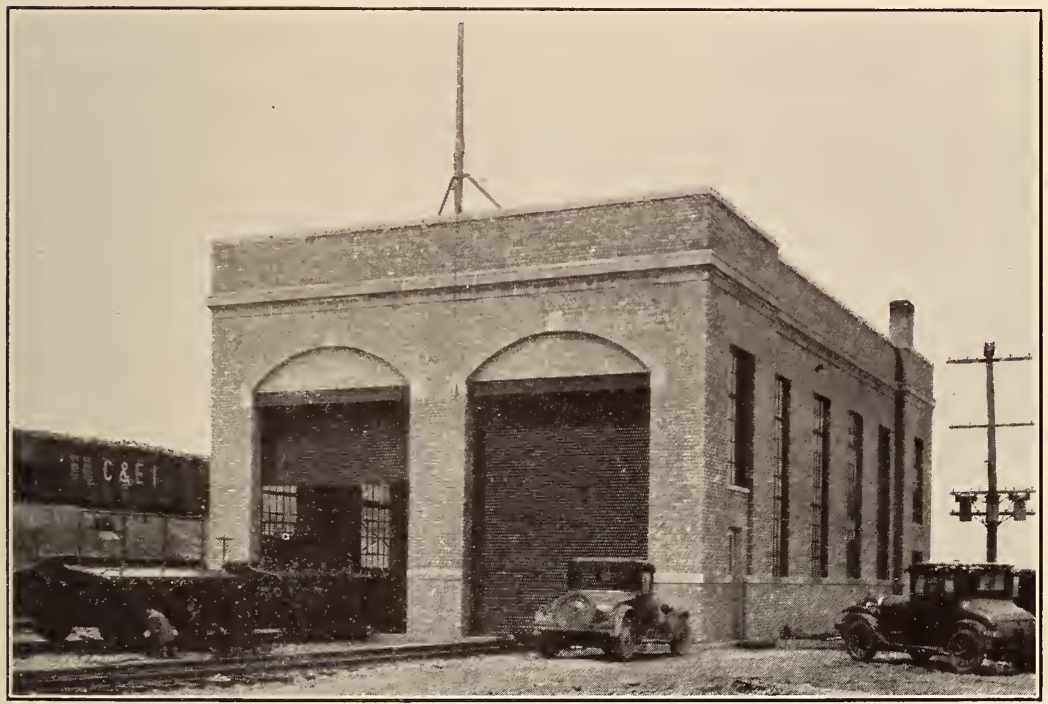

Figure 15.-Master Scale Depot of the National Bureau of Standards, at Clearing, Ill. 

cars operated by the Bureau of Standards. (See fig. 14.) The requirements were:

1. All metal construction. This is obvious in the view shown.

2. Length of wheelbase not to exceed 7 feet. This is taken as the maximum length of wheelbase which can be used satisfactorily in the testing of 4-section track scales. Since car builders always try to get as long a wheelbase as they can, we actually find that 7 feet has come to be the standard length.

3. Load distributed uniformly on wheels. A fairly obvious requirement.

4. No unnecessary ledges or projections likely to catch and hold dirt. Note how this requirement is followed out in the bureau's car, with its smooth surfaces.

5. No unnecessary parts. The car shown is essentially a mass of cast iron on wheels, and the additional parts are merely those which are required by railway operating rules.

6. Strength and durability. The most cursory glance at the car shown gives the impression of ruggedness, and a more detailed inspection would confirm that impression.

7. Surface area reduced as much as possible. Note how compact the bureau's car seems. There is no surplus area.

8. Accessibility of all parts for inspection. A warning to the designer not to hide anything that should be out in sight.

9. Roller or ball bearings, preferably the former. The bureau's car is equipped with roller bearings, and, as a matter of fact, there have been very few test cars built with ball bearings. A properly designed roller or ball bearing aids materially in the use of the cars in the test of a scale, and has the further advantage of helping to keep the weight of the car more constant than would be possible with ordinary -ournal bearings.

I am very glad to be able to show at this time another view (fig. 15), which I feel is particularly appropriate for display at this meeting. This view shows the exterior of the Bureau of Standards Master Scale Depot at Clearing, Ill., just outside the city limits of Chicago. The two test cars seen have just been calibrated on the bureau's plate fulcrum master scale, and are being cleaned and greased before being finally weighed and sent out again. These particular cars happen to be of Pennsylvania Railroad ownership.

In addition to housing the bureau's plate fulcrum master scale, this building contains the laboratory and offices of that section of the bureau which has to do with the testing of large-capacity scales. The depot is also the headquarters of the bureau's three track and master scale testing equipments.

It must be remembered that a test-weight car is actually and essentially a test weight. It is the only form of weight standard that can be used satisfactorily in the testing of commercial track scales. It must weight at least 30,000 pounds, and preferably 40,000 pounds, and it may weigh as much as 100,000 pounds. It must be so designed as to vary as little as possible from its nominal weight during the periods that necessarily intervene between calibrations on a master scale. It must be out in all kinds of weather. It must be hauled around the country on the ends of freight trains and must be shunted through yards. In short, it is necessarily subjected to abuse such as you gen- 
tlemen would never consider permitting in the case of test weights used in the testing of types of scales with which you ordinarily have to deal. And in spite of all this, a test car is essentially a test weight, and the only practical means of insuring the accuracy necessary in the 9,000 or more track scales in the United States.

During the past few years, as the performance characteristics of different types of test-reight cars have become available for comparison, there has been a growing conviction that some distinction should be made as between satisfactory and other types. In other words, it was felt that the general requirements mentioned a few moments ago were all right in themselves but did not go into sufficient detail. It was felt that some organization might well go on record with a detailed description of a satisfactory standard testweight car-in other words, prepare a detailed code of specifications for such cars. As the organization most interested, it was suggested to the National Scale Men's Association that it might well initiate this work, and the result was the preparation and adoption of the specifications referred to.

The National Scale Men's Association naturally based its specifications on the fundamental conception of a test-weight car as a portable test weight-an instrument entitled to the consideration becoming to formal standards of mass. It was felt that it would be much better to base a code of specifications on this conception and later amend them, if necessary, to conform to the views of practical car designers than it would be to ask the car designers to write a code of specifications and then try to amend that code so as to make it describe a formal standard of mass.

At the present time these specifications hare the status of having been adopted only by the National Scale Men's Association. It appears likely that before the specifications attain the desired standing they will also have to be approved by both the engineering and mechanical divisions of the American Railway Association, and steps are now being taken to secure that approval.

The third accomplishment of the National Scale Men's Association at its 1930 convention, and the last to be mentioned here, was the adoption of a standard form for reporting track-scale tests. This form is reproduced in the February, 1930, issue of the Scale Journal. It is the first effort of its kind on the part of the National Scale Men's Association, and sufficient time has not yet elapsed to determine how universal the application of the form is likely to be or whether any changes are likely to be made in it.

In concluding these remarks, I would like to impress on this conference the fact that the National Scale Men's Association exists as a technical organization, interested exclusirely in but one of the matters in which you are interested, and from a somewhat different angle, but carrying its activities in that field a great deal further than would be possible or practicable for the conference. The association will welcome and appreciate the counsel and assistance of the conference in all matters of common interest, and takes this opportunity of again assuring the conference of the sincerity of the association in working toward a successful culmination of mutual lines of effort. 


\section{REPORT OF COMIITTEE ON UNIFORMITY IN WEIGHTS AND MEASURES REQUIREMENTS 7}

Mr. Chairman and members of the conference, we, your committee appointed to consider ways and means for bringing about a more general uniformity in weights and measures regulations and requirements, recommend:

1. That members of the conference continue consideration of the recommendations printed on page 116 of the Report of the TwentySecond National Conference on Weights and Measures.

2. That investigation as to further ways and means of bringing about uniformity in weights and measures regulations and requirements be continued by sending out questionnaires to members of this association in order to make a full report to the conference next year.
(Signed)
J. H. MeEk, Chairman,
V. A. Stovall,
P. D. DUKESHERER,
Philip T. PILON,
Albert B. Smith,
C. P. Smith,
Committee on Uniformity in Weights, and Measures Requirements.

Mr. HolrRook. This report is signed by six of the seven members of the committee. D. E. Fitzgerald, the other member of the committee, is not present at this conference. I understand that Mr. Meek is preparing in the near future to send out certain questionnaires to the members of the conference, and I bespeak for him prompt and adequate replies to the questions that he asks in order that the subject may be fully developed.

(A motion was made and seconded that the report be accepted, the question was taken, and the motion was agreed to.)

\section{GENERAL CONSIDERATION OF SUBJECTS OF INTEREST AND QUESTIONS BROUGHT UP FOR DISCUSSION BY OFFICIALS}

The Chatrunan. The next item is, "General consideration of subjects of interest and questions brought up for discussion by officials." I might add also, by others if they wish. At this time, gentlemen, the opportunity is given to bring before the conference for consideration all subjects of interest which have not been included in the formal program. If any persons have any matters which they wish to bring to the attention of the conference, now is the time to do so.

Mr. Neale. Mr. President, this may not exactly be the proper time, but a friend and strong supporter of this conference, M. D. Ribble, whom you all know, sends greetings from New Mexico.

Mr. SweEner. Mr. Chairman, I wish to call the attention of the conference at this time to a question arising in the testing of taximeters.

Formerly, when the front-wheel drive was employed, we had very little difficulty in proving the correctness of the meters through a bench test, and under Massachusetts requirements a bench test is

7 In the absence of Mr. Meek this report was read to the conference by F. S. Holbrook, secretary. 
required and must be given before a taximeter is affixed to the cab. Now that transmission drives are being employed we find that complications arise owing to the gears necessarily employed with this type of drive, and that a bench test is almost valueless. I have made some experiments in an effort to discover a real solution of this condition. I have made comparisons between various tests and checked the number of revolutions per mile and have discovered that if you accurately measure the circumference of the wheels, it may be possible to prove a meter by a wheel test and not necessarily make a road test. Of course, this raises a very important question, as to whether or not such a test would be deemed a correct one, meeting all legal requirements, because, after all, a rnad test is the best and most logical way to determine the correctness of a meter affixed to the transmission drive.

I feel that it might be the consensus of the conference, if my observations and determinations have proved somewhat the correctness of the method, that the adoption of such a plan upon the part of the sealers would have its approval, particularly in jurisdictions where congestion on the roads is great. I merely mention that at this time in the hope of securing, if possible, a little more cooperation on the part of the manufacturers of taximeters. Perhaps their engineers can devise some method of test that will be correct and save the sealer much work, particularly in those cities where they have an abundance of work to do in that particular line. I feel it would be an especially good thing for the bureau to take this matter up with the manufacturers of taximeters to the end that something definite be brought about to save the sealers a lot of unnecessary work and at the same time satisfy the public in general.

The Chamman. You have brought up an important matter. Is there any comment on Mr. Sweeney's remarks?

Does any other member or guest of the conference desire to bring up any items?

\section{RESIGNATION OF THE TREASURER, GEORGE F. AUSTIN}

The Chairman. Before proceeding to the report of committee on nominations and election of officers, I would like to read a letter I have just received from our treasurer, George F. Austin, whom we know very well indeed, and who has been treasurer of this conference for a number of years. I regret that he finds it necessary to retire from active duty as treasurer.

Bureau of Wetghts and Measures,

1300 Beaubien Street, Detroit, Mich., June 1, 1930.

Mr. President, Officers, and Members of the National Conference on Weights and Measutes Assembled:

In consideration of my decision to retire from weights and measures activities in the near future, I herewith present my resignation as treasurer of the National Conference.

It is with sincere regret that I feel compelled, at this time, to sever my official connection in the National Conference, with which I have been actively associated for more than 20 years, and served as treasurer for the past six years.

I shall remember with pleasure the warm friendships which have come to me through these conferences, and I thank you for the many courtesies and honors conferred upon me.

Yours very truly, 
REPORT OF COMIMITTEE ON NOMINATIONS, PRESENTED BY FRANCIS IMEREDITH, CHAIRIMAN, AND ELECTION OF OFFICERS

Mr. Chairman and gentlemen, your committee on nominations respectfully submits the following names of members of the conference as nominees for officers and members of the executive committee for the ensuing year:

Honorary president, S. W. Stratton; president, George K. Burgess; first vice president, Howard S. Jarrett; second vice president, Albert B. Smith; secretary, F. S. Holbrook; treasurer, George F. Austin, jr.; members of executive committee, all of the officers ex officio, W. F. Cluett, E. J. Crouch, H. N. Davis, C. V. Fickett, Thomas Flaherty, J. H. Foley, William Foster, W. A. Graham, S. T. Griffith, T. F. Mahoney, E. J. Maroney, I. L. Miller, C. R. McFadden, W. A. Payne, B. W. Ragland, G. M. Roberts, W. F. Steinel, V. A. Stovall, H. A. Webster, S. H. Wilson.

(At this point Mr. Meredith assumed the chair.)

The Acting Chairman. Gentlemen, you have heard the report of the committee on nominations. What is your action?

(It was moved and seconded that the report of the committee be accepted, the question was taken, and the motion was agreed to.)

(It was moved and seconded that the nominations be closed, and that the secretary be directed to cast the ballot of the conference for the officers and members of the executive committee, as nominated, the question was taken, and the motion was agreed to.

Accordingly, the secretary cast the ballot of the conference for the officers and members of the executive committee as nominated by the committee on nominations, and they were declared duly elected.)

The Acting Chairman. Doctor Burgess, it gives me the greatest pleasure on behalf of the conference to escort you to the chair.

(Doctor Burgess assumed the chair.)

Doctor Burgess. Gentlemen, as president-elect of this conference I feel in a very great measure the obligation imposed. I also have a great feeling of appreciation that you have sufficient confidence in the Director of the Bureau of Standards to elect him again to this office.

REPORT OF COIMITTEE ON RESOLUTIONS, PRESENTED BY ALBERT B. SIITH, CHAIRMAN

Mr. Chairman and members of the conference, your committee on resolutions has the following resolutions to submit for your consideration:

ADDRESS OF THE ASSISTANT SECRETARY OF COMMERCE, HON. JULIUS KLEIN

Resolved, That the Twenty-third National Conference on Weights and Measures hereby extends to Dr. Julius Klein, Assistant Secretary of Commerce, its thanks and appreciation for his attendance at this conference and for the excellent address delivered thereat.

\section{ADDRESS OF HON. RANDOLPH PERKINS}

Resolved, That we, the delegates to the Twenty-third National Conference on Weights and Measures, extend to the Hon. Randolph Perkins, chairman of the Committee on Coinage, Weights, and Measures, of the House of Repre- 
sentatives of the Congress of the United States, our sincere appreciation and thanks for his very inspiring and instructive address and for his continued interest and assistance in our work.

\section{APPRECIATION TO THE DIRECTOR AND STAFF OF THE BUREAU OF STANDARDS}

Resolved, That the Twenty-third National Conference on Weights and Measures hereby records its sincere and grateful appreciation for the valuable assistance extended by our president, Dr. George K. Burgess, and his able staff, in the interest and guidance of its deliberations.

\section{RETIREMENT OF GEORGE F. AUSTIN}

Whereas Inspector George F. Austin, chief of the weights and measures department of Detroit, has advised the conference of his decision to retire from weights and measures work; and

Whereas Inspector Austin's career has been a long, faithful, and eminently satisfactory one, during which he has furnished a splendid service to the public of his city; and

Whereas Inspector Austin has long been an eminent member of this conference and has served it faithfully as its treasurer: Therefore be it

Resolved, That we, the delegates to this Twenty-third National Conference on Weights and Measures, assembled in Washington, D. C., June 3 to 6, 1930, hereby record our regret at the retirement of Inspector Austin from our councils and wish him enjoyment in his well-merited rest after an arduous career.

\section{CHEMICALLY-TREATED COAL}

Resolved, That we, the delegates to the Twenty-third National Conference on Weights and Measures, assembled at Washington, D. C., June 3 to 6, 1930, declare it to be our opinion at this time that the so-called calcium chloride method of treating coal to make it dustless is not objectionable from a weights and measures standpoint, when by this process the weight of the coal is not increased by more than 30 pounds per ton, and when, in addition, the coal so treated is described on the delivery ticket and billed to the consumer as " chemically treated" coal.

\section{LUBRICATING-OIL EOTTLES NOT COMPLITNG WITH SPECIFICATIONS}

Whereas lubricating-oil dispensing bottles have been placed in service in many parts of the country which far exceed the orer-all height allowable by the lubricating-oil bottle code, and which do not comply with its requirements for capacity markings; and

Whereas exemption from compliance with the code is claimed on the basis that the bottles are containers and not measures, because of the fact that the oil is measured into the bottles and the bottles then sealed; and

Whereas the oil is not delivered to the customer as in the case of other packaged commodities but is transferred to the engine crank case by the station attendant in the usual manner: Therefore be it

Resolved, That it is the opinion of the Twenty-third National Conference on Weights and Measures that these bottles are, in effect, measures, and that they may be readily employed to deceive and to perpetrate fraud upon the customer; and be it further

Resolved, That the conference strongly disapproves these bottles and any others for use in dispensing lubricating oils which do not comply with the code.

\section{MOLDS AND MACHINE-FILLED CARTONS FOR ICE CREAM}

Whereas a general conference of producers, distributors, and users of molds and machine-filled cartons for brick ice cream, held in Washington, D. C., under the auspices of the division of simplified practice of the Bureau of Standards, adopted the following simplified schedule of dimensions for the 2-gallon mold and for machine-filled pint and quart cartons for brick ico cream: 


\section{Two-gallon mold}

\begin{tabular}{|c|c|}
\hline Length & Width \\
\hline
\end{tabular}

Machine-filled cartons

PINT

No. 1 U. S. standard, $3 \frac{3}{16}$ by $3 \frac{1}{2}$ by $2 \frac{11}{16}$ inches

No. 2 U. S. standard, $2 \frac{\tau}{16}$ by $31 / 8$ by $3 \frac{15}{16}$ inches

\section{QUART}

No. 1 U. S. standard, $2 \frac{11}{16}$ by $31 / 2$ by $61 / 4$ inches No. 2 U. S. standard, $2 \frac{7}{16}$ by $3 \frac{1}{8}$ by $7 \frac{1}{4}$ inches

and

Whereas these sizes as adopted are standard sizes and provide an oversize margin to allow for the parchment or waxed-paper liner of the carton; and

Whereas the above action will result in a very desirable simplification of sizes and dimensions: Therefore be it

Resolved, That we, the delegates to the Twenty-third National Conference on Weights and Measures, assembled in Washington, D. C., June 3 to 6, 1930, hereby go on record as approving at this time the sizes mentioned above when used for dispensing ice cream by measure.

\section{APPRECIATION TO MANUFACTURERS DEMONSTRATING GASOLINE METERS}

Whereas much raluable information concerning the construction and operation of meters employed in retailing petroleum products was furnished through the courtesy of the various meter manufacturers: Therefore be it

Resolved, That we, the delegates to the Twenty-third National Conference on Weights and Measures, held in Washington, D. C., June 3 to 6, 1930, do hereby extend our most grateful appreciation for their valuable assistance and for the information disseminated.

\section{COMMENDATION TO FAR WESTERN STATES FOR REPRESENTATION AT CONFERENCE}

Resolved, That the Twenty-third National Conference on Weights and Measures, in assembly met, does hereby thank and especially commend the Far Western States which have sent representatives to this conference, thereby showing their interest in our work; and be it further

Resolved, That a copy of this resolution be sent to the States in question.

GEORGE WASHINGTON BICENTENNIAL

Whereas the Congress of the United States has created a commission to arrange a fitting nation-wide observance of the Two-Hundredth Anniversary of the Birth of George Washington in 1932 ; and

Whereas the commission so created, composed of the President of the United States, the Vice President of the United States, the Speaker of the House of Representatives, four Members of the United States Senate, four Members of the House of Representatives, and eight citizens appointed by the President of the United States, is charged with the duty of planning and directing the celebration; and

Whereas the high purpose of the event is to commemorate the life, character, and achievements of the most illustrious citizen of our Republic and to give every man, woman, and child living under the Stars and Stripes an opportunity to take part in the celebration which will be outstanding in the world's history : and

Whereas the George Washington Bicentennial Commission, desiring the full cooperation of the people in the United States, has extended a most cordial and urgent invitation to our organization to participate in the celebration: Therefore be it 
Resolved, That the Twenty-third National Conference on Weights and Measures does hereby indorse the program of observance of the Two-Hundredth Anniversary of the Birth of George Washington, to take place in 1932, accept with appreciation, the invitation of the George Washington Bicentennial Commission, and pledge this organization to extend earnest cooperation to the United States Commission in all possible ways, so that future generations of American citizens may be inspired to live according to the example and precepts of Washington's exalted life and character, and thus perpetuate the American Republic; and be it further

Resolved, That this resolution be incorporated in the official proceedings of this meeting and that a copy thereof be transmitted to the George Washington Bicentennial Commission, Washington, D. C.

\section{APPRECIATION TO HEADQUARTERS HOTEL MANAGEMENT}

Resolved, That we, the delegates to the Twenty-third National Conference on Weights and Measures, hereby tender our thanks and appreciation to the management of the Hotel Washington, our conference headquarters, for the many courtesies extended the delegates during our meeting.

\section{APPRECIATION TO THE PRESS}

Resolved, That the Twenty-third National Conference on Weights and Measures hereby extends the thanks and appreciation of the Conference to the press of Washington, D. C., for the publicity given its proceedings.

\section{DISCUSSION OF REPORT OF COMMITTEE ON RESOLUTIONS}

The Chairman. You have heard this very interesting report of the committee on resolutions. Do you wish to consider the report of the committee as a whole? What is your pleasure?

Mr. Mahn. Mr. Chairman, I would like to ask Mr. Smith one question in relation to the resolution on ice-cream containers. $\mathrm{He}$ read the figures, but I do not know exactly how those figure out in terms of capacity. We had some trouble in my county with the pint brick which was put into a container which was much larger than the brick itself. Almost everybody thought they were receiving short measure. I do not think the container should be so much oversize as to have that effect.

Mr. Holbrook. I am somewhat familiar with those containers adopted, and I may say, in general, that the 2-gallon mold is 1.1 per cent oversize and the machine-filled cartons are from 1.8 to 3.9 per cent oversize. These cartons were made intentionally large for this reason: When the container is used, a wax-paper lining is normally included, and were the container to be of the exact size, the ice cream contained therein would be short by the rolume occupied by the paper liner. Therefore, these containers were standardized oversize in order to take care of that situation and furnish the proper amount of ice cream to the consumer.

I might also state that these cartons are machine filled. The ice cream is put in the carton when in a semisolid state and is frozen in the carton. That will result in a completely filled package in every case.

(It was moved and seconded that the resolutions presented by the committee be adopted, the question was taken, and the motion was agreed to.) 


\section{RESOLUTION IN RELATION TO STANDARDIZATION ACTIVITIES OF THE NATIONAL SCALE IMEN'S ASSOCIATION}

Mr. HoLвnooк. Mr. Chairman, may I introduce at this time an additional resolution, as follows:

Whereas M. J. J. Harrison, representing the National Scale Men's Associa. tion, has outlined to this conference several standardization activities of that association, and it appears that these activities are both important and meritorious ones: Therefore be it

Resolved, That we, the delegates to the Twenty-third National Conference on Weights and Measures, assembled at Washington, D. C., June 3 to 6, 1930, do hereby extend our congratulations to the National Scale Men's Association upon these accomplishments, record our appreciation of the excellent paper presented, and assure this association of our continued cooperation in activities such as these.

(The resolution was duly adopted.)

\section{REPORT OF THE TREASURER, GEORGE F. AUSTIN 8}

Gentlemen of the conference, I herewith submit my report as treasurer of the National Conference on Weights and Measures for the year ending June 3, 1930.

Receipts :

Balance on hand June 3, 1929

$\$ 306.24$

Received through fees from delegates.

179. 00

Received account of interest

14. 77

Total receipts

500.01

Disbursements :

Flowers in memory of L. A. Fischer $\$ 10.00$

Flowers for Mr. Knauss_____. 10.00

Flowers for A. W. Schwartz_____ 5.00

Cigars, Mr. Knauss, reporting conference.-_-_- 15.00

For special services incident to the conference

Candy for stenographers_._-__- 9.00

Four receipt books_-_- 1.00

Total disbursements___- 57.00

Balance on hand June 3, 1930_- 443.01

Respectfully submitted.

(Signed)

Geo. F. Austin, Treasurer:

(The report was duly accepted.)

Mr. Schwartz. It is very seldom that one sits in a conference and listens to a bill being offered for flowers for himself. This time, I certainly do want to extend my appreciation and thanks to my conference friends for flowers received by me while I was confined to a hospital by illness last July. I am glad to be able to be here, and. I am glad I was able to appreciate the flowers sent.

\section{WREATH IN IVEMORY OF LOUIS A. FISCHER}

Mr. Holвrook. Mr. Chairman, may I state that in accordance with our usual custom Ralph Smith and myself visited Arlington Cemetery just before Memorial Day and placed the tribute of this conference on the grave of our beloved former secretary, Maj. Louis A. Fischer.

${ }^{8}$ In the absence of Geo. F. Austin this report was presented to the conference by George F. Austin, jr. 


\section{MOTION IN RELATION TO EXPENDITURES}

Mr. Schwartz. I move you, sir, that the secretary of the conference be authorized to make the customary expenditures incident to this conference and to draw upon the conference treasurer for the funds so expended.

(The motion was seconded, the question was taken, and the motion was agreed to.)

\section{SUGGESTION AS TO PROGRAII OF TWENTY-FOURTH CONFERENCE}

The Chatrman. This item on the program is one which makes for the success of the next conference. The Chair feels that this conference has been particularly successful and very interesting. We have had some very lively sessions, the opportunity has been given for free discussion, and we have accomplished a great deal. Now is the time for anyone having a suggestion to make for the coming conference to present it. If ideas do not come to you at the present moment, but when you return home you think of any special problems, write in and inform the executive committee.

I would like to ask if the date is satisfactory. I appreciate that you had a warm welcome, but you save money by having it in June rather than at the end of May.

DESIRABILITY OF SPECIFICATIONS AND TOLERANCES FOR PERSON-WEIGHING SCALES

Mr. Holbrook. Mr. Chairman, for the guidance of the Committee on Specifications and Tolerances in their work during the coming year I would like to develop the consensus of the conference as to the advisability of drawing up a code of specifications and tolerances for person-weighing scales to be presented at the next meeting. Is there a demand on the part of the members of the conference for a code of that kind? You will realize that while we have adopted a code for automatic-indicating scales there are many special considerations in relation to person-weighing scales that will make it necessary to adopt a special code, if you desire to have uniformity of regulations pertaining to these scales. Do any of the members desire to express an opinion on the necessity for a code of that kind?

Mr. Foster. I think the suggestion is a very good one. As far as we are concerned, we hare such a code in Massachusetts. It would be very helpful.

Mr. Meredith. I am very much in favor of the idea. In considering devices of this kind, if there is no special code, it very frequently becomes necessary to reach out to other codes and give a good deal of consideration to the question of selecting such specifications therefrom as appear to be applicable. If I understand the suggestion correctly, it would simplify the matter by providing for a code directly concerned with the subject mentioned. I am very much in favor of it.

Mr. A. B. Smrth. Pennsylvania would welcome such action on the part of your committee.

Mr. Sweeney. Mr. President, in view of the fact that it seems to be the consensus of opinion that the various States are in favor of 
such action, I move you, sir, that the Committee on Specifications and Tolerances be instructed to proceed to draw up a code for personweighing machines, to be presented at the next conference to be held in 1931.

(The motion was seconded, the question was taken, and the motion was agreed to.)

Mr. Austin. In connection with the motion to have a code presented on the person-weighing scales, I think it would be a good thing. Unfortunate conditions exist throughout the country in connection with these devices. I know we get calls quite often and we are impressed by conditions as they actually exist. In walking about, your weight may appear to vary from 1 to 5 pounds in 15 minutes. A code ought to be of material benefit.

Mr. Meredith. It occurs to me, Mr. President, to wonder whether or not the subject ought to be enlarged upon somewhat. The term "coin-operated scales" is sometimes used, and this class, while involving person-weighing scales, is somewhat broader, since such a scale might provide some other service. This might be given consideration in connection with the discussion.

Mr. Griffith. Mr. President, if we confined the matter to the coinoperated scale, that would not necessarily cover the person-weighing: machines, because a great many institutions provide these free for the use of their patients, but still I think they might be included in such a code.

The Chairman. Is there any other suggestion for the next conference?

Of course, you understand that the conference is in your own hands. You should suggest what you want to talk about, and you will have an opportunity between now and two months before the next conference to bring in suggestions.

Mr. Hоцввоок. The conference has a very courteous invitation extended by Dr. L. S. Rowe, Director General of the Pan American Union, to visit and examine the Pan American Building. Unfortunately there was no time available to allow us to go there as a body, but I am very sure that the persons in charge would be very happy to receive you singly in the event that you have time this afternoon to visit the building. I may say that it is one of the most beautiful buildings in Washington and will well repay an inspection.

The Charrman. Is there any further business, gentlemen?

(A motion was made and seconded that the conference adjourn, the question was taken, and the motion was agreed to.)

(Thereupon, at 11.45 o'clock a. m., the Twenty-Third National Conference on Weights and Measures adjourned sine die.) 


\section{APPENDIX}

\section{SPECIFICATIONS AND TOLERANCES FOR AUTOMATIC-INDICATING SCALES, ADOPTED BY THE TWENTY-THIRJ NATIONAL CONFER- ENCE ON WEIGHTS AND MEASURES, JUNE 5, 1930}

FOREWORD

The Twenty-Third National Conference on Weights and Measures adopted the following code of specifications and tolerances with the recommendation that it be put into effect not earlier than July 1, 1931.

\section{SPECIFICATIONS AND.TOIERANCES}

Defrinitrox.-An automatic-indicating scale is a scale in which is embodied or to which is attached a self-acting mechanism, the capacity of which may be equal to or less than the total capacity of the scale, through the agency of which the indicated or recorded weights of variable loads may be obtained. This definition is not to be construed to include scales which automatically weigh out commodities in predetermined drafts, such as automatic grain hopper scales, packaging scales, etc. Automatic-indicating scales may be of any one of the following types as classified and defined in these codes of specifications and tolerances: Platform scales (including counter platform scales), counter scales, spring scales, straight-face spring scales, and computing scales. Each automatic-indicating scale shall be subject to the following specifications and to those given under the heading "Scales-General Specifications"; and in addition each scale falling within the definition of any of the classes mentioned above shall be subject to the specifications for such class except in so far as they may be modified by the specifications herein.

SPECIFications.- 1 . The weight dial or reading face, or the indicator, whichever is designed as the stationary element, shall be securely fixed in position; the moving element of the combination shall be securely attached to its operating mechanism: Provided, however, That this specification shall not be construed to prohibit the employment of a movable auxiliary dial or reading face or a movable auxiliary indicator designed to be rotated or moved in reference to a fixed dial or reading face or a fixed indicator, respectively, for the purpose of "balancing out" tare weights.

2. All weight graduations on the dial or reading face shall be clear and distinct and in no case shall their width be less than 0.008 inch nor more than the width of the clear interval between the graduations. Corresponding graduations shall be equal in width. Main graduations shall not be more than 50 per cent wider than subordinate graduations.

3. There shall be a clear interval between the weight graduations on the dial or reading face and this interval shall in no case be less than 0.04 inch. This interval is to be measured between the adjacent 
edges of successive graduations representing the smallest subdivision on the dial or reading face, and along the line of travel of the index of the indicator and shall be maintained whether or not the graduations are "staggered" or arranged alternately; that is, when the graduations are staggered the interval shall be construed to be the space from one graduation to the next consecutive graduation extended, if necessary, to intersect the line of measurement. When the graduations are not parallel the interval shall be construed to be the widest separation of the graduations which is included within the travel of the index of the indicator.

4. The value of the minimum graduation on the dial or reading face shall be construed to be the smallest weight value represented by the travel of the indicator from the center of any graduation to the center of the next succeeding graduation.

5. An automatic-indicating scale shall have a definite and clear zero graduation and shall be susceptible of giving an indication back of the zero graduation sufficient clearly to disclose an out-of-balance condition. These conditions shall be fulfilled whether the entire dial or reading face is graduated or the graduations commence at a fixed load.

6. All weight indicators shall be so designed and constructed that the indications are definite and may be read with precision.

7. All weight indicators shall reach to the graduations; or if the construction is such that the indicator and the dial or reading face are in the same plane then there shall not be a separation of the ends of the graduations and the end of the indicator, of more than 0.04 inch, this distance to be measured along the line of the graduations.

8. When a weight indicator extends along the entire length of a graduation then all that portion of the indicator which may be brought into coincidence with the graduation shall be the same width throughout.

9. The clearance between the index of the indicator and the dial or reading face shall not exceed 0.06 inch in the case of all automaticindicating scales except spring scales not equipped with a device intended to compensate for changes in the elasticity of the springs due to temperature effects; in this latter class of scales this clearance shall not exceed 0.12 inch. Provided, however, That this shall not be construed to prohibit the employment of an additional indicator at a greater distance from the dial or reading face, designed and constructed so as to facilitate the correct positioning of the eye of the observer properly to read the indications of the scale and reduce parallax, when such additional indicator is clearly differentiated from the weight indicator so that it will not be mistaken therefor.

10. When tests are being made with both increasing and decreasing loads on any automatic-indicating scale, the indications on all increasing loads shall be within the normal tolerances provided, and also at any stage of the test the range between corresponding observations for increasing and decreasing loads shall not be greater than the sum of the tolerances in excess and in deficiency for the load in question.

11. An automatic-indicating scale shall be so designed and constructed that the element supplying the counterforce, such as the 
spring, the pendulum, etc., is securely held in adjustment and this element shall not be adjustable from the outside of the scale; that is, a partial disassembling of the scale mechanism or of the housing shall be required to reach any adjustable parts provided. (This specification does not refer to the means commonly provided for adjusting the zero balance condition of a scale.)

ToLERAxCES.-Except on the special tests described above, the tolerances to be allowed on any automatic-indicating scale shall be the tolerances allowed on the class to which the scale under test belongs; these will be found under the specific heading embracing such class. 
